UNIVERSIDADE DE SÃO PAULO

FACULDADE DE FILOSOFIA, LETRAS E CIÊNCIAS HUMANAS

SULAMITA MARIA MATTOS DA COSTA

ROLE PLAYS PARA ANALISAR O "REAL": UM ESTUDO DE REPRESENTAÇÕES COTIDIANAS NA PERSPECTIVA DE FALANTES DE ITALIANO

Versão corrigida

SÃO PAULO

2021 


\title{
ROLE PLAYS PARA ANALISAR O "REAL": UM ESTUDO DE REPRESENTAÇÕES COTIDIANAS NA PERSPECTIVA DE FALANTES DE ITALIANO
}

\begin{abstract}
Dissertação de mestrado apresentada ao programa de PósGraduação em Língua, Literatura, e Cultura Italianas da Faculdade de Filosofia, Letras e Ciências Humanas da Universidade de São Paulo, como parte dos requisitos para obtenção do título de mestra.
\end{abstract}

Orientadora: Prof. Dra. Elisabetta A. R. M. C. Santoro

\section{Versão corrigida}

SÃO PAULO 
Autorizo a reprodução e divulgação total ou parcial deste trabalho, por qualquer meio convencional ou eletrônico, para fins de estudo e pesquisa, desde que citada a fonte. 


\section{ENTREGA DO EXEMPLAR CORRIGIDO DA DISSERTAÇÃO/TESE}

\section{Termo de Ciência e Concordância do (a) orientador (a)}

\section{Nome do (a) aluno (a): $\quad$ Sulamita Maria Mattos da Costa}

Data da defesa: 20/05/2021

Nome do Prof. (a) orientador (a): Elisabetta A. R. M. C. Santoro

Nos termos da legislação vigente, declaro ESTAR CIENTE do conteúdo deste EXEMPLAR CORRIGIDO elaborado em atenção às sugestões dos membros da comissão Julgadora na sessão de defesa do trabalho, manifestando-me plenamente favorável ao seu encaminhamento e publicação no Portal Digital de Teses da USP.

São Paulo, 20/07/2021

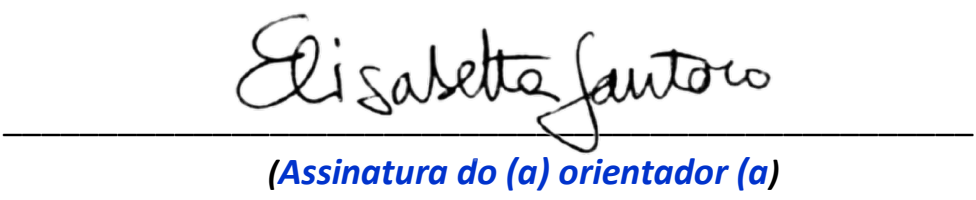




\section{AGRADECIMENTOS}

Poder falar de máscaras e representações cotidianas em um momento em que a sobrevivência humana se dá justamente por meio de rostos mascarados só foi possível graças à colaboração generosa de "indivíduos comuns", que no nosso encontrar de caminhos se tornaram únicos, cada um à sua maneira, encenando majestosamente sua própria máscara.

Agradeço à minha orientadora, especialista em precisão, força e inspiração.

Agradeço à minha família, aos meus amigos e a cada um que, representando a melhor versão de si, me manteve com sonhos vivos todos os dias, por meio de cuidados, orações e cafés.

Agradeço a uma força muito maior do que o mundo, que pode ser chamado por nomes variados, mas que eu chamo de Deus e que em tempos tão difíceis como os atuais me fez entender que ciência e milagre são faces da mesma moeda.

Agradeço também à Capes que, com a concessão da bolsa de estudos, permitiu a realização desta pesquisa. 
Todos os seres humanos são atores, porque agem, e espectadores, porque observam. Somos espect-atores. (Augusto Boal) 


\section{RESUMO}

O role play é uma das principais metodologias de coleta de dados utilizadas nas pesquisas em diferentes áreas relacionadas ao estudo das línguas em uso como a Pragmática linguística. Embora seja muito difundido, questiona-se, com frequência, se e em que medida os dados que resultam dele podem representar situações de comunicação real, uma vez que se trata de "encenações", consideradas distantes da realidade (FÉLIX-BRASDEFER, 2018; GOLATO, 2003). Partindo dessas premissas, o presente estudo propõe analisar, a partir de uma perspectiva interdisciplinar, tanto o processo de elaboração do role play, a encenação, quanto o material linguístico por ele eliciado, utilizando para a observação um referencial teórico composto por teorias desenvolvidas no âmbito das Artes Cênicas e dos estudos linguísticos, mas também na visão sociológica da "vida como representação", proposta por Goffman (1975 [1959]). A pesquisa busca investigar tanto se encenar uma situação dada ou criada pode permitir reproduzir o "real", quanto se há diferenças na percepção da naturalidade e da adequação dessas situações quando avaliadas por "não atores" e atores. As reflexões baseiam-se, por um lado, na afirmação de Erving Goffman (1959), segundo o qual todo ser humano não só é capaz de representar, mas interpreta o tempo todo; por outro, na constatação de que artistas de diferentes vertentes vêm tentando trazer a verossimilhança - ou "traços do real" - para seus espetáculos, inserindo pessoas comuns ("não atores") que interpretam a si mesmos, em um movimento que muito se assemelha a role plays do tipo que foi investigado neste estudo. Foram utilizados role plays gravados por falantes nativos de italiano e, posteriormente, submetidos ao julgamento de outros falantes nativos atores e "não atores", por meio de um judgment test baseado em uma escala Likert, que previa a atribuição de uma pontuação de 1 a 5 para avaliar a naturalidade e a adequação dos role plays com base em oito parâmetros, além de perguntas abertas para que os informantes pudessem incluir observações mais gerais e justificar a pontuação atribuída. $\mathrm{O}$ objetivo era saber como os indivíduos avaliavam as gravações em termos de espontaneidade, verossimilhança e naturalidade e como percebiam a adequação dos role plays comparados com o que consideravam possível no cotidiano de sua língua e cultura. Outra etapa foi o processo de autoavaliação, o qual ocorre quando o próprio falante que participou da realização do role play avalia o seu desempenho, observando se o modo como produziu a interação verbal e desenvolveu as ações corresponde ao que acredita que faria na vida real. $\mathrm{O}$ estudo mostrou que existe uma tendência semelhante na avaliação de "não atores" e atores em considerar naturais e adequados os role play, além de similaridades entre a percepção dos avaliadores e dos participantes que "atuaram" nos role plays e também classificaram suas ações e suas falas como naturais e adequadas.

Palavras-chave: Role play, Pragmática linguística, teoria teatral, língua italiana. 


\begin{abstract}
Role play is one of the main data collection methodologies used in research in different areas related to the study of languages in use such as Pragmatics. Although it is widespread, it is often questioned whether and to what extent the data resulting from it can represent situations of real communication, since it is "enactment", role play is considered distant from reality (FÉLIX-BRASDEFER, 2018; GOLATO, 2003). Based on these premises, the present study proposes to analyze, from an interdisciplinary perspective, both the process of elaborating a role play (the "enactment" itself), and the linguistic material it elicited, using a theoretical framework composed of theories developed within the theatre and performing arts theories and linguistic studies, but also in the sociological view of "life as representation", proposed by Erving Goffman (1975 [1959]). The research aims to investigate if enacting a given or created situation can allow reproducing the "reality", as well as whether there are differences in the perception of the naturalness and adequacy of these situations when evaluated by "non-actors" and actors. The reflections are based, on the one hand, on the statement by Goffman (1959), according to which every human being is not only capable of representing, but interprets all the time; on the other, in the finding that artists of different tendencies have been trying to bring verisimilitude - or "traces of the real" - to their shows, inserting ordinary people ("non-actors") who interpret themselves, in a movement that is very similar to the type of role play that was investigated in this study. Role plays recorded by native Italian speakers were used and subsequently submitted to the judgment of other native speakers, actors and "nonactors", through a judgment test based on a Likert scale, that provided for the assignment of a score from 1 to 5, to assess the naturalness and adequacy of role plays based on eight parameters. In addition, there were open questions so that the informants could include more general observations and justify the assigned scores. The aim was to know how the individuals evaluated the recordings in terms of spontaneity, verisimilitude and naturalness and how they perceived the adequacy of the role plays compared to what they considered possible in the daily life of their language and culture. Another step was the self-assessment process, which occurs when the speakers who participated in the role play evaluate their performance, observing whether the way they produced the verbal interaction and developed the actions corresponds to what they believe they would do in real life. The study showed that there is a similar trend in the evaluation of "non-actors" and actors in considering the role plays natural and adequate. There are also similarities between the perception of the raters and the participants who "acted" in the role plays and also found that their actions and their words were natural and appropriate.
\end{abstract}

Keywords: role play, pragmatics, theatre theories, italian language. 


\begin{abstract}
Il role play è una delle principali metodologie di raccolta di dati utilizzate nella ricerca in diverse aree legate allo studio delle lingue in uso come la pragmatica linguistica. Sebbene sia molto diffuso, ci si chiede spesso se e in che misura i dati che ne derivano possano rappresentare situazioni di comunicazione reale, trattandosi di una "messa in scena", considerata distante dalla realtà (FÉLIX-BRASDEFER, 2018; GOLATO, 2003 ). Sulla base di queste premesse, il presente studio si propone di analizzare, da una prospettiva interdisciplinare, sia il processo di elaborazione del role play (la messa in scena), sia il materiale linguistico che produce, utilizzando per l'osservazione un quadro teorico composto da teorie sviluppate nell'ambito delle teorie del teatro e della performance e degli studi linguistici, ma anche nella visione sociologica della "vita come rappresentazione", proposta da Goffman (1975 [1959]). La ricerca cerca di indagare sia se mettere in scena una situazione data o creata può consentire di riprodurre il "reale", sia se ci sono differenze nella percezione della naturalezza e dell'adeguatezza di queste situazioni quando valutate da "non attori" e attori. Le riflessioni si basano, da un lato, sull'affermazione di Erving Goffman (1959), secondo cui ogni essere umano non solo è capace di rappresentare, ma interpreta sempre; dall'altro, sulla constatazione che artisti di diverse tendenze hanno cercato di portare verosimiglianza - o "tracce del reale" - nei loro spettacoli, inserendo persone comuni ("non attori") che interpretano se stessi, in un movimento che è molto simile ai role plays che sono stati analizzati in questo studio. Sono stati utilizzati role play registrati da madrelingua italiani e successivamente sottoposti al giudizio di altri madrelingua, attori e "non attori", attraverso un judgement test basato su una scala Likert, che prevedeva l'assegnazione di un punteggio da 1 a 5 per valutare la naturalezza e l'adeguatezza dei role play sulla base di otto parametri, oltre a domande aperte in modo che gli informanti potessero includere osservazioni più generali e giustificare il punteggio assegnato. L'obiettivo era sapere come gli individui valutavano le registrazioni in termini di spontaneità, verosimiglianza e naturalezza e come percepivaano l'adeguatezza dei role play rispetto a quanto ritenevano possibile nella vita quotidiana della loro lingua e cultura. Un altro passo è stato il processo di autovalutazione, che si realizza quando il parlante che ha partecipato al role play valuta la sua performance, osservando se il modo in cui ha prodotto l'interazione verbale e sviluppato le azioni corrisponde a ciò che crede che avrebbe fatto nella vita reale. Lo studio ha mostrato che esiste una tendenza simile nella valutazione dei "non attori" e degli attori nel considerare i role play naturali e adeguati, oltre alle somiglianze tra le percezioni dei valutatori e dei partecipanti che "hanno recitato" e anch'essi classificato le loro azioni e le loro parole come naturali e appropriate.
\end{abstract}

Parole chiave: role play, pragmatica, teoria del teatro, lingua italiana. 


\section{LISTA DE FIGURAS}

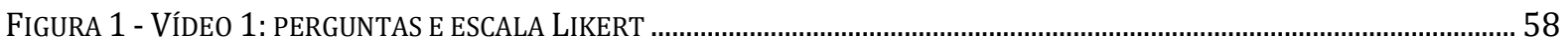

FIGURA 2 - QUESTIONÁRIO FINAL

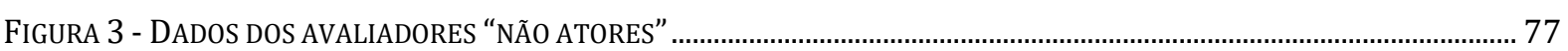

FIGURA 4- DADOS DOS AVALIADORES ATORES ..................................................................................................................... 78

\section{LISTA DE GRÁFICOS}

GRÁFICO 1 - CoMPARAÇ̃̃o DA AVALIAÇ̃̃o DE ATORES E NÃO ATORES EM CADA ROLE PLAY ………………………………….... 90

GRÁFICO 2 - CoRRELAÇ̃̃o DE PEARSON ENTRE TODOS OS PARÂMETROS ............................................................................... 93

GRÁFICO 3 - AVALIAÇ̃̃O DA ESPONTANEIDADE “NÃO ATORES”........................................................................................ 95

GRÁFICO 4 - AVALIAÇÃO DA ESPONTANEIDADE ATORES ....................................................................................................... 95

GRÁFICO 5 - MÉDIAS ESPONTANEIDADE “NÃO ATORES” E ATORES ……............................................................................... 97

GRÁFICO 6 - VEROSSIMILHANÇA "NÃO ATORES" ........................................................................................................... 99

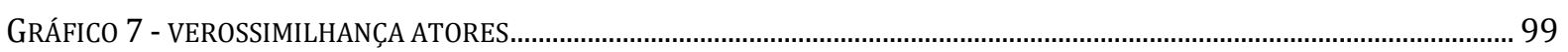

GRÁFICO 8- MÉDIAS VEROSSIMILHANÇA “NÃO ATORES” E ATORES.......................................................................................101

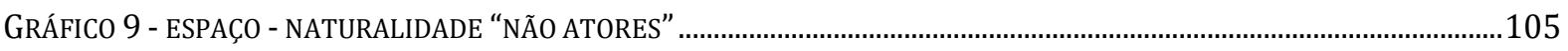

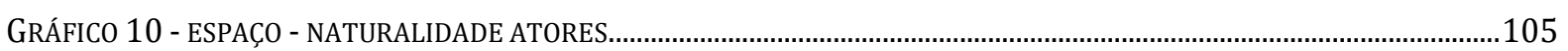

GRÁFICO 11 - MÉdIAS ESPAÇO-NATURALIDADE “NÃO ATORES” E ATORES............................................................................106

GRÁFICO 12 - ESPAÇO - ADEQUAÇ̃̃O “NÃO ATORES” ....................................................................................................108

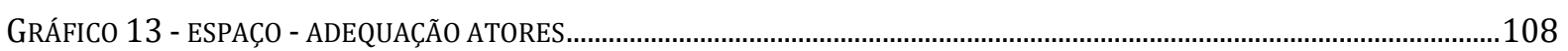

GRÁFICO 14 - MÉDIAS ESPAÇO-NATURALIDADE “NÃO ATORES” E ATORES...........................................................................109

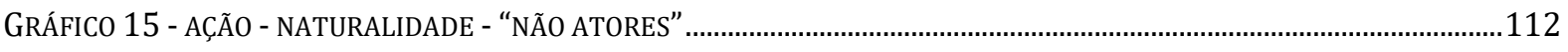

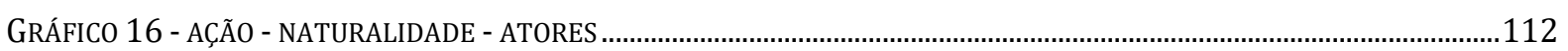

GRÁFICO 17 - MÉDIAS ESPAÇO - NATURALIDADE - "NÃO ATORES” E ATORES ………………….........................................113

GRÁFICO 18 - AÇÃO - ADEQUAÇÃO “NÃO ATORES” .....................................................................................................115

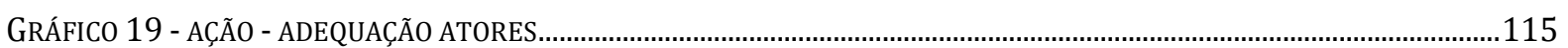

GRÁFICO 20- MÉDIAS AÇÃO - ADEQUAÇÃO “NÃO ATORES” E ATORES..................................................................................116

GRÁFICO 21 - LÍNGUA - NATURALIDADE “NÃO ATORES" ................................................................................................118

GRÁFICO 22 - LÍNGUA - NATURALIDADE ATORES.....................................................................................................118

GRÁFICO 23 - MÉdIAS LÍNGUA - NATURALIDADE “NÃo ATORES” E ATORES ............................................................................120

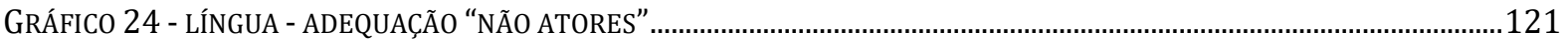

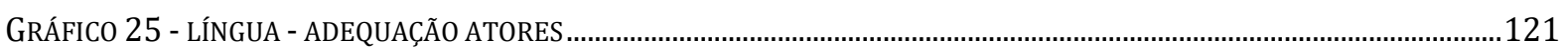

GRÁFICO 26 - MÉdIAS LÍNGUA - ADEQUAÇ̃̃o “NÃO ATORES” E ATORES ..................................................................................122

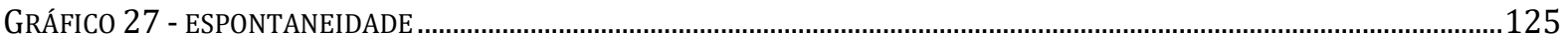

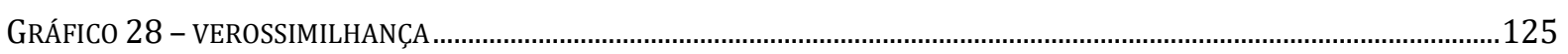

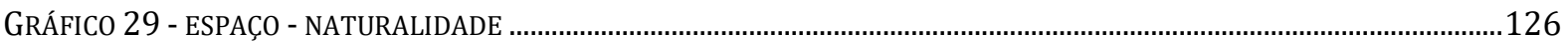

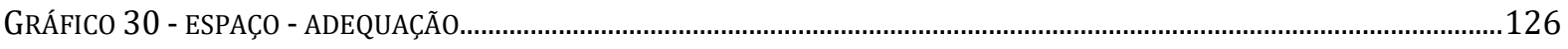

GRÁFICO 31 - AÇÃO - NATURALIDADE ....................................................................................................................................127 


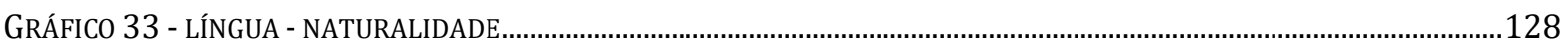

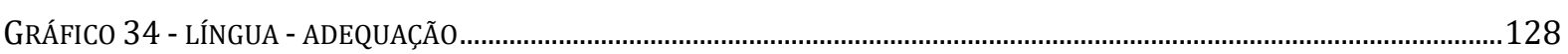

\section{LISTA DE QUADROS}

QUADRO 1 - CLASSIFICAÇÃo DE METODOLOGIAS DE COLETA DE DADOS (VALIDADE INTERNA E EXTERNA).............................20

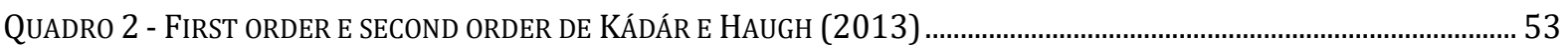

QUADRO 3 - DESCRIÇÃO DE SITUAÇÕES DE BAIXO GRAU DE IMPOSIÇÃO …........................................................................... 54

QUADRO 4 - DESCRIÇÃO DE SITUAÇÕES DE ALTO GRAU DE IMPOSIÇÃO ................................................................................ 54

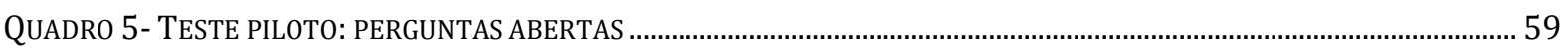

QUADRO 6 - COMPARAÇÃO ENTRE QUESTIONÁRIO PILOTO E QUESTIONÁRIO FINAL ................................................................. 70

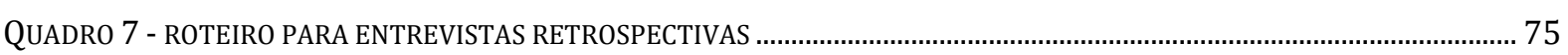

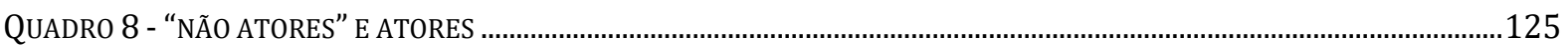

\section{LISTA DE TABELAS}

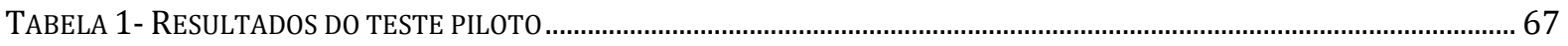

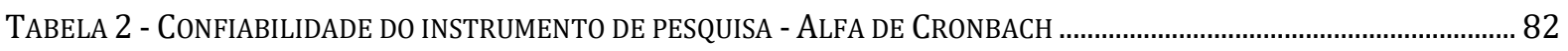

TABELA 3- CORRELAÇ̃̃O ENTRE OS ITENS DO QUESTIONÁRIO ........................................................................................... 82

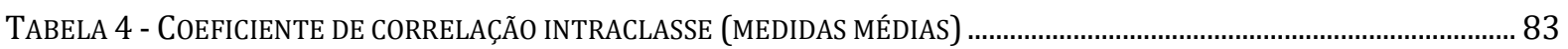

TABELA 5 - RESUltados Do GENERAL LINEAR ModEL (GLM): AVALIADORES E SITUAÇÕES ............................................... 83

TABELA 6- MÉDIA E DESVIO PADRÃO DA AVALIAÇÃO DOS VÍDEOS POR SITUAÇÃO .................................................................. 86

TABELA 7 - COMPARAÇÃO ATOR / “NÃO ATOR” POR PARÂMETRO E SITUAÇÃO........................................................................ 87

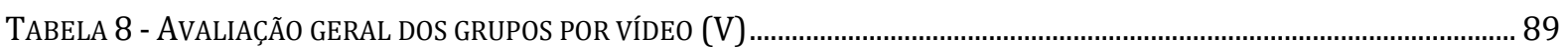

TABELA 9 - MÉDIA GERAL DA PONTUAÇÃO POR PARÂMETRO DE AVALIAÇÃO....................................................................... 92 


\section{SUMÁRIO}

INTRODUÇÃO

1. “LUZ, CÂMERA, AÇÃO!”: O ROLE PLAY SOB MÚLTIPLAS PERSPECTIVAS................................18

1.1 O ROLE PLAY COMO METODOLOGIA DE COLETA DE DADOS: CARACTERÍSTICAS E PROCEDIMENTOS............... 18

1.1.1 A Linguística e a busca por dados naturalísticos ........................................................................23

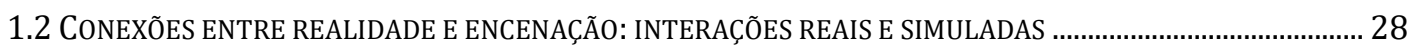

1.2.1 As representações de si e a construção de máscaras cotidianas ...............................................31

1.3 A LÍNGUA NA "REPRESENTAÇ̃̃o DE PAPÉIS": ALGUMAS VOZES DA LINGUíSTICA .......................................... 38

1.4 A VIDA REAL NA ARTE: UM PARALELO ENTRE ROLE PLAY E TÉCNICAS ARTÍ́TICAS........................................ 42

2. DA TEORIA À PERCEPÇÃO DOS FALANTES: A METODOLOGIA DA PESQUISA .........................51

2.10 TESTE PILOTO_.................................................................................................................................. 53

2.1.1 Os role plays selecionados para o teste....................................................................................5

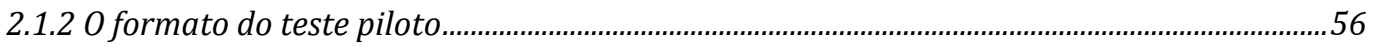

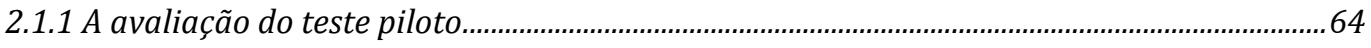

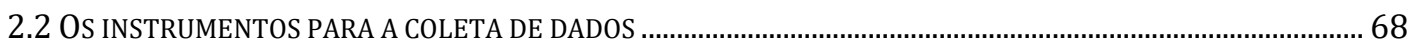

2.2.1 Os questionários de avaliação dos role plays...............................................................................69

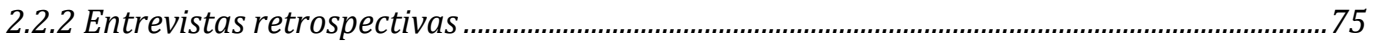

2.3 OS PARTICIPANTES DA PESQUISA: ATORES E “NÃO ATORES” COMO JULGADORES.............................................. 77

2.4 METOdologia DE ANÁLISE: TRATAMENTO ESTATÍSTICO E ANÁLISE QUALITATIVA........................................ 79

3. O PONTO DE VISTA DO FALANTE: ATORES E NÃO ATORES COMO AVALIADORES DE ROLE

PLAYS EM ITALIANO

3.1 A VALIDAÇূ̃̃O DO INSTRUMENTO DE PESQUISA........................................................................................ 81

3.2 “NÃO ATORES” VS. ATORES: A PERCEPÇÃO GERAL DOS DOIS GRUPOS DE AVALIADORES ................................. 83

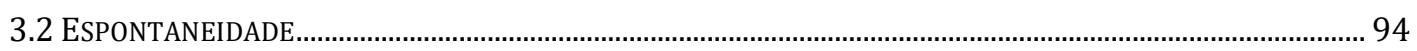

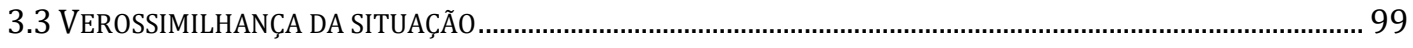

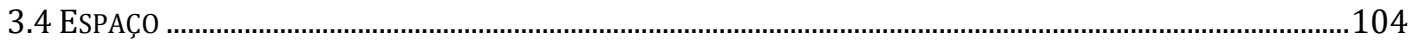

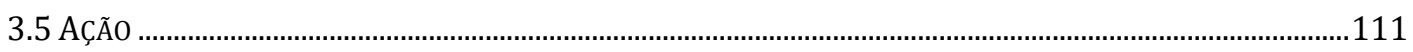

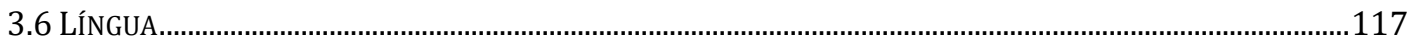

3.7 ROLE PLAYS DE ATORES E DE "NÃO ATORES”: UMA COMPARAÇ̃̃O_.........................................................124

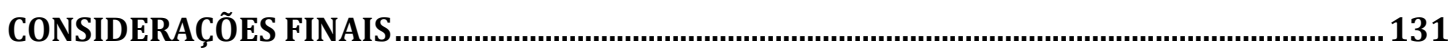

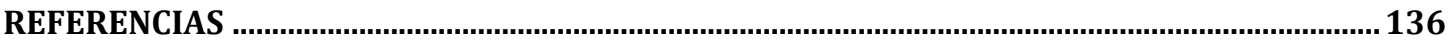

ANEXO I - TRANSCRIÇÃO DOS ROLE PLAYS UTILIZADOS NO QUESTIONÁRIO .......................... 143

ANEXO 2 - TRANSCRIÇÃO DAS ENTREVISTAS RETROSPECTIVAS ……................................. 147

ANEXO 3 - PERGUNTAS E RESPOSTAS DA PARTE ABERTA DO QUESTIONÁRIO FINAL ....... 165 


\section{INTRODUÇÃO}

Não faço nenhuma grande afirmação literária para dizer que a vida social não é nada além de um palco, apenas um pequeno e técnico palco: no qual, profundamente incorporados na natureza da fala, estão os requisitos fundamentais da teatralidade. ${ }^{1}$

[I make no large literary claim that social life is but a stage, only a small technical one: that deeply incorporated into the nature of talk are the fundamental requirements of theatricality.] (GOFFMAN, 1981, p. 4).

O role play (doravante RP) é uma das principais metodologias de coleta de dados utilizadas nas últimas décadas em pesquisas que se propõem a estudar a língua em uso. Porém, questiona-se, com frequência, se e em que medida os dados que resultam dessa metodologia podem ser vistos como "naturalísticos", ou seja, algo que retrate situações de comunicação real e a língua como ela é efetivamente utilizada pelos falantes. Tal questionamento fundamentase, em parte, no fato de RPs serem elaborados a partir da encenação de interações, portanto, da simulação de um comportamento, o que pressuporia, segundo alguns, certo distanciamento da realidade.

A correspondência entre as amostras estudadas em pesquisas de cunho linguístico e o que ocorre na vida real é uma questão essencial para as disciplinas que estudam a língua por meio de dados empíricos. No caso da Pragmática, nascida como disciplina do âmbito da Filosofia da Linguagem, a partir da Teoria dos Atos de Fala de John Langshaw Austin (1962), foi só em uma segunda fase que essa preocupação se tornou relevante. Embora a teoria de Austin conceba a ação como "performada" no momento em que o falante pronuncia determinado tipo de enunciado, os primeiros estudos em Pragmática ainda analisavam a língua com exemplos ad hoc, ou seja, idealizados pelos próprios pesquisadores, de acordo com o que conheciam de comportamentos sociais em situações cotidianas.

Foi quando os linguistas passaram a reconhecer a importância de se investigar o evento da fala do ponto de vista do falante, levando em consideração o momento e o contexto do enunciado, que a questão dos dados empíricos ganhou protagonismo. Com efeito, David Crystal afirma que Pragmática é

o estudo da língua do ponto de vista dos usuários, especialmente em relação às escolhas que fazem, às limitações que encontram usando a língua na interação

\footnotetext{
${ }^{1}$ Exceto onde indicado, todas as traduções dessa dissertação são de nossa autoria.
} 
social e aos efeitos que seu uso da língua provoca nos outros participantes no ato de comunicação.

[the study of language from the point of view of users, especially of the choices they make, the constraints they encounter in using language in social interaction and the effects their use of language has on other participants in the act of communication.] (1997, p. 301)

Coloca-se, então, para os pesquisadores a necessidade de analisar interações, que permitam observar e examinar as "escolhas" dos falantes, as "limitações" das normas sociais e os "efeitos" do que é dito e isso parecia ser possível apenas a partir de amostras de língua, por meio das quais ter acesso ao modo como se fala na realidade.

Com esse fim, foram desenvolvidas metodologias de coleta de dados que, com o aumento do número de pesquisas, passaram a compor uma espécie de tradição, sendo amplamente utilizadas, não só em trabalhos na área da Pragmática, mas em diferentes campos de estudo das línguas interessados a seu "uso", como a Sociolinguística e a Análise da Conversação. Dentre essas metodologias, se firmaram em especial o chamado Discourse Completion Task (DCT) e o RP. Os DCTs são questionários, geralmente escritos, entregues aos participantes com a descrição de uma situação comunicativa a partir da qual eles precisam escrever, no caso dos DCTs escritos, ou falar, quando os DCTs são orais, imaginando o que diriam ou como agiriam na situação apresentada (MACKEY \& GASS, 2005, p. 89). Já nos RPs, os participantes não escrevem, mas interagem e falam, simulando a situação proposta (CROOKALL \& SAUNDERS, 1989). As interações são normalmente gravadas, ou só em áudio ou em áudio e vídeo.

Mesmo apresentando grande contribuição para as pesquisas, permitindo, por exemplo, que os estudos sejam ampliáveis e replicáveis, metodologias dessa natureza encontram ainda certa resistência de parte da comunidade científica. Uma vez que os pesquisadores pretendiam coletar um material, que deveria ser "retirado" de situações reais de comunicação, eles apontam que "metodologias de coleta que eliciam dados (por exemplo, questionários de produção, role plays) não oferecem uma medida real de discurso autêntico e podem resultar em dados, que divergem de modo importante de produções linguísticas em settings naturais” [“(...) elicited data collection methods (e.g. production questionnaires, role plays) do not offer a direct measure of authentic discourse and may result in data which diverge in important ways from language produced in natural settings"'] (BATALLER \& SHIVELY, 2011, p. 16). Seria esse, por exemplo, o caso dos DCTs, nos quais se perdem, inclusive, os traços da oralidade, mas também dos RPs, em que falantes encenam com base em situações pré-determinadas. 
No entanto, é possível pensar que não apenas essas duas metodologias, mas qualquer situação de coleta de dados na qual intervenha um pesquisador não estaria respeitando a premissa da naturalidade. De fato, até mesmo os processos reconhecidos por eliciarem dados de alta validade externa (ditos "naturalísticos"), ou seja, aqueles que pressupõem maior proximidade com a realidade, são incapazes de fornecer material integralmente real, em primeiro lugar, por serem um recorte da realidade escolhido para determinados objetivos de pesquisa. Além disso, em procedimentos de coleta e análise de dados de língua falada, é preciso sempre considerar, por exemplo, a impossível neutralidade do processo de transcrição (OCHS, 1979); ou também o que Labov (1970) chamou de "paradoxo do observador", isto é, o fato de uma presença externa necessariamente exercer influência nos dados coletados. Por isso, segundo Pallotti

(...) a realidade nunca é reproduzida em sua total complexidade fenomenológica, mas o pesquisador sempre intervém ativamente para "pegar" fatias significativas dela para seu próprio projeto de pesquisa.

[(...) la realtà non viene mai riprodotta nella sua totale complessità fenomenologica, ma il ricercatore interviene sempre attivamente per 'prenderne' delle fette significative per il proprio progetto di ricerca.] (2001, p.37)

Se essa afirmação é verdadeira, podemos considerar que qualquer metodologia de coleta de dados necessariamente reduz e transforma a "realidade" e, portanto, que também DCTs e RPs são possibilidades à disposição do pesquisador, já que não alteram esse pressuposto.

No caso dos RPs, há, no entanto, outras críticas ligadas mais especificamente à questão da encenação como processo pelo qual os dados são eliciados. Segundo alguns pesquisadores, tal processo seria um dos principais motivos de divergência entre o material linguístico coletado e a língua "real" (FÉLIX-BRASDEFER, 2018), na medida em que, ao representar uma situação ou um papel criado por outra pessoa (no nosso contexto, o pesquisador), o falante estaria impossibilitado de agir de modo natural e suficientemente autêntico, o que impediria que os dados sejam um recorte adequado da realidade (GOLATO, 2003).

Descreveremos essas críticas com mais detalhes no primeiro capítulo desta dissertação. Agora, apresentamos uma das reflexões que serão centrais no trabalho, a saber, que, curiosamente, se considerarmos áreas de estudo como as Artes Cênicas, encontramos um movimento inverso, com vertentes do Teatro e da Performance que buscam a aproximação com a realidade justamente a partir da encenação e da simulação de ações cotidianas feitas por pessoas comuns, às vezes, chamadas também de "não atores" (BOAL, 2015). O material por 
eles produzido e posteriormente selecionado e organizado pelos artistas transforma-se no próprio espetáculo teatral ou performativo (MENDES, 2017), com a finalidade de "transportar para o palco" o que acontece na realidade. Conceitos provenientes dessas áreas foram utilizados também por Erving Goffman (1975 [1959]), que, mesmo tendo trabalhado em outros campos do saber, analisa as interações humanas do ponto de vista do teatro e afirma que a ação de representar papéis é, na verdade, uma característica própria da vida real. A ideia de que a vida é representação foi ilustrada também por escritores e dramaturgos, entre os quais o italiano Luigi Pirandello, o qual, em um de seus ensaios, escreve:

Todo mundo veste a máscara como pode - a máscara externa. Porque dentro existe outra, que muitas vezes não combina com aquela de fora. E nada é verdade! Verdadeiro o mar, sim, verdadeira a montanha; verdadeira a pedra; verdadeira um fio de grama; mas o homem? Sempre mascarado, involuntariamente, sem saber, daquilo que de boa fé finge ser: bonito, bom, gracioso, generoso, infeliz, etc. etc.

[Ciascuno si racconcia la maschera come può - la maschera esteriore. Perchè dentro poi c'è l'altra, che spesso non s'accorda con quella di fuori. E niente è vero! Vero il mare, sì, vera la montagna; vero il sasso; vero un filo d'erba; ma l'uomo? Sempre mascherato, senza volerlo, senza saperlo, di quella tal cosa ch'egli in buona fede si figura d'essere: bello, buono, grazioso, generoso, infelice, ecc. ecc.] (PIRANDELLO, 2018 [1908] p. 172).

Desse modo o autor evidencia que, em todos os momentos de sua existência, os seres humanos são a soma de diferentes papéis, construídos socialmente. Em outras palavras, na concepção de Pirandello, é só na representação que, de fato, existimos. Sobre essa questão, também nos deteremos no capítulo 1 deste trabalho.

Com base nesses pressupostos, a indagação geral da qual nasce o trabalho aqui apresentado, aplicada, no nosso caso, à língua e à cultura italianas, é a seguinte: se, mesmo na vida real, interagimos uns com os outros por meio da representação ${ }^{2}$ de papéis, não seria um ponto de partida questionável a contraposição entre dados coletados por RPs e dados ditos "naturalísticos"? Se o falante "atua", tanto nas situações reais quanto nas eliciadas, não haveria entre elas mais analogias que diferenças?

Aliás, se a língua eliciada por essa metodologia é vista pelos linguistas não como uma língua "real”, mas como uma encenação, para analisá-la, parece ser imprescindível lançarmos

\footnotetext{
${ }^{2}$ No referencial teórico utilizado, os termos "representação", "encenação" e ainda "simulação", ora aparecem como sinônimos, ora são utilizados de forma diferente (GOFFMAN, 1975 [1959]; CROOKALL \& SAUNDERS, 1989). O presente estudo utilizará os dois primeiros termos como sinônimos, conservando a palavra "simulação" para uma descrição técnica da encenação de uma ação.
} 
o olhar em direção ao que foi dito por aqueles que observaram e colocam em prática justamente a ação de encenar o real. Por isso, propomos aqui um caminho interdisciplinar e buscamos o referencial teórico das Artes Cênicas, comumente não utilizado para analisar RPs elaborados para pesquisas de cunho linguístico.

Embora existam alguns estudos que colocaram em diálogo as Artes Cênicas e a Linguística $^{3}$, nossa busca por trabalhos da mesma natureza do que propomos aqui não obteve resultados, de modo que não temos conhecimento de pesquisas com objetivos semelhantes.

Nossa proposta é unir a perspectiva da "vida como representação", que emerge tanto dos estudos na área das próprias Artes Cênicas, quanto das análises de Goffman (1975 [1959]), à visão da Linguística e, mais especificamente, da Pragmática, por ser um dos campos nos quais a questão da autenticidade dos dados é mais debatida.

A partir da já citada literatura, decidimos, em primeiro lugar, definir algumas categorias operacionais, entre as quais "situação", "espaço", "ação" e "língua". Com base nessas categorias, foi posteriormente elaborado um questionário, enviado eletronicamente a falantes nativos de italiano, aos quais foi pedido que indicassem, em uma seleção de RPs, o grau de naturalidade e/ou de adequação percebidos por eles para cada uma das categorias. Se as encenações são avaliadas pelos falantes nativos como naturais e adequadas, por que elas não seriam também aceitáveis para as pesquisas? Se, do ponto de vista da interação, representam o que falantes nativos consideram "real" e/ou "natural" dentro da sua própria língua e cultura, não seriam esses dados também confiáveis do ponto de vista linguístico?

Tendo em vista que, segundo a literatura, atores teriam um olhar mais treinado para observar a realidade e depois representá-la (BOAL, 2015; GOFFMAN, 1981), consideramos que sua participação, tanto na gravação quanto na avaliação dos RPs, poderia ampliar o propósito da pesquisa, nos oferecendo uma contribuição mais "técnica". Por essa razão, os vídeos escolhidos para o questionário foram gravados por atores e "não atores" e também os avaliadores foram divididos em dois grupos de falantes nativos de italiano, um formado por atores e outro por "não atores".

\footnotetext{
${ }^{3}$ A título de exemplo, podemos citar as dissertações de mestrado de Kamunjin Tanguele "Os atos diretivos nas peças psicológicas de Nelson Rodrigues" (2016), na qual uma peça de Nelson Rodrigues foi analisada na perspectivas da Pragmática linguística, ou de Andrés Esteban Carrasco Rodríguez "De la pragmática lingüística a la pragmática teatral"(2015), na qual se propõe que a Pragmática Linguística pode contribuir com uma montagem teatral mas eficiente na medida em que permite ao diretor maior consciência e controle do que ele quer dizer ao seu público. No âmbito artístico, é possível encontrar obras como a de Marvin Carlson "Performance. Uma introdução crítica" (2010), que explica o modo como a Performance é abordada na Linguística e na Sociologia, e o Dicionário de Teatro de Patrice Pavis (1997) que, em algum dos verbetes, também considera a perspectiva linguística.
} 
Um terceiro grupo de avaliadores foi composto pelos próprios participantes dos vídeos - apenas os "não atores", já que os atores foram informados sobre o tipo de trabalho realizado - que, respondendo em uma entrevista às mesmas perguntas do questionário, avaliaram a naturalidade de suas próprias encenações e a experiência de ter participado das gravações.

As escolhas metodológicas, que ilustraremos no cap. 2, foram feitas, seguindo, inclusive, o que ocorre muitas vezes nos estudos da área da Pragmática, que ao considerar a perspectiva e a percepção do falante externo e do participante (KÁDÁR \& HAUGH, 2013), abrem espaço para que a língua seja analisada a partir de múltiplos prismas.

A hipótese inicial era que, mesmo a partir de encenações e da simulação de ações proposta pela metodologia do RP, pode-se "captar a realidade", permitindo aos pesquisadores a análise de como os falantes se comunicam, na medida em que encenação e realidade não devem ser consideradas como antagonistas, mas como a própria vida.

O objetivo geral do presente estudo é, partindo desse princípio da identidade entre encenação e realidade, verificar se e em que medida atuar em uma situação cotidiana, dada ou "criada" por um pesquisador, permite reproduzir a realidade de como falantes se comunicam.

A pesquisa se organizou seguindo três objetivos específicos. O primeiro deles é o de analisar o modo como falantes nativos de italiano percebem as encenações eliciadas por RPs incluindo a língua utilizada na representação - no que diz respeito à sua naturalidade e adequação, tendo em vista o contexto situacional proposto. O segundo é identificar se e em que medida há convergências e divergências entre a percepção, por parte de falantes nativos, da naturalidade desses vídeos e da adequação dos diferentes aspectos que os compõem, comparando, inclusive, avaliações de atores e "não atores". Já o terceiro objetivo que guiou o estudo é o de procurar detectar, a partir da percepção dos "não atores" que participaram da gravação dos RPs selecionados para a avaliação, a naturalidade e a adequação de suas próprias encenações, buscando também saber deles o que acessaram de suas realidades para realizar as interações filmadas.

A partir disso, foram formuladas três perguntas de pesquisa que nortearam o desenvolvimento do trabalho:

i) De que forma falantes nativos de italiano avaliam a naturalidade e a adequação de RPs gravados em áudio e vídeo, em língua italiana, tendo em vista o contexto situacional proposto e utilizando categorias pré-definidas?

ii) Em que medida varia ou converge e quais aspectos evidencia a forma como falantes nativos atores e não atores percebem a naturalidade e/ou a adequação de uma seleção de RPs e de elementos que os constituem? 
iii) De que maneira os participantes dos RPs percebem e avaliam seu comportamento, ou seja, suas próprias representações e como descrevem, partindo das mesmas categorias utilizadas para os falantes nativos, a experiência de ter realizado as gravações, comparada, inclusive, com sua vida real?

Ao tentar aferir a percepção da naturalidade de RPs e verificar a hipótese acima exposta, buscou-se não só aprofundar as reflexões sobre a metodologia de coleta de dados em questão, mas também contribuir com estudos que analisam especificamente a língua italiana por meio de gravações de falantes nativos e, assim, proporcionar uma análise dos dados já existentes e utilizados em trabalhos sobre essa língua. Os RPs, escolhidos como objeto de análise e submetidos à avaliação, partem do ato de fala do pedido, um dos mais frequentemente estudados pelas complexas relações que cria entre os interlocutores. Trata-se, em todos os casos, de situações cotidianas, que ocorrem em dois ambientes sociais distintos: a casa de outrem e a rua.

Esta dissertação é composta por três capítulos.

No primeiro capítulo, são explicadas as particularidades e os processos de elaboração do RP utilizado como metodologia de coleta de dados em pesquisas desenvolvidas para o estudo da língua em uso. Em seguida, o RP é analisado a partir de um referencial teórico interdisciplinar, que compreende as teorias nascidas nas áreas da Linguística, as teorias e experiências teatrais e performativas e a perspectiva da "vida como representação", postulada por Goffman (1975 [1959], 1981).

No segundo capítulo, é descrita a metodologia escolhida para a realização do trabalho, que é composta por um questionário de percepção (judgement test), com oito RPs de falantes nativos de italiano, "não atores" e atores, e oito parâmetros selecionados para a atribuição de uma pontuação de 1 a 5 (escala Likert) por parte de dois grupos de avaliadores, também divididos entre "não atores" e atores. É descrito o processo de desenvolvimento do teste piloto, sua avaliação e como foi definida a versão definitiva do questionário. São ilustradas também as características da entrevista retrospectiva, realizadas com os quatro participantes "não atores", que gravaram os RPs. Além disso, ainda nessa parte, são especificadas as informações sobre os participantes e sobre a metodologia de análise.

O terceiro e último capítulo é dedicado à apresentação e à discussão dos resultados. Em primeiro lugar, são expostos os dados relativos à validade do instrumento utilizado para a coleta dos dados quantitativos. Por meio de testes estatísticos, foram verificados, por um lado, a 
consistência interna do instrumento e seu uso adequado e, por outro, a correlação entre os critérios escolhidos e sua confiabilidade. Em seguida, há a apresentação da percepção geral dos dois grupos de avaliadores ("não atores" e atores), analisada utilizando testes estatísticos, que permitiram comparar as pontuações atribuídas por cada grupo a cada um dos RPs. Além disso, ilustra-se como foram avaliados os parâmetros e que tipo de correlação se estabeleceu entre eles. Por fim, passa-se à comparação das avaliações dos dois grupos, apresentada parâmetro por parâmetro, e à discussão, que incluiu as respostas abertas dos avaliadores, colocadas em diálogo com as respostas das entrevistas retrospectivas.

Nas considerações finais, além de retomar as perguntas de pesquisa que nortearam o trabalho, sintetizamos os principais resultados, expomos as limitações e dificuldades da pesquisa e indicamos também aplicações e perspectivas futuras. 


\section{1. “Luz, câmera, AÇÃO!": o role play sob múltiplas perspectivas}

Neste capítulo, são apresentados os pressupostos teóricos que guiaram a presente proposta de análise interdisciplinar do role play (RP). Em primeiro lugar, será explicado, a partir da perspectiva da Linguística, o processo de elaboração de um RP, desenvolvido para realizar pesquisas na área, e serão ilustradas as semelhanças e as diferenças entre os dados eliciados por meio da "encenação" e os dados ditos "naturalísticos", apontadas por estudos que investigaram especificamente essas questões $(\S 1.1)$.

Em segundo lugar, os aspectos que envolvem a encenação serão analisadas à luz do referencial teórico composto por teorias nascidas no âmbito das Artes Cênicas e pelos estudos desenvolvidos por Goffman (1975 [1959], 1981) sobre as interações cotidianas, considerando que, como já dissemos na introdução deste trabalho, a encenação é um dos principais elementos apontados como responsáveis por distanciar os dados eliciados por meio de RPs de uma língua que possa ser considerada representativa da fala "real" (§ 1.2).

Em seguida, práticas discursivas cotidianas, muitas vezes observadas apenas de um ponto de vista linguístico, serão revistas também da perspectiva da encenação. Serão analisados, em especial, os conceitos de competência comunicativa de Hymes (1972) e de cortesia (BROWN \& LEVINSON, 1987; CAFFI, 2009) (§ 1.3).

Por fim, será feita uma comparação entre os processos que envolvem o RP, assim como utilizado na Linguística, e as técnicas usadas por artistas em espetáculos teatrais e performativos. Com isso, procura-se compreender se e de que maneira o debate sobre a relação entre encenação e realidade, desenvolvido nas artes, pode oferecer uma contribuição para analisar os RPs, na medida em que alguns procedimentos por meio dos quais se busca uma aproximação à realidade - ou até a realidade em si - parecem estar presentes nas duas áreas de conhecimento $(\S 1.4)$.

\subsection{O role play como metodologia de coleta de dados: características e procedimentos}

Registrados em vídeo ou em gravações que contenham apenas os áudios dos diálogos, os RPs podem eliciar tipos diferentes de dados, à medida que coletam um maior ou menor número de componentes de uma interação. Ainda que a opção filmada pareça ser mais completa, pois mantém elementos como expressões faciais, informações sobre o "cenário" ou 
local de gravação, proximidade ou distância física entre os interlocutores, importantes sobretudo na hora da análise do material, a escolha de se produzir em vídeo ou em áudio está geralmente ligada à disponibilidade de tempo e de recursos que o pesquisador possui no momento da pesquisa. Além disso, essa decisão pode depender, também, do objeto a ser estudado. Vamos supor, por exemplo, que se queira refletir sobre o fenômeno da cortesia linguística, relacionando-o com observações sobre a entoação. Neste caso, um RP gravado apenas em áudio pode ser suficiente. Já para uma pesquisa que propõe a análise da cortesia de uma perspectiva multimodal, isto é, incluindo também o estudo de expressões faciais, gestos, disposição dos falantes no espaço etc. (KRESS, 2010), será necessário o uso da gravação também em vídeo, pois o material a ser observado vai além do que pode ser captado apenas pela linguagem.

Independente do modo como é registrado para posterior análise, existem na literatura, ao menos, três versões diferentes de RP: (a) fechado, (b) aberto (KASPER \& DAHL, 1991; FÉLIX-BRASDEFER, 2018) e (c) semiaberto (SANTORO, 2012; SANTORO \& NASCIMENTO SPADOTTO, 2019), que descreveremos a seguir. O uso de cada tipo implica processos diversos, além de influenciar a validade interna e externa da pesquisa, que, como já mencionamos na introdução, se refere ao maior ou menor grau de possível generalização dos resultados obtidos para toda a população.

É necessário pontuar que não existe uma metodologia ideal, mas metodologias mais ou menos adequadas ao escopo do pesquisador (PALLOTTI, 2001; JUCKER, 2018). Classificando as metodologias de coleta de dados mais utilizadas de acordo com o nível de validade interna e externa e de controle das produções dos informantes, Santoro (2012) elaborou o quadro que reproduzimos a seguir com algumas adaptações (Quadro 1): 
Quadro 1 - Classificação de metodologias de coleta de dados (validade interna e externa)

\begin{tabular}{|c|c|}
\hline \multicolumn{2}{|c|}{ Controle mínimo sobre as produções dos informantes - elevada validade externa. } \\
\hline Gravação secreta & $\begin{array}{c}\text { A interação não é guiada, os informantes não sabem que estão sendo } \\
\text { gravados. }\end{array}$ \\
\hline Gravação consentida & $\begin{array}{l}\text { A interação não é guiada, os informantes sabem que estão sendo } \\
\text { gravados. }\end{array}$ \\
\hline Gravação participante & A interação não é guiada, mas há a participação do pesquisador. \\
\hline Role play aberto & $\begin{array}{c}\text { A interação não guiada, os turnos de fala e sua duração não são pré- } \\
\text { determinados. }\end{array}$ \\
\hline Role play semiaberto & $\begin{array}{l}\text { A interação é parcialmente guiada, pois há um input que indica a } \\
\text { situação. Os turnos de fala e a sua duração não são pré-determinados. }\end{array}$ \\
\hline Role play fechado & $\begin{array}{l}\text { O roteiro da interação é pré-estabelecido e o número de falas é pré- } \\
\text { fixado (em geral, trata-se de apenas um turno). }\end{array}$ \\
\hline $\begin{array}{l}\text { Discourse Completion } \\
\text { Task oral }\end{array}$ & $\begin{array}{l}\text { A fala de um dos interlocutores é dada. } \\
\text { O informante completa oralmente. }\end{array}$ \\
\hline $\begin{array}{l}\text { Discourse Completion } \\
\text { Task escrito }\end{array}$ & $\begin{array}{l}\text { A fala de um dos interlocutores é dada. } \\
\text { O informante completa por escrito. }\end{array}$ \\
\hline Escolha Múltipla & $\begin{array}{l}\text { São apresentadas várias respostas possíveis para uma determinada } \\
\text { fala, o informante precisa apenas escolher entre elas. }\end{array}$ \\
\hline \multicolumn{2}{|c|}{ Controle máximo sobre as produções dos informantes - elevada validade interna. } \\
\hline
\end{tabular}

Fonte: adaptado de Santoro (2012, p. 105)

Observando, a partir do quadro apresentado, apenas a parte relativa aos tipos de RPs, vemos, em primeiro lugar, que eles se encontram em uma posição intermediária na escala das metodologias apresentadas. O RP fechado requer, porém, maior interferência do pesquisador no processo de coleta, resultando, portanto, em dados de mais elevada validade interna, enquanto o aberto é bastante frequente em pesquisas que se preocupam mais com a validade externa dos dados, ou seja, com sua maior correspondência com situações naturais. O terceiro tipo de RP é o chamado semiaberto, que Santoro em um de seus trabalhos descreveu assim:

(...) partia-se de scripts entregues por escrito apenas a quem iniciava a interação (papel A), aos quais o outro (papel B) devia reagir imediatamente, sem o tempo de preparar-se e sem que fosse dada nenhuma outra indicação sobre como gerenciar a interação que, com efeito, não previa que fossem pré-determinados nem o número de turnos de fala nem sua duração, como acontece, ao contrário, no role play dito "fechado". 
[(...) si partiva da script consegnati per iscritto solo a chi iniziava lo scambio (ruolo A), a cui l'altro (ruolo B) doveva reagire immediatamente, senza il tempo di prepararsi e senza che venisse data alcuna indicazione su come gestire l'interazione che infatti non prevedeva che venissero predeterminati il numero di turni e la loro durata, come avviene invece nel role play detto "chiuso".] (2013, p. 33)

Ainda observando o Quadro 1, podemos ver que esse tipo de RP se localiza exatamente no meio da classificação de metodologias apresentadas, o que indica que há nele alguns aspectos da validade interna e outros da validade externa. Como descrito, esse RP parte de um roteiro que define algumas características essenciais e prevê que um dos participantes receba a descrição de uma situação, com informações do cenário e da relação que ela tem com o interlocutor. Não se determina, contudo, como deve acontecer a troca de turnos, nem qual será a duração da interação, assim como ocorre em um RP aberto e também como ocorreria em uma situação de comunicação real.

$\mathrm{Na}$ tentativa de reduzir ao mínimo o efeito das interferências externas, a utilização do RP semiaberto no estudo citado foi ainda combinada com elementos que a pesquisadora chamou "corretivos" "(...) entre os quais não alterar a posição real e a relação efetiva existente entre os dois interlocutores" [(...) tra cui quello di non alterare la reale posizione e l'effettiva relazione esistente tra i due interlocutori] (SANTORO, 2013, p. 34). Para esse fim, "a instrução dada (...) era que 'continuassem sendo eles mesmos', e que tratassem o seu interlocutor (...) como fariam na vida real." [l'istruzione data (...) era che 'rimanessero se stessi' e che trattassero il loro interlocutore (...) come avrebbero fatto nella vita reale.] (p. 34), com o objetivo de propiciar a utilização de referências à experiência linguístico-comunicativa de cada participante.

Relembrando que todo processo de coleta de dados é um recorte da realidade promovido pelo pesquisador, e que, por isso, não há metodologia isenta de algum tipo de ação externa (LABOV, 1970; PALLOTTI, 2001), o uso de corretivos está diretamente ligado à tentativa de diminuir seus efeitos, o que evidencia a preocupação de manter a naturalidade dos participantes da gravação. Por outro lado, a definição de situações com características prédeterminadas, apresentadas a participantes diferentes exatamente da mesma forma, possui a indubitável vantagem de obter dados replicáveis e comparáveis, que permitem, além disso, manipular variáveis (EDMONDSON et al., 1984; KASPER, 2017) e, portanto, estudar a relação entre variáveis independentes, isto é, aquelas manipuladas pelos pesquisadores, e dependentes, com as quais se pressupõe que poderá ser observado o efeito do "experimento". 
Quando utilizado na área da Pragmática, o RP é geralmente criado de modo a eliciar um determinado ato de fala, como acontece, por exemplo, no caso dos pedidos. Para gravar em vídeo um RP semiaberto, tipologia que nos interessa de modo particular já que foi escolhida aqui como objeto de estudo, o pesquisador desenvolve um "roteiro", no qual não há falas prontas como em um texto dramático, mas as instruções das ações a serem realizadas pelos participantes da gravação (em geral, duplas). Em uma pesquisa que se propõe a analisar, por exemplo, como falantes de uma determinada língua fazem pedidos, esse roteiro é, muitas vezes, composto por indicações de uma determinada situação comunicativa, em que os indivíduos realizam pedidos, sem, porém, que esse ato de fala seja colocado de maneira explícita. É descrito o contexto que gera o pedido, o espaço em que acontece e são fornecidos detalhes para que os participantes possam "imaginar" a situação. Abaixo reproduzimos dois exemplos do trabalho realizado por Santoro (2013, p. 35), que descrevem duas das situações utilizadas também para esta dissertação, destacando que as descrições eram adaptadas à relação "real" entre os participantes e que, com base nisso, iniciavam de duas formas: ou apenas com a indicação do local (sei per strada [você está na rua]) ou com a especificação do local e a indicação de que a interação se daria entre amigos (sei per strada con un 'amica/un amico [você está na rua com uma amiga/um amigo]). Vejamos, então, o que era entregue a quem participava das gravações:

Você está na rua e quer anotar o número de telefone de um anúncio que viu. Percebe, porém, que não tem caneta.... o que você diz?

[Sei per strada e vuoi scrivere il numero di telefono di un annuncio che vedi passando. Ti accorgi, però, di non avere una penna con te... che cosa dici?]

Você está na rua e está atrasado. Precisa urgentemente telefonar para um amigo que fez uma longa viagem para te encontrar. $\mathrm{O}$ teu celular, por algum motivo inexplicável, não funciona e não têm telefones públicos por perto. Não há outra alternativa senão pedir um celular emprestado para uma ligação... o que você diz?

[Sei per strada e sei in ritardo. Devi urgentemente telefonare a un tuo amico che ha fatto un lungo viaggio per venire a trovarti. Il tuo cellulare per qualche inspiegabile motivo non funziona e non ci sono telefoni pubblici in giro. Non resta che cercare un cellulare in prestito per una telefonata... che cosa dici?]

Vê-se que ambas as descrições são compostas por indicações de uma situação comunicativa "cotidiana", do local físico em que ocorreria e, também, do motivo do pedido, alguns dos elementos essenciais que compõem eventos comunicativos (HYMES, 1974b). Ao 
final da instrução, pode-se perceber ainda que não é dada a indicação explícita de "pedir", substituída pela mais genérica pergunta “o que você diz?", que exclui voluntariamente o verbo pedir e, ao mesmo tempo, estimula o participante a imaginar sua fala na situação. A combinação dos componentes, à qual damos o nome de instrução, é descrita como setting ou cenário ${ }^{4}$ e, com algumas variações tanto na definição quanto na quantidade de informação, fornece elementos considerados fundamentais para eliciar as interações linguísticas (NICKELS, 2006).

Os participantes, aos quais esses elementos são fornecidos, poderão assim "improvisar" tanto a maneira como vão agir no contexto dado, quanto as palavras que vão dizer, partindo necessariamente de seu repertório e de suas experiências de vida e criando, embora "guiados" pelo pesquisador, situações que inevitavelmente se baseiam na realidade do falante e dão ao pesquisador o acesso "gravado" ao que pode acontecer na vida real.

\subsubsection{A Linguística e a busca por dados naturalísticos}

Com foco especial na naturalidade dos dados e tentando identificar os níveis de correspondência entre a língua eliciada e aquela produzida em conversações reais, foram desenvolvidos inúmeros estudos, nos quais, em geral, se contrapõem os diferentes tipos de amostra de língua existentes, como é o caso das comparações entre RP e de DCTs (RINTELL \& MITCHELL, 1989; EISENSTEIN \& BODMAN 1993; FÉLIX-BRASDEFER, 2003). Enquanto Rintell \& Mitchell (1989) dão ênfase às semelhanças entre as duas metodologias, os outros trabalhos mostram que o RP, de fato, apresenta dados mais completos que aqueles coletados por meio de questionários do tipo dos DCTs, pois os primeiros conservam elementos constitutivos da interação em língua falada (KASPER \& DAHL, 1991), que se perdem quando os dados são apenas escritos. Assim, para pesquisas que buscam observar o modo como falantes interagem a partir da língua, "dos métodos disponíveis para eliciar atos de fala na oralidade, alguns estudos apontam para o role play como uma medida mais válida de uso da língua autêntica, se comparado com questionários de produção escrita" ["Of the methods available to elicit spoken speech acts, some studies point to role plays as a more valid measure of authentic language use compared to written production questionnaires”] (BATALLER \& SHIVELY, 2011, p. 16).

\footnotetext{
${ }^{4}$ Enquanto o termo setting é descrito como "lugar contextualizado de uma situação com uma localização social" [contextualized place of a situation with a social location] o termo cenário ou "scenario" é usado para se referir a "eventos comunicativos contidos no setting" [speech events within a setting] (NICKELS, 2006, p. 256).
} 
Tentando atestar a autenticidade do que é produzido a partir de RPs, ainda outras comparações têm sido feitas entre eles e os chamados dados naturalísticos. Cabe, no entanto, uma observação: embora a necessidade de se estudar a língua a partir de material que corresponda ao máximo à realidade seja frequentemente explicitada (BAZZANELLA, 2008), a definição de "dados naturalísticos" não é muito precisa (PALLOTTI, 2001). Muitas vezes, o que uma vertente considera naturalístico, como, por exemplo, gravações secretas de interação face a face ${ }^{5}$, nas quais quem grava é o pesquisador, pode não ser um parâmetro indispensável de naturalidade para outros estudiosos, como acontece no caso do trabalho de Bataller \& Shively (2011), em que a gravação não é secreta, já que é realizada pelo próprio participante da pesquisa que grava sua própria fala em uma interação. Outro exemplo é a metodologia chamada de "anotações de campo" (field notes) que permite ao pesquisador uma recapitulação de uma interação observada, sem ter de pedir permissão para gravar uma interação (FÉLIXBRASDEFER, 2007). Com esse método, poderá ser utilizado apenas o que o pesquisador conseguiu observar e anotar, mas não será possível rever ou analisar os detalhes da interação, com a inegável perda de detalhes e uma interferência do pesquisador e de sua seleção ainda mais significativa. Outro problema enfrentado pelos estudiosos que escolhem utilizar dados naturalísticos em seus estudos é que

não há garantia de que o ato de fala sob investigação ocorrerá de uma determinada forma ou que serão produzidos e coletados em número suficiente, já que o pesquisador não tem muito controle sobre a produção dos informantes.

[there is no guarantee that the speech act under investigation will occur at all or enough tokens will be produced and collected since the researcher does not have much control over informants' production.] (YUAN, 1999, p. 275)

Sem essas garantias e com o agravante de que, em alguns países, é ilegal filmar ou gravar áudios de pessoas sem avisá-las, as pesquisas científicas que geralmente têm tempo de duração limitado acabam optando por instrumentos como o RP, pois apresentam maior segurança para o desenvolvimento dos trabalhos, respeitando também as questões éticas.

Vamos agora nos concentrar especificamente nas pesquisas que comparam RPs e dados considerados naturalísticos e que, de fato, indicam a presença de diferenças entre eles. Entre os principais estudiosos que se dedicaram a analisar essa questão, podemos mencionar FélixBrasdefer (2007), Eisenstein \& Bodman (1993), Bataller \& Shively (2011). Dois dos aspectos

\footnotetext{
${ }^{5}$ Por "gravações secretas de interação face a face" entende-se, essencialmente, a gravação secreta de conversas espontâneas, como descrito no Quadro 1, p. 20.
} 
mais frequentemente observados nas pesquisas são: (1) a presença de sentenças mais longas em ocorrências naturais (FÉLIX-BRASDEFER, 2007); (2) a existência de pequenos diálogos não diretamente relacionados ao tema do pedido, que aparecem apenas em dados naturalísticos, conforme descrito, por exemplo, nos resultados de uma pesquisa sobre esse ato de fala, realizada com aprendizes estadunidenses de espanhol (BATALLER \& SHIVELY, 2011).

As dissimilaridades entre a língua produzida em contextos "reais" e em RPs não surpreendem, já que as circunstâncias de produção são distintas. Merece destaque, contudo, que as mesmas pesquisas indicam também similaridades e evidenciam nos RPs informações pragmalinguisticas parecidas às encontradas nos dados naturalísticos (FÉLIX-BRASDEFER, 2007, p. 171). É o que podemos ver na pesquisa sobre pedidos de Bataller \& Shively (2011), previamente citada, na qual se constata, por exemplo, a mesma recorrência de pedidos que acontecem, inclusive, com uma frequência análoga. Com efeito, segundo as pesquisadoras, os aprendizes utilizaram a fórmula "puedo tener" do espanhol praticamente o mesmo número de vezes nas gravações realizadas utilizando as duas metodologias (35\% nos RPs e $33 \%$ nas gravações “espontâneas"). Mais uma característica dos dois tipos de dados que revela analogias é a ocorrência do mesmo número de estratégias: "um total de sete diferentes estratégias foram encontradas em ambos os conjuntos de dados" ["a total of seven different strategies were found in both data sets"], reportam as autoras (BATALLER \& SHIVELY, 2011, p. 29). Esses e outros resultados nos indicam que, de fato, "as interações dos role plays capturam muitas das características do discurso autêntico" [role-play interactions captured many of the features of authentic discourse] (BATALLER \& SHIVELY, 2011, p. 45), o que poderia ser um indício de que falantes que participam de RPs, empregam nessas produções seus próprios comportamentos linguísticos "autênticos" ou "reais".

Como já foi sinalizado na introdução do presente trabalho, apesar dos aspectos positivos, a utilização de RPs em pesquisas que buscam compreender as formas de uso reais de determinada língua, levanta, entre os especialistas, questionamentos sobre a autenticidade dos dados, sobretudo no que diz respeito à questão da encenação, que é o procedimento por meio do qual essas produções linguísticas são eliciadas. Com efeito, ao longo dos anos, os linguistas têm interpretado os RPs, contrapondo a representação de papéis, própria da encenação, à realidade, e adotando a definição segundo a qual "um role play é sempre uma simulação (...), na qual os participantes 'assumem' e 'atuam' em 'papéis' especificados, muitas vezes, dentro de uma estrutura social pré-definida ou plano situacional (um 'cenário')" [a role-play is always 
a simulation (...) in which participants 'take on' and 'act out' specified 'roles', often within a predefined social framework or situational blueprint (a 'scenario')] (CROOKALL \& SAUNDERS, 1989, p.16). Embora tais afirmações por si só não explicitem uma relação de oposição entre esses dois elementos, elas são geralmente usadas com esse fim, sempre que a linha seguida pelo pesquisador for a de defender os dados naturalísticos como único modo confiável de captar e analisar o uso real de uma língua. Ao compararem o participante do RP com um ator, na medida em que retratam como encenação tanto suas ações físicas quanto o modo como fala, uma parte da comunidade científica trata a língua produzida em RPs como distante da realidade porque imaginada (WILDNER-BASSETT, 1989; GOLATO, 2003). Por isso, segundo Félix-Brasdefer, mesmo sendo capaz de fornecer amostras de língua muito similares a ocorrências naturais, "uma das principais críticas contra o método role-play é que ele reúne dados artificiais ou simulados, já que os participantes são solicitados a imaginar uma situação que pode ou não ter acontecido com eles na vida real" [One of the main criticisms against the role-play method is that it gathers artificial or simulated data, as participants are asked to imagine a situation that may or may not have happened to them in real life] (FÉLIXBRASDEFER, 2018, p.324).

Nessa concepção, o RP seria, portanto, sempre uma simulação, uma representação de como o indivíduo acredita que agiria em determinada situação. No entanto, Crookall, Oxford \& Saunders (1987), estudando especificamente essa questão, apontaram que as pesquisas baseadas em simulação podem, na verdade, assumir duas perspectivas de análise diferentes. A primeira, de certa forma já explicada, é a que chamam perspectiva representacional e identifica as ações simuladas como “ 'meras' representações de algum outro sistema pertencente ao 'mundo real' "[" 'merely' representations of some other 'real worldly' system] (CROOKALL et al., 1987, p.149). Como vimos, esse parece ser o caminho geralmente escolhido por quem descreve os dados de RPs, julgando-os inverossímeis e justificando essa posição com a afirmação de que "como representação, a simulação não é o mundo 'real' ou 'de fora' " ["as a representation, simulation is not the 'real' or 'outside' world"] (1987, p. 153). Além dessa, há, porém, uma segunda perspectiva de análise, que denominam "realística", que, ao contrário, vê simulações como realidades específicas ou “ 'realidades operacionais' por direito próprio, ou seja, como não tendo necessariamente poder ou valor representativo, direto ou explícito. Pode ser denominada 'simulação-como-realidade- em-seu-próprio-direito' ou a perspectiva da 'realidade' " [“(...) 'operating realities' in their own right, i.e. as not necessarily having direct or explicit representational power or value. This may be termed the 'simulation-as-reality-inits- own-right' or the 'reality' perspective”] (CROOKALL et al., 1987, p. 149). Os autores 
partem, então, da realização da ação e enxergam a simulação, da qual o RP é parte ${ }^{6}$, não como a representação de uma outra realidade, mas, sim, como a realidade específica do instante em que está ocorrendo. Deste modo, durante o processo de elaboração do RP, o participante estaria sempre simulando determinado comportamento, ao mesmo tempo em que estaria também vivenciando a situação proposta pelo pesquisador, mas

A simulação (...) traz um simulador "para a vida", e isso só pode ser alcançado pelos participantes. Ao ser ativado, ele assume uma realidade própria e deixa o domínio da representatividade "pura". Durante uma simulação, a noção ou sensação de representatividade é perdida ou destilada, à medida que a simulação começa a ganhar vida própria.

[Simulation (...) brings a simulator "to life", and this can only be achieved by participants. In being activated, it takes on a reality of its own, and leaves the domain of "pure" representativity. During a simulation the notion or feeling of representativity is lost or distilled, as the simulation begins to take on a life of its own.] (CROOKALL et al., 1987, p.154)

Em outras palavras, o instante em que o participante está simulando um comportamento é percebido por ele como realidade, pois, enquanto simula, esse indivíduo está também vivenciando a situação. Deste modo, "uma simulação pode se tornar uma situação totalmente real para os participantes" ["a simulation can become a totally real situation for participants"] (CROOKALL et al., 1987, p. 153), aspecto interessante de se considerar, sobretudo quando uma pesquisa busca partir da perspectiva Pragmática, que propõe uma análise da interação entre falantes, considerando o próprio falante no contexto dessa interação (CRYSTAL, 1997). Ao focalizar a realização da simulação, a chamada perspectiva realística permite que se parta intrinsecamente do ponto de vista do falante, aquele que participa do RP, podendo ser este um caminho profícuo para estudos que se propõem a analisar a língua com dados "reais", mas, paralelamente, controláveis e com variáveis manipuláveis para fins de pesquisa.

Em seu texto, Crookall et al. (1987) não sugerem a utilização concomitante das duas perspectivas que propõem, mas ressaltam a necessidade de considerar de modo mais aprofundado o ponto de vista que chamam "realista", algo que nos daria, justamente, a possibilidade de ampliar a maneira como os RPs são analisados.

\footnotetext{
${ }^{6}$ No texto de 1987, os autores explicam que a simulação é uma categoria mais ampla que o RP, em suas palavras "Role plays é visto simplesmente como um aspecto da simulação; a simulação pode nem sempre incorporar o role play, mas um role play é sempre uma simulação. ["Role play is seen as simply one aspect of simulation; simulation may not always incorporate role play, but a role play is always a simulation.”'] (CROOKALL et al. 1987, p. 147)
} 


\subsection{Conexões entre realidade e encenação: interações reais e simuladas}

Se linguistas pontuam que nos RPs elaborados para coletar dados os participantes estão representando papéis como se fossem atores, é preciso observar que mesmo a vida real pode ser vista como encenação. Aliás, o que artistas e teóricos de diferentes áreas defendem é que a encenação é, antes de tudo, parte da realidade cotidiana (GOFFMAN, 1975 [1959]), além de poder ser, também, um recurso para “captar” essa realidade.

Para pensar no RP considerando essas vertentes, pode ser um bom ponto de partida lembrar que, muito antes da afirmação de Pirandello que citamos na introdução deste trabalho, William Shakespeare, um dos dramaturgos mais conhecidos da história do teatro mundial, já ilustrava a ideia de vida real como encenação. Entre 1599 e 1600, Shakespeare escreve a comédia "As You Like it", na qual diz "O mundo é um palco e todos os homens e mulheres são na verdade atores: têm suas saídas e suas entradas e no decorrer da vida atuam em vários papéis (...)" ["All the world's a stage, And all the man and women, meerely Players; They have their Exits and their Entrances, And one man in his time playes many parts (...)'] (SHAKESPEARE, 2011 [1623], p. 54). Embora o teatro tradicional não seja o nosso objeto de estudo, a consideração de Shakespeare é importante, pois ilustra a relação entre encenação e vida real, mesmo dentro do âmbito da arte de encenar. Além disso, tanto em Shakespeare quanto em Pirandello, os seres humanos parecem ser retratados como atores capazes de encenar não um, mas uma multiplicidade de papéis, tão variada quanto as situações da própria vida.

Lembrando que em RPs de pesquisa quem "encena" é justamente esse ser humano comum $^{7}$, antes de analisarmos a naturalidade de encenações elaboradas por falantes nativos de italiano, proposta central da presente pesquisa, é necessário partir do pressuposto de que qualquer pessoa é capaz de encenar. Tal ideia é ilustrada não apenas nas artes, mas parece estar implícita, inclusive, na própria crítica à metodologia, que, como vimos, compara o RP com representações realizadas por atores.

Entre aqueles que investigaram a capacidade humana de encenar, está o diretor teatral e dramaturgo brasileiro Augusto Boal, cuja obra tem como um de seus principais objetivos ${ }^{8}$

\footnotetext{
${ }^{7}$ Pode participar de um RP qualquer pessoa que aceite fazer parte da pesquisa, dependendo das especificidades do estudo e do escopo do pesquisador. Em pesquisas que estudam, por exemplo, competência pragmática em aprendizes de L2, são os estudantes dessa segunda língua a atuar; em pesquisas que se propõem estudar o comportamento linguístico cross-cultural, quem encena são os falantes nativos das diferentes línguas observadas. ${ }^{8}$ Boal acreditava que a sociedade pudesse ser transformada pelo teatro, mas um teatro realizado pelo cidadão comum que, colocando em cena suas próprias questões e debatendo os problemas sociais que o circunda,
} 
colocar o cidadão comum "não ator" para atuar no lugar do ator profissional. Embora o foco do diretor estivesse no emprego e na análise desse tipo de encenação em âmbito teatral, é preciso pontuar que, em sua visão, a encenação é mais do que uma escolha em um momento específico (um espetáculo teatral), sendo, na verdade, uma capacidade inata. Em suas palavras:

Todo mundo atua, age, interpreta. Somos todos atores. Até mesmo os atores! Teatro é algo que existe dentro de cada ser humano (...) A linguagem teatral é a linguagem humana por excelência, e a mais essencial. Sobre o palco, atores fazem exatamente aquilo que fazemos na vida cotidiana, a toda hora e em todo lugar. Os atores falam, andam, exprimem ideias e revelam paixões, exatamente como todos nós em nossas vidas no corriqueiro dia a dia. A única diferença entre nós e eles consiste em que os atores são conscientes de estarem usando essa linguagem, tornando-se, com isso, mais aptos a utilizá-la. Os não atores, ao contrário, ignoram estar fazendo teatro, falando teatro, isto é, usando a linguagem teatral (BOAL, 2015, p. 13)

Como se vê, o diretor explica que todos os indivíduos são dotados da mesma aptidão para encenação, sejam eles atores ou não. Aliás, é justamente por isso que Boal afirma que "até mesmo os atores são atores" e, sem categorizar as encenações como "boas" ou "ruins", evidencia a consciência de estar encenando como o principal traço que distinguiria o ator profissional do "não ator”. Abordaremos a questão da consciência da encenação mais adiante, neste momento, o que importa é perceber que, para Boal, a representação teatral só existe, pois os atores (profissionais) atuam levando ao palco exatamente as mesmas ações e as mesmas palavras, por meio das quais atuam e falam também na vida real. Trata-se de um detalhe particularmente significativo para a nossa argumentação, pois, se também a fala de atores e "não atores" é encenada tanto no palco quanto na vida real, a língua eliciada por meio de RPs - que são encenação - seria tão autêntica quanto aquela utilizada na vida real.

A afirmação de que todos os seres humanos são capazes de encenar caracteriza também o trabalho "The presentation of Self in everyday life" [“A representação do Eu na vida cotidiana"], tese doutoral de Goffman, publicada, pela primeira vez, em 1956 e, em versão revista, em 1959. No livro, o autor analisa a questão da representação sob outro prisma, defendendo que as interações da vida real podem ser estudadas na perspectiva do teatro, pois a própria vida estaria organizada como uma peça teatral (p. 71), já que os indivíduos vivem e interagem uns com os outros, justamente por meio da representação. Para introduzir esse pensamento, Goffman usa a seguinte citação de Park: 
Não é provavelmente um mero acidente histórico que a palavra "pessoa", em sua acepção primeira, queira dizer máscara. Mas, antes, o reconhecimento do fato de que todo homem está sempre e em todo lugar, mais ou menos consciente, representando um papel... É nesses papéis que nos conhecemos uns aos outros; é nesses papéis que nos conhecemos a nós mesmos. (1950, p. 249 apud GOFFMAN, 1975 [1959], p. 27)

Aqui cabe observar que as afirmações de Park $^{9}$, retomadas por Goffman, entendem a competência de representar não só como uma habilidade do ser humano, mas como um elemento que constitui sua essência, já que é exatamente a partir dessa prática que ele se reconhece. De acordo com tal perspectiva, as encenações ou "máscaras" seriam uma parte fundamental da realidade, ideia que vai na contramão da dicotomia "representação" vs. "vida real", na qual parece se basear a crítica ao RP. Ora, se a própria vida é constantemente representação de papéis, não estaria quem participa de um RP apenas fazendo o que pertence ao seu cotidiano?

Como já pontuamos, para Boal (2015), a diferença entre ator e "não ator" não está na capacidade de encenar, mas na consciência de estar encenando. A esse respeito, Goffman acrescenta que, embora os atores profissionais sejam mais "hábeis" em estender à cena teatral a capacidade cotidiana de criar alusões e simulações “(...) transferindo a habilidade de reevocar além daquela possuída pelo resto de nós” [“(...) carrying the ability to reinvoke beyond that possessed by the rest of us"] (1981, p.2), existem contextos cotidianos em que também o "não ator" atua de modo consciente. Uma vez que, mesmo na vida, a intenção do indivíduo é a de manter a imagem que criou de si, a fim de não ser descredibilizado diante de seu interlocutor (cf. GOFFMAN, 1967), às vezes os seres humanos agirão "de maneira completamente calculada, expressando-se de determinada forma somente para dar aos outros o tipo de impressão que irá provavelmente levá-los a uma resposta específica que lhe interessa obter." (GOFFMAN, 1975 [1959], p. 15). Essa atuação consciente, que possui o objetivo de favorecer a própria imagem, é evidente, por exemplo, na forma como as pessoas se apresentam em entrevistas de emprego ou em eventos acadêmicos. Em interações desse tipo, uma representação "mal feita" pode influenciar de forma negativa a realidade do indivíduo por um período de tempo maior do que o simples momento da representação, o que justifica seu

\footnotetext{
${ }^{9}$ Robert Ezra Park é um jornalista e sociólogo americano (1864 - 1944), que estudou dentre outras coisas, a influência do ambiente no sujeito. É um dos fundadores da Escola Sociológica de Chicago ou "Escola de Chicago", importante movimento nascido em 1910, com a participação dos docentes das áreas de Sociologia da Universidade de Chicago, que investigava o surgimento e o desenvolvimento de fenômenos sociais em grandes centros urbanos americanos.
} 
interesse de construir para si e para o outro a "máscara" mais adequada, fazendo o interlocutor crer que ele é o que está dizendo ser. Goffman afirma, ainda, que

outras vezes, o indivíduo estará agindo calculadamente, mas terá, em termos relativos, pouca consciência de estar procedendo assim. Ocasionalmente, expressar-se-á intencional e conscientemente de determinada forma, mas, principalmente, porque a tradição de seu grupo ou posição social requer este tipo de expressão (GOFFMAN, 1975 [1959], p. 15)

Em outras palavras, essas considerações mostram que a consciência de "estar encenando" está presente em graus diferentes em todos os seres humanos. Acontece, contudo, que, em determinados momentos, a encenação real parece não ser guiada pelas intenções ou pela tentativa de realizar ações que favoreçam o indivíduo, mas pelo contexto social no qual ele se encontra, que determina a forma como vai agir. Deste modo, faria parte de encenações mais induzidas pelo contexto, por exemplo, a alternância de comportamento que ocorre cotidianamente na vida de juízes e advogados, que são obrigados a agir de maneira extremamente formal dentro de um ambiente de trabalho específico que requer tal conduta, mas que abandonam tal formalidade ao final do expediente ou sempre que deixam esse local. Partindo dessas considerações, na seção a seguir, trataremos, em especial, da relação que se estabelece entre os inputs $^{10}$ externos ao indivíduo e a maneira como são construídas as máscaras encenadas na vida cotidiana.

\subsubsection{As representações de si e a construção de máscaras cotidianas}

Como vimos na seção anterior, Goffman (1975 [1959]) ilustra as interações cotidianas usando a perspectiva do teatro e, com isso, indica que é por meio da representação de papéis que os indivíduos interagem nas mais variadas situações da vida. Na visão do autor, a representação ${ }^{11}$ é "toda a atividade de um indivíduo que se passa num período caracterizado por sua presença contínua diante de um grupo (...) de observadores e que tem sobre estes alguma influência" (p. 29). Fica evidente a partir dessa definição que qualquer interação humana poderia ser caracterizada como representação, e que isso não se limita ao teatro ou a ações simuladas como as que se realizam por meio de RPs.

Para entender o paralelo entre vida e teatro elaborado pelo autor, é preciso, antes, esclarecer conceitos centrais na obra de Goffman (1975 [1959]) como os de "papel social" e

\footnotetext{
10 Para o presente trabalho, input é qualquer informação ou estímulo disponível para o indivíduo no contexto.

${ }^{11}$ Embora, no presente trabalho utiliza-se o termo "representação" indicado pela tradução, ou ainda "encenação", o termo utilizado pelo autor na versão original, em inglês, é "performance".
} 
"fachada", essenciais também para definir o modo como são criadas pelos seres humanos as "máscaras" representadas na vida. Nessa concepção, os papéis sociais são movimentos ligados a uma determinada situação e que podem ser representados pelos "atores" (termo usado por Goffman para indicar os indivíduos comuns) "para o mesmo tipo de público ou para um público formado pelas mesmas pessoas" (p. 24). À vista disso, podemos entender os papéis sociais também como "máscaras" de si mesmo, que o indivíduo elabora para atuar em contextos determinados, e que se repetem sempre que se repetir a situação e/ou o interlocutor. Já a "fachada" (em inglês, "front") é o conjunto de elementos usados pelo ator para constituir esses papéis ou, nas palavras de Goffman, "o equipamento expressivo de tipo padronizado intencional ou inconsciente empregado pelo indivíduo durante sua representação" (p. 29). Com a função de "definir a situação para os que observam a representação" (p. 29), esses elementos podem ser divididos em dois grupos: aqueles relacionados ao "cenário" ou ao ambiente em que as representações ocorrem; e aqueles que compõem a chamada "fachada pessoal" (p. 31). Enquanto o cenário, embora disponível, muitas vezes não depende diretamente do "ator", a fachada pessoal é composta por "distintivos da função ou categorias, vestuário, sexo, idade e características raciais, altura e aparência, atitude, padrões de linguagem, expressões faciais, gestos corporais e coisas semelhantes" (GOFFMAN, 1975 [1959], p. 31), ou seja, são as características físicas e comportamentais do próprio ator.

Além de dividir o conceito de fachada entre "cenário" e "fachada pessoal", em um segundo momento, Goffman (1975 [1959]) específica que a fachada pessoal é composta por dois tipos de características, aquelas ligadas à "aparência", isto é, "estímulos que funcionam no momento para nos revelar o status social do ator" (p. 31) (por exemplo, quem ele é, que tipo de trabalho faz, qual atividade vai realizar na interação) e aquelas ligadas à "maneira" ou ao modo como o indivíduo vai encenar (por exemplo, mais humilde ou mais imperativo).

A partir desses conceitos, podemos dizer que, embora as máscaras cotidianas sejam inicialmente uma criação do próprio ator, o processo que leva à sua criação não ocorre de maneira totalmente autônoma, mas depende de um ambiente ou cenário específico, da definição de uma situação e também da interação com um ou mais interlocutores, o que nos faz pensar que elementos como ambiente, situação e interlocutor devam ser considerados constitutivos de qualquer contexto de interação.

Ainda observando a construção dos papéis proposta por Goffman (1975 [1959]), veremos que, uma vez que uma única interação não nos permite conhecer a totalidade da 
natureza da pessoa que está diante de nós, mas apenas a "máscara" que essa pessoa deseja mostrar - as interações cotidianas, ou as nossas representações nessas interações são, geralmente, construídas a partir de inferências e pressuposições:

Se o indivíduo lhes for desconhecido, os observadores podem obter, a partir de sua conduta e aparência, indicações que lhes permitam utilizar a experiência anterior que tenham tido com indivíduos aproximadamente parecidos com este que está diante deles ou, o que é mais importante, aplicar-lhes estereótipos não comprovados. Podem também supor, baseados na experiência passada, que somente indivíduos de determinado tipo são provavelmente encontrados em um dado cenário social. (GOFFMAN, 1975 [1959], p. 11)

Desse modo, cada vez que os sujeitos interagem na vida real, lembrando que sempre farão isso construindo representações de si uns para os outros, essa ação estará vinculada não apenas à situação e ao espaço em que ocorre, mas dependerá também das experiências vividas anteriormente por cada um dos participantes da interação. Aqui podemos observar que o indivíduo pressupõe e define como deve agir, justamente, a partir dos três elementos previamente citados: a situação, o cenário ou ambiente e também da imagem que cada participante da interação constrói do outro e de si mesmo por meio de elementos presentes na fachada pessoal. É necessário lembrar que esse percurso de pressuposição e elaboração do papel é concomitante àquele realizado pelo interlocutor, pois, na vida, ora somos atores, ora somos interlocutores e/ou plateia, ou ainda, como ilustrado por Boal na epígrafe do presente trabalho, "somos espect-atores" (2015, p. 13).

Diferenciando as representações cotidianas reais e as que ocorrem no teatro, Goffman afirma que "na vida real os três elementos (ator, interlocutor e plateia) ficam reduzidos a dois: o papel que um indivíduo desempenha é talhado de acordo com os papéis desempenhados pelos outros presentes e, ainda, esses outros também constituem a plateia.” (1975 [1959], p. 9). Ainda no texto de 1975 [1959], Goffman não parece diferenciar os processos de inferência e de pressuposição de maneira explícita, mas indica que, em uma interação, o nosso interlocutor age segundo dois tipos diferentes de informações que compartilhamos com ele: as "transmitidas" e as "emitidas". O autor explica que "a primeira abrange os símbolos verbais, ou seus substitutos, que ele usa propositadamente e tão só para veicular a informação (...). A segunda inclui uma ampla gama de ações, que os outros podem considerar sintomáticas do ator" (GOFFMAN, 1975 [1959], p. 12). Se observarmos tais elementos do ponto de vista linguístico, perceberemos que a pressuposição poderia ser considerada equivalente às "informações transmitidas", pois se trata de um "conteúdo que está conectado com um enunciado não porque esse enunciado o afirma, mas porque a produção do enunciado informa que o emissor considera esse conteúdo 
óbvio" ["contenuto che sia connesso con un enunciato linguistico non perché l'enunciato lo asserisca, ma perché la produzione dell'enunciato informa che l'emittente dà per scontato tale contenuto”] (VALLAURI, 2009, p. 13). Já as inferências são “informações provenientes da interpretação da situação comunicativa (...)" ["informazioni che provengono dall 'interpretazione della situazione comunicativa (...)'] (ANDORNO, 2005, p. 91) e, por isso, poderíamos relacioná-las ao que Goffman aponta como a informação que o indivíduo emite e que é interpretada pelo outro. Com isso, podemos dizer que as máscaras ou representações da vida cotidiana são baseadas tanto nas informações explícitas presentes no cenário, na fachada pessoal do interlocutor e no que é dito pelo interlocutor no momento da interação, quanto naquelas "informações" que o próprio indivíduo infere, ou seja, do que ele acredita tratar a situação e de quem ele acredita ser seu interlocutor, baseando-se no seu conhecimento prévio construído em situações semelhantes.

Próximo do que acontece nas interações cotidianas, também durante um RP, o participante procura encenar, simulando o comportamento que pressupõe adequado à situação proposta pelo pesquisador, baseando-se nas informações "transmitidas" por esse contexto e também em suas experiências já vividas anteriormente. Como explicam Crookall, Oxford \& Saunders, "a maioria do que ocorre durante uma simulação é possível porque os participantes trazem consigo para a performance seu conhecimento do mundo e de como ele funciona" ["most of what goes on during a simulation is made possible because participants bring with them to the performance their knowledge of the world and how it works"] (1987, p. 164). Deste modo, a representação estaria entre o que ocorre em uma cena teatral e o que se dá na realidade, uma vez que uma "encenação (...) implica no uso de técnicas verdadeiras, as mesmas técnicas graças às quais as pessoas na vida diária mantêm suas situações sociais reais" (GOFFMAN, 1975 [1959], p. 233). Assim, a pressuposição, por meio da qual se concretiza o acesso ao passado das experiências vividas, pode permitir o acesso à parte "real" da representação de um RP. Pensando que, inclusive, do ponto de vista linguístico o RP resulta de um acesso do mesmo tipo ao passado e, portanto, à realidade, poderíamos, então, considerá-lo como representante fidedigno do modo como as pessoas se comunicam na vida, já que toda e qualquer ação linguística, seja na representação de um RP seja na vida, também seria calcada nesse conhecimento do real reativado pela pressuposição.

Se retornarmos, porém, aos questionamentos levantados por linguistas sobre a naturalidade de dados coletados por meio de RPs, veremos que o maior problema envolvido na 
questão da encenação parece ser que, em alguns processos, os participantes não viveram previamente essas experiências e, portanto, devem representar a partir da imaginação, tanto da situação quanto do "papel" proposto pelo pesquisador. Por isso, linguistas como Golato afirmam que no tipo de RP em que se pede para o participante, por exemplo, fazer um elogio, atuando em um papel que não necessariamente faz parte de sua realidade, seria

mais adequado dizer que tais participantes estão encenando como imaginam que alguém nessas situações possa elogiar. Em outras palavras, não apenas os sujeitos estão novamente fornecendo suas crenças sobre a interação, mas aqui eles podem estar fornecendo crenças sobre papéis que nunca desempenharam na vida real.

[(...) more accurate to say that such participants are acting out how they imagine someone in these situations might give compliments. In other words, not only are subjects again providing their belief about interaction, here they may be providing beliefs about roles they have never played in real life.] (GOLATO, 2003, p. 94)

Explicadas desse modo no campo da Linguística, as ações baseadas na imaginação seriam exatamente o que confere certo distanciamento entre os dois tipos de língua, a "real" e a "encenada", na medida em que a imaginação é vista como um elemento destacado da realidade. Contudo, voltando nosso olhar novamente às Artes Cênicas, veremos que a imaginação, empregada na construção de uma representação, é identificada como um elemento calcado justamente no real, porque "a matéria prima da imaginação é sempre tirada da vida" (TCHEKHOV, M. apud BERTHOLD et al., 2001, p. 463) e, por isso, não haveria a possibilidade de imaginar, seja uma situação, seja um papel, sem que se parta da própria realidade.

Para tratar especificamente da imaginação empregada nas representações de RPs à luz da perspectiva artística, podemos observar as considerações do diretor e dramaturgo russo Constantin Stanislavski, sobre o que ele chama de "memória afetiva" e que, em alguns aspectos, parece funcionar de modo semelhante ao processo de pressuposição descrito na obra de Goffman (1975 [1959]). Baseado nas ideias do psicólogo francês Théodule-Armand Ribot, o diretor desenvolveu o conceito "memória afetiva" (CAVAGNA \& RUSH, 2019), renomeandoo posteriormente como "memória emocional" (VÁSSINA \& LABAKI, 2015, p. 309) o qual pode ser descrito como um repertório de ações observadas ou vividas previamente (na vida real) e que deveria ser acessado de modo consciente pelos atores no momento da encenação. Sobre essa memória, Vássina \& Labaki (2015) reportam em seu livro dedicado a Stanislavski as afirmações do próprio dramaturgo que explica: 
(...) sua memória visual faz com que você consiga reviver diante de seu olhar interior um objeto esquecido há muito, uma paisagem ou uma pessoa. (...) $\mathrm{O}$ processo de cristalização das lembranças e das sensações se realiza na memória emocional. Todo homem já viu em sua vida um enorme número de catástrofes. Retemos suas memórias, não em todos os seus detalhes, mas apenas os traços que mais nos impressionaram. De várias lembranças daquilo que foi vivido se forma uma recordação vasta, condensada, ampliada, mais profunda sobre os sentimentos parecidos. Nessa memória não há nada de supérfluo; só fica o essencial. É a síntese dos sentimentos homogêneos... É a memória em grande escala. Ela até é mais pura, mais compacta, mais rica de conteúdos e mais penetrante de que a própria realidade. (p. 309)

A memória afetiva ou emocional seria, portanto, construída a partir de recortes selecionados da realidade que, ao serem ativados, poderiam trazer de volta detalhes de situações e até as sensações de um momento anteriormente experienciado. Se, como dito, na memória se mantém só o essencial, e se esse essencial é, antes de tudo, uma espécie de seleção pessoal de vivências passadas, quando ela for aplicada em determinada encenação, seria capaz de conferir à cena, muito mais do que um caráter verossímil, implementando, inclusive, traços específicos e personalizados das experiências vividas em situações reais por quem está representando.

O trabalho do ator ocupa lugar central na obra de Stanislavski que, em seus estudos empíricos, unia diversas áreas da ciência à arte, a fim de compreender melhor tanto a natureza da representação quanto os modos como ela poderia ser elaborada e reproduzida por um ator criador, de maneira orgânica, verdadeira e não mecanizada. Para o diretor, o trabalho do ator consistia em "dotar cada ato do comediante em cena de uma motivação genuína e real, profundamente personalizada, psicologicamente articulada no contexto do próprio sujeitoator"' (GUINSBURG, 1985, p. 42). Por isso, na concepção de representação de Stanislavski, a realidade parece ser o elemento basilar, do qual depende toda encenação, e no qual estariam calcadas tanto a imaginação, que o ator emprega na construção de papéis quanto a própria representação, ou seja, a ação realizada de modo consciente pelo ator. Assim, o conjunto de seus estudos nomeados posteriormente "O Método Stanislavski” é composto também - ou sobretudo - pela descrição e pelos relatos de técnicas, criadas para guiar o ator na construção, a partir de sua própria vida real, de um personagem que poderia ser tanto próximo quanto distante dessa realidade do ator. Observando esse aspecto Simonov ${ }^{12}$ (2018 [1962]) explica:

12 Ao texto "Metod K.S. Stanislavskogo i fisiologija emocij" (1962), de Pavel Vasil'evich Simonov, do qual é extraída a citação, tivemos acesso pela tradução em italiano, intitulada "Il metodo Stanislavski e la fisiologia delle emozioni”, disponível em: https://www.teatrodinessuno.it/doc/stanislavskij/fisiologia-emozioni (último acesso em: 06/03/2021). 
Prescindir da realidade ("se eu estivesse no lugar de Hamlet ...") combina-se dialeticamente com a tendência oposta de estar o mais próximo possível da realidade. O artista não se questiona: "Como Hamlet se comportaria nas circunstâncias dadas?", ele sempre se pergunta: "Como eu me comportaria se estivesse no lugar de Hamlet?". Não é difícil ver que no primeiro caso ("como Hamlet deve se comportar") é necessário um grau mais alto de abstração do que no segundo. Ao implementar suas próprias ações no lugar do personagem interpretado, o artista usa sua própria experiência natural vivida para representar essas ações, esses atos que ele se viu realizando em condições semelhantes às circunstâncias dadas.

[Il prescindere dalla realtà ("se fossi al posto di Amleto...") si combina in modo dialettico con la tendenza opposta di essere quanto più possibile vicino alla realtà. L'artista non si pone la domanda: "Come deve comportarsi Amleto nelle circostanze date?", egli si chiede sempre: "Come mi comporterei se fossi al posto di Amleto?". Non è difficile vedere che nel primo caso ("come deve comportarsi Amleto") occorre un grado di astrazione più alto che nel secondo. Attuando le proprie azioni al posto del personaggio interpretato, l'artista utilizza la propria naturale esperienza vissuta, per rappresentare quelle azioni, quegli atti che si è trovato a svolgere in condizioni simili alle circostanze date.] (SIMONOV, 2018 [1962], np, grifo do autor)

É interessante perceber que é a partir dessa "realidade personalizada", ou seja, dos contextos cotidianos de quem representa e também de "circunstâncias dadas" (como as indicações presentes em um texto dramático) que o ator de Stanislavski se vê capaz de encenar de modo natural, inclusive, personagens clássicos. Embora os estudos sobre a memória afetiva, desenvolvidos pelo dramaturgo, visem ao uso da memória por parte do ator profissional, em prol de alcançar certa veracidade nas encenações artísticas, esse recurso não parece limitado exclusivamente ao espaço cênico. Pelo contrário, assim como a capacidade de representar (descrita no item 1.2), também a memória afetiva é ilustrada como uma característica humana geral. Partindo, então, do pressuposto que, como afirma Stanislavski, o indivíduo comum possui a capacidade de recortar da realidade o que lhe parece importante (a memória afetiva ou a experiência prévia), não poderíamos pensar que ela se aplica tanto a um espetáculo teatral quanto às "encenações de si mesmo" das quais se compõem os RPs? Mesmo que esse indivíduo nunca tenha vivido determinada situação ou que a proposta do pesquisador seja, como vimos, distante de sua realidade, a partir do momento que ele só pode escolher como vai agir de acordo com um repertório composto apenas pelo que já viu ou viveu, a encenação se daria justamente na aplicação desses recortes de realidade aos contextos propostos, segundo o que ele acredita ser adequado.

Aliás, a questão das escolhas feitas pelos seres humanos no momento de elaborar seu papel e a adequação que eles fazem de suas próprias experiências prévias ao contexto que 
devem encenar é um ponto a se considerar, já que, tentando obter representações teatrais mais naturais, os atores escolhem, a partir dessas experiências, elementos que consideram congruentes e os aplicam de modo aproximativo a um novo contexto. Se isso, de fato, acontece, não poderia a representação de um RP não só ocorrer da mesma forma, mas, talvez, até indicar, em uma projeção futura, a maneira como tal sujeito agiria se a situação fosse real? O próprio fato de o participante escolher encenar de determinado modo por acreditar ser a maneira mais adequada ao contexto indicaria que a tendência de comportamento se confirmaria na realidade.

Na obra de Stanislavski, a adequação, por parte do ator, de elementos retirados da realidade, é um dos motores para atingir um alto grau de naturalidade ${ }^{13}$ das encenações. Além disso, a adequação de produções linguísticas ao contexto é um tema recorrente também na Linguística, tanto que sobre isso Hymes, abordando justamente a questão da relação entre língua e contexto, coloca que

(...) os usuários de uma língua são, de fato, capazes de julgar a adequação entre signo (ou mensagem) e contexto. Na verdade, de um ponto de vista geral, essa habilidade geralmente subsume ou permeia o resto, uma vez que cada julgamento de aceitabilidade ocorre em alguma situação comunicativa, ou ato de fala, de modo que uma mudança pode afetar o julgamento.

$[(\ldots)$ users of a language are indeed able to judge appropriateness between sign (or message) and context. In fact, from a general viewpoint, this ability mostly subsumes or pervades the rest, since each judgment of acceptability occurs in some speech situation, or speech act, such that a change can affect the judgment.] (1964, p. 40)

A adequação ao contexto não é, portanto, só uma habilidade geral e intrínseca à interação, mas é também o que guiaria tanto a ação quanto o julgamento dos indivíduos, no que diz respeito ao que é ou não aceitável em determinado contexto e, portanto, pode ser considerado "natural", inclusive, em uma situação encenada como a de um RP.

\subsection{A língua na "representação de papéis": algumas vozes da Linguística}

Embora, como vimos, a crítica ao RP parta da ideia de oposição entre representação e realidade, se verificarmos o modo como a interação entre falantes tem sido explicada por linguistas, podemos perceber o caráter de representação dessa interação, presente em debates

\footnotetext{
${ }^{13} \mathrm{O}$ trabalho de Stanislavski representa um marco na história da encenação moderna e um dos motivos é a alta qualidade de suas peças. Ao propor um tipo de teatro chamado posteriormente de "teatro naturalista" ou, em alguns casos, "teatro realista", o diretor buscava representar no palco a realidade da época, da forma mais fiel e genuína possível (GUINSBURG, 1985), objetivo que atingia a partir de técnicas e de um treinamento preciso e incansável de seus atores.
} 
centrais da área, como o da concepção de competência comunicativa de Dell Hymes (1972) ou aqueles sobre os rituais de cortesia e proteção da face, delineados por Penelope Brown \& Stephen C. Levinson (1987).

Observando essas e outras teorias, podemos perceber que, embora a encenação seja raramente mencionada de forma explícita entre linguistas, analisar, a partir dessa perspectiva, interações que ocorrem por meio da fala parece ser um caminho possível e, talvez, necessário. Vejamos, por exemplo, o que afirma Caffi (2009), falando de Pragmática:

os sujeitos da Pragmática (...) têm uma identidade múltipla, não só linguística, ligada aos papéis atualizados a cada vez; são sujeitos em contínua construção, não só isso, são sujeitos que se constroem justamente através dos seus discursos (...) dependendo de sua interpretação do papel desempenhado a cada vez.

[i soggetti della pragmatica (...) hanno un'identità plurima, non soltanto linguistica, legata ai ruoli di volta in volta attualizzati; sono dei soggetti in continua costruzione, non solo, sono dei soggetti che si costruiscono proprio attraverso i loro discorsi (...) a seconda della loro interpretazione del ruolo di volta in volta svolto.] (CAFFI, 2009, p. 56)

A autora estabelece uma relação entre as interações cotidianas, realizadas por meio da língua, e a representação ou a "interpretação de papéis", como ela diz, que deve ser considerada constitutiva dos sujeitos. Além disso, assim como na obra de Goffman (1975 [1959]) ou na visão dos artistas, a autora explica que o ser humano comum, aquele que deve ser analisado pela perspectiva da Pragmática, é um ser múltiplo, justamente porque representa uma variedade de papéis, construídos - também linguisticamente - na interação.

Escolhemos, portanto, como nos comunicar e podemos "adaptar" nosso discurso para, por exemplo, nos aproximarmos ou distanciarmos do nosso interlocutor, ou ainda decidimos utilizar registros mais formais em determinadas situações e menos formais em outras. Nossas escolhas linguísticas contribuem para a elaboração de "máscaras", cada uma representando uma parte de nós mesmos, que se adapta a contextos sociais específicos a fim de atingir determinados escopos comunicativos.

A mesma ideia é defendida também por Hymes (1972), que, dialogando com a teoria dos atos de fala de Austin (1962) e com o trabalho de Goffman, sobretudo no que diz respeito 
à ideia de representação ${ }^{14}$, desenvolve o conceito de competência comunicativa, definida como capacidade inata de se comunicar de modo eficaz. Para Hymes, a competência comunicativa envolve, de fato, muito mais do que o conhecimento relacionado aos componentes formais ou à dimensão sintática e semântica da língua. Na competência comunicativa está contida também a habilidade, que o indivíduo adquire durante a vida, de empregar esses e outros elementos, adequando-os aos vários contextos comunicativos, que, lembremos, são construídos, tanto a partir das características de situações e ambientes, quanto com base na relação entre interlocutores.

Outra área da Linguística que estuda a interação entre falantes e pode ser descrita do ponto de vista da representação é a Politeness Theory, elaborada por Brown \& Levinson (1987). Assim como nos estudos de Hymes (1972), um dos elementos centrais dessa teoria também se fundamenta na obra de Goffman, mas, nesse caso, mais especificamente na noção de face ${ }^{15}$, proposta no texto de 1967. Goffman (2011 [1967] descreve a face como "o valor social positivo que uma pessoa efetivamente reivindica para si mesma através da linha que os outros pressupõem que ela assumiu durante um contato particular" ou ainda como "uma imagem do eu delineada em termos de atributos sociais aprovados" (p. 15-16). Em sua visão, portanto, face é não só a "versão" de nós que representamos para o interlocutor, mas aquela que ele aceita como realidade, ao menos, enquanto a interação estiver acontecendo.

A partir dessa ideia e considerando que esse valor reivindicado não é estável, já que a face pode ser ameaçada ou perdida durante a interação, Brown \& Levinson (1987) indicam que os falantes vão interagir a partir de duas motivações ${ }^{16}$ diferentes, permeando seus discursos com estratégias de proteção da face como a cortesia, a fim de não perder ou manter e até melhorar seja a própria imagem, seja a do interlocutor. Como afirmam Brown \& Levinson, partindo da obra de Goffman: “(...) face is something that is emotionally invested, and that can

\footnotetext{
${ }^{14}$ Hymes usa o termo original em inglês "performance", escolhido por Goffman (1959), para se referir ao conceito de representação que descrevemos no item 1.2.1.

15 O conceito de face, traduzido do inglês "face" e descrito na obra de 1967, se relaciona ao conceito de fachada pessoal descrito por Goffman no texto de 1975 [1959] (ver §1.2.1), na medida em que ambos podem ser identificados como a máscara do indivíduo, construída na interação e em um ambiente ou situação específicos. No âmbito da Linguística, o termo mais utilizado e já cristalizado é "face", já que as teorias linguísticas foram formuladas, considerando prioritariamente o texto de 1967, intitulado "On face work".

16 Tais motivações são (i) "o desejo de todo 'membro adulto competente' [de um grupo ou sociedade] de que sua ação não seja impedida por outros" ["the want of every 'competent adult member' that his action be unimpeded by others] a qual os autores chamam de "face negativa"; (ii) o "desejo de 'cada membro' de que suas vontades sejam aceitas ou desejáveis para, pelo menos, alguns dos membros do grupo" ["the want of every member that his wants be desirable to at least some others"] (BROWN \& LEVINSON, 1987, p. 311), chamada "face positiva". Em outras palavras, toda interação entre falantes vai ser guiada seja pela necessidade de liberdade de escolher como agir (face negativa), seja pela necessidade de pertencimento ao grupo (face positiva).
} 
be lost, maintained or enhanced, and must be constantly attended to the interaction" ["(...) a face é algo que possui um investimento emocional, pode ser perdida, mantida ou aprimorada, e deve ser constantemente considerada na interação"] (1987, p. 311). Esses mecanismos são especialmente delicados com os ditos atos ameaçadores da face [Face Threatening Acts FTAs], entre os quais estão, por exemplo, ordens e pedidos. À variedade de atos de fala presentes em todos os tipos de interação correspondem também múltiplas estratégias de proteção da face, as quais podem ser vistas como escolhas dos indivíduos que contribuem para a construção das imagens representadas.

Existem diferentes fatores que influenciam a escolha da estratégia a ser utilizada e, portanto, o que dizer e de que forma para obter o que se deseja, "mantendo ou aprimorando" a própria imagem na interação. Entre os fatores principais, estão a "dificuldade" de realizar o ato, chamada pelos autores de "grau de imposição" (GI), e a proximidade que o falante reconhece ter com o seu interlocutor, denominada "distância social" (DS). Deste modo, em um pedido feito a um interlocutor desconhecido, o indivíduo tenderá a utilizar um maior número de estratégias em relação ao que faria com alguém muito próximo, assim como com um grau de imposição alto, isto é, que exige um esforço maior por parte do interlocutor (por exemplo, pedir um celular emprestado), também haverá uma adequação à situação.

Em outras palavras, podem ser acrescentados a um ato de fala como o pedido elementos linguísticos que o façam parecer menos impositivo e que, paralelamente, façam o falante parecer mais preocupado com o seu interlocutor. Por isso, mesmo falando com um amigo, ao invés de dizer "Me empreste o celular", é provável que a preferência seja dizer "Você me emprestaria o celular, por favor? Vai ser rapidinho". Se, porém, nosso interlocutor é alguém desconhecido, para pedir um celular emprestado, seria quase certamente utilizado um número de estratégias ainda maior, produzindo algo como por exemplo "Com licença, desculpe o incômodo. Preciso pedir um grande favor. O senhor poderia me emprestar o celular rapidinho? Preciso fazer uma ligação muito urgente e meu celular não sei por que não funciona. Eu pago a ligação".

O aumento do número de estratégias contribui para a construção de um interlocutor "educado" e preocupado em não incomodar o interlocutor ${ }^{17}$. Na verdade, a escolha dos

\footnotetext{
${ }^{17}$ É preciso lembrar que cada cultura e cada sociedade são definidas por diferentes normas e valores. Citamos aqui traços como ser "amigável", "solícito" e "preocupado com o interlocutor", por serem valorizados positivamente no Brasil. Para estudar questões dessa natureza, o Grupo de Pesquisa "Pragmática (Inter)linguística, cross-cultural e intercultural" (CNPq - https://www.gppragmatica-usp.com/) compara atos de fala em diferentes línguas e
} 
elementos linguísticos feita pelo falante tem também - ou talvez sobretudo - a motivação de atingir o objetivo (o escopo comunicativo) de "conseguir um celular emprestado". Cabe, todavia, considerar que se cotidianamente fazemos escolhas linguísticas para parecermos “amigáveis", "preocupados", "solícitos", “corteses”, é para construir imagens de nós adequadas ao contexto e, portanto, na representação da interação, com chances maiores de serem aceitas pelo nosso interlocutor.

Aliás, segundo Goffman (1981), aquilo que falamos e os papéis que representamos nos foram, ao menos parcialmente, apresentados por outras pessoas e em outros momentos. Se, por exemplo, estamos na rua, atrasados para um compromisso inadiável como buscar um amigo no aeroporto, percebemos que o celular não funciona e precisamos encontrar uma solução para falar com esse amigo, é o nosso repertório tanto de ações vividas, quanto observadas que nos oferecerá modelos para definir como agir e o que dizer (ver $\S 1.2 .1$ ). Por isso, durante uma interação, além de elaborarmos imagens de nós mesmos por meio da língua, com base no contexto, frequentemente também reproduzimos ou reencenamos fragmentos de outros contextos e de outras representações, sejam elas nossas ou de interlocutores com os quais nos relacionamos no passado. A partir dessa reflexão, o autor afirma o seguinte: "profundamente incorporados na natureza da fala, estão os requisitos fundamentais da teatralidade" ["deeply incorporated into the nature of talk are the fundamental requirements of theatricality"] (GOFFMAN, 1981, p. 4), o que significa dizer que mesmo a língua "real” é representação e possibilita a encenação de papéis. Ainda sobre isso, Goffman (1975 [1959]) explica que todos os indivíduos têm a capacidade de acessar e reproduzir papéis vividos no passado, alternando, quando necessário, entre as "máscaras" que já representaram e aquelas que outros representaram em sua presença.

\subsection{A vida real na arte: um paralelo entre role play e técnicas artísticas}

Nos RPs, um dos principais objetivos é, como vimos, tentar reproduzir e captar a "realidade", buscando representar ações cotidianas que sejam naturais e adequadas ao contexto. Aos informantes pede-se que ajam como agiriam, se estivessem, de fato, na situação proposta e parte-se do pressuposto de que é possível, embora com algumas limitações, coletar desse modo dados que possam ser utilizados para pesquisa.

culturas, concentrando-se atualmente nos pedidos. Na taxonomia desenvolvida pelo grupo, são classificadas as estratégias utilizadas nos corpora, coletados, por enquanto, em português brasileiro, italiano, espanhol argentino, alemão e francês. 
Por outro lado, como se lê no Dicionário de Teatro, nas artes, "o natural, ainda que criado pelo homem, nega-se como produção artificial e designa os 'objetos artificiais' que se apresentam a nós, como se a arte não houvesse em absoluto se misturado a eles, e como se fossem produções da natureza"' (PAVIS, 1997, p. 260), além disso, “cada modo de atuar julgase natural e pretende, a cada vez, inventar a representação verdadeiramente natural" (p. 260). O que acontece, então, é que as artes, em suas diferentes vertentes, reivindicam o status de naturalidade, mesmo reconhecendo que seja necessário partir de medidas artificiais.

Já dissemos que a busca artística por representações mais naturais perpassa de maneira significativa a obra de Stanislavski, da qual é, inclusive, uma das motivações centrais. As pesquisas do diretor russo visavam a uma representação confiável da realidade em âmbito teatral (GUINSBURG, 1985) e, para isso, ele partia do estudo da memória como elemento comum a todos os seres humanos. Além das explicações sobre o funcionamento da memória nas encenações ( $\$ 1.2 .1$ ), uma das práticas que o diretor empregava na preparação dos atores e que está diretamente ligada ao funcionamento da memória - nos interessa de modo particular e é descrita da seguinte maneira:

A técnica "como se" usa a faculdade mental de abstrair, de ir além da realidade imediata. Os sinais verbais e as demonstrações concretas memorizadas, todo o complexo de representações ligadas à personagem interpretada, o artista não se opõe à realidade, mas a acrescenta. "sim, sou Petrov, um ator" - o intérprete nunca deixa de ser consciente - "mas se eu estivesse no lugar de Hamlet, faria isto e aquilo". Quanto mais atenção o ator focaliza em suas próprias ações, realizadas em nome do personagem representado, mais ele se sentirá aquele personagem, menos ele se lembrará de si mesmo como um homem-artista.

La tecnica del "come se" utilizza la facoltà mentale di astrarre, di prescindere dall'immediata realtà. I segnali verbali e le dimostrazioni concrete memorizzate, l'intero complesso delle rappresentazioni collegate al personaggio interpretato, l'artista non si oppone alla realtà, ma la mette in aggiunta. "sì, io sono Petrov, un attore" - l'interprete non cessa di essere consapevole - "ma se fossi al posto di Amleto, farei questo e questo". Più attenzione dirigerà l'attore sulle proprie azioni, svolte per conto del personaggio rappresentato, più sentirà di essere quel personaggio, più di rado si ricorderà di sé in quanto uomo-artista. (SIMONOV, 2018 [1962], np)

Como podemos perceber, a técnica conhecida também como "o se mágico" é o que induz o ator preparado por Stanislavski a agir ou encenar, a partir de sua própria experiência em situações reais, e que é capaz de fazê-lo, inclusive, sem negar a realidade imediata da representação. Ainda de acordo com o que é explicado, a encenação por meio dessa técnica se basearia em processos mentais que mantêm o ator consciente da realidade imediata, sem, porém, que ele esteja limitado apenas ao tempo e ao espaço da própria encenação. O resultado 
do uso do "como se" seria, portanto, uma aproximação mais natural com o personagem, enquanto as circunstâncias parecem ser o "motor" que ativa a memória emocional.

É necessário dizer que as circunstâncias dadas nesse tipo de representação teatral estão ligadas a um texto dramático específico e detalhado que pertence a um personagem; além disso, tanto o texto quanto as características do personagem são geralmente criados por um autor. Já no que diz respeito aos RPs, a "máscara" a ser elaborada é sempre a do próprio indivíduo com base em um roteiro com informações, em geral, limitadas ao ambiente, ao tipo de relação entre os interlocutores e à situação de comunicação que se deve encenar, conjunto de informações que, em Linguística, foi chamado de setting (ver § 1.1). Podemos, porém, perceber a semelhança entre o modo encontrado por Stanislavski de captar a realidade e o que é desenvolvido nos estudos que utilizam os RPs, os quais também, em certo sentido, propõem que se parta de um "como se". Todavia, enquanto, em contextos de pesquisa, critica-se a encenação - sobretudo aquela realizada com base na imaginação de papéis e situações nunca vividas - que alteraria a realidade e seria incapaz de fornecer dados "confiáveis", para a arte, a encenação (gestos, sinais verbais etc.), proveniente do "como se", apenas acrescentaria elementos a essa realidade, sem negá-la. Por isso, instruindo seus atores, o diretor indica:

Sempre e eternamente quando estiver em cena você terá de interpretar a si mesmo. Mas isso será numa variedade infinita de combinações de objetivos e circunstâncias dadas que você terá preparado para seu papel que foram fundidos na fornalha da sua memória de emoções. É este o melhor e o único material verdadeiro para a criatividade interior (STANISLAVSKI, 2008 [18631938], p. 217)

Como descrito, nas encenações artísticas, mesmo os personagens, que geralmente são elaborados por terceiros, seriam, na verdade, também representações do próprio ator, o qual acrescentaria ao seu recorte da realidade traços do papel a ser colocado em cena com base no texto dramático. Parte-se, então, do pressuposto que só é possível representar versões de si e que nem circunstâncias desconhecidas, nem a existência de um papel podem cancelar a realidade que o indivíduo traz consigo no momento da encenação. Trata-se de algo parecido ao que ocorre nos RPs, nos quais, partindo de uma técnica semelhante, o sujeito é levado a atuar, mas, inevitavelmente, utilizará, ao mesmo tempo, sua própria realidade.

Uma diferença fundamental entre as "circunstâncias dadas" de peças teatrais tradicionais e aquelas que servem para a elaboração dos RPs é que, enquanto as primeiras são parte de um texto dramático mais detalhado, nos RPs essas circunstâncias são o próprio roteiro ou setting, pensado para ser genérico e compreensível para o participante. 
No teatro, o roteiro é um dos elementos basilares de uma grande variedade de obras cênicas de diferentes vertentes e existe, ao menos, desde a Commedia dell'Arte ${ }^{18}$, precursora do que conhecemos por teatro moderno. Nesse tipo de espetáculo, podem ser identificados exemplos de encenação e interação entre público e atores, nas quais a língua disposta como texto recitado não era o elemento mais importante. Na montagem das peças, a principal característica era a ausência do texto dramático, que resultava em um espetáculo constituído a partir de indicações aos atores, uma vez que

a Commedia dell'Arte não se baseava nas regras do teatro clássico, que previa um texto redigido em sua inteireza: em geral os atores combinavam as falas para cada ocasião, em torno de um tema preestabelecido, um 'roteiro' ou 'cenário' mais conhecido como canovaccio. (BARNI, 2008, p. 49)

Tendo isso em vista, o canovaccio ou roteiro é um dos componentes fundamentais desse gênero de teatro e, também nesse caso, era composto por indicações de cenários, de situações e de ações a serem desenvolvidas pelos atores. Aliás, com a compreensão por parte do público não ancorada diretamente à língua que o ator utilizava na hora do espetáculo ${ }^{19}$, muitas vezes, os personagens representados eram reconhecidos pelo espectador não por causa do texto, mas por incluírem traços comuns à sociedade da época que definiam os personagens, posteriormente denominados personagens-tipo: meninos pobres, senhores ricos, doutores da lei e casais apaixonados. Uma vez que o espectador via em cena não o Doutor 20 “real", mas a representação de um elemento da sociedade reconhecível como Doutor, era capaz, auxiliado pelo contexto, de entender a história. Era, então, o roteiro que transformava esquetes improvisadas em espetáculos e fazia de pessoas comuns atores ${ }^{21}$. A nós serve considerar que, analogamente ao canovaccio, os roteiros desenvolvidos para os RP parecem não só essencialmente compostos

\footnotetext{
${ }^{18}$ A Commedia dell'arte é uma forma de teatro que nasceu na Itália em meados de 1600 e tem por características principais a ausência do texto dramático, a construção de narrativas baseadas em personagens marcados, representando tipos presentes na sociedade. Era inicialmente feita por pessoas comuns, uma vez que nasce antes da profissionalização do ator, mas ficou famosa justamente pelo alto grau de técnica e profissionalização dos atores que, repetindo as encenações nas caravanas que costumavam fazer, iam se tornando atores excelentes, do ponto de vista da técnica da encenação.

${ }^{19}$ É preciso lembrar que as companhias faziam longas viagens e representavam países de idioma diferente daquele falado pela companhia.

${ }^{20}$ Trata-se de um personagem típico da Commedia dell'Arte que representava o rico "senhor de leis", isto é, o estudioso de direito da Università di Bologna, a mais antiga da Europa. Era geralmente caracterizado com traços de homem mais velho, rico e "barrigudo" para expressar fartura, contrapondo-se a personagens, que representavam camadas mais pobres da sociedade.

${ }^{21}$ A profissão de ator surge justamente a partir da Commedia dell'arte, com a união de indivíduos que começavam a se organizar em pequenos grupos, financiados pelos nobres para entreter suas festas. Foi nesse contexto que a arte de representar papéis passou a ser reconhecida como profissão, com a criação do primeiro tratado, que regulamenta o trabalho do artista em uma companhia de teatro. (BARNI, 2008, p. 46-47)
} 
da mesma forma - exceto pela ausência de um personagem - mas também permitem que pessoas comuns atuem em papéis sociais e cenas cotidianas.

Se observarmos concomitantemente a função dos roteiros e a encenação realizada por "não atores" em movimentos artísticos mais atuais, encontraremos a combinação desses dois elementos utilizada de diversas maneiras, como no caso do teatro de Boal, o "Teatro de Pessoas Reais" e da Performance. Enquanto Boal propunha a encenação de "não atores" partindo, da observação e representação de problemas cotidianos tirados de notícias de periódicos (técnica chamada Teatro-Jornal $)^{22}$, a primeira de suas técnicas de trabalho com "não atores", nas outras duas vertentes, não há nem representação de personagens, nem o intuito de promover encenações mais "fiéis" à vida, mas busca-se captar a realidade do indivíduo, a fim de transformá-la na própria obra de arte. Por isso, descrevendo a relação entre movimentos teatrais tradicionais e obras performativas contemporâneas, Carlson explica:

Seus praticantes, quase que por definição, não baseiam seu trabalho em personagens previamente criados por outros artistas, mas em seus próprios corpos, suas próprias autobiografias, suas próprias experiências, numa cultura ou num mundo que se fizeram performativos pela consciência que tiveram de si e pelo processo de se exibirem para uma audiência. (CARLSON, 2010, p. 17)

Com movimentos dessa ordem, práticas cotidianas, antes representadas de maneira realista, como no trabalho de Stanislavski, passam a ser colocadas, de fato, em cena, por meio do trabalho de artistas e companhias, que propositadamente constroem seus espetáculos a partir da vivência de "não atores". Tanto na Performance quanto no teatro que coloca em cena "pessoas reais" 23 , busca-se, portanto, reconfigurar a relação entre arte e vida ou, em casos mais extremos, "romper com a representação" (MENDES, 2017, p. 32) da vida pela arte. Desse modo, ambos têm como uma de suas características a substituição de histórias e personagens inventados por ações cotidianas e a presença do próprio indivíduo que as realiza na vida. Explicando especificamente o teatro feito por pessoas reais, Mendes afirma que se trata de uma

\footnotetext{
22 “'O Teatro-Jornal foi o primeiro experimento nesse sentido, desenvolvido por Boal na última fase do Teatro de Arena, fim dos anos 60 e início dos 70, como forma de sobrevivência à censura imposta pelo regime militar.' (ANDRADE, 2011, p. 2). Com essa técnica "ao invés de dizer através da arte o que o público deve fazer, Boal procura fazer com que as pessoas façam a sua própria arte.' (ANDRADE, 2011, p. 3)

${ }^{23}$ Utilizando uma das definições de Garde (2016) para o termo "real people", podemos considerar o seguinte: "Por 'pessoas reais' entendemos também aquelas pessoas em um contexto de teatro que apresentam aspectos de si mesmas - suas perspectivas, histórias pessoais, narrativas, conhecimentos, habilidades, ambientes, mundos sociais e / ou categorias sócio-econômicas - em vez de personagens fictícios ou inventados." ["By 'real people' we also mean those people in a theatre context who present aspects of their own selves - their perspectives, personal histories, narratives, knowledges, skills, environments, social worlds, and/or socio-economic categories - rather than those of fictional or devised characters."] (p. 5).
} 
“estratégia que estabelece uma zona híbrida de conexão entre teatro e realidade"” (2017,p. 14). Podemos observar exemplos de obras classificadas como "Teatro do real" no trabalho do coletivo teatral suíço-alemão Rimini Protokoll, fundado em 2002 por Stefan Kaegi, Daniel Wetzel e Helgard Haug, no Instituto de Estudos de Teatro aplicado da Universidade de Giessen (Alemanha). Para elaborar os espetáculos, o grupo parte justamente da combinação entre roteiros e indivíduos comuns, os quais denomina “especialistas do cotidiano'. Esse termo foi criado pelo próprio coletivo e é utilizado para "não tratar os participantes por aquilo que não são" (MENDES, 2017, p. 181), como acontece quando se diz "não ator" "24, denominação utilizada por Boal (2015), ou “ator não profissional”. A utilização de "especialistas do cotidiano" permite, ao contrário, evidenciar o conhecimento de mundo dos indivíduos.

A denominação seria, aliás, particularmente adequada para os participantes de RPs como aqueles que analisamos neste trabalho, pois eles são escolhidos por serem “especialistas", no nosso caso, enquanto falantes nativos ${ }^{25}$ e "representantes" de uma língua e uma cultura. É justamente a partir de tal experiência na língua materna que se busca observar como as interações são produzidas nessa língua e cultura.

Para ilustrar o modo de trabalho do coletivo Rimini Protokoll, podemos citar um de seus espetáculos, desenvolvido em parceria com os "especialistas". Nesse espetáculo, transportouse para o espaço cênico a experiência real de pessoas específicas, que contavam suas histórias, enquanto realizavam ações que lhes eram cotidianas. Vejamos a descrição da cena realizada, por exemplo, por um criador de galinhas que relata sua rotina:

Peter Heller sobe ao palco, projeta imagens de seus animais de criação, enquanto relata detalhes técnicos e triviais relacionados à sua atividade. Nesse trabalho inaugural com um especialista, o documental e o ordinário se entrelaçam a partir da operação ready-made de 'importar' um tipo de atuação previamente existente no cotidiano. (MALZACHER, 2007, p. 179 apud MENDES, 2017, p. 179)

\footnotetext{
${ }^{24}$ Embora tenhamos acordo com o termo "especialistas do cotidiano" que inclusive é capaz de ilustrar a ideia central do presente trabalho, por ser uma pesquisa que busca criar um diálogo entre áreas diferentes do conhecimento, optou-se por manter o termo "não ator" que é mais conhecido, a fim de manter a clareza do texto ${ }^{25}$ Entendemos que tanto a noção de língua quanto a de falante nativo são necessariamente abstrações, cuja definição apresenta sempre questionamentos e que é difícil delimitar (VERSCHUEREN, 2016). Consideraremos aqui falante nativo aquele que usa a língua em análise como língua materna. Nas pesquisas, busca-se, além desse critério geral, adotar outros como ter nascido, ter sido escolarizado e viver em um determinado país, em que se utiliza uma determinada língua para a comunicação. Sabemos que as situações reais são muito mais complexas do que isso e que variedades de uma mesma língua e/ou outras línguas e dialetos convivem em muitas ocasiões, mas, sem esse tipo de abstração, não haveria como estabelecer recortes de pesquisa e seriam inviáveis coletas de dados, análises e comparações.
} 
Como podemos observar, o que ocorre no cotidiano é transferido para o palco, a partir de um relato improvisado de uma situação específica e da repetição das ações que geralmente compõem essa situação, agora "revivenciadas" pelo mesmo indivíduo no contexto artístico. Com efeito, segundo Garde (2016) "o teatro de pessoas reais é um dos muitos fenômenos teatrais que oferecem conexão direta e encontro com a manifestação da realidade passada e presente" ["theatre of real people is one of many theatre phenomena that offer direct connection and encounter with manifestation of past and present reality"] (p. 69). Para a presente pesquisa, cabe ainda perceber que a combinação dos "especialistas" com o uso de elementos da vida rotineira, empregados pelo coletivo por meio de roteiros prévios (MENDES, 2017), é recurso capaz de reconstruir a realidade dentro da obra de arte. Deste modo, também nesse tipo de trabalho, a realidade não poderia ser negada pela situação de performance ou "reencenação". De fato, o indivíduo real repete no palco ações de sua própria vida e, além disso, a realidade parece estar no que o indivíduo acessa de sua própria vida para poder performar e também no próprio momento em que está "reencenando" seus movimentos. Aliás, Schechner (2006) afirma que, mesmo a repetição ou "reapresentação" de movimentos, não é uma característica exclusiva da performance, mas - diz o autor, retomando Goffman - seria o que constitui a própria vida.

Na obra intitulada Home Visit Europe (Europa em casa) $(2015)^{26}$, na qual o grupo Rimini Protokoll também coloca em cena "especialistas do cotidiano", a relação entre esses indivíduos e o roteiro se torna ainda mais evidente. No processo, que é um híbrido entre jogo, teatro e performance, uma média de 15 participantes por vez interagem guiados por uma espécie de "máquina de roteiros". Para que o espetáculo ocorra, um dos participantes decide previamente hospedar essa performance em sua casa, podendo convidar 1 ou 2 amigos para participar. Os outros participantes, ao adquirirem o ingresso, recebem indicações de onde a performance ocorrerá e, a partir dessas indicações, chegam à residência da pessoa que decidiu hospedar o espetáculo. No site do grupo, é indicado que os requisitos para hospedar o espetáculo são poucos: um forno para assar um bolo durante o espetáculo (que, depois de assado, será também utilizado ao final), uma mesa e cadeiras para 15 pessoas.

O jogo começa com todos os participantes sentados em volta da mesa, na qual estão dispostos elementos como um mapa da Europa e giz de cera, além a máquina de roteiros que

\footnotetext{
${ }^{26}$ Uma breve explicação do jogo performativo, bem como a documentação em filme e o resultado das votações feitas pelos participantes nos mais de 400 apartamentos europeus, podem ser acessados a partir do link: https://www.homevisiteurope.org/pt/index.php?id=9 (último acesso em: 17/03/2021). "Europa em casa" é a tradução em português do título do espetáculo.
} 
percorre toda a extensão da mesa, distribuindo de modo alternado aos participantes pequenas notas compostas por perguntas sobre experiências reais, indicação de ações a serem realizadas e também descrição de situações a serem discutidas pelos participantes. O processo é dividido em 5 etapas e os participantes, que em princípio respondem individualmente às questões, em determinado momento, são divididos em grupos, a partir de uma indicação dada pela própria máquina de roteiros. Cada etapa confere aos grupos uma pontuação que, ao final, lhes permitirá obter uma determinada fatia do bolo, correspondente em porcentagem ao número de pontos obtidos.

Como dissemos, nos mini-roteiros, emitidos pela máquina, alternam-se perguntas sobre experiências pessoais, a opinião que os participantes têm sobre um determinado tema (geralmente, de caráter político e/ou social) e também a indicação de ações como, por exemplo, "colocar o bolo no forno". Há ainda o pedido para que votem, julgando se determinados comportamentos ou opiniões dos outros participantes são aceitáveis ou não. No caso de Europa em casa, o fio condutor dos roteiros é a história política e social da Europa, ligada a questões como imigração e fronteiras. Além disso, o espetáculo se constrói a partir da experiência de vida dos participantes, que respondem perguntas, interagem e "encenam a si mesmos" para os outros participantes. Outro aspecto é que não só a encenação é algo realizado por todos, mas há também a avaliação do comportamento dos outros, que ocorre por meio de votações eletrônicas (com o auxílio de alguns tablets).

É importante notar que, embora a máquina guie o percurso do jogo através das notas emitidas, os participantes decidem de maneira autônoma como vão responder e realizar as ações, o que faz de suas experiências uma parte importante da construção do espetáculo. Ora, uma vez que o "julgamento" das respostas ou performances dos outros participantes também ocorre às vezes de maneira autônoma e às vezes coletivamente, o que, na verdade, parece guiar o comportamento dos indivíduos é a relação social que se estabelece na interação e não a máquina e seus roteiros. Um exemplo disso acontece quando a máquina emite a nota de que todos devem ficar em silêncio até que se estabeleça coletivamente - levantando as mãos - o momento em que o grupo possa voltar a falar. O vídeo da obra mostra que, após um período de tempo inicial sem manifestações, quando o primeiro participante espontaneamente se manifesta, as mãos começam a ser levantadas, uma a uma, com um curto espaço de tempo entre a ação de um e de outro participante. O último participante, que acaba tendo a responsabilidade de permitir que todos possam voltar a falar, decide levantar a mão, mas aparenta certa contrariedade, por estar realizando a ação por pressão do coletivo. 
Considerando que tanto o comportamento quanto o julgamento são guiados pela relação que se estabelece entre os participantes, a obra parece recriar em si a atmosfera de construção de papéis cotidianos que ocorre na própria vida e confirmar, portanto, a ideia de Goffman (1975 [1959]), de que o que guia a construção de nossas representações e como agimos é, na verdade, a interação com os nossos interlocutores e o contexto em que nos encontramos.

Transpondo mais uma vez o roteiro e a atuação de "especialistas" para o contexto de criação de RPs do tipo considerado aqui, podemos pensar que, embora os roteiros organizem as ações desenvolvidas pelos participantes, não são eles que determinam como os participantes se comportam. O que guiaria a improvisação nas situações dadas, seria, na verdade, o ambiente e, em especial, a relação que se estabelece entre os interlocutores, assim como vimos ocorrer no trabalho artístico.

Contrapondo os processos envolvidos nos RPs com aqueles empregados nos espetáculos artísticos, parece ser importante considerar, um último ponto em comum entre a arte e os RPs de pesquisa, a presença de um “organizador”. Como vimos no início do presente trabalho, a questão da interferência do pesquisador - seja na preparação do roteiro, seja no momento da gravação - é vista como um indicador de distanciamento entre os dados coletados e uma interação que poderia ser considerada natural ou representativa da realidade dos falantes. Porém, para além da já citada impossibilidade de se obter dados sem interferência do pesquisador, apontada pelos próprios linguistas, podemos observar que nos espetáculos artísticos a realidade só pode ser captada a partir de uma longa preparação prévia, pensada e desenvolvida pelo artista, assim como na obra de Stanislavski ou no modo de escolher os “especialistas” e preparar os espetáculos dos diretores do grupo Rimini Protokoll. Aliás, esse tempo de preparação é, muitas vezes, mais longo e complexo do que a própria obra e isso parece ocorrer, justamente, para que a realidade a ser captada não seja cancelada ou invalidada.

$\mathrm{Na}$ medida em que a busca por captar parcelas de realidade parece ser uma das principais motivações para o uso de processos parecidos em obras artísticas e RPs de pesquisa, dada a complexidade do tema e dos campos de conhecimento envolvidos, nessa parte do trabalho, foram apenas pontuadas algumas das técnicas utilizadas para a "captação da realidade", que mostraram a necessidade de mais pesquisas que aprofundem o debate sobre representação e realidade no âmbito da Linguística e das Artes Cênicas, colocando essas áreas em diálogo. 


\section{Da teoria à percepção dos falantes: a metodologia da pesquisa}

Neste capítulo, será apresentada a metodologia utilizada para coletar e analisar os dados empíricos da pesquisa. Para a realização dessa etapa, foram criados dois tipos de questionários: (i) um teste de percepção, respondido por falantes nativos de italiano; (ii) uma entrevista retrospectiva, realizada com parte dos informantes que participaram das gravações dos vídeos selecionados. Foram entrevistados somente os "não atores", pois, como dissemos, os atores foram informados sobre a finalidade da pesquisa e, portanto, não poderiam emitir opiniões isentas.

Também conhecido como judgement test, o teste de percepção é uma forma de acessar o julgamento do informante sobre determinado elemento, transformando-o em um dado que pode ser estudado. A escolha de utilizar esse tipo de instrumento se justifica, na medida em que “dados de percepção desempenham uma função crucial em investigações linguísticas, pois fornecem informações não prontamente disponíveis em outros tipos de dado. Mais importante, eles distinguem as ocorrências possíveis daquelas impossíveis em dados não produzidos naturalmente" [Judgment data play a crucial role in linguistic investigation because they provide information not readily available from other kinds of data. Most importantly, they distinguish - possible from impossible utterances among those that have never been naturally produced.] (SCHÜTZE \& SPROUSE, 2014, p. 30). Com o teste de percepção, é possível ter acesso ao julgamento do informante que está na posição de observador, ou seja, vê os dados de um ponto de vista externo ao processo de criação do RP; por outro lado, com a entrevista retrospectiva, busca-se obter a percepção do participante do vídeo, isto é, a perspectiva interna. A vantagem de usar esse instrumento é que entrevistas retrospectivas (retrospective interviews) podem auxiliar "o pesquisador a entender melhor o que os informantes disseram, porque disseram o que disseram, e como disseram. Essas entrevistas podem fornecer informações adicionais e esclarecer algumas das decisões, escolhas e realizações do informante" [(...) may help a researcher to better understand what the informant said, why they said what they said and how they said it. Such a interview may provide additional information and may shed light on some of the informant' decision, choices and realizations] (SCHNEIDER, 2018, p.64). Funcionando, de certo modo, como o que Crookall \& Saunders (1989) chamam de "debriefing", ou seja, "o processo no qual participantes e organizador, juntos, avaliam criticamente as atividades e comportamentos da simulação" ["the process in which participants and organizer together critically appraise simulation activities and behaviours], também nas 
entrevistas " "ex-participantes' podem refletir e examinar o que aconteceu na simulação" ["(...) 'ex-participants' can reflect on and examine what happened in the simulation] (p. 17). Uma das desvantagens dessas entrevistas é, porém, o número muito limitado de informantes, o que impossibilitou a realização de um teste piloto. Já no que diz respeito ao teste de percepção, o objetivo era que ele fosse respondido por 60 falantes nativos de língua italiana (30 atores e 30 falantes nativos “não atores”). Não havendo um grupo pré-determinado de informantes, para esse instrumento foi possível realizar um piloto.

Cabe explicar que o teste piloto, realizado apenas com o teste de percepção, serviu também como uma verificação para as entrevistas retrospectivas, visto que os dois instrumentos foram elaborados com base nos mesmos princípios e apresentam propósitos semelhantes: analisar a naturalidade, a aceitabilidade e a verossimilhança dos RPs. O que muda é apenas a perspectiva a partir da qual os vídeos são observados, possibilitando a contraposição entre as percepções do observador externo e do avaliador participante (KÁDÁR \& HAUGH, 2013, p. $3)$.

Kádár \& Haugh propõem que, para se avaliar práticas sociais e questões tanto intrínsecas quanto subjetivas na comunicação, é preciso ampliar as perspectivas de como elas são compreendidas. Os autores sugerem esse modelo, em especial, para a análise da cortesia (p. 3), mas consideramos que ele possa ser aplicado com bons resultados também à nossa investigação. No modelo, existe um eixo de observação que inclui, de um lado, a chamada "primeira ordem" de análise (first order), que leva em conta a compreensão do próprio participante/metaparticipante da pesquisa (no nosso caso, os dois interlocutores que gravaram os RPs) e, de outro, a "segunda ordem" (second order), que inclui observadores externos, tanto analistas quanto avaliadores não especializados (na nossa pesquisa, falantes nativos de italiano e atores). Além disso, Kádár \& Haugh consideram a conceitualização êmica ou interna e ética ou externa e acrescentam que nenhuma dessas perspectivas se sobressai em relação às outras, pois é justamente a interrelação entre todas elas que permite a compreensão mais profunda dos fenômenos. No quadro abaixo (Quadro 2), retomamos a recapitulação da proposta, assim como foi apresentada por Santoro e Porcellato (2020): 
Quadro 2 - First order e second order de Kádár e Haugh (2013)

\begin{tabular}{|l|l|}
\hline \multicolumn{1}{|c|}{ First order } & \multicolumn{1}{c|}{ Second order } \\
\hline $\begin{array}{l}\text { (1) Compreensão do } \\
\text { participante/metaparticipante }\end{array}$ & $\begin{array}{l}\text { (3) Compreensão do analista e do } \\
\text { observador não especialista }\end{array}$ \\
\hline $\begin{array}{l}\text { (2) Conceitualização êmica (interna) e ética } \\
\text { (externa) }\end{array}$ & $\begin{array}{l}\text { (4) Conceitualização teórica (baseada } \\
\text { também na percepção dos não especialistas) }\end{array}$ \\
\hline
\end{tabular}

Fonte: Santoro e Porcellato, 2020, p. 58

Ao descrever o processo de elaboração do questionário piloto, serão explicadas as perguntas que compõem cada um dos instrumentos, bem como as referências teóricas nas quais elas se fundamentam. Após apresentar os informantes que responderam ao teste piloto, serão comentados os resultados obtidos, por meio dos quais foi possível identificar as mudanças necessárias tanto para a versão final dos questionários quanto para as entrevistas. Por fim, será descrita a metodologia utilizada para analisar ambos os instrumentos.

\subsection{0 teste piloto}

Nesta seção, será descrita a elaboração do teste piloto, partindo da seleção dos RPs a serem submetidos ao julgamento dos participantes. A seguir, será ilustrado o modo como foi definido o formato do teste, considerando tanto as perguntas com avaliação quantitativa a serem feitas aos participantes, quanto as perguntas com respostas abertas.

2.1.1 Os role plays selecionados para o teste

É preciso explicar que para escolher os RPs utilizados no presente estudo, que partem em todos os casos do ato de fala do pedido, foram consideradas duas das principais variáveis que, segundo Brown \& Levinson (1987), influenciam nas escolhas linguísticas dos indivíduos: (i) a distância social (DS) entre os interlocutores, que consideramos baixa entre amigos ou parentes e alta quando os falantes não se conhecem; (ii) o grau de imposição (GI), isto é, o quanto o ato de fala proposto - no nosso caso, um pedido - é mais ou menos "difícil" de ser realizado por parte do interlocutor, tendo em vista a relação custo-benefício entre o pedido e sua realização.

No seguinte quadro (Quadro 3), descrevemos, em um primeiro momento, apenas as situações de baixo grau de imposição (GI-). 
Quadro 3 - Descrição de situações de baixo grau de imposição

\begin{tabular}{|c|c|c|}
\hline Vídeo & Situação (GI-) & Setting \\
\hline 1 e 2 & $\begin{array}{l}\text { chegar com sede na } \\
\text { cada de um amigo e } \\
\text { pedir d'água }\end{array}$ & $\begin{array}{l}\text { Você acabou de entrar na casa do seu amigo e está com } \\
\text { sede. O que você diz? } \\
\text { [Sei appena entrato a casa di un tuo amico/una tua } \\
\text { amica e hai sete. Che cosa dici?] }\end{array}$ \\
\hline 5 e 6 & $\begin{array}{l}\text { pedir uma caneta } \\
\text { emprestada na rua }\end{array}$ & $\begin{array}{l}\text { Você está na rua e quer escrever o número de telefone } \\
\text { de um anúncio que vê passando. Você percebe, no } \\
\text { entanto, que não tem uma caneta com você. O que você } \\
\text { diz? } \\
\text { [Sei per strada e vuoi scrivere il numero di telefono di } \\
\text { un annuncio che vedi passando. Ti accorgi, però, di non } \\
\text { avere una penna con te... Che cosa dici?] }\end{array}$ \\
\hline
\end{tabular}

Cabe notar que as situações "água" e "caneta", ambas de baixo grau de imposição, variam quanto à distância social, sendo que na primeira a distância social (DS-) é baixa, já que a situação é entre amigos, e na segunda, alta (DS +), sendo que o pedido deve ser feito a um desconhecido.

Já para as situações de alto grau de imposição (GI +), temos a seguinte recapitulação (Quadro 4).

Quadro 4 - Descrição de situações de alto grau de imposição

\begin{tabular}{|c|c|l|}
\hline Vídeo & Situação (GI +) & \multicolumn{1}{c|}{ Setting } \\
\hline $3 \mathrm{e} 4$ & $\begin{array}{l}\text { Você está na rua e está atrasado. Você precisa ligar } \\
\text { pedir o celular } \\
\text { emprestado na } \\
\text { rua } \\
\text { para visitá-lo/la. Seu celular, por algum motivo inexplicável, } \\
\text { não funciona e não há telefones públicos por perto. Só resta } \\
\text { procurar alguém que empreste o celular para uma ligação. O } \\
\text { que você diz? }\end{array}$ \\
$\begin{array}{l}\text { [Sei per strada e sei in ritardo. Devi urgentemente } \\
\text { telefonare a un tuo amico che ha fatto un lungo viaggio per } \\
\text { venire a trovarti. Il tuo cellulare per qualche inspiegabile } \\
\text { motivo non funziona e non ci sono telefoni pubblici in giro. } \\
\text { Non resta che cercare un cellulare in prestito per una } \\
\text { telefonata... Che cosa dici?] }\end{array}$ \\
\hline
\end{tabular}




\begin{tabular}{|c|c|l|}
\hline 7 e 8 & $\begin{array}{c}\text { pedir uma toalha } \\
\text { ou pedir para } \\
\text { tomar um banho } \\
\text { na casa de um } \\
\text { amigo após um } \\
\text { temporal }\end{array}$ & $\begin{array}{l}\text { Você acabou de entrar na casa do seu amigo encharcado } \\
\text { porque está chovendo muito lá fora. Você precisa tomar um } \\
\text { banho ou, pelo menos, trocar a roupa molhada. O que você } \\
\text { diz? }\end{array}$ \\
& $\begin{array}{l}\text { [Sei appena entrato a casa di un tuo amico/una tua amica } \\
\text { bagnato fradicio perché fuori sta piovendo a dirotto. Hai } \\
\text { bisogno di farti una doccia o almeno di toglierti } i \text { vestiti } \\
\text { bagnati... Che cosa dici?] }\end{array}$ \\
\hline
\end{tabular}

Também nessas situações a distância social varia e é alta (DS +) nos vídeos 3 e 4, quando os interlocutores não se conhecem, e baixa (DS -), quando os interlocutores são amigos. Assim como no trabalho de Santoro (2013), na nossa pesquisa também foi mantida a distância social real entre os interlocutores e, por isso, os vídeos de falantes nativos foram gravados com 1 dupla de amigos e 1 dupla de pessoas que, de fato, não se conheciam.

Os vídeos gravados por "não atores" foram selecionados do corpus de Santoro (2012) que inclui dois atos de fala: pedidos e pedidos de desculpas. Como dissemos, decidimos variar o grau de imposição e a distância social, mas limitar nossa observação aos pedidos, já que se trata de um dos atos de fala mais frequentes nas interações cotidianas e de um dos mais estudados nas mais diversas perspectivas. Além disso, o pedido é um "ato ameaçador da face" ou Face Threatening Act (FTA), especialmente interessante porque coloca em jogo tanto a face positiva do falante quanto a face negativa do interlocutor (BROWN \& LEVINSON, 1987).

Os vídeos utilizados na pesquisa foram todos gravados em Roma, seguindo a modalidade do RP semiaberto descrita no primeiro capítulo (§ 1.1). Os quatro "não atores" são três mulheres e um homem, falantes nativos de italiano, embora, no momento em que foram gravados os RPs, alguns morassem ou tivessem morado também em outros países, como a Alemanha e o Brasil. Tinham entre 39 e 62 anos e possuíam formação superior e as seguintes profissões: tradutora e intérprete, consultora de promoção turística, professora de italiano na Alemanha e aposentado.

Os vídeos dos atores foram gravados especialmente para esta pesquisa, com base nas mesmas situações encenadas pelos "não atores". Uma dupla era composta por atores profissionais, que atuam em cinema e teatro, e uma por estudantes de teatro da Università degli Studi Roma Tre. Os participantes tinham entre 20 e 30 anos e eram de Roma ou de cidades próximas.

A escolha de reproduzir as quatro situações também com atores deveu-se à avaliação de que ter as mesmas cenas gravadas por atores e "não atores" possibilitaria comparar a 
naturalidade entre RPs de pessoas que não possuem nenhuma familiaridade com a rotina de filmagens e aqueles de pessoas que têm isso em seu cotidiano e em sua profissão. Desse modo, seria possível investigar se o julgamento de falantes confirma a ideia de que todo ser humano não só é capaz de encenar, mas o faz cotidianamente, defendida tanto na arte (BOAL, 2015; PIRANDELLO, 2018 [1927], SHAKESPEARE, 2011 [1908]) quanto em outras áreas (CAFFI, 2009; GOFFMAN, 1975 [1959]).

\subsubsection{O formato do teste piloto}

O teste piloto foi criado tendo como pressuposto teórico principal a obra de Goffman (1975 [1959]), na qual as interações cotidianas, como aquelas recriadas pelos RPs, são comparadas a representações teatrais. Desse modo, o teste parte da ideia, elucidada por Goffman, segundo a qual representações são parte do cotidiano e busca compreender como são feitas e percebidas tais representações, já que está entre os objetivos da pesquisa discutir perspectivas diferentes a respeito da ação de representar como algo presente na vida e não como uma atividade periférica e destacada da realidade.

Portanto, para averiguar se as encenações e, sobretudo, a língua dos RPs, eliciadas a partir da simulação de situações cotidianas, podem ser vista como fidedignas e verossímeis, o teste piloto foi organizado partindo, por um lado, de uma análise da situação, considerada central em qualquer interação social (CAFFI, 2009; GOFFMAN, 1975 [1959]; HYMES, 1972), e, por outro, dos elementos que, segundo as teorias que utilizamos como referência, são relevantes na composição das representações cotidianas. São eles: (i) o modo como o falante escolhe desenvolver as ações ou elabora os papéis (GOFFMAN, 1975 [1959] 1981; JUCKER, 2018); (ii) as escolhas linguísticas (CAFFI, 2009; CRYSTAL, 1997); (iii) a capacidade de representar (BOAL, 2015).

O teste foi desenvolvido na plataforma Google Forms e organizado em dois blocos de questões. O primeiro propunha uma avaliação quantitativa por meio de cinco perguntas fechadas, que solicitavam a atribuição de uma pontuação. Foi utilizada uma escala Likert com pontuação de 1 a 5 , sendo que 1 era o valor mais baixo e 5 o mais alto. Com essa parte do questionário, buscava-se saber qual a percepção dos informantes em relação à verossimilhança e à correspondência dos elementos observados nas cenas do RP, quando comparadas com aquilo que eles consideravam parte de sua realidade de falantes. Sobre o uso da escala Likert, Schutze \& Sprouse (2014, p. 33) indicam que "um dos principais benefícios da EL (Escala Likert) é que ela é numérica e intuitiva. (...) Significa que a EL pode ser usada para responder 
perguntas sobre o tamanho de uma diferença entre condições, ao possibilitar testes estatísticos inferenciais" [One of the primary benefits of LS (Likert Scale) is that it is both numerical and intuitive. (The former) means that LS can be used to answer questions about the size of a difference between conditions by leveraging inferential statistical tests] (2014, p. 33). Uma vez que, para avaliar modos e usos da língua, bem como a naturalidade com a qual essa língua é empregada, é preciso considerar também os fatores subjetivos dos indivíduos, no nosso caso, a escala Likert se torna um dispositivo bastante profícuo.

Essas perguntas deveriam ser respondidas para cada um dos oito vídeos que compõem o questionário. Para compreender melhor o modo como o teste piloto foi organizado, reproduzimos aqui um exemplo (Figura 1) relativo ao primeiro dos oito vídeos e que se repete, exatamente da mesma maneira, para cada um dos oito vídeos. 
Figura 1 - Vídeo 1: perguntas e escala Likert

Come fanno le richieste gli italiani?

Video 1

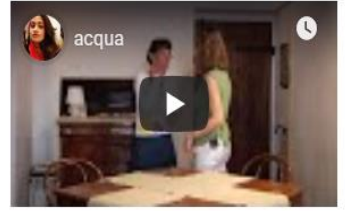

1 - Osserva con attenzione LA SITUAZIONE presente nel video. Quanto ti sembra vicina a situazioni che hai già visto/vissuto nella vita reale?*

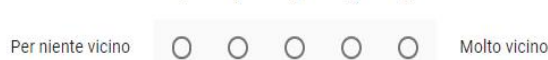

2 - Osserva ora IL MODO in cui il parlante fa la richiesta, ossia, come si muove, che atteggiamenti assume, che tono della voce ha ecc. Quanto ti sembra vicino a quello che hai già visto/vissuto nella vita reale? *

$$
\begin{array}{lllllll}
\text { Per niente vicino } & 0 & 0 & 0 & \bigcirc & \text { Molto vicino }
\end{array}
$$

3 - Prova a rivolgere l'attenzione a quello che viene detto, ovvero, alle PAROLE e alle ESPRESSIONI scelte dal parlante per ottenere quello di cui ha bisogno. In che misura ti sembrano adatte alla situazione? *

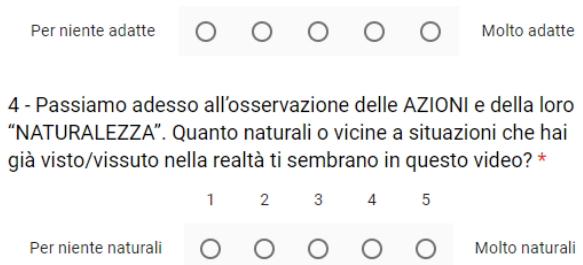

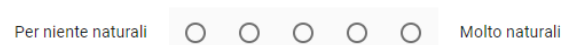

5 - Considerando che i partecipanti sapevano di essere registrati, quanto ti pare che loro fossero a loro agio nello svolgimento delle azioni proposte? *

Per niente a loro agio $\bigcirc \quad 0 \quad 0$ Molto a loro agio

Riesci a dire quali elementi ti hanno guidato al momento di attribuire il tuo punteggio? Hai ancora altre osservazioni $d a$ aggiungere sulla "naturalezza" dei video che hai visto?

O segundo bloco do teste era composto por três perguntas abertas, ou seja, por uma avaliação de tipo qualitativo. Tais questões foram criadas para deixar ao informante maior liberdade em suas considerações tanto sobre a naturalidade das ações contidas nos RPs, quanto sobre a possível diferença nas representações de atores profissionais e pessoas comuns. Em uma análise do uso de RPs em contexto específico (a sala de aula de um curso universitário de odontologia em Adelaide, Austrália), estudiosos indicaram que, em um questionário majoritariamente composto por perguntas em escala Likert e finalizado com duas questões abertas, "os comentários abertos dos alunos enriqueceram e explicaram as classifícações 
positivas" [the students' open-ended comments enriched and explained the positive ratings] (SKINNER et al., 2012, p. 893) e era exatamente esse também o nosso objetivo.

Considerando tudo isso, a formulação das perguntas abertas do teste piloto foi a que reportamos a seguir (Quadro 5).

Quadro 5- Teste piloto: perguntas abertas

Bloco 1: Avaliação quantitativa

1- Osserva con attenzione la situazione presente nel video. Quanto ti sembra vicina a situazioni che hai già visto/vissuto nella vita reale?

[Observe com atenção a situação presente no vídeo. Em que medida ela parece próxima de situações que você já viu/viveu na vida real?]

2- Osserva ora il modo in cui il parlante fa la richiesta, ossia, come si muove, che atteggiamenti assume, che tono della voce ha ecc. Quanto ti sembra vicino a quello che hai già visto/vissuto nella vita reale?

[Observe o modo em que o falante faz o pedido, ou seja, como se move, que atitudes manifesta, qual tom de voz expressa, etc. Quanto se aproxima de algo que você já viu/viveu na vida real?]

3- Prova a rivolgere l'attenzione a quello che viene detto, ovvero, alle parole e alle espressioni scelte dal parlante per ottenere quello di cui ha bisogno. In che misura ti sembrano adatte alla situazione?

[Tente voltar sua atenção ao que é dito, ou seja, às palavras e expressões escolhidas pelo falante para obter o que precisa. Em que medida a escolha lhe parece adequada à situação?]

4- Passiamo adesso all'osservazione delle azioni e della loro "naturaleza". Quanto naturali o vicine a situazioni che hai già visto/vissuto nella realtà ti sembrano in questo video?

[Em relação à "naturalidade" das ações. Quanto elas te parecem naturais ou próximas de situações que você já observou/viveu na realidade?]

5- Considerando che i partecipanti sapevano di essere registrati, quanto ti pare che loro fossero a loro agio nello svolgimento delle azioni proposte?

[Considerando que os participantes do vídeo sabiam que estavam sendo filmados, quão confortáveis em desenvolver as ações propostas eles parecem estar?] 


\section{Bloco 2: Avaliação qualitativa}

6 - Riesci a dire quali elementi ti hanno guidato al momento di attribuire il tuo punteggio? Hai ancora altre osservazioni da aggiungere sulla "naturalezza" dei video che hai visto?

[Você consegue dizer quais elementos te guiaram no momento de atribuir a pontuação? Tem ainda alguma observação que gostaria de acrescentar sobre a "naturalidade" dos vídeos que assistiu?]

7 - Alcuni dei video che hai visto sono stati registrati da attori professionisti. Riusciresti a dire quali?

[Alguns dos vídeos aos quais você assistiu foram gravados por atores profissionais. Você saberia dizer quais?]

8 - Quali aspetti ti hanno fatto decidere quali sono $i$ video registrati da attori professionisti e quali da "persone comuni"?

[Quais aspectos te levaram a decidir quais são os vídeos gravados por atores profissionais e quais por "pessoas comuns"?]

A parte das perguntas qualitativas do teste se inicia com uma questão a respeito da situação, pois se trata de um aspecto central na preparação de um RP e de um componente essencial em uma representação, seja ela do teatro ou da vida real. Na obra de Goffman (1975 [1959]), a situação está contida na noção de "fachada" e pode ser vista como algo que, em parte, cria e, em parte, deriva da interação entre dois ou mais interlocutores, guiando tanto a escolha das encenações quanto o modo como elas são performadas. Além disso, como vimos (cf. §1.2.1), a situação social pode guiar a pressuposição do indivíduo que vai começar a construir a máscara que deseja encenar, mesmo antes de estar na presença do interlocutor, com base no que ele conhece de situações parecidas. Em Hymes (1972) e Brown \& Levinson (1987), a situação em que os indivíduos interagem também é essencial para a tomada de decisão sobre como se deve agir.

Vimos que, em pesquisas linguísticas que fazem uso de RPs, a situação está contida no roteiro composto também por meio de descrições dos ambientes físicos em que ela ocorre. Mesmo com denominações diferentes, tais como "contexto", "cenário", "setting" ou ainda "situação" (BLUM-KULKA et al., 1989), a finalidade desse roteiro é sempre a de descrever um conjunto de elementos cotidianos específicos, mesmo que hipotéticos, nos quais ocorreria $\mathrm{o}$ ato de fala a ser realizado e depois analisado. Desse modo, o roteiro serve para guiar o participante a reproduzir no RP, a maneira como ele acredita que agiria se a situação proposta fosse real. 
Definido por Nickels (2006) como "o meio social da interação" ["the social milieu of the interaction"] (p. 4), o "setting" - ou melhor, a forma como ele é elaborado e utilizado - é indicado como um dos aspectos que podem distanciar a fala produzida nos RPs da língua dos contextos naturais. Isso ocorre, por exemplo, quando o participante se apoia excessivamente nas indicações escritas no roteiro, representando, assim, uma ação linguística baseada não em seus conhecimentos prévios, mas naqueles do pesquisador. Hassall (1997) observa, por exemplo, o que acontece com aprendizes de uma L2 em uma condição como a que acabamos de ilustrar, na qual eles, apoiando-se no que é descrito, produzem respostas diferentes das que pertencem à sua realidade. Afirma o autor:

(...) nos dados solicitados tanto pelos role plays quanto pelos DCTs, os alunos de L2 usaram informações da descrição das situações e, como resultado, produziram respostas mais longas e mais elaboradas do que eles fariam em situações da vida real.

[(...) both role-play and discourse completion test (DCT) request data, L2 learners used information from the description of the situations and, as a result, produced longer and more elaborate responses than they would in real-life situations.] (HASSALL, 1997 apud BATALLER \& SHIVELY, 2011, p. 18)

Veio dessas reflexões a ideia de que seria necessário investigar se as situações dos roteiros dos RPs escolhidos poderiam ser consideradas "verossímeis". Consideramos, além disso, que também em estudos sobre setting foram aplicados questionários para identificar a possibilidade de as situações sob análise ocorrerem na realidade dos informantes (NICKELS, 2006). Tendo isso em vista, decidimos utilizar a percepção de falantes nativos, pois partimos do pressuposto que, baseados em sua realidade linguístico-cultural, poderiam nos fornecer indícios para verificar se e em que medida esse aspecto influi no resultado final.

A partir da segunda questão, o elemento observado passa a ser a própria representação. Goffman inicialmente divide a capacidade humana de atuar em papéis sociais em duas atividades distintas, sendo a expressão que o indivíduo "transmite" relacionada aos elementos verbais, enquanto a expressão que ele "emite" correspondente às ações físicas (1975 [1959], p.12) (ver §1.2.1). Partindo disso, no nosso estudo, propusemos observar a representação de gestos e língua separadamente e o teste piloto abordou as ações físicas na pergunta 2 e as ações linguísticas na pergunta 3 .

Com efeito, ao estudarmos as interações humanas a fim de saber como falantes de uma determinada cultura se comunicam, precisamos levar em conta que a língua não é o único meio de transmissão de mensagens entre dois ou mais interlocutores: 
Nós colorimos e temperamos nosso discurso com uma variedade de gestos vocais, faciais e corporais naturais, que indicam nosso estado interno, transmitindo atitudes às proposições que expressamos ou informações sobre nossas emoções ou sentimentos. Embora possamos estar cientes deles, esses comportamentos geralmente estão fora do nosso controle consciente: são involuntários ou espontâneos.

[We colour and flavour our speech with a variety of natural vocal, facial and bodily gestures, which indicate our internal state by conveying attitudes to the propositions we express or information about our emotions or feelings. Though we may be aware of them, such behaviours are often beyond our conscious control: they are involuntary or spontaneous.] (WHARTON, 2009, p. 1)

Como afirma Wharton nesse trecho, também os gestos, as expressões faciais, a forma como caminhamos e até mesmo o olhar são maneiras de nos comunicarmos e, por isso, durante a preparação do teste piloto, avaliamos que seria necessário analisar tais elementos já na segunda questão, antes mesmo de tratar mais especificamente dos aspectos linguísticos.

Embora considerados geralmente espontâneos, os gestos nem sempre são movimentos inconscientes. Segundo Goffman (1975 [1959], p. 15), no momento da comunicação, esses elementos podem ser utilizados de modo mais ou menos consciente, de acordo com o escopo de quem os realiza. Além disso, como vimos ( $\$ 1.2$ ), há ainda outros fatores importantes que influenciam o agir físico e o grau de consciência do indivíduo com relação a suas ações. Tratase das regras e convenções sociais do grupo, em que esse indivíduo está inserido, e daquelas relacionadas ao papel que ele escolhe representar em determinada situação e ambiente.

Na transmissão da informação ao interlocutor durante uma interação, a parte não verbal da comunicação exerce uma função fundamental: a de colaborar para a construção do papel social representado. Tal "máscara", para ser compreendida e aceita pelo outro precisa ser desenvolvida a partir da correspondência equilibrada entre o que é "emitido" pelas ações e o que é "transmitido" verbalmente (GOFFMAN, 1975 [1959], p. 12). Sendo assim, de acordo com o autor, quanto mais coerência houver entre os dois tipos de ação, mais credibilidade esse papel expressa.

Após investigar as ações físicas desenvolvidas pelos falantes nativos nos RPs, com a terceira pergunta, propusemos aos informantes que observassem as escolhas linguísticas ou o modo como os pedidos haviam sido produzidos.

Assim como os gestos, também a língua, ou seja, o que se diz e como se diz, é parte essencial de uma interação comunicativa, sendo não só um dos elementos que compõe os vários 
papéis sociais representados cotidianamente pelos seres humanos, ou melhor, as várias versões de si (GOFFMAN, 1975 [1959]), mas aquele que nos possibilita, inclusive, encenar as palavras dos outros (GOFFMAN, 1981).

Precisamos lembrar também que os aspectos linguísticos são especialmente relevantes na nossa perspectiva, já que é justamente para estudos dessa área que os RPs são mais utilizados. Para esses estudos, principalmente aqueles desenvolvidos no âmbito da Pragmática, a noção adotada é que os falantes se constroem no discurso, a partir das escolhas linguísticas que fazem, ou seja, que os sujeitos são o resultado da maneira como se colocam linguisticamente em uma interação (CAFFI, 2006; CRYSTAL, 199).

Se para estudar línguas a partir de uma perspectiva pragmática, é preciso observar não só as escolhas dos falantes, mas também os contextos nos quais elas se inserem, ou o que Caffi chama de "agir comunicativo situado" [l'agire comunicativo situato] (2009, p. 53), para averiguar se a língua produzida por meio de RPs é verossímil a ponto de poder ser um dado relevante para as pesquisas, devemos levar em conta que o contexto no qual essa língua é produzida é justamente o setting elaborado pelo pesquisador. Por isso, propusemos com a pergunta 3 do teste piloto identificar se a fala era adequada à situação proposta.

Após averiguar em que modo gestos e língua são percebidos, nosso objetivo era saber se tais elementos influenciam a naturalidade identificada nos RPs. Por isso, na pergunta 4, o objetivo era aferir, de forma mais pontual, quão naturais parecem ser as representações, para verificar se por meio de RPs podem ser eliciados dados com características equiparáveis aos dados naturalísticos. Essa questão foi criada na tentativa de investigar o que diz a literatura consultada, segundo a qual representações verossímeis ocorrem à medida que os sujeitos estão confortáveis com as condições do ambiente e com o papel representado (GOFFMAN, 1975 [1959]; STANISLAVSKI, 2006 [1863-1938]).

Com a quinta e última questão do primeiro bloco do teste piloto, buscou-se estimular a observação do possível efeito da câmera na maneira como o participante age e fala, para perceber se ela interfere na espontaneidade das ações. A questão é, de fato, polêmica, pois, embora se acredite que a presença da câmera possa alterar o modo como os falantes proferem seus enunciados, como afirma Golato (2017), é verdade também, como aponta a mesma autora, referindo-se também ao trabalho de Kasper (2000), que "se for dado aos sujeitos um tempo, mesmo que curto, para se adaptarem, eles tendem a esquecer que estão sendo gravados" ["if 
given even a short time to adjust, subjects tend to forget that they are being recorded"] (2017, p. 23).

A ideia de incluir essa pergunta no teste piloto resultou da convicção de que as considerações do falante nativo comum, que avalia o RP do ponto de vista externo, poderiam nos fornecer informações para verificar se o que é visto como espontaneidade ou como falta dela interfere na naturalidade geral percebida nos vídeos.

Como dito precedentemente, o segundo bloco do teste piloto é formado por três questões abertas. Tendo em vista que o conceito de naturalidade não é objetivo, mas múltiplo (PAVIS, 1997), com a pergunta 6, a finalidade era captar informações mais pontuais sobre a percepção desse conceito por parte dos informantes, o que nos permitiu uma observação individual dos parâmetros utilizados por cada um deles para acessá-lo e/ou compreendê-lo melhor. Com essa questão, buscou-se evidenciar também o que os respondentes consideram como componentes fundamentais na hora de identificar se uma cena é ou não natural.

Com as duas últimas questões do teste piloto (7 e 8), a finalidade era saber se para falantes nativos há diferenças entre representações feitas por atores e por pessoas "comuns", considerando as diferentes experiências e práticas. Como dissemos, perceber se essa diferença, de fato, se manifesta nas representações é útil, pois a teoria nos indica que qualquer pessoa poderia representar de modo natural, baseando-se em conhecimentos individuais. Portanto, esperava-se, com as duas perguntas, não só averiguar essas ideias na prática, mas tentar compreender se a representação de não atores pode parecer tão natural quanto aquelas feitas de modo profissional, por pessoas acostumadas a agir com naturalidade na frente das câmeras.

\subsubsection{A avaliação do teste piloto}

O piloto do teste de percepção foi respondido por três falantes nativos de italiano que vivem no Brasil. A decisão de pedir a colaboração desse público nos permitiu checar não só sua funcionalidade, mas também - e principalmente - obter um feedback dos participantes a respeito de questões específicas sobre o questionário, como sua extensão ou a clareza das perguntas. Todos, além de falantes nativos, trabalham como professores de italiano e/ou fazem pesquisa em Linguística.

Um dos problemas identificados nos resultados estava justamente relacionado à forma como o questionário havia sido organizado. Além disso, os participantes relataram falta de 
clareza nas questões sobre representação, o que nos ajudou na reelaboração. As respostas evidenciaram também dúvidas relativas às questões 2 e 4, com a alegação de que elas possuíam motivações parecidas. De fato, ambas as perguntas buscavam obter informações sobre o nível de naturalidade das ações e sobre o modo como elas foram dispostas confundiu os informantes. Questões dessa ordem e ainda outras mudanças foram feitas no teste final e serão descritas mais adiante.

Considerando os resultados do teste piloto, principalmente os comentários registrados pelos avaliadores nas questões abertas e seu feedback sobre o questionário como um todo, identificaram-se também caminhos para a análise dos dados.

Vejamos, por exemplo, as respostas à questão 6, na qual se pede para citar os elementos que guiaram os participantes na atribuição da pontuação. Percebe-se, a partir delas, qual foi, por parte dos informantes, a compreensão do escopo geral do teste:

(1) Per attribuire il punteggio ho pensato alla situazione reale e a quanto fosse possibile nella realtà. [Para atribuir a pontuação pensei na situação real e no quanto ela seria possível na realidade.]

ou ainda:

(2) (...) la mia valutazione dipende anche dal fatto che alcune di queste richieste personalmente non le farei o non le ho mai fatte. [(...) a minha avaliação depende do fato de que alguns desses pedidos eu, pessoalmente, não faria ou nunca fiz.]

Tais comentários nos deram indícios em relação à importância da experiência prévia e das inferências tanto na realização quanto na avaliação de interações da vida cotidiana (ANDORNO 2005; CAFFI, 2009; GOFFMAN, 1975 [1959]; VALLAURI, 2009), o que é significativo levar em conta no momento da observação dos dados.

Outras observações gerais propiciaram reflexões sobre o tipo de situação contida nos RPs avaliados:

(3) Allora... sicuramente non trovo naturale che qualcuno, arrivando a casa di un'altra persona, per quanto forte possa essere la pioggia, chieda così di fare una doccia. Non mi è mai successo, né di farlo né di vederlo, né di sentirlo (anche se non soffro di sinusite) (tra l'altro, se ho sentito bene, nell'ultimo video il ragazzo dice che è la prima volta che 
incontra quella ragazza in quella casa, il che fa sembrare la richiesta totalmente assurda. [Então... certamente não acho natural que alguém, chegando à casa de outra pessoa, independente de quanto a chuva seja forte, peça para tomar um banho. Nunca me aconteceu, nem de vivenciar, nem de ver [essa situação], nem de ouvi-la (embora eu não tenha sinusite) (entre outras coisas, se ouvi corretamente, no último vídeo o garoto diz que é a primeira vez que ele encontra a garota naquela casa, o que faz o pedido parecer totalmente absurdo.]

Com esse comentário, no qual o avaliador descreve especificamente a sequência de ações do oitavo vídeo, percebe-se que, embora a situação mostrada no RP tenha sido compreendida, o fato de ela não fazer parte da experiência do falante pode influenciar sua avaliação, levando-o a julgar o vídeo como pouco verossímil ou pouco natural.

Passemos agora à observação da pontuação atribuída às perguntas do teste piloto, para as quais, repetimos, foi utilizada uma escala Likert com a possibilidade de atribuir uma pontuação de 1 a 5 (Tabela 1). 
Tabela 1- Resultados do teste piloto

Informantes teste piloto

\begin{tabular}{|c|c|c|c|c|c|c|c|c|c|}
\hline & informantes & $\begin{array}{c}\text { vídeo } \\
1\end{array}$ & $\begin{array}{l}\text { vídeo } \\
2\end{array}$ & $\begin{array}{c}\text { vídeo } \\
3\end{array}$ & $\begin{array}{l}\text { vídeo } \\
4\end{array}$ & $\begin{array}{l}\text { vídeo } \\
5\end{array}$ & $\begin{array}{l}\text { vídeo } \\
6\end{array}$ & $\begin{array}{l}\text { vídeo } \\
7\end{array}$ & $\begin{array}{l}\text { vídeo } \\
8\end{array}$ \\
\hline & & \multicolumn{2}{|c|}{ água } & \multicolumn{2}{|c|}{ celular } & \multicolumn{2}{|c|}{ caneta } & \multicolumn{2}{|c|}{ chuva } \\
\hline \multirow{3}{*}{$\begin{array}{l}\text { Pergunta } 1 \\
\text { SITUAÇÃO }\end{array}$} & 1 & 5 & 4 & 4 & 5 & 5 & 4 & 1 & 1 \\
\hline & 2 & 5 & 5 & 5 & 4 & 5 & 3 & 3 & 3 \\
\hline & 3 & 5 & 5 & 5 & 2 & 4 & 5 & 3 & 4 \\
\hline \multirow{3}{*}{$\begin{array}{l}\text { Pergunta } 2 \\
\text { MODO }\end{array}$} & 1 & 5 & 5 & 1 & 4 & 5 & 4 & 3 & 4 \\
\hline & 2 & 4 & 5 & 4 & 4 & 5 & 5 & 5 & 4 \\
\hline & 3 & 5 & 5 & 5 & 4 & 5 & 5 & 4 & 5 \\
\hline \multirow{3}{*}{$\begin{array}{l}\text { Pergunta } 3 \\
\text { FALA }\end{array}$} & 1 & 5 & 5 & 1 & 2 & 5 & 2 & 5 & 4 \\
\hline & 2 & 4 & 5 & 5 & 5 & 5 & 5 & 5 & 5 \\
\hline & 3 & 5 & 5 & 5 & 5 & 5 & 5 & 3 & 5 \\
\hline \multirow{3}{*}{$\begin{array}{l}\text { Pergunta } 4 \\
\text { NATURALIDADE }\end{array}$} & 1 & 5 & 4 & 2 & 3 & 5 & 2 & 2 & 2 \\
\hline & 2 & 4 & 5 & 4 & 4 & 5 & 4 & 5 & 4 \\
\hline & 3 & 4 & 5 & 5 & 5 & 4 & 5 & 3 & 5 \\
\hline \multirow{3}{*}{$\begin{array}{l}\text { Pergunta } 5 \\
\text { IMPROVISAÇÃO/ } \\
\text { CÂMERAS }\end{array}$} & 1 & 5 & 4 & 2 & 3 & 4 & 2 & 5 & 3 \\
\hline & 2 & 3 & 5 & 4 & 4 & 5 & 5 & 5 & 4 \\
\hline & 3 & 4 & 5 & 5 & 5 & 5 & 5 & 3 & 5 \\
\hline
\end{tabular}

Ao observarmos as respostas da parte quantitativa, dois aspectos nos pareceram especialmente relevantes. O primeiro é a similaridade na avaliação dos vídeos 1, feito por "não atores", e 2, feito por atores, que todos os informantes consideraram muito verossímeis e 
naturais (atribuindo pontuação 4 e 5). Apenas na questão 5, o vídeo 1 recebeu a pontuação 3 . Se retomarmos as considerações dos informantes, obtidas a partir das perguntas abertas, podemos identificar que a verossimilhança, considerada para todos os aspectos dos dois vídeos, pode estar diretamente relacionada à situação com a qual o vídeo foi elaborado, ou seja, ao fato de todos já terem vivido ou visto algo parecido. Isso se confirma, por exemplo, quando contrapomos a situação da "água" às considerações sobre os vídeos 7 e 8 , nos quais a situação era pedir para tomar um banho por causa da chuva, que, segundo um dos informantes, era uma situação nunca vista ou vivida antes. Ao observarmos a pontuação dada apenas para o item "situação" de todos os vídeos, vemos que os primeiros receberam, em sua maioria, a avaliação 5 e apenas uma avaliação 4 , enquanto os outros não só variaram mais, mas obtiveram valores mais baixos.

O segundo aspecto que nos chama atenção observando os dados é que todos os avaliadores deram o maior valor da escala Likert (5) para o "modo" como o participante do vídeo faz o pedido (questão 2 do teste de percepção) e para a escolha de palavras e expressões ("fala", questão 3). Dois vídeos receberam a mesma pontuação nessas duas perguntas: o RP 2, no qual a ação é pedir um copo d'água na casa de um amigo, e o RP 5, que propõe como ação pedir uma caneta emprestada para um desconhecido na rua. Sabendo que, enquanto o vídeo 2 é uma gravação feita por atores e o vídeo 5 por "não atores", essa semelhança na avaliação do teste piloto parece já ser uma primeira confirmação de que não há diferenças significativas entre atores e "não atores" e, portanto, indício da capacidade inata do ser humano de representar situações comuns de modo natural (BOAL, 2015; GOFFMAN, 1975 [1959]).

Ainda que o teste piloto tenha contado com um número reduzido de participantes, as respostas contribuíram para a identificação tanto dos acertos, quanto das mudanças necessárias para a versão final do instrumento de coleta da presente pesquisa.

\subsection{Os instrumentos para a coleta de dados}

Após a análise dos resultados do teste piloto, os instrumentos foram reelaborados para que se chegasse à sua versão final. A reformulação serviu tanto para os questionários (judgment tests), utilizados para coletar os dados de falantes de italiano atores e "não atores", quanto para as entrevistas retrospectivas, realizadas com os participantes dos RPs “não atores". Ambos os instrumentos serão descritos a seguir. 


\subsubsection{Os questionários de avaliação dos role plays}

A primeira e principal mudança implementada nos questionários com base na avaliação do teste piloto diz respeito à ordem das questões. Sem desconsiderar a importância central da pergunta sobre a situação representada, que iniciava o teste piloto, para a versão definitiva decidiu-se que o questionário iniciaria com a pergunta sobre a espontaneidade das ações. Essa decisão foi tomada a fim de partir de uma avaliação mais geral do vídeo por parte do informante, que só depois é guiado para uma avaliação pontual dos elementos da representação considerados na pesquisa até que se chegue à avaliação da língua "captada" pelo RP.

Anteriormente, cada questão buscava observar se elementos que geralmente compõem uma representação se mostravam próximos do que o informante conhece como real, ou seja, se o modo como o participante agia e falava, bem como a situação representada por ele poderiam ser considerados verossímeis. No teste final, esses elementos passam a ser observados de acordo com dois critérios mais claramente definidos, a saber: naturalidade e adequação. Escolheu-se analisar cada elemento a partir de tais critérios, principalmente, tendo em vista tanto as opiniões de linguistas que apontam para a necessidade de se estudar a língua com dados naturalísticos ou que correspondam ao máximo à realidade (BAZZANELLA, 2008), quanto o que sustentam aqueles que indicam o uso do RP como instrumento útil na coleta de dados que se aproximam do real (FÉLIX-BRASDEFER 2007; BATALLER \& SHIVELY 2011). Visto que, como dissemos, por "natural" podemos entender tudo o que não se coloca como "produção artificial" ou ainda as representações que se apresentam "como se fossem produções da natureza" (PAVIS, p. 260), naturalidade é, para esta pesquisa, a proximidade entre as imagens obtidas por meio de RPs e aquilo que os avaliadores reconhecem como parte de sua realidade. Na vida real, para que uma ação seja aceita como natural, ela deve estar de acordo com normas impostas por contextos sociais específicos e com as chamadas "condições de felicidade" (AUSTIN, 1962), sendo inviável, por exemplo, a ação de batizar um navio, se realizada por um sujeito comum e em um ambiente não apropriado. Por esse motivo e sabendo que nos RPs esse contexto social é representado pelo setting, identificou-se a necessidade de investigar também se cada elemento considerado no teste se mostra adequado à situação proposta, uma vez que tal adequação parece ser não só um indicador de naturalidade ou "credibilidade", mas também um parâmetro utilizado pelos indivíduos para saber como agir em uma determinada situação (HYMES, 1964). Desse modo, o informante do questionário final deve definir e atribuir uma pontuação ao nível de naturalidade e ao nível de adequação de cada parte da "representação", que, como vimos, pode ser dividida entre ação e língua. 
$\mathrm{Na}$ fase de reelaboração foi percebida, também, a necessidade de voltar a observar o que a literatura de referência destaca como elementos essenciais para a construção das representações: (i) o ambiente ou cenário; (ii) a situação; (iii) a relação com o interlocutor. Os três elementos compõem o que Goffman (1975 [1959]) chama de "fachada", ou melhor, a parte da fachada que pode não depender diretamente do interlocutor, mas se estabelece na interação entre esses elementos, pois, é por meio deles que o indivíduo constrói as imagens de si que deseja representar para os outros. Desse modo, existiria uma conexão não só entre indivíduo e interlocutor, mas também entre esse "ator" (na vida, o indivíduo "comum") e a situação e o ambiente em que a encenação ocorre. É, então, a partir da representação realizada pelo indivíduo (por meio de ações e da língua) e também da interação entre as representações do indivíduo, o "cenário" e a situação, que o teste foi reorganizado, chegando-se à sua versão definitiva. Por isso, nessa versão foram inseridas as perguntas sobre a naturalidade do cenário físico e de sua adequação à situação do vídeo.

Como na versão anterior, o questionário se mantém dividido em dois blocos, o primeiro constituído principalmente por uma avaliação quantitativa, e o segundo, essencialmente qualitativo assim como vemos no Quadro 6:

Quadro 6 - comparação entre questionário piloto e questionário final

Teste de percepção piloto

\begin{tabular}{|c|c|}
\hline Teste de percepção piloto & Teste de percepção final \\
\hline $\begin{array}{l}\text { 1- Osserva con attenzione la situazione } \\
\text { presente nel video. Quanto ti sembra vicina } \\
\text { a situazioni che hai già visto/vissuto nella } \\
\text { vita reale? } \\
\text { [Observe com atenção a situação presente no } \\
\text { vídeo. Em que medida ela parece próxima de } \\
\text { situações que você já viu/viveu na vida real?] }\end{array}$ & $\begin{array}{l}1 \text { - Considerando che i partecipanti sapevano } \\
\text { di essere registrati, in che misura ti sembra } \\
\text { spontaneo lo svolgimento delle azioni in } \\
\text { questa situazione? } \\
\text { [Considerando que os participantes sabiam que } \\
\text { estavam sendo filmados, em que medida te } \\
\text { parece espontânea a realização das ações nessa } \\
\text { situação?] }\end{array}$ \\
\hline & $\begin{array}{l}2 \text { - Osserva con attenzione la situazione } \\
\text { presente nel video. Quanto ti sembra vicina a }\end{array}$ \\
\hline
\end{tabular}




\begin{tabular}{|c|c|}
\hline & $\begin{array}{l}\text { situazioni che hai già visto/vissuto nella vita } \\
\text { reale? } \\
\text { [Observe com atenção a situação presente no } \\
\text { vídeo. Em que medida ela parece próxima de } \\
\text { situações que você já viu/viveu na vida real?] }\end{array}$ \\
\hline $\begin{array}{l}\text { 3- Prova a rivolgere l'attenzione a quello } \\
\text { che viene detto, ovvero, alle parole e alle } \\
\text { espressioni scelte dal parlante per ottenere } \\
\text { quello di cui ha bisogno. In che misura ti } \\
\text { sembrano adatte alla situazione? } \\
\text { [Tente voltar sua atenção ao que é dito, ou } \\
\text { seja, às palavras e expressões escolhidas pelo } \\
\text { falante para obter o que precisa. Em que } \\
\text { medida a escolha lhe parece adequada à } \\
\text { situação?] }\end{array}$ & $\begin{array}{l}\text { 3 - Osserva adesso lo spazio in cui avviene la } \\
\text { situazione. Secondo te in che misura questo } \\
\text { spazio è naturale o vicino a spazi reali in cui } \\
\text { questa situazione potrebbe avvenire? } \\
\text { [Observe agora o espaço no qual a situação } \\
\text { acontece. Segundo você, em que medida esse } \\
\text { espaço é natural ou próximo de espaços reais } \\
\text { nos quais essa situação poderia ocorrer?] }\end{array}$ \\
\hline \multirow[t]{2}{*}{$\begin{array}{l}\text { 2- Osserva ora il modo in cui il parlante fa } \\
\text { la richiesta, ossia, come si muove, che } \\
\text { atteggiamenti assume, che tono della voce } \\
\text { ha ecc. Quanto ti sembra vicino a quello che } \\
\text { hai già visto/vissuto nella vita reale? } \\
\qquad \text { [Observe o modo em que o falante faz } \\
\text { o pedido, ou seja, como se move, que atitudes } \\
\text { manifesta, qual tom de voz expressa, etc. } \\
\text { Quanto se aproxima de algo que você já } \\
\text { viu/viveu na vida real?] }\end{array}$} & $\begin{array}{l}4 \text { - In che misura lo spazio mostrato nel vídeo } \\
\text { ti sembra adeguato a questa situazione? } \\
\text { [Em que medida o espaço mostrado no } \\
\text { vídeo te parece adequado à situação?] }\end{array}$ \\
\hline & $\begin{array}{l}5 \text { - Osserva il modo in cui il parlante fa la } \\
\text { richiesta, ossia, come si muove, che } \\
\text { atteggiamenti assume, che tono della voce ha } \\
\text { ecc. Quanto naturali o vicine a quello che hai } \\
\text { già visto o vissuto nella realtà ti sembrano le } \\
\text { azioni di questo video? } \\
\text { [Observe o modo como o falante faz o pedido, } \\
\text { ou seja, como se move, que atitudes manifesta, } \\
\text { qual tom de voz expressa etc. Quão naturais ou } \\
\text { próximas do que você já viu ou viveu na vida } \\
\text { real te parecem as ações desse vídeo?] }\end{array}$ \\
\hline
\end{tabular}


3- Prova a rivolgere l'attenzione a quello che viene detto, ovvero, alle parole e alle espressioni scelte dal parlante per ottenere quello di cui ha bisogno. In che misura ti sembrano adatte alla situazione?
6 - In che misura le azioni svolte dai partecipanti nei video ti sembrano adatte alla situazione?

[Em que medida as ações desenvolvidas pelos participantes no vídeo te parecem adequadas à situação?]

7 - Prova ora a rivolgere l'attenzione a quello che viene detto, ovvero, alle parole $e$ alle espressioni scelte dai parlanti nell'interazione. Quanto naturali ti sembrano le loro scelte?

[Tente agora voltar sua atenção para o que é dito, ou seja, para as palavras e expressões escolhidas pelo falante para conseguir aquilo que ele precisava. Quão naturais te parecem essas escolhas?]

8 - In che misura quello che viene detto dai partecipanti ti sembra adatto alla situazione?

[Em que medida o que é dito pelo participante te parece adequado à situação?]
6 - Riesci a dire quali elementi ti hanno guidato al momento di attribuire il tuo punteggio? Hai ancora altre osservazioni da aggiungere sulla "naturalezza" dei video che hai visto?

[Você consegue dizer quais elementos te guiaram no momento de atribuir a pontuação? Tem ainda alguma observação que gostaria de acrescentar sobre a "naturalidade" dos vídeos que assistiu?]
9 - Riesci a dire quali elementi ti hanno guidato al momento di attribuire il tuo punteggio? Hai ancora altre osservazioni da aggiungere sulla "naturalezza" dei video che hai visto?

[Você consegue dizer quais elementos te guiaram no momento de atribuir a pontuação? Tem ainda alguma observação que gostaria de acrescentar sobre a "naturalidade" dos vídeos a que assistiu?] 


\begin{tabular}{|c|c|}
\hline $\begin{array}{l}7 \text { - Alcuni dei video che hai visto sono stati } \\
\text { registrati da attori professionisti. Riusciresti } \\
\text { a dire quali? }\end{array}$ & $\begin{array}{l}10 \text { - Alcuni dei video che hai visto sono stati } \\
\text { registrati da attori professionisti. Riusciresti a } \\
\text { dire quali? } \\
\text { [Alguns dos vídeos aos quais você assistiu } \\
\text { foram gravados por atores profissionais. Você } \\
\text { saberia dizer quais?] }\end{array}$ \\
\hline $\begin{array}{l}8 \text { - Quali aspetti ti hanno fatto decidere quali } \\
\text { sono } i \text { video registrati da attori professioni e } \\
\text { quali da "persone comuni"? }\end{array}$ & $\begin{array}{l}11 \text { - Quali aspetti ti hanno fatto decidere quali } \\
\text { sono } \text { i video registrati da attori professioni e } \\
\text { quali da "persone comuni"? } \\
\text { [Quais aspectos te levaram a decidir quais são } \\
\text { os vídeos gravados por atores profissionais e } \\
\text { quais por "pessoas comuns"?] }\end{array}$ \\
\hline
\end{tabular}

Após as alterações, o questionário final ${ }^{27}$ foi enviado aos informantes com a seguinte configuração:

${ }^{27}$ O questionário final pode ser acessado a partir do seguinte link: https://forms.gle/1mQPMmT8ai5dvmXX7 
Figura 2-Questionário final

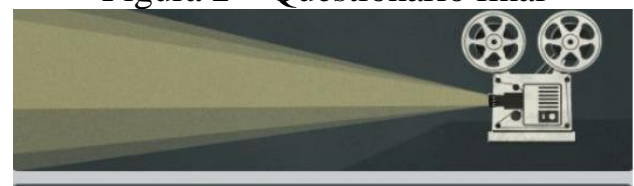

Uno sguardo sullitaliano quotidiano

*obrigatório

\section{Come fanno le richieste gli italiani?}

Video 1

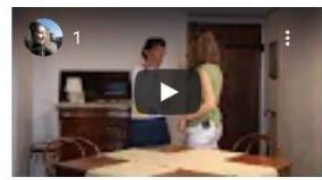

1- Considerando che i partecipanti sapevano di essere registrati, in che misura ti sembra spontaneo lo svolgimento delle azioni in questa situazione? (1) .

$\begin{array}{lllll}1 & 2 & 3 & 4 & 5 \\ 0 & 0 & 0 & 0 & 0\end{array}$

2 - Osserva con attenzione la situazione presente nel video. Quanto ti sembra vicina a situazioni che hai già visto/vissuto nella vita reale? (1) .

$\begin{array}{lllll}0^{2} & 0^{4} & 0 & 0 & 0\end{array}$

3 - Osserva adesso lo spazio in cui avviene la situazione, secondo te in che misura questo spazio è naturale o vicino a spazi reali in cui questa situazion potrebbe avvenire? "

000000

4 - In che misura lo spazio mostrato nel video ti sembra adeguato a questa ituazione?

$\begin{array}{lllll}1 & 2 & 3 & 4 & 5 \\ 0 & 0 & 0 & 0 & 0\end{array}$

5 - Osserva il modo in cuili parlante fa la richiesta. ossia, come si muove, che atteggiamenti assume, che tono della voce ha ecc. Quanto naturalio vicine a

$\begin{array}{lllll}1 & 2 & 3 & 4 & 5 \\ 0 & 0 & 0 & 0 & 0\end{array}$
6 - In che misura le azioni svolte dai partecipanti nei video ti sembrano adatte alla

$\begin{array}{lllll}1 & 2 & 3 & 4 & 5 \\ 0 & 0 & 0 & 0 & 0\end{array}$

7 - Prova ora a rivolgere l'attenzione a quello che viene detto, ovvero. alle parole e alle espressioni scelte dai parlanti nellinterazione. Quanto naturali ti sembrano le loro scelte?

00000

8 - In che misura quello che viene detto dai partecipanti ti sembra adatto alla situazione?*

$\begin{array}{llll}0^{3} & 0^{4} & 0 & 0\end{array}$




\subsubsection{Entrevistas retrospectivas}

Como já explicado, o roteiro das entrevistas retrospectivas segue a mesma ordem do questionário de percepção, mas é composto somente por perguntas abertas. Embora tais perguntas partam também das mesmas referências teóricas, esse instrumento busca guiar o olhar do informante para a avaliação de suas próprias ações e tem o seguinte formato (Quadro 7).

Quadro 7 - roteiro para entrevistas retrospectivas

1 - Considerando che sapevi delle registrazioni, quanto spontaneo è stato per te lo svolgimento delle azioni proposte? Qual' è stata la cosa più facile da fare? E quella più difficile? Perché?

[Considerando que você sabia das gravações, o quão espontânea foi para você a realização das ações propostas? Qual foi a coisa mais fácil de fazer? E a mais difícil? Por quê?]

2 - Osserva con attenzione la situazione presente nel video. Avevi già visto o vissuto una situazione simile a quella a cui hai dovuto partecipare? Cosa ti ricordi di quello che ti è stato proposto di fare?

[Observe atentamente a situação do vídeo. Você já viu ou vivenciou uma situação semelhante à que teve que participar? O que você lembra sobre o que lhe propuseram fazer?]

3 - Osserva adesso lo spazio in cui è avvenuta la situazione, secondo te quanto naturale o vicino a spazi reali in cui questa situazione potrebbe avvenire è lo spazio dove hai fatto il video?

[Agora, observe o espaço onde se deu a situação, na sua opinião quão natural ou próximo dos espaços reais em que essa situação poderia ocorrer é o espaço onde você fez o vídeo?]

4 -In che misura questo spazio ti sembra adeguato alla situazione che ti è stata proposta? Questo spazio ti ha aiutato a svolgere le azioni?

[Em que medida este espaço parece adequado à situação que te foi proposta? Esse espaço ajudou você a realizar as ações?]

5 - Osserva ora il modo in cui hai fatto la richiesta, ossia, come ti muove, che atteggiamenti hai assunto, che tono della voce avevi ecc. Questi aspetti ti sembrano naturali o vicini a come agisci nella vita reale? C'è qualcosa che hai fatto nel video che non faresti o che faresti in modo diverso se fosse una situazione reale? Cosa? Riesci a spiegare come lo faresti?

[Agora observe a forma como você fez o pedido, ou seja, como você se move, quais atitudes assumiu, que tom de voz utilizou etc. Esses aspectos parecem naturais para você ou próximos de como você age na vida real? Há alguma coisa que você fez no vídeo que não 
faria ou que faria de forma diferente se fosse uma situação real? O quê? Você pode explicar como você faria isso?]

6 - Quanto adatte alla situazione proposta ti sembrano le azioni svolte da te nel video? Perché?

[Quão adequadas à situação proposta te parecem as ações realizadas por você no vídeo? Por quê?]

7 - Prova a rivolgere l'attenzione a quello che viene detto, ovvero, alle parole ed espressioni che hai scelto per ottenere quello di cui avevi bisogno. Quanto naturali ti sembrano queste scelte?

[Tente prestar atenção ao que está sendo dito, ou seja, às palavras e expressões que você escolheu para conseguir o que precisava. Quão naturais essas escolhas te parecem ser?]

8 - Questi elementi ti sembrano adatti alla situazione? In che misura sono parole ed espressioni che usi nella vita quotidiana? C'è qualcosa che hai detto nel video che non diresti se questa fosse una situazione reale?

[Esses elementos te parecem adequados à situação? Em que medida são palavras e expressões que você usa no dia a dia? Há algo que você disse no vídeo que não diria se essa fosse uma situação real?]

9 - Hai altre osservazioni da aggiungere sulla "naturalezza" delle azioni da te svolte nel video?

[Você tem outras observações a acrescentar sobre a "naturalidade" das ações que realizou no vídeo?]

Desenvolvido para ser realizado por meio da plataforma Skype, o processo de coleta de dados a partir das entrevistas diverge dos questionários, na medida em que aqui cada informante assiste apenas aos vídeos que gravou, respondendo às perguntas oralmente logo em seguida. Após a realização das entrevistas, os áudios foram transcritos para poderem ser melhor estudados. Outro ponto fundamental desse instrumento é o contato direto com o informante e a possibilidade de esclarecer qualquer dúvida que possa surgir no decorrer da coleta de dados (SCHNEIDER, 2018) tanto por parte do pesquisador, quanto por parte do entrevistado. Uma alteração feita especificamente nos roteiros foi a inserção de uma parte específica na questão 4, que busca saber se o espaço em que o vídeo foi gravado colaborou para o desenvolvimento das ações. A intenção com essa parte da pergunta era obter informações específicas sobre a relação direta entre "ator" (sempre entendido aqui como "pessoa comum") e cenário, prevista por Goffman (1975 [1959]). 


\subsection{Os participantes da pesquisa: atores e "não atores" como julgadores}

Como dissemos, os avaliadores do judgement test são falantes nativos de italiano divididos em dois grupos: (i) "não atores", ou seja, pessoas que não têm um contato cotidiano com a prática profissional de encenação e filmagem; (ii) atores, isto é, pessoas que trabalham com teatro ou cinema. $\mathrm{Na}$ imagem a seguir, foram resumidas as principais características do grupo de avaliadores "não atores” (Figura 3).

Figura 3 - Dados dos avaliadores "não atores"

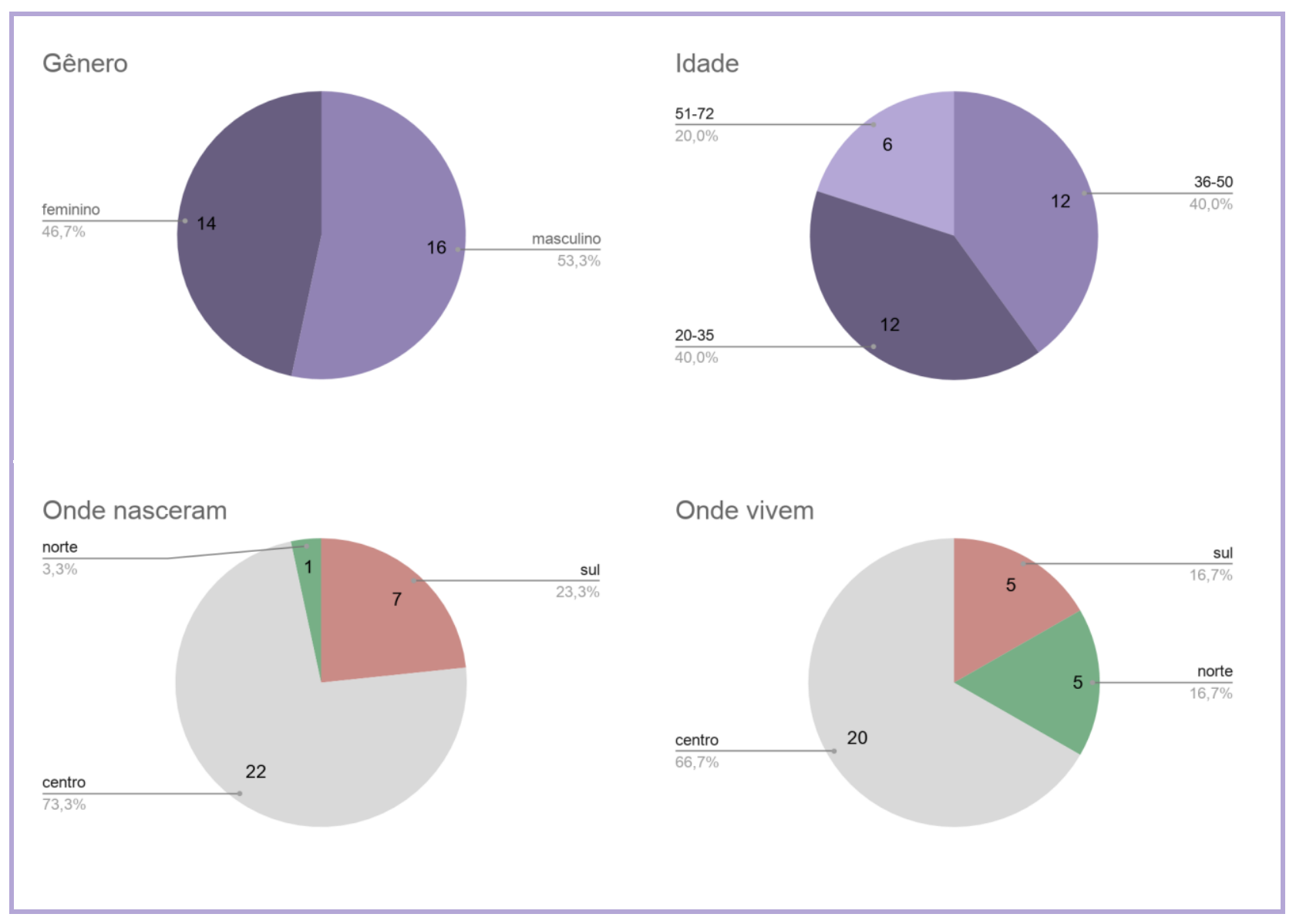

Como se vê, o grupo dos "não atores" é composto por 16 avaliadores do gênero masculino e 14 do gênero feminino. Doze informantes têm idade entre 20 e 35 anos e o mesmo número entre 36 e 50 anos, enquanto apenas 6 têm entre 51 e 72 anos. A maioria nasceu na Itália central (entre as cidades mencionadas há Roma, no Lazio, e Macerata, na região Marche). Uma parte dos informantes (7) nasceu no sul da Itália, em cidades como Bari e Altamura (Puglia) e um informante nasceu em Florença (Toscana). No que diz respeito ao local no qual esses informantes atualmente residem, a maior parte (20 informantes) citou cidades em regiões centrais da Itália, 5, cidades do sul (Puglia) e 5, do norte (Toscana). 
A seguir (Figura 4), temos os dados do grupo de informantes atores:

Figura 4- Dados dos avaliadores atores

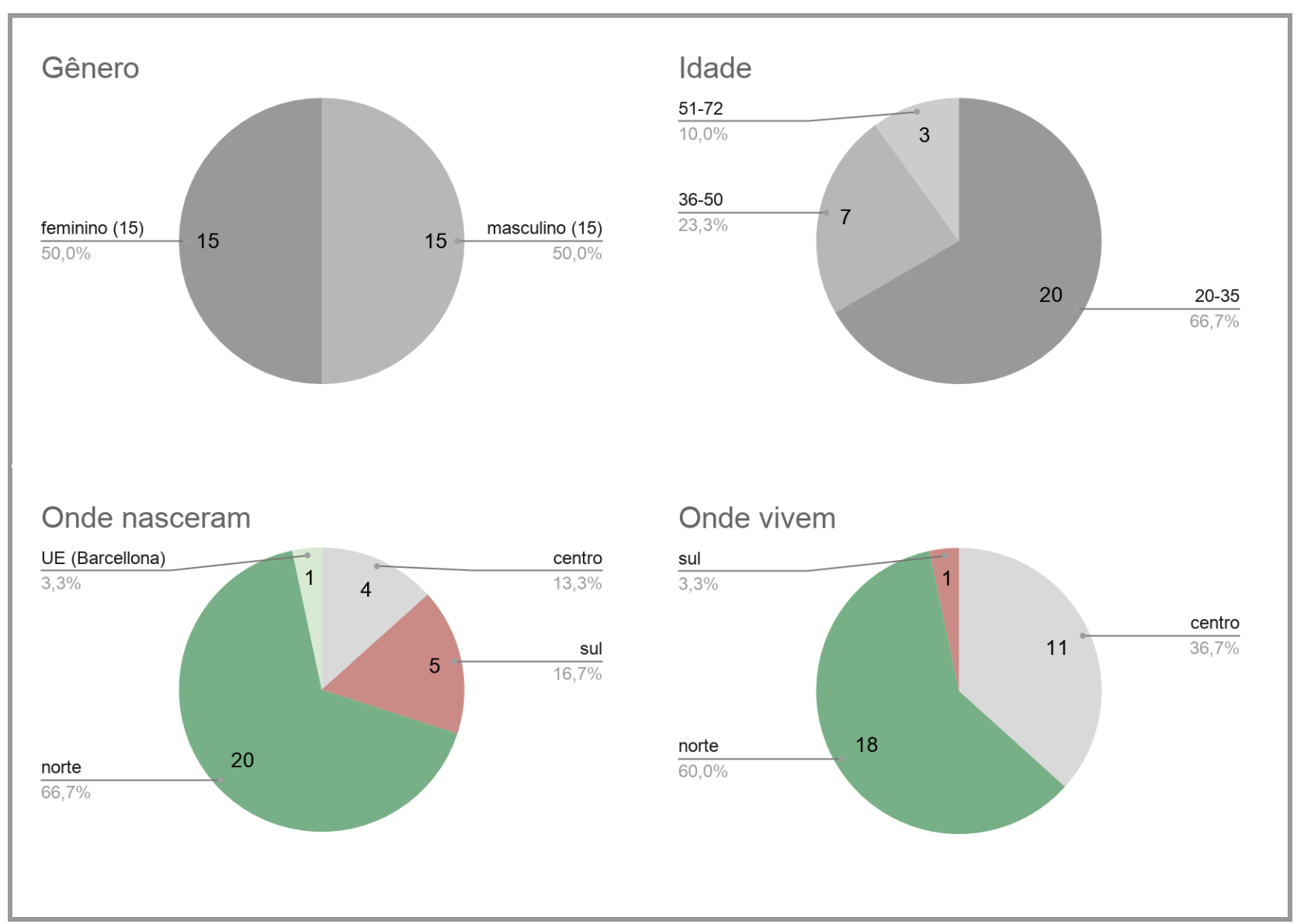

O grupo dos atores é composto por 15 avaliadores do gênero masculino e 15 do gênero feminino. A maioria (20) está na faixa etária entre 20 e 35 anos, 7, entre 36 e 50 anos e 3, entre 51 e 71 anos. Todos os indivíduos que responderam ao questionário são falantes nativos de italiano, embora um deles tenha nascido na Espanha. A maioria dos respondentes (20) nasceu no norte da Itália, em cidades como Veneza (Veneto) e Milão (Lombardia). Uma parte dos informantes (4) nasceu na região central da Itália, em cidades como Roma (Lázio) e Perugia (Umbria), e 5 informantes nasceram no sul do país, em cidades como Bari (Puglia) Messina (Calábria) e Nápoles (Campania). A maior parte (18 informantes) reside no norte do país, em regiões como Veneto e Lombardia, 5 informantes, na região central (Lázio) e apenas 1, no sul, especificamente em Nápoles (Campania). 


\subsection{Metodologia de análise: tratamento estatístico e análise qualitativa}

Tendo em vista que se trata de um estudo experimental, para a análise dos dados foi pensada uma combinação de testes estatísticos que parte, em primeiro lugar, da verificação da eficácia do instrumento elaborado para a coleta de dados. Essa análise é realizada a partir do teste Alfa de Cronbach que, no nosso caso, verifica a importância da inter-relação entre as perguntas que compõem o questionário. O segundo teste utilizado tinha o objetivo de verificar o Interrater Agreement, utilizado para verificar os níveis de concordância entre os dois grupos de avaliadores, e foi calculado com o coeficiente de correlação intraclasse, para saber se e em que medida as avaliações dos dois grupos ("não atores" e atores) convergiam em relação à percepção da naturalidade e da adequação dos vídeos. Por fim, o teste aplicado a todas as pontuações atribuídas pelos 60 avaliadores (30 atores e 30 "não atores") é o General Linear Model (GLM), no qual está incluído também o teste MANOVA (Multiple ANOVA), mais robusto quando há duas ou mais variáveis dependentes e independentes ${ }^{28}$. Foram manipulados - e são, portanto, variáveis independentes - tanto os oito vídeos quanto os grupos de avaliadores. Para os vídeos, consideramos também o grau de imposição, já que quatro vídeos foram gravados usando situações de baixo grau de imposição ("água" e "caneta”) e quatro de alto grau de imposição ("temporal” e "celular"). Mais uma variável independente é que quatro vídeos foram gravados por "não atores" e quatro por atores.

Para verificar o efeito das variáveis, comparando, em especial, atores e "não atores", foram feitos também testes de significância com um valor $\alpha$ igual a $5 \%(\mathrm{p}<0,05)$. O objetivo desse teste é confirmar ou negar a hipótese "nula" ou inicial do estudo. Sendo que, neste trabalho, partimos do pressuposto de que não há uma separação entre realidade e encenação, a hipótese inicial era que atores e "não atores" não apenas encenariam RPs com níveis similares de naturalidade, mas também que os avaliariam de forma parecida. Deste modo, a constatação de uma diferença nas avaliações $(p<0,05)$ negaria a hipótese inicial, enquanto um $p$ superior a 0,05 confirmaria a hipótese de que há similaridade entre atores e "não atores".

Para as entrevistas retrospectivas, o primeiro passo foi a transcrição e, em seguida, a identificação dos elementos que respondiam às diferentes questões que foram feitas aos participantes. Como também essas entrevistas seguiram os mesmos parâmetros utilizados nos questionários, procuramos também separar seu conteúdo por parâmetro, de modo a facilitar a

\footnotetext{
${ }^{28}$ Todos os testes estatísticos foram realizados com o software IBM - SPSS (Statistical Package for Social Science - IBM Corp. V. 20, USA).
} 
comparação entre a percepção dos próprios participantes sobre sua "encenação" (avaliação êmica) e o julgamento dos informantes externos (avaliação ética). 


\section{O ponto de vista do falante: atores e não atores como avaliadores de role plays em italiano}

Neste capítulo, será apresentada a análise dos dados obtidos por meio dos questionários de percepção (avaliação quantitativa e perguntas abertas) e das entrevistas retrospectivas, realizadas só com os falantes nativos "não atores" que participaram da "encenação" e gravação dos RPs selecionados para a nossa pesquisa.

A primeira parte será dedicada aos testes estatísticos realizados para verificar a consistência interna e a validade do instrumento utilizado para a pesquisa. Em seguida, serão mostrados os resultados gerais da avaliação, considerando os dois grupos de avaliadores (30 "não atores" e 30 atores), as situações propostas e o efeito de interação entre grupos e situações, com base nos oito parâmetros escolhidos.

Após essas observações mais gerais, será apresentada uma análise mais detalhada para cada um dos parâmetros do teste, ilustrando de que maneira "não atores" e atores avaliam os diferentes aspectos das representações (GOFFMAN, 1975 [1959]; 1981]), que consideramos constitutivos dos RPs, bem como da representação em si. Nessa etapa, as avaliações dos falantes nativos, analisadas por meio de testes estatísticos, serão ainda combinadas às respostas das entrevistas retrospectivas, a fim de verificar se e em que medida a perspectiva ética, isto é, a perspectiva dos avaliadores externos ao processo de elaboração dos RPs, converge ou diverge da perspectiva êmica ou interna, que é representada pelo ponto de vista de quatro dos participantes, que gravaram os vídeos (KÁDÁR \& HAUGH, 2013).

Por fim, partindo de um dos principais pressupostos teóricos adotados neste trabalho, segundo o qual todo indivíduo é capaz de atuar (BOAL, 2015; GOFFMAN, 1975 [1959]), serão comparadas as encenações realizadas por "não atores" e atores, com o objetivo de observar se e em que medida há diferenças, sempre levando em consideração os mesmos parâmetros (espontaneidade, verossimilhança, espaço, ação e língua).

\subsection{A validação do instrumento de pesquisa}

No que diz respeito aos dados quantitativos, a amostra consiste nas pontuações atribuídas por 60 falantes nativos de italiano (30 "não atores" e 30 atores), que avaliaram oito vídeos, a partir das mesmas oito perguntas. A divisão entre avaliadores "não atores" e atores se justifica, pois, embora partamos do pressuposto de que todos os indivíduos possam julgar comportamentos e verificar sua adequação ao contexto (HYMES, 1964), atores seriam mais 
preparados para avaliar encenações, por terem como prática profissional a observação e reencenação consciente do cotidiano (BOAL, 2015; GOFFMAN, 1981). Além disso, mesmo considerando o conceito de falante nativo como uma abstração (v. nota 25), ele é, ainda assim, usado como indicador para comparação em muitas pesquisas que investigam usos da língua.

Como primeira etapa de análise, foi calculado o Alfa de Cronbach para verificar a consistência interna - ou confiabilidade - do instrumento e seu uso adequado. O resultado, obtido inserindo as oito perguntas propostas para a avaliação e as pontuações atribuídas pelos participantes-avaliadores, é 0,938 , muito superior ao 0,8 , que o valor mínimo considerado bom (Tabela 2).

Tabela 2 - Confiabilidade do instrumento de pesquisa - Alfa de Cronbach

Nr. de Itens

\begin{tabular}{lc}
\hline 0,938 & 8 \\
\hline
\end{tabular}

Ainda para avaliar o instrumento utilizado, foi medida a correlação entre os 8 itens do questionário, para verificar se havia a independência mínima necessária entre eles e, ao mesmo tempo, a necessária correlação, mais uma garantia da confiabilidade do instrumento.

Tabela 3- Correlação entre os itens do questionário

\begin{tabular}{lllll}
\hline & Média & Mínimo & Máximo & Nr. of Items \\
\hline Correlação entre os itens & & & & \\
&, 650 &, 476 &, 874 & 8 \\
\hline
\end{tabular}

O resultado do teste pode ser considerado bom, já que o valor médio não deve ser inferior a 0,4 e também não pode ser maior do que 0,9 . Desse modo, será garantido que haja a desejável correlação entre os itens, assegurando, contudo, que cada pergunta seja independente, no sentido de medir aspectos diferentes, mas coerentes com a escala proposta (uma correlação entre os itens muito elevada resulta na não necessidade de todos os itens).

Depois de aferir a confiabilidade do teste, foi calculado o coeficiente de correlação intraclasse, para verificar a chamada interrater reliability, que permite mensurar a confiabilidade das medidas utilizadas, por meio da média das pontuações atribuídas por todos 
os avaliadores. De fato, observando sua variabilidade (Tabela 4), é possível constatar a homogeneidade dos critérios escolhidos e estimar sua reprodutibilidade.

Tabela 4 - Coeficiente de correlação intraclasse (medidas médias)

\begin{tabular}{|c|c|c|}
\hline Atores & & Intervalo de confiança \\
\hline Não atores & $\mathbf{0 , 9 3 0}$ & $95 \%$ \\
\hline
\end{tabular}

A tabela mostra que o resultado é 0,930 , muito superior ao limite mínimo considerado bom que é 0,7. Assim, a combinação dos valores dos três cálculos realizados (Alfa de Cronbach, correlação entre os itens do questionário e coeficiente de correlação intraclasse) confirma que o questionário efetivamente mediu o que nos propomos a medir, fornecendo dados relativos à naturalidade e adequação dos RPs escolhidos. Na próxima seção, passaremos às análises gerais das avaliações dos dois grupos.

\section{2 "Não atores" vs. atores: a percepção geral dos dois grupos de avaliadores}

$\mathrm{Na}$ primeira etapa da análise quantitativa dos resultados, utilizamos o GLM multivariado $^{29}$ e comparamos para cada parâmetro da avaliação: (a) os dois grupos de avaliadores; (b) as situações (“água", "caneta", "celular" e "temporal”) entre elas; (c) o efeito de interação entre grupos e situações. Os principais resultados $\left(\mathrm{F}^{30}\right.$ e $\left.p\right)$ foram reportados na tabela a seguir (Tabela 5).

Tabela 5 - Resultados do General Linear Model (GLM): avaliadores e situações

\begin{tabular}{|l|c|c|c|}
\hline & & F & $\boldsymbol{p}$ \\
\hline \multirow{4}{*}{$\begin{array}{c}\text { Grupo avaliadores } \\
\text { ("não atores"/ atores) }\end{array}$} & espontaneidade & 9,811 &, 020 \\
\cline { 2 - 4 } & verossimilhança & 2,133 &, 145 \\
\cline { 2 - 4 } & espaço (naturalidade) & 2,188 &, 140 \\
\cline { 2 - 4 } & espaço (adequação) & 2,004 &, 157 \\
\hline
\end{tabular}

${ }^{29}$ Foi aplicada a correção Sidak para dados não normais (cf. FIELD, 2013).

${ }^{30} \mathrm{~F}$ corresponde à diferença entre os valores médios, obtida calculando a variação entre os grupos, dividida pela variação no interior de cada grupo. Quanto menor o resultado, menor a diferença e vice-versa. 


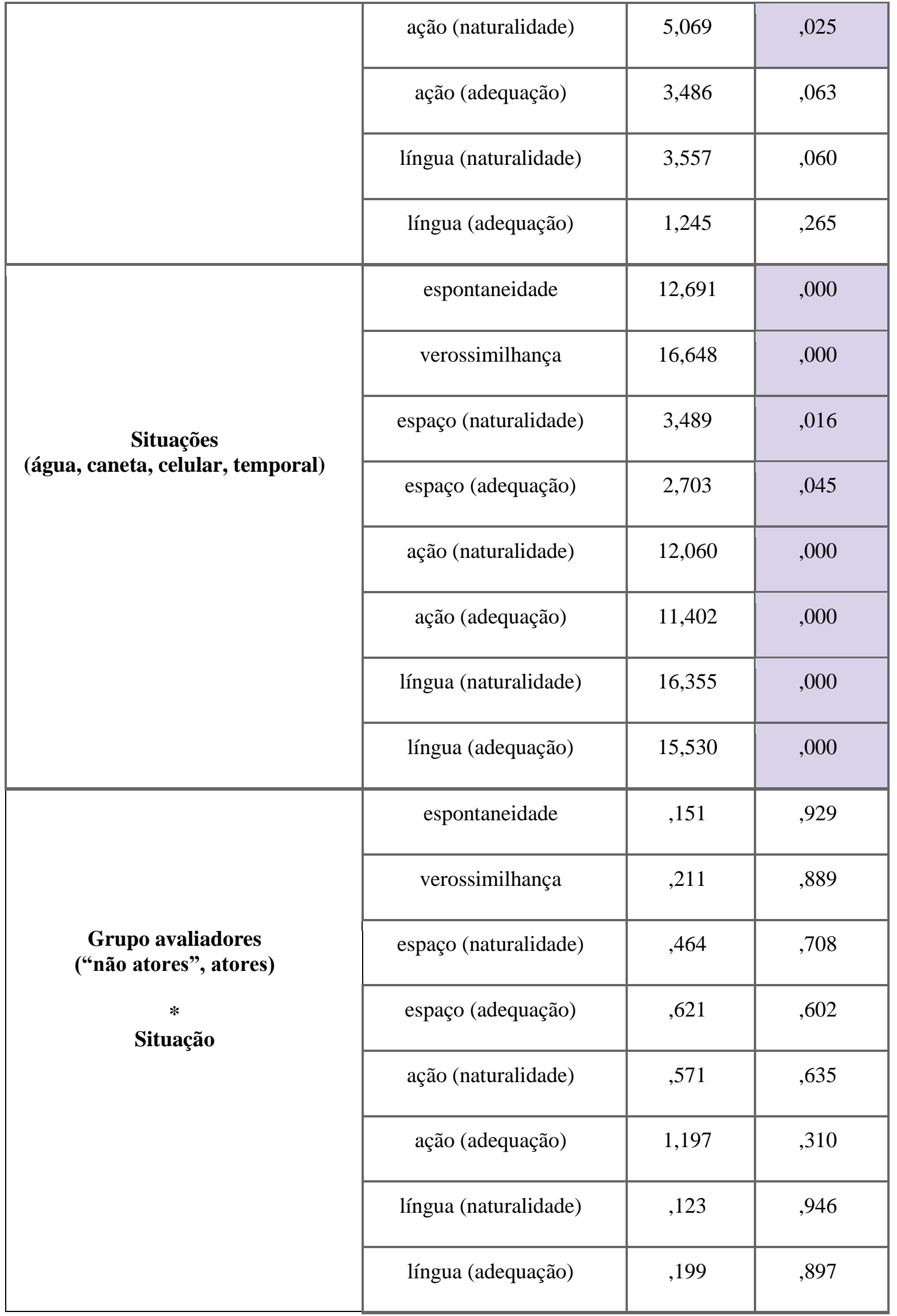


$\mathrm{Na}$ comparação entre os dois grupos de avaliadores, a análise mostrou diferença significante $(p<0,05)$ em apenas 2 parâmetros. A primeira diferença identificada está no parâmetro "espontaneidade" ( $\mathrm{F}=9,811 ; p=0,002)$ e a segunda, em "ação-naturalidade" ( $\mathrm{F}=$ $5,069 ; p=0,025)$. Essas diferenças serão discutidas mais adiante, nas seções dedicadas a cada um dos parâmetros. Nesse momento, cabe observar que uma primeira análise geral dos critérios verificados por meio do teste aponta mais semelhanças que diferenças entre as avaliações de "não atores" e atores, uma vez que, como se pode ver na primeira parte da tabela, os outros critérios não apresentaram diferenças estatisticamente significantes (todos os outros resultados de $p$ são > 0,05). Essa semelhança nas avaliações dos dois grupos pode ser considerada um primeiro indício de que a avaliação do cotidiano não depende apenas do olhar treinado dos atores. Por mais que os atores possam ter, em alguns casos, avaliações mais pormenorizadas e rigorosas, parece se confirmar a ideia de que todos os indivíduos são capazes de julgar o que é ou não adequado em determinada situação, já que é desse julgamento que depende uma comunicação eficaz (HYMES, 1964, 1972).

No que diz respeito à comparação entre as quatro situações (“água", "celular", "caneta" e "temporal"), as análises mostram que foi encontrada diferença estatisticamente significante para todas (valor mínimo de $\mathrm{F}=2,703$; todos os valores de $p<0,05$ ) e em todos os parâmetros, independente de se tratar de avaliadores "não atores" ou atores. Esses resultados indicam que a situação altera a avaliação muito mais do que o grupo ao qual os informantes pertencem e que depende das características de cada situação qual será a pontuação atribuída. Confirma-se assim que, em uma interação, o papel determinante é representado pela situação comunicativa e por todos os elementos que a constituem (GOFFMAN, 1975 [1959]; HYMES, 1974). De fato, na terceira parte da tabela, na qual se encontram os valores do efeito de interação entre grupos e situações, não há nenhuma diferença estatisticamente significante, o que evidencia, mais uma vez, que a avaliação dos dois grupos é muito semelhante em todas as situações.

Mesmo assim, ao observarmos de forma mais detalhada a média (M) e o desvio padrão ${ }^{31}$ (DP) das avaliações atribuídas por cada grupo, levando em conta tanto os critérios quanto as situações, percebemos que existem algumas diferenças que podem ser verificadas a seguir (Tabela 6).

\footnotetext{
${ }^{31} \mathrm{O}$ desvio padrão é o valor que indica a dispersão dos dados ou o quanto eles se distanciam da média. Sendo assim, quanto mais próximo do 0 for o valor do desvio padrão, mais homogênea e concentrada é a amostra.
} 
Tabela 6- Média e desvio padrão da avaliação dos vídeos por situação

\begin{tabular}{|c|c|c|c|c|c|c|c|c|c|}
\hline \multirow[t]{2}{*}{ Avaliadores } & \multirow[t]{2}{*}{ Vídeo/RP } & Média & DP & Média & DP & Média & DP & Média & DP \\
\hline & & \multicolumn{2}{|c|}{ Espontaneidade } & \multicolumn{2}{|c|}{$\begin{array}{c}\text { Ação } \\
\text { (naturalidade) }\end{array}$} & \multicolumn{2}{|c|}{$\begin{array}{c}\text { Ação } \\
\text { (naturalidade) }\end{array}$} & \multicolumn{2}{|c|}{$\begin{array}{c}\text { Língua } \\
\text { (naturalidade) }\end{array}$} \\
\hline \multirow[t]{4}{*}{ não atores } & água & 3,57 & 1,03 & 3,62 & 1,11 & 4,12 & 85 & 3,67 & 1,07 \\
\hline & celular & 3,20 & 1,13 & 3,07 & 1,25 & 3,90 & ,95 & 3,15 & 1,23 \\
\hline & caneta & 3,93 & 1,02 & 3,72 & 1,09 & 3,90 & 1,08 & 3,90 & 1,05 \\
\hline & temporal & 3,22 & 1,15 & 3,07 & 1,23 & 3,65 & 1,12 & 2,90 & 1,20 \\
\hline \multirow[t]{5}{*}{ atores } & água & 3,28 & 1,08 & 3,20 & 1,16 & 3,82 & 1,24 & 3,35 & 1,23 \\
\hline & celular & 2,87 & 1,36 & 2,78 & 1,39 & 3,92 & 1,05 & 3,02 & 1,35 \\
\hline & caneta & 3,67 & 1,19 & 3,70 & 1,11 & 3,80 & 1,16 & 3,72 & 1,18 \\
\hline & temporal & 2,77 & 1,32 & 2,78 & 1,35 & 3,43 & 1,36 & 2,70 & 1,33 \\
\hline & & \multicolumn{2}{|c|}{ Verossimilhança } & \multicolumn{2}{|c|}{$\begin{array}{c}\text { Ação } \\
\text { (adequação) }\end{array}$} & \multicolumn{2}{|c|}{$\begin{array}{c}\begin{array}{c}\text { Espaço } \\
\text { (adequação) }\end{array} \\
\end{array}$} & \multicolumn{2}{|c|}{$\begin{array}{c}\begin{array}{c}\text { Língua } \\
\text { (adequação) }\end{array} \\
\end{array}$} \\
\hline \multirow[t]{4}{*}{ não atores } & água & 3,73 & 1,07 & 3,82 & 85 & 4,08 & ,91 & 3,70 & 1,05 \\
\hline & celular & 3,23 & 1,13 & 3,25 & ,14 & 3,87 & ,95 & 3,28 & 1,12 \\
\hline & caneta & 3,57 & 1,28 & 3,52 & ,19 & 3,97 & 1,06 & 3,73 & 1,07 \\
\hline & temporal & 2,82 & 1,19 & 2,98 & 13 & 3,58 & 1,12 & 2,90 & 1,17 \\
\hline \multirow[t]{4}{*}{ atores } & água & 3,70 & 1,17 & 3,37 & ,02 & 3,80 & 1,20 & 3,50 & 1,11 \\
\hline & celular & 2,97 & 1,21 & 3,08 & ,37 & 3,90 & 1,04 & 3,15 & 1,20 \\
\hline & caneta & 3,43 & 1,31 & 3,62 & ,11 & 3,68 & 1,28 & 3,75 & 1,08 \\
\hline & temporal & 2,62 & 1,14 & 2,72 & ,30 & 3,53 & 1,38 & 2,75 & 1,32 \\
\hline
\end{tabular}

Como se observa na tabela, em média, os atores tendem a atribuir pontuações mais baixas, embora com pouca diferença em relação à pontuação dos “não atores", mas há também casos em que isso se inverte, como no parâmetro que avalia a naturalidade do espaço da situação "celular", que foi percebido pelos atores como mais natural do que pelos "não atores". Outros casos em que essa média se inverte são a avaliação da adequação da ação e da língua, ambas na situação "caneta". Nesses casos, a percepção dos atores apresenta pontuações levemente mais altas em relação às dos "não atores". Cabe dizer, contudo, não só que a diferença é mínima, mas também que todos os valores ficaram acima do valor intermediário da escala Likert (3), representando mais um indício de similaridade entre a avaliação de "não atores" e atores. 
Comparando agora as pontuações atribuídas por cada um dos dois grupos às diferentes situações e observadas parâmetro por parâmetro, podemos constatar que, de fato, apenas em poucos casos há diferenças estatisticamente significantes. Na tabela a seguir (Tabela 7), foram reportadas a diferença entre as médias dos dois grupos e valor $p$, que resultou da comparação entre elas.

Tabela 7 - Comparação ator / "não ator" por parâmetro e situação

\begin{tabular}{|c|c|c|c|}
\hline \multirow{2}{*}{ Parâmetro } & \multirow{2}{*}{ Situação } & \multicolumn{2}{|c|}{ "não ator" - ator } \\
\hline & & $\begin{array}{c}\text { Diferença entre as } \\
\text { médias }\end{array}$ & $p$ \\
\hline \multirow[t]{4}{*}{ Espontaneidade } & Água & ,283 &, 184 \\
\hline & Celular &, 333 &, 118 \\
\hline & Caneta & ,267 & ,211 \\
\hline & Temporal &, 450 & ,035 \\
\hline \multirow[t]{4}{*}{ verossimilhança } & Água & 033 & ,878 \\
\hline & Celular & ,267 & ,219 \\
\hline & Caneta & ,133 & ,539 \\
\hline & Temporal & ,200 & ,357 \\
\hline \multirow[t]{4}{*}{ espaço - naturalidade } & Água &, 300 &, 140 \\
\hline & Celular &,- 017 & ,935 \\
\hline & Caneta &, 100 & ,622 \\
\hline & Temporal &, 217 & ,286 \\
\hline \multirow[t]{4}{*}{ espaço - adequação } & Água & ,283 &, 170 \\
\hline & Celular &,- 033 &, 872 \\
\hline & Caneta &, 283 &, 170 \\
\hline & Temporal &, 050 & ,808 \\
\hline \multirow[t]{4}{*}{ ação - naturalidade } & Água & ,417 &, 061 \\
\hline & Celular & ,283 & ,203 \\
\hline & Caneta &, 017 & ,940 \\
\hline & Temporal & ,283 & ,203 \\
\hline
\end{tabular}




\begin{tabular}{|l|l|c|c|}
\hline ação - adequação & água &, 450 &, 032 \\
\cline { 2 - 4 } & Celular &, 167 &, 427 \\
\cline { 2 - 4 } & Caneta &,- 100 &, 634 \\
\cline { 2 - 4 } & Temporal &, 267 &, 240 \\
\hline \multirow{4}{*}{ língua - naturalidade } & água &, 317 &, 152 \\
\cline { 2 - 4 } & Celular &, 133 &, 546 \\
\cline { 2 - 4 } & Caneta &, 183 &, 407 \\
\cline { 2 - 4 } & Temporal &, 200 &, 339 \\
\hline \multirow{3}{*}{ língua - adequação } & água &, 200 &, 524 \\
\cline { 2 - 4 } & Celular &, 133 &, 937 \\
\cline { 2 - 4 } & Caneta &,- 017 &, 473 \\
\cline { 2 - 4 } & Temporal &, 150 &, 360 \\
\hline
\end{tabular}

$\mathrm{Na}$ coluna onde estão reportadas as diferenças entre as médias, confirma-se o que já observamos na tabela anterior: com apenas quatro exceções (evidenciadas em cinza), as médias dos "não atores" são maiores das médias dos atores. Observando os valores de $p$, nota-se que apenas duas vezes há avaliações de "não atores" e atores que mostraram diferenças significantes $(p<0,05)$ : (1) na "espontaneidade" da situação "temporal" $(p=0,035)$; (2) no parâmetro "açãoadequação" da situação "água" ( $p=0,032)$. Há, ainda, na situação "água”, uma avaliação em que se observa uma tendência à diferença $(\mathrm{p}=0,061)$, desta vez, no critério "açãonaturalidade".

Passemos à avaliação geral dos dois grupos, dividida, desta vez, por vídeo (Tabela 8). O teste estatístico utilizado foi o General Linear Model (GLM) com uma variável, que serviu para comparar as pontuações gerais atribuídas a cada um dos vídeos pelos dois grupos de avaliadores ("não atores" e atores). 
Tabela 8 - Avaliação geral dos grupos por vídeo (V)

\begin{tabular}{|c|c|c|c|c|}
\hline $\begin{array}{c}\text { VÍDEOS } \\
\text { (dupla e situação) }\end{array}$ & Avaliadores & Média & Desvio Padrão & $p$ \\
\hline \multirow[t]{2}{*}{ V1 (PK) - água } & NÃO ATOR & 3,38 & 0,76 & \multirow{2}{*}{0,054} \\
\hline & ATOR & 2,95 & 0,89 & \\
\hline \multirow[t]{2}{*}{ V2 (VE) - água } & NÃO ATOR & 4,19 & 0,55 & \multirow[t]{2}{*}{0,540} \\
\hline & ATOR & 4,05 & 0,57 & \\
\hline \multirow[t]{2}{*}{ V3 $(\mathrm{LM})$ - celular } & NÃO ATOR & 2,99 & 0,86 & \multirow{2}{*}{0,153} \\
\hline & ATOR & 2,67 & 0,87 & \\
\hline \multirow[t]{2}{*}{ V4 $(\mathrm{NG})$ - celular } & NÃO ATOR & 3,75 & 0,83 & \multirow{2}{*}{0,985} \\
\hline & ATOR & 3,85 & 0,85 & \\
\hline \multirow[t]{2}{*}{ V5 $(\mathrm{NG})$ - caneta } & NÃO ATOR & 4,00 & 0,94 & \multirow{2}{*}{0,882} \\
\hline & ATOR & 3,97 & 0,89 & \\
\hline \multirow[t]{2}{*}{ V6 (LM) - caneta } & NÃO ATOR & 3,56 & 0,95 & \multirow[t]{2}{*}{0,414} \\
\hline & ATOR & $\mathbf{3 , 3 8}$ & 1,01 & \\
\hline \multirow[t]{2}{*}{ V7 (PK) - temporal } & NÃO ATOR & 2,73 & 0,83 & \multirow[t]{2}{*}{0,124} \\
\hline & ATOR & 2,38 & 1,02 & \\
\hline \multirow[t]{2}{*}{ V8 $(\mathrm{VE})$ - temporal } & NÃO ATOR & 3,55 & 0,92 & \multirow{2}{*}{0,629} \\
\hline & ATOR & 3,44 & 0,99 & \\
\hline
\end{tabular}

As duplas PK e NG foram formadas por "não atores", enquanto as duplas VE e LM, por atores.

Uma vez que o valor intermediário da escala Likert empregada na avaliação do questionário é 3 (lembramos que a escala previa a pontuação mínima 1 e máxima 5), inicialmente, podemos identificar que a todos os vídeos foram atribuídas pontuações médias acima ou levemente abaixo desse valor (o valor médio mais baixo registrado é 2,38 e o mais alto 4,19). Podemos observar as avaliações atribuídas pelos dois grupos aos oito vídeos, também no gráfico a seguir (Gráfico 1). 
Gráfico 1 - Comparação da avaliação de atores e não atores em cada role play

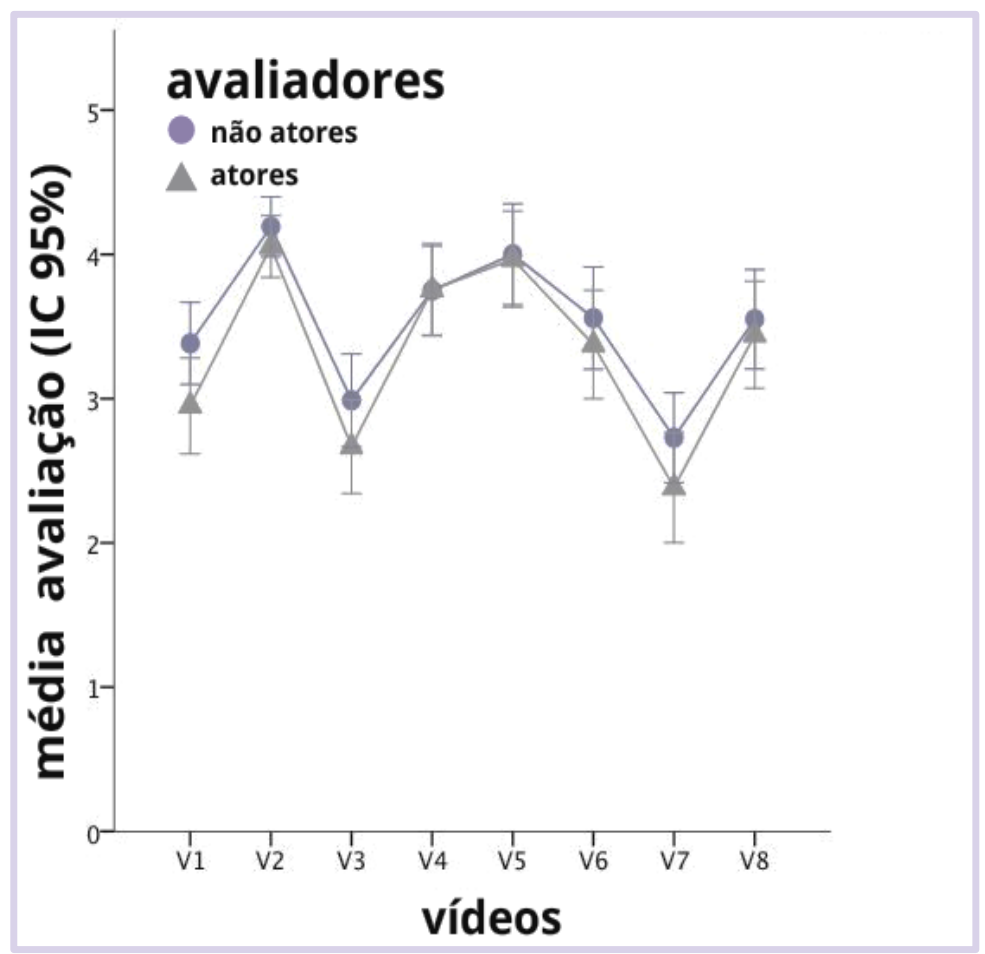

Legenda: IC - intervalo de confiança ${ }^{32}$

O gráfico considera todos os vídeos e inclui cada um dos oito parâmetros de avaliação, separando apenas entre atores e "não atores" e mostrando, assim, que as médias seguem o mesmo padrão. Observando o gráfico e a tabela 8, vê-se que apenas no vídeo 1 (V1), há diferença, ou melhor, uma tendência à diferença estatisticamente significante, entre a avaliação de atores e "não atores" ( $p=0,054)$, enquanto em todos os outros vídeos não há diferenças significantes $^{33}$ ( $p$ entre 0,124 e 0,985 ). O quadro geral mostra, portanto, que há nos grupos uma avaliação convergente, o que se confirma também constatando que a média geral dos atores foi 3,32 e a dos "não atores" 3,52. No entanto, o fato de os atores terem atribuído, às vezes, pontuações levemente inferiores em relação aos "não atores" pode ser indício, como já mencionamos anteriormente, de que o olhar mais apurado dos atores pode notar detalhes nem sempre captados pelos "não atores", confirmando o que aponta também a literatura sobre o tema (GOFFMAN, 1981). De qualquer maneira, em ambos os grupos, a avaliação média acima de 3, o valor intermediário proposto, sugere que houve uma tendência a considerar espontâneas,

\footnotetext{
$32 \mathrm{O}$ intervalo de confiança (IC) mostrado na tabela indica o nível de confiabilidade de uma estimativa.

${ }^{33}$ Nos gráficos de comparação das médias, as barras de erro representam a variabilidade interna da amostra.
} 
verossímeis, naturais e adequadas todas as representações submetidas ao julgamento, não importando se haviam sido gravadas por "não atores" ou por atores.

A pontuação média mais baixa, tanto dos julgadores "não atores" $(2,73)$ quanto dos atores $(2,38)$, foi recebida pelo vídeo 7 (V7), em que a participante chega à casa da amiga dizendo que está encharcada e pedindo para se enxugar ou tomar um banho, pois fora está chovendo muito. Nesse vídeo, a situação é encenada por "não atores" e a justificativa da avaliação mais baixa poderia estar no alto grau de imposição da situação (GI+) e na dificuldade de representar o que foi proposto à dupla, mantendo a verossimilhança. Segundo um dos informantes (inf. 45, ator) indicou na parte aberta do questionário, "atores são extremamente naturais em relação a situações estranhas tipo aparecer na casa de alguém molhado e pedir para tomar um banho" [Attori sono troppo naturali rispetto a situazioni strane tipo piombare in casa di qualcuno bagnati e chiedere di farsi una doccia]. De fato, a mesma situação do temporal foi encenada também por atores (V8) e recebeu uma pontuação geral mais elevada, o que pode indicar que, embora todos possam encenar, como afirma Goffman (1981), atores estendem essa capacidade cotidiana e a desenvolvem de forma mais consciente. Outro fato que pode ter causado essa avaliação é que a situação foi recriada com a participante que "finge" estar molhada de chuva, enquanto, na mesma situação, o ator se molha "de verdade" para gravar a cena. Sobre esse aspecto, na parte aberta do questionário, em que se perguntava sobre o que havia guiado a atribuição da pontuação, o informante 40, um ator, escreveu o seguinte:

Credibilidade entre movimento, palavra, ação e sobretudo situação. Alguém encharcado: a) deve estar encharcado e, além disso, não se move livremente pela casa de um anfitrião.

[Credibilità tra movimento, parola, azione e soprattutto situazione. Uno fradicio: a) deve essere fradicio, e poi non si muove per la casa di un ospite liberamente.]

Uma pontuação abaixo da média geral, indicando, provavelmente, um menor grau de naturalidade, foi identificada também no terceiro vídeo (V3), gravado com atores, no qual a participante pede emprestado o celular do interlocutor para fazer uma ligação interurbana. Para o grupo dos "não atores", a pontuação média foi 2,99, enquanto os atores atribuíram pontuações levemente mais baixas, chegando à média 2,67. A mesma situação do celular foi gravada também por uma dupla de participantes "não atores" (V4) e, desta vez, o resultado foi inverso, pois a avaliação foi superior em relação ao V3, sendo a média da avaliação do grupo dos "não atores" 3,75 e a dos atores 3,85 (note-se que se trata do único caso, em que a média dos 
avaliadores atores é superior àquela dos "não atores").

Por outro lado, dentre todos os vídeos, a média mais alta foi a obtida pelo V2, ao qual os "não atores" atribuíram a pontuação média 4,19 e os atores 4,05. Trata-se do RP gravado com atores profissionais que mostra a participante chegando com sede na casa de um amigo e pedindo água. No RP correspondente, feito por "não atores" (V1), a média foi mais baixa: 3,28 na avaliação dos "não atores" e 2,95 na dos atores. A pontuação menor poderia ser justificada pelo modo como alguns dos elementos da cena (cenário, ação, palavras e expressões utilizadas) foram percebidos pelos avaliadores, questão que será discutida mais adiante.

Embora essa primeira observação sobre os dados gerais mostre certa diferença na percepção da naturalidade dos vídeos, para verificar a significância da diferença e de que maneira ela se sustenta, foram realizadas análises mais detalhadas que serão ilustradas nas próximas seções.

Antes de passar a essas análises, nas quais ilustraremos os dados parâmetro por parâmetro, observamos aqui como foi julgado cada um deles. $\mathrm{O}$ primeiro era o da espontaneidade da encenação e o segundo, o da verossimilhança da situação encenada. A partir do terceiro, todas as dimensões foram subdivididas em naturalidade e adequação, de modo que havia duas perguntas sobre espaço (3 e 4), duas sobre ação (5 e 6) e duas sobre língua (7 e 8).

Considerando todos os vídeos, na tabela a seguir (Tabela 9), reportamos a pontuação geral para cada parâmetro observado no teste.

Tabela 9 - Média geral da pontuação por parâmetro de avaliação

\begin{tabular}{lccc}
\cline { 2 - 3 } & Média & $\begin{array}{c}\text { Desvio } \\
\text { padrão }\end{array}$ & N \\
\hline Espontaneidade & 3,31 & 1,215 & 480 \\
Verossimilhança & 3,26 & 1,243 & 480 \\
Espaço (naturalidade) & 3,82 & 1,119 & 480 \\
Espaço (adequação) & 3,80 & 1,134 & 480 \\
Ação (naturalidade) & 3,24 & 1,261 & 480 \\
Ação (adequação) & 3,29 & 1,189 & 480 \\
Língua (naturalidade) & 3,30 & 1,267 & 480 \\
Língua (adequação) & 3,35 & 1,194 & 480 \\
\hline
\end{tabular}

Com a avaliação de todos os critérios, verifica-se que a média, resultante das pontuações, se manteve entre um valor médio mínimo de 3,24, para a naturalidade da ação, e 
um máximo de 3,82, para a naturalidade do espaço. Em geral, todos os parâmetros receberam avaliações que podem ser consideradas médio-altas, por estarem acima da pontuação 3, que é valor intermediário na escala Likert utilizada, e indica que são percebidos como naturais ou próximos da realidade do falante nativo avaliador.

Além disso, verificamos o grau de intensidade da correlação linear entre os parâmetros escolhidos, realizando o teste de correlação de Pearson (Gráfico 2).

Gráfico 2 - Correlação de Pearson entre todos os parâmetros

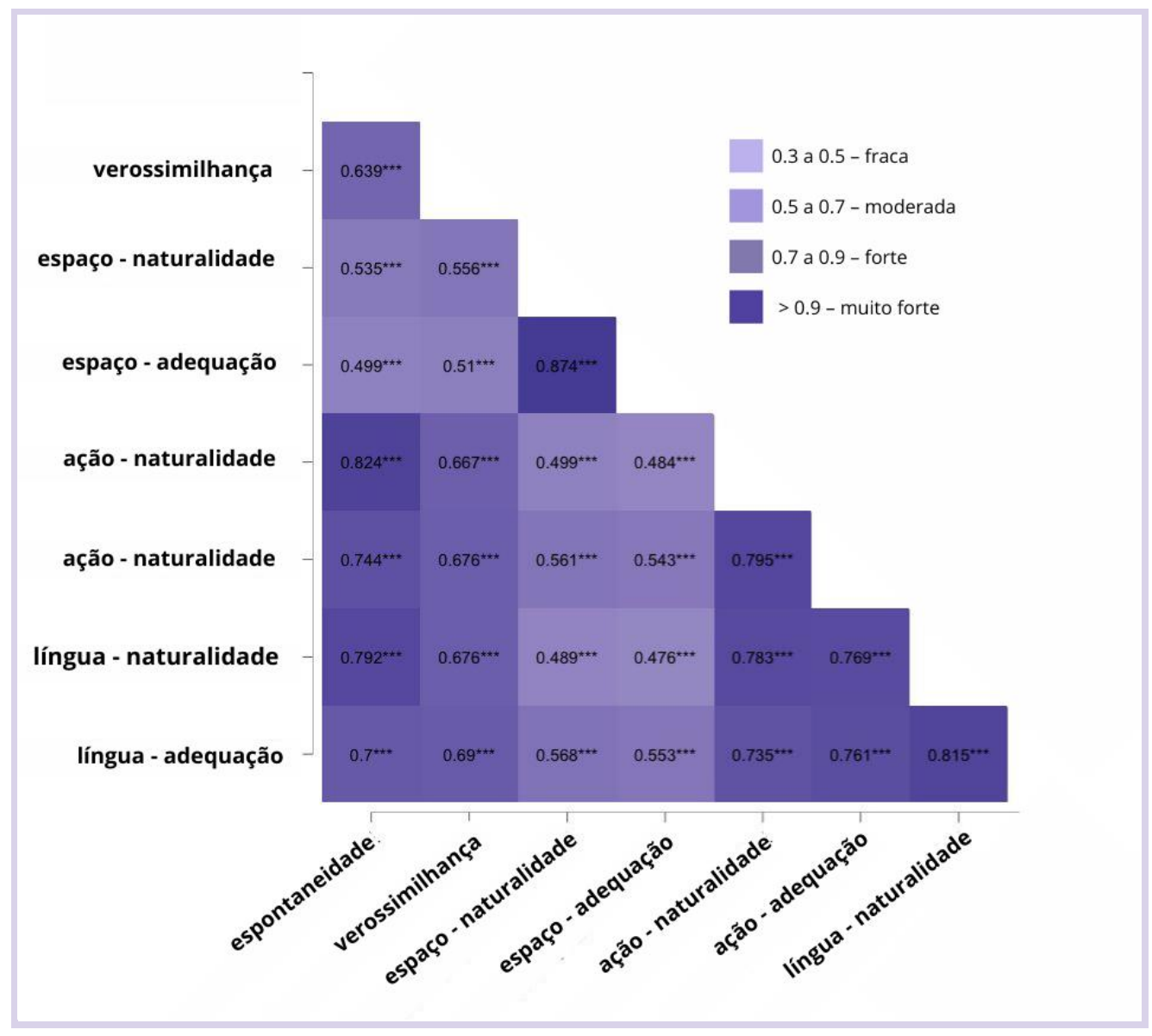

Uma observação preliminar a respeito do teste é que em todos os casos os valores foram obtidos com um $p<0,001$ (indicado no gráfico por ***), o que demonstra a existência de uma variabilidade mínima no interior da amostra e, portanto, que os resultados podem ser generalizados, podendo-se partir do pressuposto que também com outros informantes os valores seriam os mesmos.

Quantos aos índices, o teste mostra que existe uma correlação de moderada a forte entre todos os parâmetros escolhidos (a correlação é mais forte quanto mais se aproxima de +1 ), o que indica que as variáveis crescem na mesma proporção, ou seja, que ao aumento de uma 
variável corresponde também o aumento da outra. Esse dado é mais uma prova da robustez do instrumento utilizado e de como os parâmetros escolhidos são relevantes para o estudo que nos propomos. Especialmente elevada é a correlação entre os quatro parâmetros da naturalidade e da adequação da ação e da língua, também fortemente relacionados com espontaneidade e verossimilhança da situação. Ao contrário, os dois critérios relativos ao espaço têm uma correlação muito forte entre si, mas mais fraca quando observados na relação com ação e língua.

Como dissemos, nas seções seguintes, observaremos as avaliações dos dois grupos ("não atores" e atores) de maneira pontual, evidenciando semelhanças e diferenças no modo como é percebido cada parâmetro, aqui considerado como componente essencial das interações (seja na vida, seja nos RPs). Lembramos que à perspectiva externa ou ética, será unida a perspectiva interna ou êmica, isto é, as respostas das entrevistas retrospectivas, a fim de confirmar se e de que forma as encenações dos vídeos correspondem à realidade dos dois tipos de falantes nativos (participantes dos RPs e não participantes avaliadores).

\subsection{Espontaneidade}

A escolha de aferir a "espontaneidade" como primeiro parâmetro de análise dos vídeos se deu por considerar conceitos e ideias provenientes dos diferentes campos observados no referencial teórico. Como vimos, alguns linguistas defendem unicamente o uso de dados ditos "naturalísticos", o que é também chamado de "conversas espontâneas" e que, segundo pesquisadores como Golato (2003) e Wildner-Bassett (1989), só podem ser retirados da vida cotidiana. Já na obra de Goffman (1975 [1959], 1981), a espontaneidade é elaborada - inclusive, de maneira consciente - pelos indivíduos, enquanto interagem representando papéis e calculando seus movimentos, para serem aceitos e/ou não serem desacreditados pelo interlocutor. Deste modo, a avaliação da espontaneidade se dá pela observação geral da interação entre quem realiza a ação e quem responde a essa ação, à medida que a representação, tanto nos RPs quanto na vida (GOFFMAN, 1975 [1959]), ocorre durante a interação.

Já nas Artes Cênicas, a espontaneidade é algo buscado por diferentes vertentes do teatro, e um dos esforços feitos para que seja atingida é a adoção de técnicas como o uso de roteiros com indicações de cena no lugar do texto teatral, escolha que permite que o indivíduo empregue sua realidade na encenação. Partir de roteiros para atingir espontaneidade ou encenações próximas do que ocorre na realidade é uma prática desenvolvida por artistas como Augusto Boal e também pelo grupo Rimini Protokoll (ver $§ 1.4)$. Nessa prática, a cena é ocupada pelos "especialistas do cotidiano": "não atores" que representam a si mesmos dentro da obra de arte. 
No questionário, a espontaneidade dos RPs foi avaliada pelos 60 informantes para cada um dos oito vídeos, com a atribuição de um total de 480 pontuações ( 240 dos "não atores" e 240 dos atores), que ficaram distribuídas como reportados nos dois gráficos a seguir (Gráficos 3 e 4$)$.

Gráfico 3 - avaliação da espontaneidade "não atores"

Gráfico 4 - avaliação da espontaneidade atores
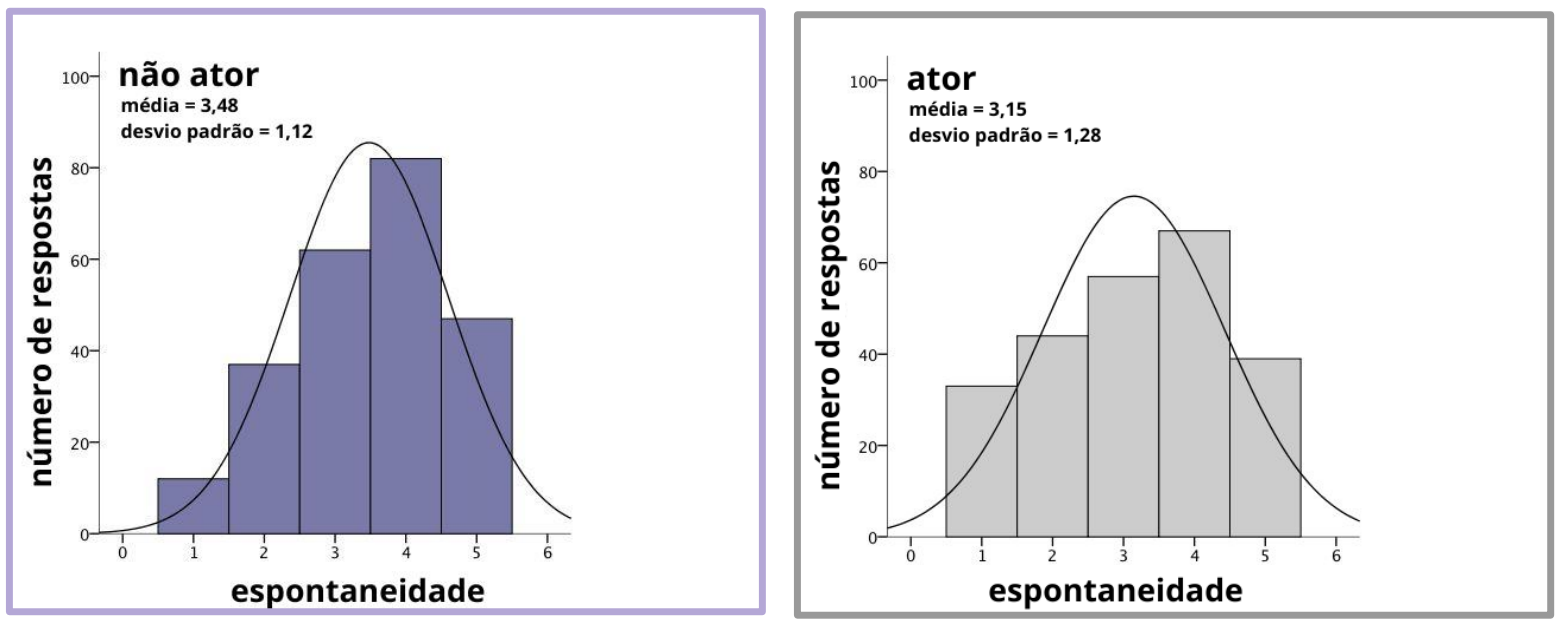

Observando os gráficos, podemos perceber, em primeiro lugar, que as médias de "não atores" $(3,48)$ e atores $(3,15)$ divergem. Como foi mostrado nas análises iniciais, "não atores" conferem uma pontuação para esse parâmetro que resulta mais alta quando comparada com a do grupo dos atores, evidenciando assim uma maior acurácia por parte dos atores na hora de observar e julgar ações cotidianas (GOFFMAN, 1981). No gráfico que mostra a avaliação dos "não atores", pode-se notar que a maior frequência das avaliações está concentrada no nível 4 $(34,17 \%)$, com uma baixa frequência no nível 1 (5\%), o que mostra que os "não atores" perceberam nos RPs um elevado nível de espontaneidade. Ainda com relação a esse parâmetro, na parte aberta do questionário, os "não atores" mencionaram explicitamente a espontaneidade para justificar a pontuação atribuída, como acontece com o informante 29 , o qual escreveu que "a espontaneidade na atuação" ["la spontaneità nella recitazione”] guiou sua escolha. Outra afirmação significativa é a seguinte: “(...) Se não soubesse que já sabiam o que dizer e fazer, teria pensado que fosse um vídeo autêntico" [(...) Se non avessi saputo che sapevano già cosa dire e fare, avrei pensato fosse un video autentico"] (inf. 16, "não ator"), o que revela com clareza a percepção do avaliador. Um detalhe que vale a pena relembrar é que, de fato, quem gravou o vídeo do RP não sabia exatamente o que dizer ou fazer, uma vez que se partia apenas 
da descrição de uma situação comunicativa e isso parece ter colaborado para alcançar um maior nível de espontaneidade.

O gráfico dos atores, embora apresente avaliações mais distribuídas com relação à média e mais pontuações no nível $1(13,75 \%)$ em relação aos "não atores", também concentra a maior frequência de respostas no nível 4 (27,92\%). Embora haja entre eles um nível menor de concordância, a maioria dos atores avalia que os RPs são medianamente ou muito espontâneos. Vejamos duas justificativas para a atribuição da pontuação que foram escritas na parte aberta do questionário:

A espontaneidade e a organicidade nas palavras e nos movimentos.

[La spontaneità e l'organicità nelle parole e nei movimenti.] (inf. 58)

Um ritmo e um tempo percebe-se como espontâneo se não é pré-construído. [Un ritmo e un tempo si percepisce spontaneo se non è pre-costruito.] (inf. 37)

Como prevíamos, o ponto de vista mais "técnico" dos atores na observação das cenas traz novos elementos para a análise da espontaneidade como parte da naturalidade. Tanto o comentário que relaciona fala e movimento, quanto a importância dada a ritmo e tempo e à sua (pré)construção são exemplos disso.

Ainda no parâmetro "espontaneidade", utilizamos as médias para observar comparativamente as avaliações dos dois grupos relativas a cada uma das quatro situações propostas (Gráfico 5). 
Gráfico 5 - médias espontaneidade "não atores" e atores

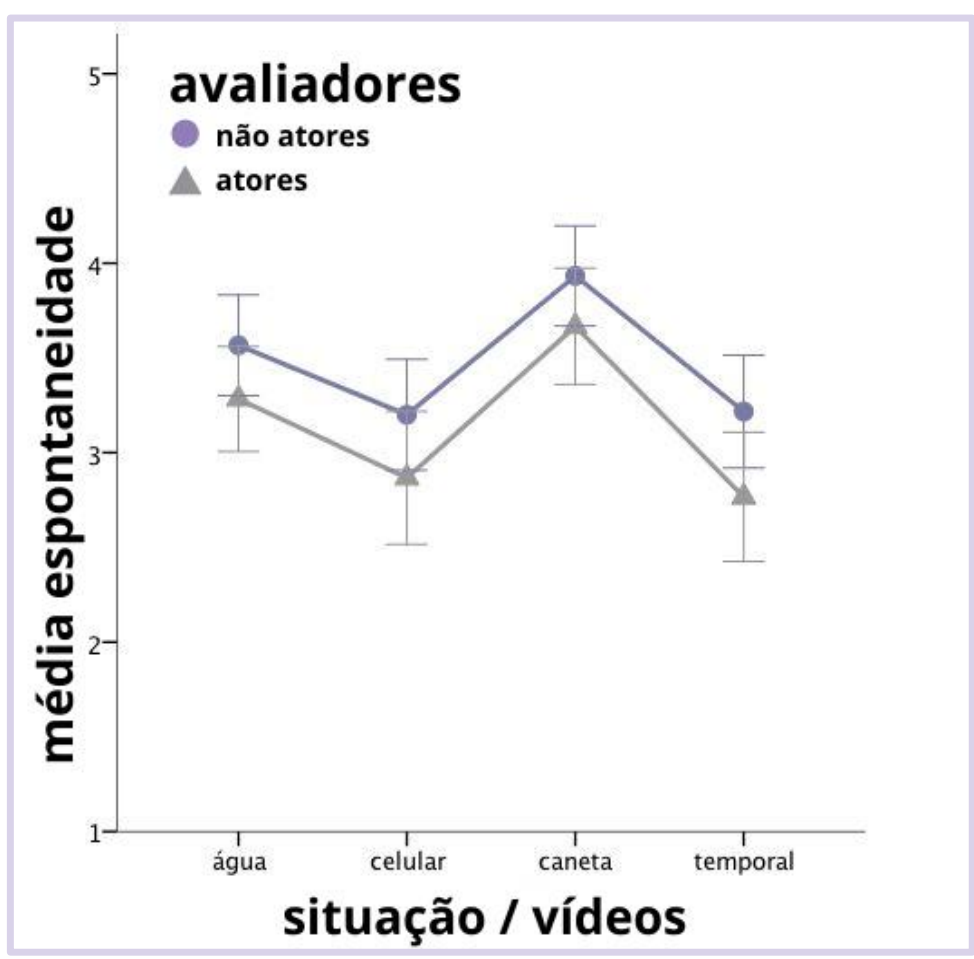

É possível verificar que, embora as médias dos “não atores" sejam mais altas em todas as situações, os dois grupos apresentam a mesma tendência de avaliação, percebendo uma "espontaneidade" maior em situações de baixo grau de imposição (GI-) ("água" e "caneta") e menor nas situações de alto grau de imposição (GI+) (“celular" e "temporal”).

Avaliando ainda a espontaneidade, mas considerando agora a perspectiva êmica ou interna ao processo de coleta dos dados (KÁDÁR \& HAUGH, 2013), selecionamos algumas das considerações dos participantes sobre a percepção de si próprios:

$\mathrm{N}$ : (...) muito espontâneo ... saiu ... falei livremente, não me senti artificial (...). [(...) molto spontaneo... mi è venuto... ho parlato liberamente, non mi sono sentita artificiosa (...).]

P: (...) espontâneo... bom... imagino que mesmo em uma situação sem estar sendo filmada ... um pedido ad hoc eu teria feito assim (...).

[(...) spontaneo ... beh... mi immagino che anche in una situazione senza essere registrata... una richiesta ad hoc avrei fatto così (...).

K: (...) sim, e eu diria que foi bastante espontâneo, aliás, fiquei surpresa que fosse possível fazer isso tão espontaneamente, embora todos nós soubéssemos que era ... que havia a gravação (...). 
[sì, e direi che è stato comunque abbastanza spontaneo, anzi mi sono meravigliata che si riuscisse a farlo così spontaneamente anche se tutti sapevamo che era... che c'era la registrazione (...).]

Como podemos notar, as considerações dos participantes parecem convergir com a percepção da espontaneidade na perspectiva ética dos dois grupos de avaliadores, na medida em que os participantes avaliam as próprias encenações com "muito espontâneas". Contrariando as expectativas, o que muitas vezes se afirma sobre o assunto, nem mesmo o fato de não estarem familiarizados com a presença da câmera ou com a representação "profissional" parece interferir na espontaneidade, tanto que uma participante relata até sua surpresa com essa constatação.

Há mais um aspecto que merece atenção: uma das duplas de "não atores" era composta por amigas de longa data, que, como nas gravações os interlocutores mantinham a mesma relação que tinham na realidade, representaram a si mesmas. Na avaliação de sua própria participação, realizada individualmente e em momentos distintos, ambas as participantes falaram também da "atuação" de sua interlocutora, da qual avaliaram positivamente a espontaneidade. Comparando sua atuação, que assistiram gravada em vídeo, com a realidade disseram:

P: (...) tanto eu como K, teria sido muito similar [na realidade] (...).

[(...) sia io che $K$, sarebbe stato molto simile [nella realtà] (...).]

K: (...) sim é muito próximo e também muito aderente à realidade, acho que muito próximo a uma situação não gravada... acredito que teríamos nos comportado [assim] (...).

$[(\ldots)$ sì è vicino e piuttosto aderente alla realtà secondo me molto simile a una situazione non registrata... io credo che noi ci saremmo comportate [cosi] (...).]

A avaliação do "outro" que aconteceu de forma imprevista ao longo da entrevista é mais um aspecto da perspectiva êmica, citado por Kádár e Haugh (2013), já que, segundo eles, faz parte da avaliação interna não só observar a si próprio, mas também o interlocutor. Essa avaliação da interação é mais uma confirmação do elevado nível de espontaneidade, de modo que todas as avaliações parecem convergir. 


\subsection{Verossimilhança da situação}

Enquanto com o parâmetro da espontaneidade buscamos verificar como são percebidas as representações dos indivíduos a partir da observação da interação, o critério da verossimilhança foi escolhido para analisar a própria situação encenada. Como dissemos, Goffman (1975 [1959]) correlaciona o modo como construímos as encenações da vida à situação na qual a interação ocorre. Na visão do autor e também para Hymes (1972), a situação é um dos elementos que determina mais fortemente o modo como vamos agir, ou seja, como vamos representar os nossos papéis.

A situação é parte daquilo que é também chamado setting (NICKELS, 2006), isto é, o conjunto de informações que, no caso do RP, o participante vai utilizar na hora da "atuação". Levar em conta esse aspecto é essencial, especialmente no sentido de observar se a situação é ou não compatível com a realidade linguística dos falantes. De fato, as críticas à utilização de RPs para investigar fenômenos linguísticos indicam que a falta de verossimilhança estaria relacionada também ao fato de os participantes não terem vivido uma determinada situação na vida real (GOLATO, 2003; WILDNER-BASSETT, 1989) (§ 1.2.1), não tendo, portanto, uma referência clara e uma memória de referência. Ao contrário, nas artes, diretores como Stanislavski apontam que adequamos comportamentos que tivemos ou que já observamos em acontecimentos passados à situação a ser representada, ideia também defendida por Goffman (1975 [1959]) para as representações da vida real.

Perguntados sobre esse aspecto dos RPs, os informantes "não atores" e atores o avaliaram como resumimos nos seguintes gráficos (Gráficos 6 e 7).

Gráfico 6 - verossimilhança "não atores"

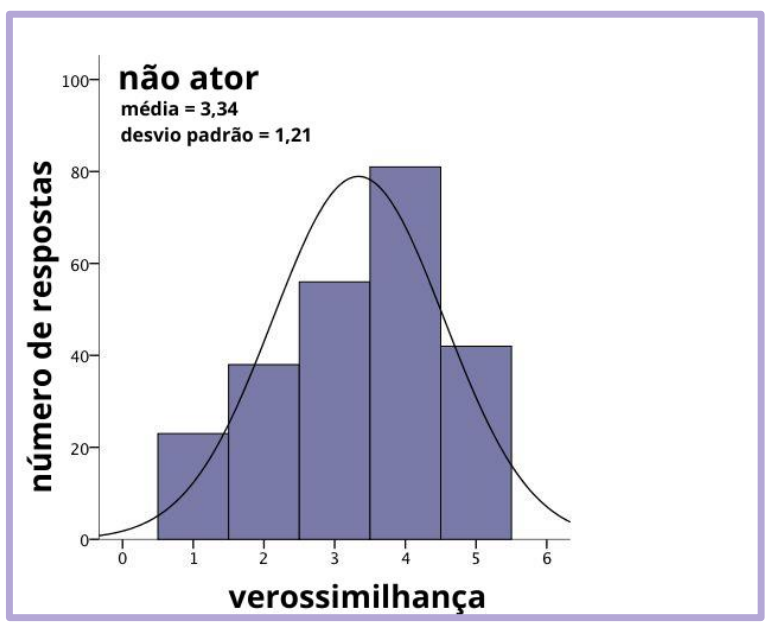

Gráfico 7 - verossimilhança atores

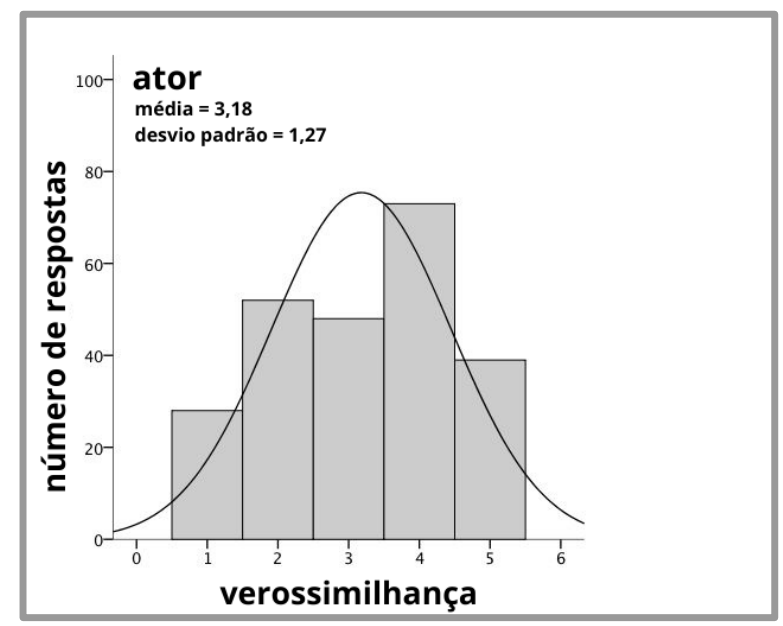


Verificando os gráficos de "não atores" e atores, criados a partir dos valores atribuídos pelos 60 informantes ao parâmetro "verossimilhança" nos oito vídeos, pode-se notar uma tendência parecida àquela apresentada na avaliação na "espontaneidade". Uma diferença é, porém, que a maior frequência de respostas está concentrada no nível 4 em ambos os grupos ("não atores" 33,75\%; atores 30,42\%), o que indica a percepção de um alto grau de verossimilhança, confirmada também pelo número de ocorrências da pontuação máxima (42 de "não atores" e 39 de atores). Nesse critério de avaliação, os atores apresentam, no entanto, menor nível de concordância em relação aos avaliadores "não atores" e o gráfico 7 atores evidencia que uma parte deles atribuiu uma pontuação mais baixa, de modo que a segunda maior concentração de respostas está no nível 2 (21,67\%).

Na parte aberta dos questionários, os "não atores" indicaram que um dos aspectos que guiou o modo como avaliaram os vídeos foi justamente a proximidade da situação encenada a cenas já vividas na vida real. Vejamos dois exemplos.

O fato de o que vi e senti ser próximo de uma situação real.

[Il fatto che quanto vedevo e sentivo fosse vicino ad una situazione reale.] (inf. 20, "não ator")

A aderência às situações semelhantes já vivenciadas.

[L'aderenza a situazioni simili già vissute.] (inf. 30, "não ator")

Nas justificativas dadas pelos atores, chama a atenção, mais uma vez, o olhar mais "técnico", que procura analisar diferentes aspectos, coloca em evidência linguagem corporal e linguagem verbal e relaciona características como naturalidade, plausibilidade e credibilidade. Transcrevemos aqui dois exemplos.

Em geral, todas as situações, exceto uma, pareciam bastante plausíveis para mim. O elemento mais importante para definir a naturalidade foi a linguagem corporal em formas que considero "cotidianas" e a capacidade de ouvir e reagir ao comportamento dos atores em relação ao comportamento do parceiro.

[In generale tutte le situazioni, eccetto una, mi sono sembrate abbastanza plausibili. L'elemento più importante per definire la naturalezza é stato il linguaggio del corpo in forme che ritengo "quotidiane" e la capacità di ascolto e reazione degli attori rispetto ai comportamenti del partner.] (inf. 38, ator) 
Tentei seguir estritamente os parâmetros exigidos pelas perguntas. Separei o aspecto da credibilidade de "atuação" da plausibilidade da situação. A naturalidade é dada quando a linguagem corporal e a linguagem verbal vão na mesma direção e não fazem coisas diferentes (a menos que seja desejado, por exemplo, é uma atitude inconsciente que se assume quando se mente).

[Ho cercato di attenermi strettamente ai parametri richiesti dalle domande. Ho scisso l'aspetto di credibilità "recitativa" dalla plausibilità della situazione. La naturalezza viene data quando il linguaggio del corpo e quello verbale vanno nella stessa direzione e non fanno cose differenti ( a meno che non sia voluto, per esempio è un atteggiamento inconscio che si assume quando si mente).] (inf. 52, ator)

Cabe observar que a verossimilhança indicada pelos avaliadores está diretamente ancorada às suas experiências prévias, sendo eles atores ou não, e que é justamente por meio delas que eles são capazes de julgar as situações de interação (HYMES, 1964), mesmo quando não fazem parte dela. Além disso, tais considerações mostram que a percepção da verossimilhança se dá a partir de uma relação que se estabelece entre as ações e a língua utilizadas nas representações, que veremos melhor mais adiante.

Gráfico 8- médias verossimilhança "não atores" e atores.

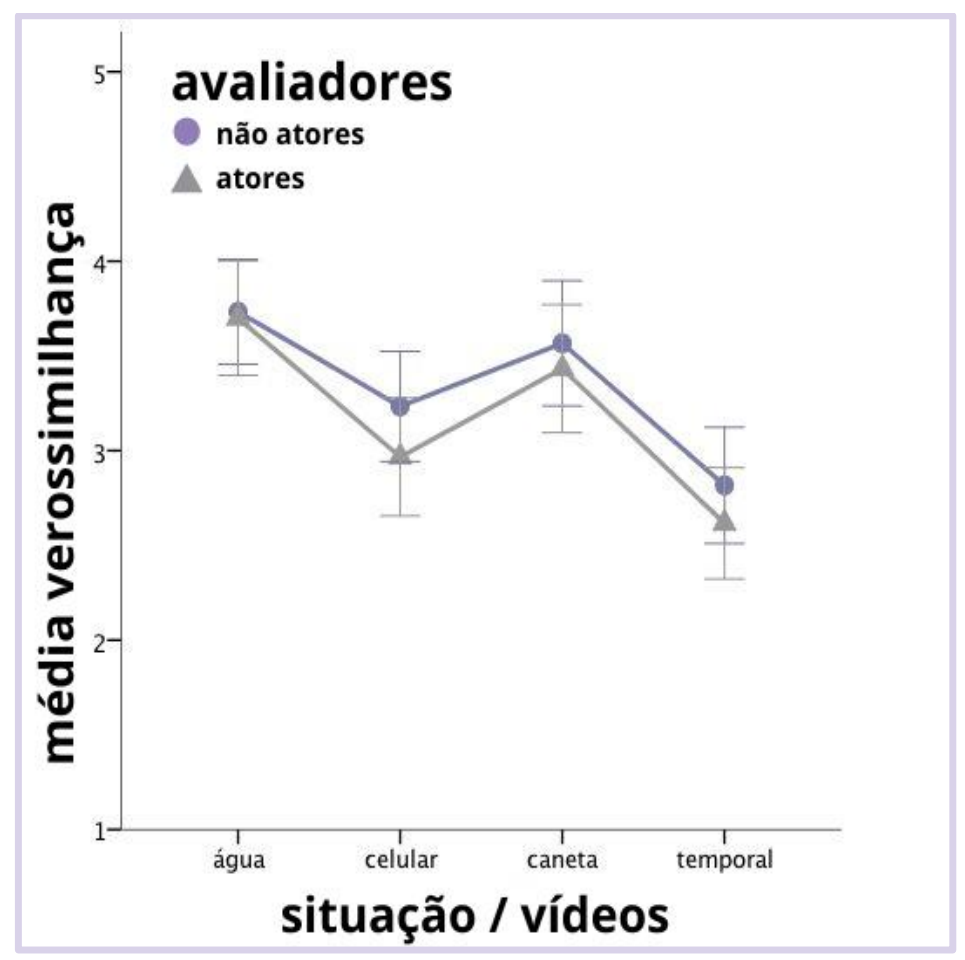

O gráfico 8, que compara as médias dos grupos "não atores" e atores no que concerne 
à verossimilhança da situação representada, mostra que situações de baixo grau de imposição (GI-) (“água" e "caneta”) são percebidas pelos dois grupos como mais verossímeis em relação às situações de alto grau de imposição (GI+) ("celular" e "temporal”). Se observarmos, por exemplo, a situação “água”, os valores dos dois grupos são muito próximos e indicam uma elevada verossimilhança, que diminui na situação "caneta" e chega aos níveis mais baixos nas situações "celular" e "temporal".

Pode ajudar a entender melhor as razões que levaram a avaliar a situação "temporal" como menos verossímil, ler o que escreveu um dos atores a esse respeito:

(...) não achei natural o pedido de tomar banho assim que se entra em casa, um pouco pela coisa em si, um pouco porque não parecia uma amizade tão próxima a ponto de tornar natural a ação entre as duas duplas.

[(...) Non ho trovato naturale la richiesta di fare una doccia appena entrati in casa un po' per la cosa in sé un po' perché non sembrava un'amicizia così stretta da rendere l'azione naturale fra le due coppie di persone.] (inf. 44, ator)

A justificativa dada evidencia que é a própria situação encenada a interferir diretamente na percepção da verossimilhança e a fazer parecer o RP, tanto da dupla de atores quanto da dupla de "não atores", afastado da realidade.

Podemos pensar que observações como essa tenham levado os atores a avaliarem os RPs como menos verossímeis. Contudo, também aqui, essa diferença não é significante em nenhuma das avaliações.

Diferente foi a avaliação dos participantes que nas entrevistas retrospectivas também foram chamados a avaliar a verossimilhança das situações que encenaram. Enquanto, como acabamos de ver, as avaliações quantitativas mostram a situação "temporal" (GI+) como a menos verossímil, as participantes $\mathrm{P}$ e $\mathrm{K}$ declararam já ter vivido a mesma situação ou uma parecida e confirmaram que para elas - em sua cultura - essa situação seria plausível. Reportamos a seguir um trecho das duas entrevistas.

K: (...) mas eu não ... a situação em si não criaria problemas para mim porque... você é uma pessoa que chega ... coitadinha ... encharcada, pega por uma chuva torrencial... você tenta ajudá-la ... já aconteceu comigo de chegar assim, agora me lembro ... cheguei uma vez na casa da A. porque tinha começado a chover muito e a gente estava encharcada, só a parte do caminho do ônibus para o apartamento era uma coisa doida ... acho que... não sei se lá tomamos banho, mas A com certeza ela me enxugou (...). 
[K: (...) però non mi... non mi creerebbe problemi la situazione di per sé perché sei una persona che arriva... poveraccia... bagnata fradicia sorpresa da un acquazzone cerchi di aiutarla... A me è capitato di arrivare così, adesso mi ricordo... sono arrivata una volta a casa di A. così perché aveva cominciato a piovere talmente forte e eravamo fradici, solo il pezzetto dall'autobus all'appartamento era una cosa pazzesca... infatti mi sa che.... non so se ci siamo fatti la doccia però A di sicuro mi aveva asciugata (...).]

P: (...) sim ... já aconteceu comigo talvez entrando... em casa... ou em outro lugar fechado depois de pegar uma chuva torrencial. Com certeza já me aconteceu muitas vezes (...) de ter que pedir a um amigo talvez para tomar banho ... ai meu Deus, sabe que não me lembro!? (...) não é uma coisa do dia a dia, mas uma situação que ... em que eu fiquei molhada e me refugiei para pedir ajuda de alguém com certeza, abrigo, já aconteceu ... se eu já pedi ... nessa ocasião pedi para me trocar ... $\operatorname{sim}$... mas $\operatorname{sim}$... se assim talvez não para tomar banho mas para trocar de roupa, isso sim (...).

[P: (...) sì... mi è già capitato magari entrando.... a casa... oppure in un altro luogo chiuso dopo essermi presa un acquazzone. Sicuramente mi è già capitato tantissime volte (...) di dover chiedere a un amico magari di fare una doccia ... oddio sai che non me lo ricordo ! (...) una cosa quotidiana no, ma una situazione che... in cui mi sono bagnata e mi sono rifugiata a chiedere aiuto a qualcuno sicuramente... riparo, è già successo... se ho già chiesto... in quell'occasione ho chiesto di cambiarmi.... sì... ma sì... se così magari non di far la doccia ma di cambiarmi sì (...)]

Embora as entrevistas tenham sido realizadas individualmente, as duas participantes que contracenam juntas (nos vídeos 1 e 7) relatam já ter vivido situações próximas àquela encenada. É interessante perceber, inclusive, que a participante $\mathrm{K}$, antes de relatar sua experiência, descreve genericamente a situação se colocando no lugar de quem recebe a pessoa que se molhou ("papel" que desenvolve na cena) e só então se lembra de ter vivido algo parecido. O movimento feito por $\mathrm{K}$ de buscar na memória situações parecidas para criar uma analogia com a situação que, nesse caso, está analisando, parece demonstrar o funcionamento da memória afetiva estudado por Stanislavski.

No caso da situação "caneta” (GI-), a segunda situação avaliada como mais verossímil pelos dois grupos, e "celular" (GI+), a segunda situação avaliada como menos verossímil, as considerações da outra participante também diferem, de certo modo, do que apontam as avaliações das escalas Likert. Respondendo se já havia vivido algo parecido ou se considerava as situações "celular" e "caneta" verossímeis, a participante explica:

N: Não... bem... digamos... não na rua (...) não me lembro de ter que pedir um celular emprestado para uma situação de emergência ( ...)

[N: No... beh.... diciamo.... non per strada (...) non mi ricordo mai di aver 
dovuto chiedere in prestito un cellulare per una situazione d'emergenza (...)]

$\mathrm{N}$ : (...) agora cada vez menos [verossímil] pelo fato de todos nós termos um celular no bolso e, portanto, podermos fazer anotações diretamente no celular, então a caneta não é mais tão decisiva, digamos (...) agora ficou um pouco menos natural porque, na minha opinião, menos gente anda com caneta no bolso ou na bolsa (...).

[N: (...) adesso sempre di meno perché il fatto che tutti noi abbiamo in tasca un cellulare, e quindi ci possiamo prendere delle, degli appunti direttamente sul cellulare quindi la penna non è più così determinante, diciamo (...) adesso è diventato un po' meno naturale perché, secondo me, meno persone vanno in giro con una penna in tasca o nella borsa (...).]

O relato de $\mathrm{N}$, que não considera muito verossímil nenhuma das duas situações que analisa, mostra que a percepção da verossimilhança da situação pode não estar vinculada apenas ao grau de imposição, mas ao tempo e ao espaço em que ela ocorre. No que diz respeito à situação "celular", mesmo não descartando a possibilidade de ocorrer, $\mathrm{N}$ afirma que nunca viveu uma situação parecida, pelo menos não na rua. Já para a situação "caneta", as considerações são mais gerais e dizem respeito a mudanças na sociedade ao longo dos anos, indicando que a percepção da verossimilhança de uma encenação pode estar vinculada também a elementos externos à própria encenação que no momento de elaboração de um RP deveriam ser considerados.

\subsection{Espaço}

Em primeiro lugar, é preciso dizer que, assim como a situação, também o espaço em que ela ocorre é parte do setting (NICKELS, 2006), a partir do qual os participantes realizam um RP. Trata-se, por um lado, da descrição do espaço dada ao participante do RP (como, por exemplo, quando se diz que a situação acontece na "casa de um amigo") e, por outro, do ambiente escolhido pelo pesquisador para realizar a gravação dos vídeos, que pode coincidir ou não com o setting proposto no roteiro (no caso, por exemplo, em que se recria um ambiente ou se "imagina", ao invés de realmente gravar o vídeo no ambiente descrito) ${ }^{34}$. A escolha de observar o espaço se justifica, pois, segundo Goffman (1975 [1959]), assim como a relação com o interlocutor, a ambientação também teria a função de determinar a maneira como o

\footnotetext{
${ }^{34}$ Apesar de os RPs escolhidos para o presente estudo terem sido gravados no espaço proposto no setting (na rua, na casa de um amigo), ocorre com frequência que pesquisadores precisem recriar o espaço proposto em ambientes como, por exemplo, as salas de uma universidade.
} 
indivíduo vai construir suas representações ou criar seu "papel”. Embora nos RPs escolhidos para a análise manteve-se a relação entre o espaço descrito e aquele em que o vídeo foi gravado, julgamos que seria importante saber se é percebido como natural, na medida em que, sendo um elemento que compõe a representação, seu grau de naturalidade estaria relacionado à naturalidade geral do vídeo. Acreditava nisso também Stanislavski, que, para atingir representações mais verossímeis, partia do estudo do espaço com a elaboração de um cenário que imitasse fidedignamente a vida ou "garantisse o efeito de realidade" (ARRUDA, 2016, p. 217). Já no que diz respeito à adequação desse espaço à situação proposta, retornamos às considerações de Goffman (1975 [1959]): ele sugere que papéis sociais específicos são representados em determinados ambientes, sendo parte do trabalho do indivíduo reconhecer e/ou escolher como agir, se se encontra em um ambiente formal ou, por exemplo, em um bar com amigos.

A seguir, veremos quais foram as avaliações dos dois grupos (Gráficos 9 e 10), lembrando que a dimensão do espaço foi dividida em naturalidade e adequação e que, como para os critérios anteriores, a avaliação foi realizada pelos 60 julgadores para cada um dos oito vídeos, produzindo 480 respostas (240 em cada grupo).

Gráfico 9 - espaço - naturalidade "não atores"

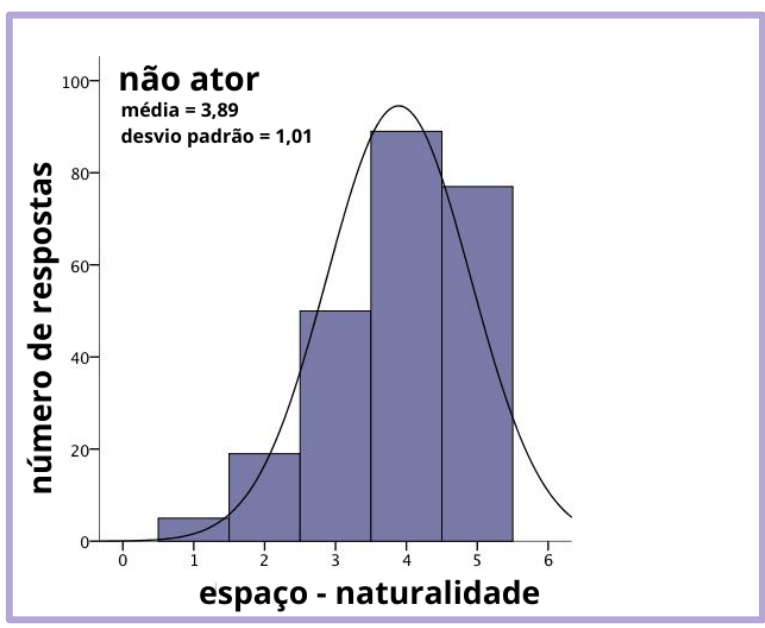

Gráfico 10 - espaço - naturalidade atores

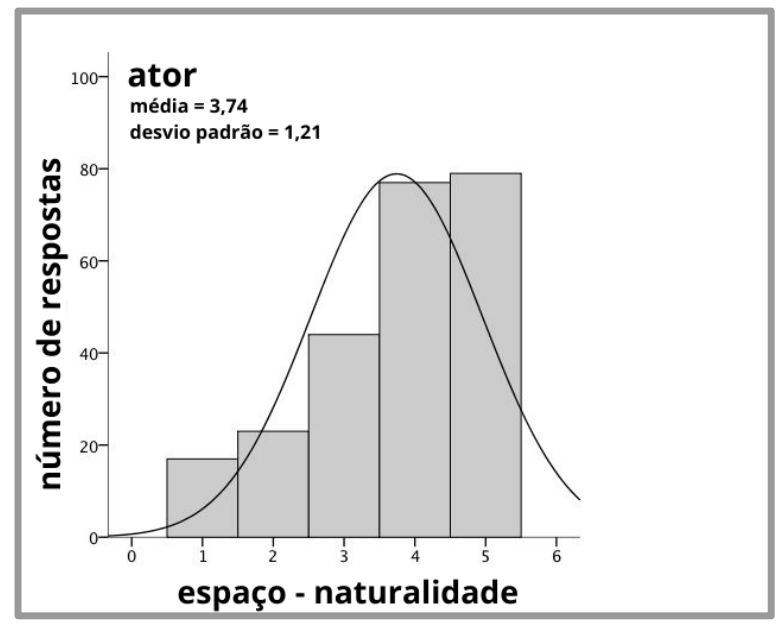

Observando os gráficos correspondentes à naturalidade do espaço, pode-se primeiramente perceber que tanto a avaliação dos "não atores" quanto a dos atores se concentram nas pontuações mais altas da escala Likert. As pontuações 4 e 5 incluem, de fato, a maioria das avaliações e equivalem, juntas, a 65\% respostas dos atores e 69,16\% dos "não atores". É interessante notar ainda que, nesse parâmetro, mesmo com pontuações menos 
concentradas do que os "não atores", o grupo dos atores atribuiu mais vezes a pontuação 5 (o grau mais alto de naturalidade). Não desaparecem, todavia, também ocorrências da pontuação 1, mais frequentes no grupo dos atores, em relação ao grupo dos "não atores". Relembrando que nos RPs escolhidos, todos os espaços são "reais" e não recriados para as gravações, a variação nas avaliações poderia não estar relacionada só ao fato de esse espaço ser/parecer natural, mas a fatores, entre os quais, por exemplo, a percepção dos outros parâmetros que acabam influenciando também o aspecto no qual nos concentramos aqui.

Como para os critérios anteriores, após observar as avaliações dos dois grupos separadamente, fizemos também um gráfico (Gráfico 11), que nos permite observar comparativamente as médias.

Gráfico 11 - médias espaço-naturalidade "não atores" e atores

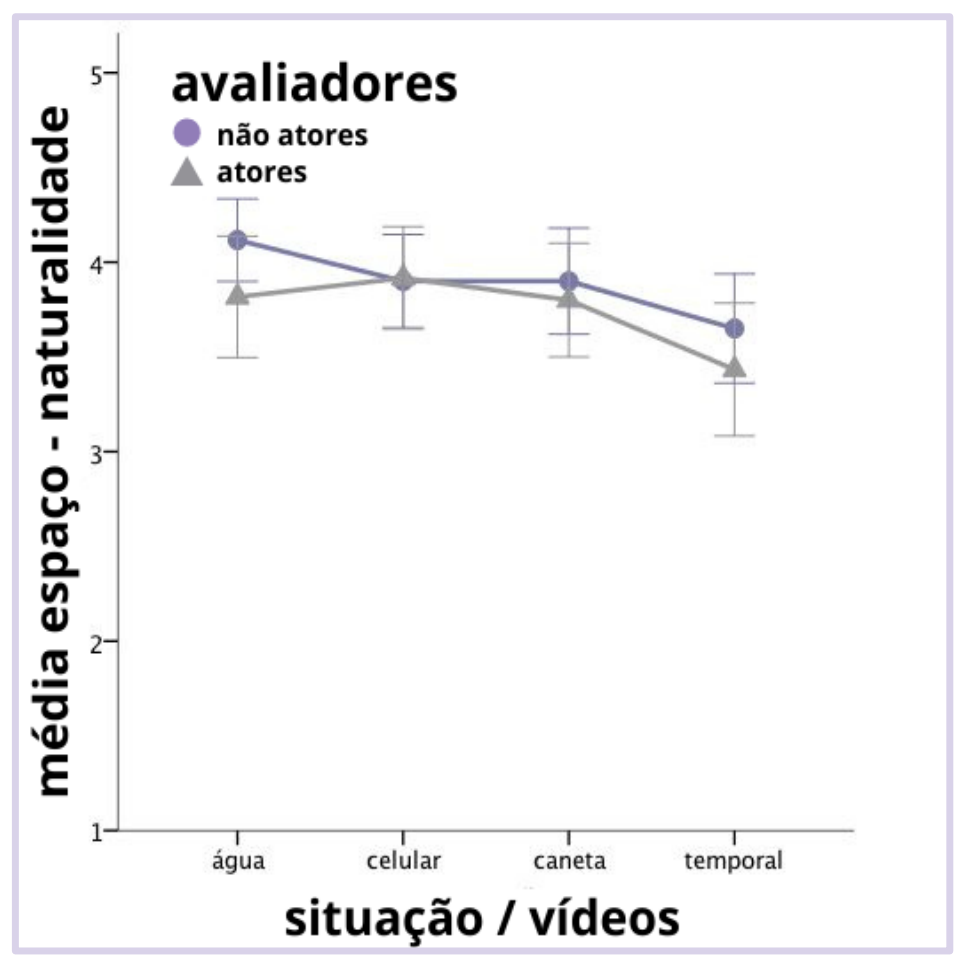


As médias mostram uma relativa concordância entre as avaliações dos dois grupos, mantendo-se sempre acima da pontuação 3 e revelando, portanto, que o grau de naturalidade do "espaço" foi considerado elevado. Os grupos parecem seguir pressupostos diferentes para julgar esse parâmetro em relação ao que observamos nos anteriores. Em primeiro lugar, contrariamente ao que emergiu da análise dos outros dois critérios, as avaliações parecem não estar diretamente relacionadas ao grau de imposição e, portanto, à dificuldade do pedido realizado. Com efeito, as médias da avaliação das situações "celular" (GI+) e "caneta" (GI-) são praticamente idênticas entre elas e, com uma diferença um pouco maior na situação “caneta”, também nos dois grupos. À situação "água” (GI-), os atores atribuíram, em média, uma avaliação semelhante à da situação “caneta”, enquanto os "não atores" julgaram que nesses vídeos a naturalidade do espaço era mais elevada. Para ambos os grupos, a menor pontuação foi atribuída à situação "temporal”, com a média dos atores levemente mais baixa em relação à média dos "não atores". As razões que explicam esse quadro são provavelmente as mesmas que já mencionamos anteriormente: situações percebidas como inusuais acabam recebendo para todos os parâmetros pontuações mais baixas e, embora tenhamos visto que duas das participantes afirmaram já ter vivido algo semelhante, parece que o fato de boa parte dos avaliadores julgar a situação do "temporal" mais distante da realidade influenciou também a avaliação de outros aspectos.

De qualquer maneira, as médias se mantêm muito próximas entre si, assim como nos outros parâmetros avaliados até o momento.

Observando a parte aberta dos questionários, temos a impressão de que os dois grupos utilizem abordagens distintas para analisar a naturalidade do espaço e a justificativa para as diferenças entre eles poderia estar, mais uma vez, em uma maior consciência por parte dos atores em relação aos elementos que compõem uma representação, como mostram os dois exemplos que reproduzimos abaixo, ambos de atores, nos quais o espaço é citado como um dos aspectos que foi analisado separadamente.

Tentar isolar os elementos ação / palavra / espaço em vez de permanecer ancorado em uma percepção geral.

[Cercare di isolare gli elementi azione / parola / spazio invece di rimanere ancorata ad una percezione d'insieme.] (inf. 46, ator, grifo nosso)

Observei principalmente os movimentos do corpo, em relação aos objetos, espaço e pessoas (...) 
[Principalmente ho controllato i movimenti del corpo, in relazione con oggetti, spazio e persone (...)] (inf. 57, ator, grifo nosso)

Passando agora à adequação do espaço em relação à situação proposta, os gráficos seguintes (Gráficos 12 e 13) mostram exatamente a mesma tendência verificada no parâmetro anterior ("espaço-naturalidade"), indicando que o espaço é percebido como muito adequado.

Gráfico 12 - espaço - adequação "não atores”

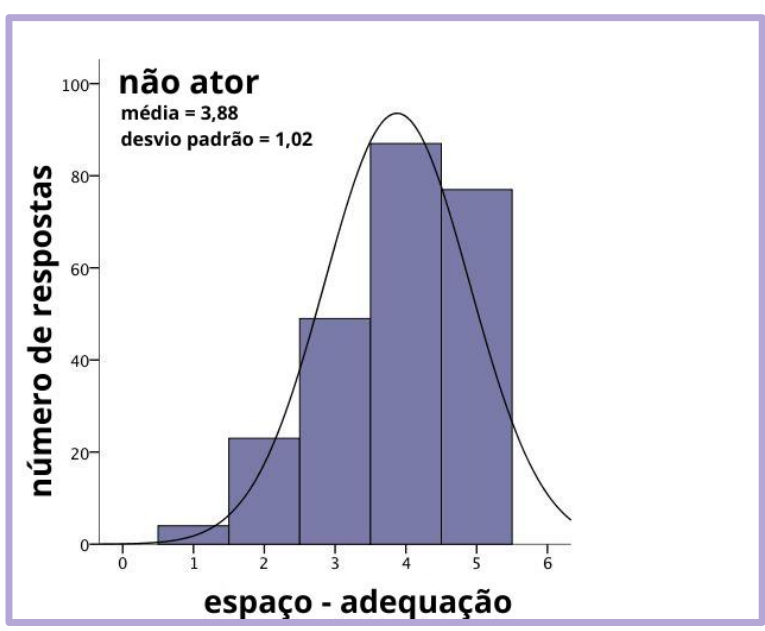

Gráfico 13 - espaço - adequação atores

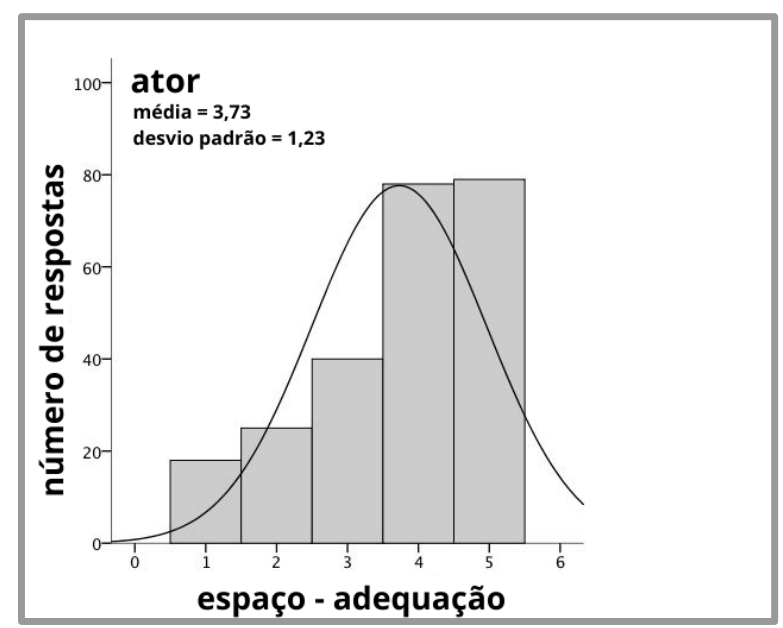

À constatação de que há uma diferença mínima entre as médias dos dois grupos $(3,88$ "não atores" e 3,73 atores), acrescenta-se, com a observação dos dados presentes nos gráficos, que essas médias foram obtidas a partir de uma avaliação muito similar, concentrada nos níveis mais altos da escala. De fato, as pontuações 4 e 5 representam a maioria das respostas em ambos os grupos: 65,42\% para atores e 68,33\% para "não atores". Vejamos para esse critério também a comparação entre as médias, discriminadas a partir das quatro situações (Gráfico 14). 
Gráfico 14 - médias espaço-naturalidade "não atores” e atores

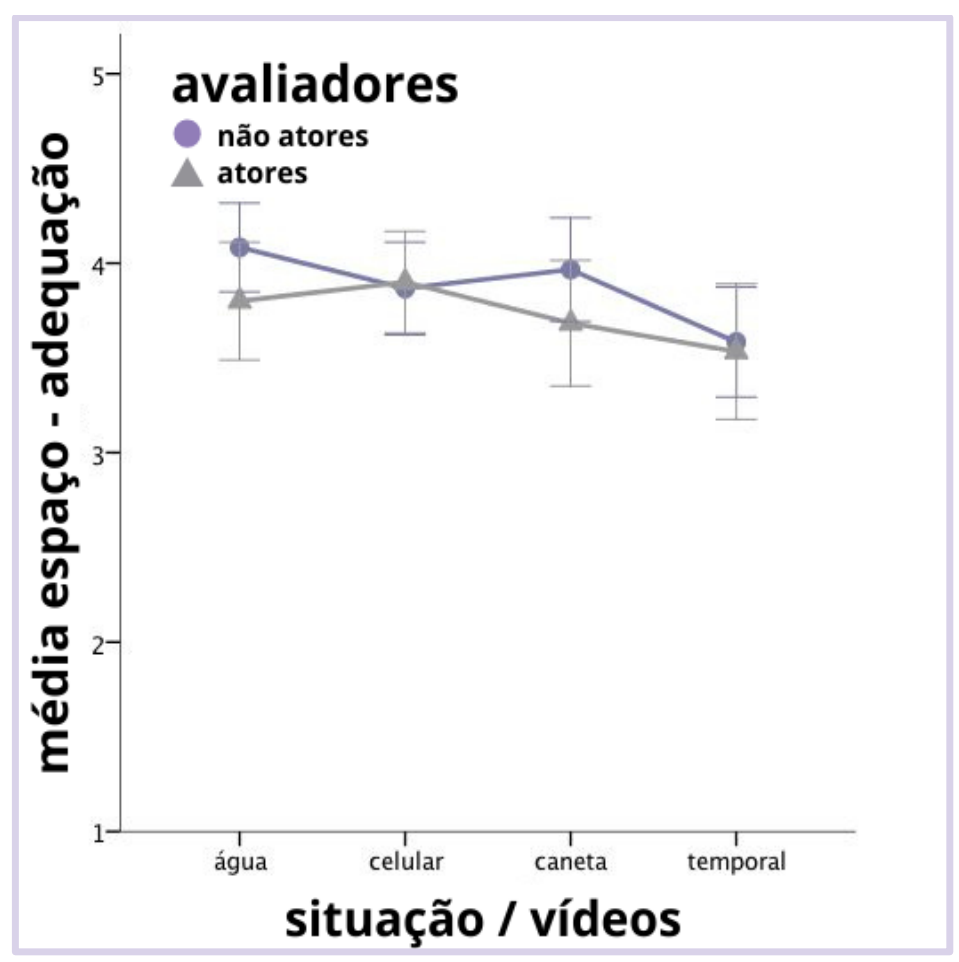

Pode-se perceber que, nesse caso, as médias dos dois grupos apresentam uma concordância quase absoluta nas duas situações de alto grau de imposição, "celular" (atores 3,90; "não atores" 3,87) e "temporal" (atores 3,58; "não atores" 3,53). Nas situações de baixo grau de imposição ("água" e "caneta"), a concordância foi menor, sendo essas situações avaliadas com médias mais altas por "não atores" do que por atores.

Nesse ponto, concorda também um dos participantes dos RPs que em um trecho de sua entrevista coloca em relação espaço e situação e afirma:

G: Sim... pode acontecer que alguém na rua te peça alguma coisa, principalmente a caneta... o celular... é muito mais difícil que alguém peça para usar o teu celular.

[G: Sì... può capitare che qualcuno per strada ti chieda qualcosa, principalmente la penna... il cellulare... è molto più difficile che qualcuno ti chieda l'uso di tuo cellulare.]

A leitura das respostas abertas evidenciou mais uma questão interessante: a tentativa dos atores de avaliar separadamente os diferentes aspectos, enquanto os "não atores" parecem ter atribuído sua pontuação, relacionando apenas espaço e situação. De fato, um dos "não atores" afirma: 
O espaço nunca é um problema: sempre adequado. A naturalidade das situações não é "normal" (...).

[Lo spazio non è mai un problema: adeguato sempre. La naturalezza delle situazioni non è "normale" (...)] (inf. 12, "não ator")

Um ator, por outro lado, escreveu o seguinte:

Observei principalmente os movimentos do corpo, em relação aos objetos, espaço e pessoas (...). O controle do espaço em relação ao enquadramento e o desenvolvimento da interação com a outra pessoa. A opção n. 4 é provavelmente realizada por atores não profissionais e, no entanto, eles excedem em muito as formações amadoras (ou não) das outras opções.

[Principalmente ho controllato i movimenti del corpo, in relazione con oggetti, spazio e persone (...) Il controllo dello spazio in relazione all'inquadratura e lo sviluppo di interazione l'altra persona. L'opzione $n .4$ è probabilmente eseguita da attori non professionisti eppure superano di gran lunga le formazioni amatoriali (o meno) delle altre opzioni.] (inf. 57, ator)

Ficam evidentes aqui os detalhes técnicos resultantes da observação da cena por um ator profissional, confirmando que eles podem fornecer informações adicionais com relação ao modo de analisar as cenas dos RPs. O ator diz ter analisado a percepção do espaço conjuntamente com os movimentos do corpo, com a interação com objetos e pessoas, com a capacidade de levar em conta o enquadramento. É, no entanto, notável que as distintas estratégias utilizadas não cancelam nem a maneira similar de perceber a adequação do espaço verificada nos dados, nem o fato de "não atores" serem capazes de analisar o que lhes parece natural e adequado, baseando-se no que conhecem de suas próprias experiências em situações semelhantes vistas ou vividas.

Nas entrevistas retrospectivas, à pergunta sobre espaço, os quatro participantes confirmaram a elevada adequação e naturalidade percebida pelos julgadores externos. Falando de espaço, $\mathrm{K}$ diz, por exemplo:

bom, isso era muito natural, de qualquer forma, era uma casa... era a casa de B e R, naturalmente... e aí o que acabamos de ver é muito realista porque você pode estar em casa e ter convidado uma amiga que chega com calor... com sede... e te pede algo para beber...

[beh, quello era molto naturale, era comunque una casa... era la casa di B e $R$, naturalmente ... e quindi quello che abbiamo appena visto è molto realistico perché tu puoi essere a casa e aver invitato un'amica che arriva accaldata... assetata... e ti chiede di bere...] 
Sobre a relevância de um espaço adequado para o sucesso da interação, as opiniões eram divergentes. $\mathrm{N}$ afirma não se tratar de um aspecto essencial, enquanto $\mathrm{K}$ avalia que estar no espaço em que uma determinada ação costuma acontecer ajuda quem vai realizá-la. Deixemos a elas a palavra:

$\mathrm{N}$ : (...) do ponto de vista da aparência do vídeo é certamente mais natural ter uma situação desse tipo... mas para mim que tive... que fiz isso... a mim não ajudou, no sentido de que poderia ter me imaginado na mesma situação mesmo em um... em um contexto... em um espaço diferente.

[N: (...) dal punto di vista della resa del video è sicuramente più naturale avere una situazione del genere... ma per me che ho dovuto... che ho fatto questa cosa... non mi ha aiutato, nel senso che avrei potuto immaginarmi la stessa situazione anche in un... in un contesto.. in uno spazio diverso.]

K: ah penso que sim... agora, não tenho a comparação... não sei como seria em um estúdio, digamos... ou em uma sala de aula na universidade ou em outro lugar, mas certamente... naquela situação ajudava... não lembro... havia também situações talvez em um trem ou alguma outra coisa. Então, ali... talvez não ajude... o fato de estar em uma casa... exige mais imaginação (...).

[K: ah penso di sì... adesso non ho il confronto non so come sarebbe stato in uno studio di registrazione per dire... o in una classe all'università o altro, però, sicuramente... per quella situazione aiutava... non mi ricordo... c'erano anche situazioni forse in treno o altro. Ecco lì... magari non ti aiuta, il fatto di essere in una casa... ti richiede più immaginazione (...).]

\subsection{Ação}

Como vimos na obra de Goffman (1975 [1959]), o espaço é uma parte da encenação que, embora esteja relacionada ao indivíduo, não necessariamente depende dele. Diferente disso, a ação e as escolhas linguísticas fazem parte da gama de informações que o indivíduo compartilha com o interlocutor. Embora avaliados separadamente no nosso questionário, esses dois parâmetros constituem as "máscaras" ou as versões de si que o sujeito deseja "mostrar" em determinados ambientes e situações.

Especificamente no que diz respeito às ações, aos gestos e aos movimentos, cabe lembrar que Goffman os considera como informações que o indivíduo "emite" (GOFFMAN, 1975 [1959], p. 12) e que, embora sejam muitas vezes julgadas involuntárias, na verdade, fazem parte tanto das escolhas do indivíduo e de como quer ser visto pelo outro, quanto de imposições sociais relacionadas ao contexto. Na medida em que, nas representações cotidianas, ambiente, situação e interlocutor estão interligados e servem para guiar o indivíduo na construção de como ele "deve" agir, considerar se essas ações são naturais, além de adequadas à situação, não só 
contribui para a percepção da naturalidade dos RPs, mas pode fornecer indícios do que faz ou não parte de uma determinada interação em cada cultura.

Vejamos, então, como as ações presentes nos nossos RPs foram avaliadas pelos dois grupos de participantes (Gráficos 15 e 16).

Gráfico 15 - ação - naturalidade - "não atores"

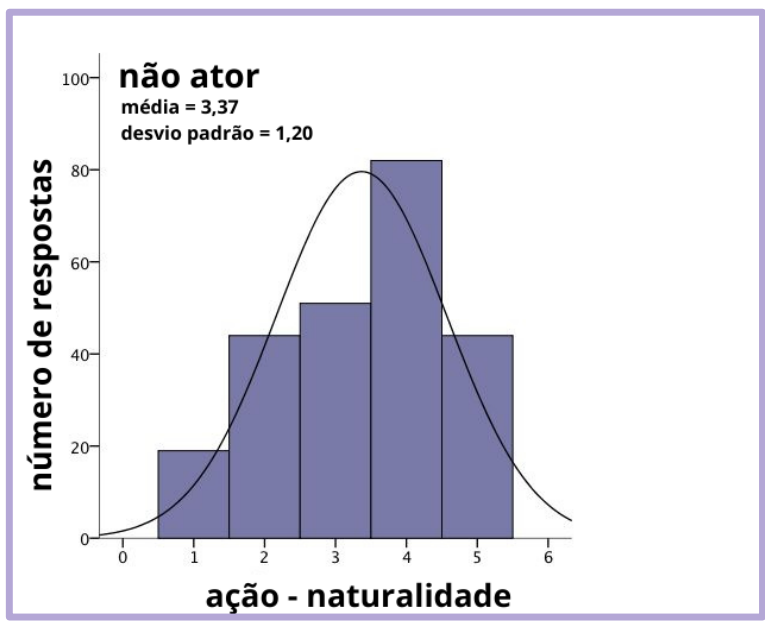

Gráfico 16 - ação - naturalidade - atores

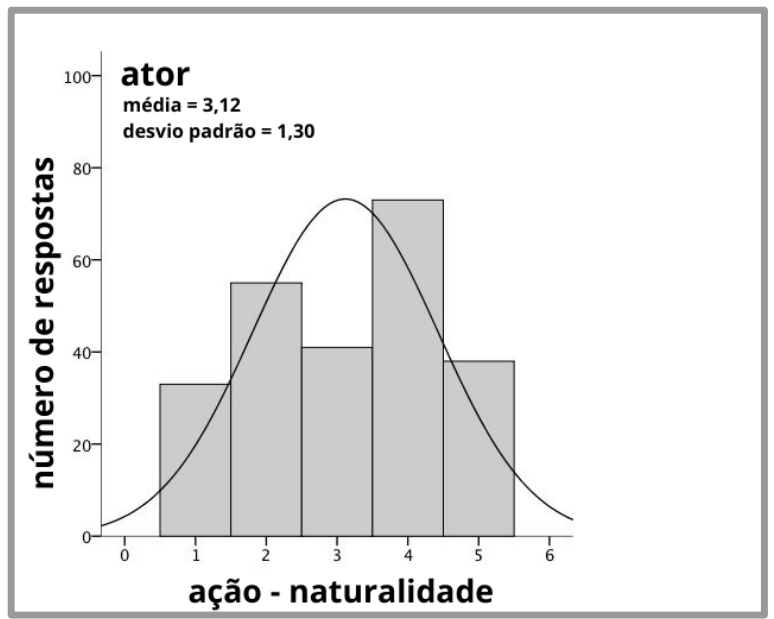

Embora tanto atores quanto "não atores" concentrem o maior número de respostas no nível 4 (30,42\% ocorrências entre os atores e 34,17\% entre "não atores"), considerando o conjunto de dados, observa-se que essa naturalidade é percebida de maneira distinta. Nota-se, por exemplo, que a avaliação dos atores é mais distribuída entre todos os níveis, apresentando a segunda maior frequência de respostas no nível 2, além de ter também no nível 1 - aquele que implica o menor grau de naturalidade das ações - um número de ocorrências não desprezível. Essas informações mostram ainda que atores concordam menos entre eles em relação à naturalidade das ações quando comparados com os avaliadores "não atores".

A parte aberta do questionário evidencia, porém, que tanto atores quanto "não atores" relacionam a naturalidade das ações às escolhas linguísticas, algumas vezes indicando que foi essa combinação que guiou o julgamento dos RPs, como podemos observar nos exemplos reproduzidos a seguir.

A proxêmica me guiou no meu julgamento: muitas vezes acontece que os atores se "traem", ou melhor, dizem algo com o corpo que não corresponde ao que dizem verbalmente. $\mathrm{E}$ em alguns vídeos pude perceber essa desconexão entre palavra e gesto. 
[Mi ha guidato nel giudizio la prossemica: spesso accade che gli attori si "tradiscano", ovvero dicano col corpo qualcosa che non corrisponde a quello che dicono verbalmente. $E$ in alcuni video ho potuto constatare questa disconnessione tra parola e gesto.] (inf. 33, ator)

Certamente comunicação não verbal, mas também elementos (...) como o tom e o ritmo da voz.

[La comunicazione non verbale sicuramente, ma anche elementi (...) come il tono e il ritmo della voce.] (inf. 16, "não ator")

Para o parâmetro "ação", assim como fizemos para os anteriores, procedemos também à comparação entre as médias das avaliações dos dois grupos (Gráfico 17).

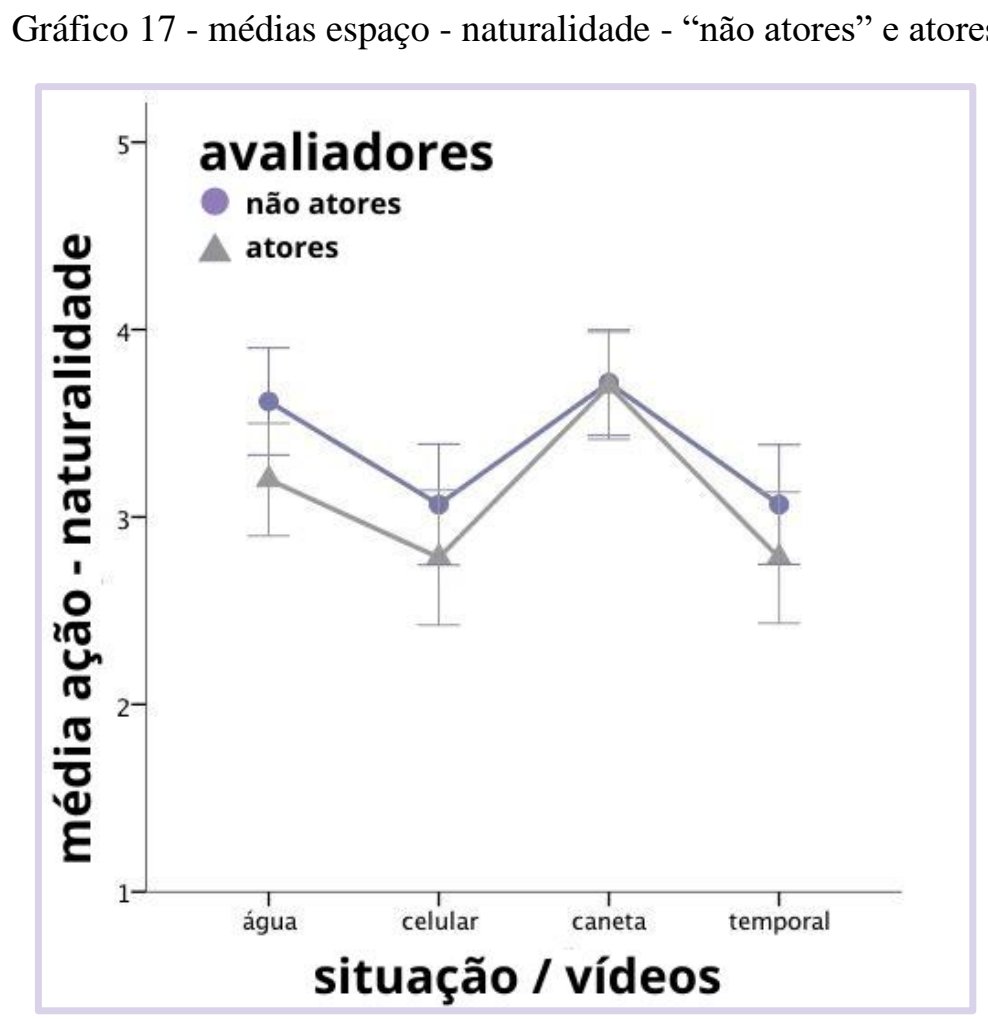

A primeira informação clara que a leitura do gráfico permite é a quase perfeita coincidência na avaliação dos dois grupos da situação "caneta" (atores 3,70; "não atores" 3,72), que é uma das duas situações de baixo grau de imposição (GI-), enquanto na outra ("água") a pontuação média dos grupos se distancia (atores 3,20; "não atores" 3,62). Além disso, é possível notar que também para esse parâmetro se repete a mesma tendência notada nos parâmetros anteriores: situações de alto grau de imposição (“celular" e "temporal”) (GI+) são avaliadas com níveis menores de naturalidade. Outro aspecto que se repete é o fato de a média 
dos atores ser, em geral, mais baixa que a dos "não atores". Cabe notar que, embora atores e "não atores" tenham mantido as avaliações em torno da média, no que diz respeito à naturalidade das ações, as situações de alto grau de imposição são avaliadas pelos atores abaixo da média geral.

Consideremos agora a percepção que duas participantes tiveram de suas próprias ações. Perguntadas sobre se consideram naturais suas ações, responderam assim:

$\mathrm{N}$ : (...) sim porque são ... são parte de mim, então eram muito ... eram naturais e aí, se alguém gesticula muito, gesticula muito, se gesticula um pouco, gesticula um pouco... quer dizer, não me contive, não fiz nada anormal... o gesto, para mim, sempre destaca, ou sublinha alguma coisa, não é? Nesse caso pareciam naturais para mim, sim ... normais (...).

[N: (...) sì perché sono... fanno parte di me, quindi erano molto... erano naturale e poi vabbè, se uno gesticola tanto, gesticola tanto, se uno gesticola poco, gesticola poco... cioè, non mi sono trattenuta, non ho fatto niente di innaturale... il gesto, per me evidenzia sempre, o sottolinea qualche cosa no? In questo caso mi sono sembrati naturali, sì... normali (...).]

P: (...) eu diria muito natural, muito naturais, é um comportamento diário, meu, espontâneo (...).

[P: (...) direi piuttosto molto naturale, molto naturali, è un comportamento quotidiano mio spontaneo (...).]

E ainda:

P: talvez eu me sentisse observada de qualquer maneira e então talvez até o gesto de tocar no meu cabelo foi devido, não sei ... esperando pelo copo d'água, mas também ao fato ... se alguém estava olhando para você de fora (...).

[P: forse mi sentivo comunque osservata e allora magari anche il gesto di toccarsi $i$ capelli è stato dovuto, non so... l'attesa del bicchiere d'acqua ma anche al fatto... se qualcuno ti stava guardando dall'esterno (...).]

A partir das afirmações das participantes, podemos tecer algumas considerações. Em primeiro lugar, os gestos realizados por elas durante os RPs, quando reassistidos após um tempo, são considerados muito naturais e "reais" e, mais que isso, as participantes explicitam que são parte de seu cotidiano e daquilo que elas realmente são ou consideram ser (CROOKALL \& SAUNDERS, 1989). Podemos, a partir dessas falas, pensar que as ações e os gestos que compõem a interação são constitutivos das realidades que esses indivíduos “carregam" para dentro das encenações - no nosso caso, os RPs - e que contribuem para criar a interação, à qual podemos assistir por meio das gravações. Outro detalhe interessante presente na fala de uma das participantes é a referência à consciência de estar sendo "observada", 
acrescentando a isso a avaliação de que suas ações, mesmo guiadas também por isso, se mantiveram naturais. Isso confirma, porém, o que foi afirmado por Goffman (1975 (1959]), de que todos os elementos que compõem a interação - portanto, não apenas o interlocutor, mas também observadores externos (a "plateia") - guiam o modo como representamos. No contexto específico da realização e gravação de RPs, esse componente possui, é claro, ainda mais relevância, mas se trata que acontece sempre que nossas ações acontecem em espaços "públicos”, nos quais a presença de outros não é controlada.

Gráfico 18 - ação - adequação "não atores"

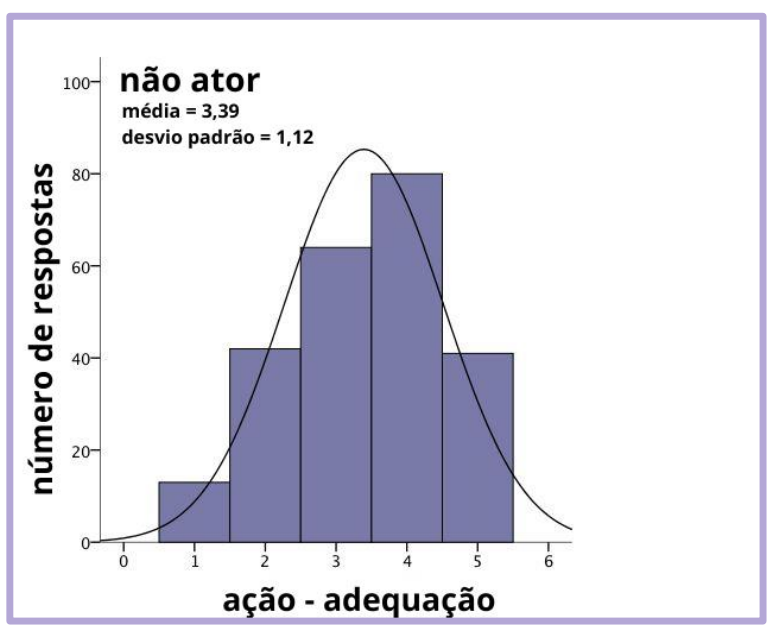

Gráfico 19 - ação - adequação atores

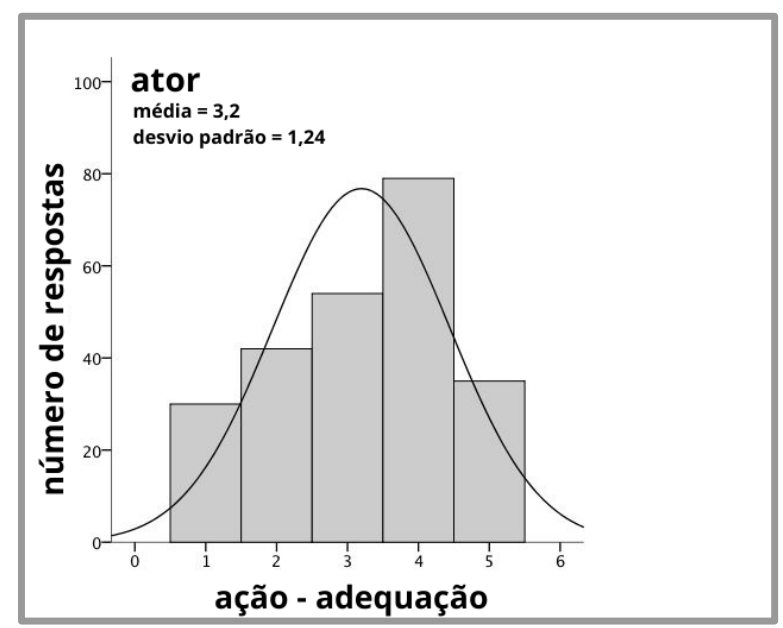

Observando a percepção dos dois grupos de avaliadores no que concerne agora à adequação da ação (Gráficos 18 e 19), constatamos, mais uma vez, que as avaliações se posicionam acima da média estabelecida na escala Likert, em torno do nível 4 (atores 32,92\%; "não atores" 33,33\%). Uma diferença entre as avaliações é que o grupo dos atores considera as ações pouco adequadas duas vezes mais do que o grupo dos "não atores" (a porcentagem do nível 1 é $12,50 \%$ no grupo atores e 5,42\% no grupo "não atores”).

Para observar de forma mais precisa a comparação entre os dois grupos, comparamos as médias para esse parâmetro, obtendo o gráfico reproduzido a seguir (Gráfico 20). 
Gráfico 20- médias ação - adequação "não atores" e atores

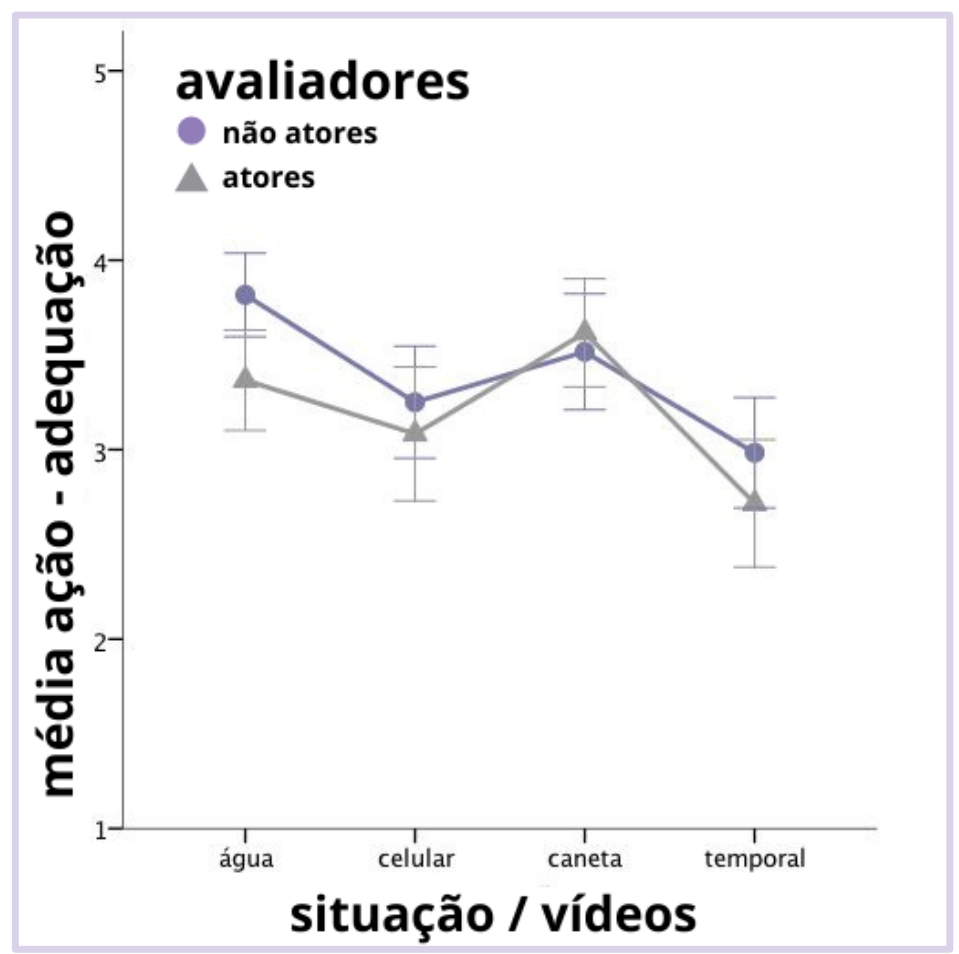

As particularidades das avaliações dos dois grupos ficam aqui ainda mais evidentes. É interessante destacar que, pela primeira vez, a média de uma das pontuações dos atores é mais alta do que a média dos "não atores", como se observa na situação "caneta", de baixo grau de imposição (GI-), à qual atores atribuíram, em média, a pontuação 3,62 e "não atores" 3,52. A tendência, como nos outros casos, é similar e a diferença leve, mesmo assim, chama a atenção o julgamento dos atores nesse quesito.

Outro aspecto que vale a pena ressaltar é que a avaliação da situação "água", também de baixo grau de imposição, recebeu dos dois grupos pontuações que evidenciam uma diferença estatisticamente significante entre elas.

Nas duas situações de alto grau de imposição - "celular" e "temporal" - confirma-se a tendência já observada nos outros parâmetros: os atores atribuem em média pontuações levemente mais baixas do que "não atores", embora mantenham tendências parecidas.

Nas entrevistas retrospectivas, foi feita aos participantes uma pergunta específica sobre como julgavam a adequação das ações ao espaço e à situação. As respostas apontaram para um elevado nível de adequação, colocando-o, inclusive, em relação com espaço e interlocutor, como no caso de P:

P: sim ir direto ao banheiro de uma amiga sim (...) de um estranho não ... (...) não tem nada de estranho, quero dizer, naquele contexto, na casa de alguém que você conhece bem não ... não tem problema, se eu entrasse em um 
restaurante para pedir abrigo ou em um bar ... então ... eu deveria, enfim, deveria dizer pelo menos ... fazer uma premissa diferente dessa (...).

[P: sì andare direttamente in bagno di un'amica sì (...) di uno sconosciuto no.... (...) non c'è nulla di strano, nel senso in quel contesto, a casa di qualcuno che conosci bene no... non c'è problema, se io entrassi in un ristorante a chiedere riparo o un bar... cioè.. dovrei, insomma, dire almeno ... fare una premessa diversa da quella (...).]

Tais considerações também contribuem para confirmar a relação entre a elaboração da representação e o contexto no qual estão contidos tanto o ambiente quanto o interlocutor (GOFFMAN, 1975 [1959]): vê-se que a avaliação leva em conta diferentes aspectos que, juntos, compõem o RP e guiam o modo como é observado. As observações indicam ainda que o momento em que se atua em uma determinada situação é percebido pelos participantes como realidade e, aliás, é a própria realidade (CROOKALL \& SAUNDERS, 1987), tornando-se até, como afirma a participante, uma referência de como ela agiria em uma situação parecida da vida cotidiana.

\subsection{Língua}

No parâmetro que denominamos "língua", subdividido, como os anteriores, em "naturalidade" e "adequação", pediu-se aos avaliadores que voltassem sua atenção ao "dito", isto é, às palavras e expressões escolhidas pelos falantes na interação e que indicassem em que medida essas escolhas lhes pareciam naturais e adequadas a cada situação. Neste trabalho, esse critério é especialmente importante, por ser justamente o que motivou nossa pesquisa, tendo em vista que, como vimos, com grande frequência, a língua eliciada por meio de RPs é considerada não natural e/ou inverossímil por ser uma "língua representada" (GOLATO, 2003; WILDNER-BASSETT, 1989) e, portanto, distante da língua real, mesmo sendo o RP uma interação "verdadeira" entre dois ou mais indivíduos. Pontuamos que, em outras áreas, estudiosos mostram, no entanto, que todas as interações cotidianas acontecem por meio de "representação" ou “encenação" e que delas fazem parte não apenas as ações, mas também as escolhas linguísticas (GOFFMAN, 1975 [1975]). Com efeito, na opinião de linguistas como Caffi (2009), é exatamente por meio das escolhas linguísticas que se dá, por um lado, a própria representação de papéis e, por outro, a construção dos sujeitos, que possuem, em todas as condições, a capacidade de adequar seus discursos aos contextos nos quais interagem (HYMES, 1972; 1964). 
Vejamos agora, como os dois grupos de avaliadores perceberam a "naturalidade da língua", isto é, em que medida consideraram o que foi falado nos RPs não artificial ou construído, mas espontâneo e correspondente à realidade (Gráficos 21 e 22).

Gráfico 21 - língua - naturalidade "não atores”

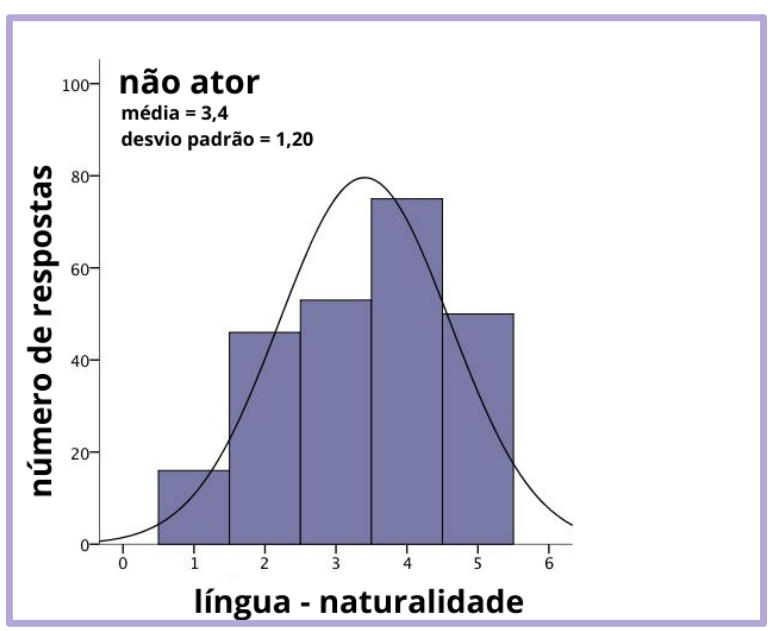

Gráfico 22 - língua - naturalidade atores

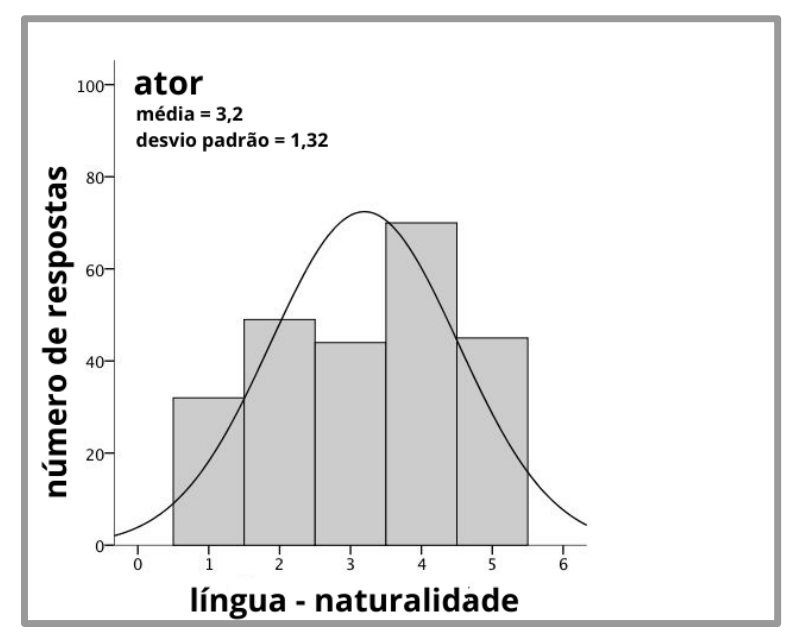

Como podemos observar, a avaliação da naturalidade da língua mostrada no gráfico apresenta a mesma tendência de alguns parâmetros anteriores, com os dois grupos mantendo a maior frequência de respostas no nível 4 (29,2\% para os atores e 31,3\% para os não atores), o que indica que, na opinião dos avaliadores a naturalidade das escolhas linguísticas dos RPs se coloca na parte superior da escala Likert. Também nesse caso, o grupo de atores pontua com maior frequência níveis mais baixos de naturalidade (13,3\% indicou 1 e 20,4\% 2), de modo que se evidencia um menor grau de concordância entre os avaliadores. Mesmo assim, somando a pontuação nos níveis 4 e 5 , chega-se a $48 \%$ dos resultados e, acrescentando também a pontuação 3, a 66,3\%. Quanto aos "não atores", apenas a pontuação 4 e 5 representa 52,1\% das respostas. Se unirmos a essas porcentagens também o nível 3, vemos que 74,2\% dos informantes atribuíram uma avaliação de média a muito elevada para esse parâmetro.

Observando a parte aberta do questionário para compreender melhor os motivos que levaram a atribuir essas pontuações, constata-se que tanto atores quanto "não atores" se basearam efetivamente na fala para conferir as pontuações, que, muitas vezes, colocaram em relação com as ações realizadas. Os exemplos a seguir, escritos para justificar a pontuação atribuída, deixam isso claro. 
O fato de que o que vi e ouvi foi perto de uma situação real.

[Il fatto che quanto vedevo e sentivo fosse vicino ad una situazione reale.] (inf. 20, "não ator")

A espontaneidade dos diálogos me levou a atribuir as pontuações.

[La spontaneità dei dialoghi mi ha guidato ad assegnare i punteggi.] (inf. 24, "não ator")

A escolha do dialeto, a consistência do que é dito em relação à situação.

[La scelta del dialetto, la coerenza di ciò che viene detto rispetto alla situazione.] (inf. 31, ator)

A verossimilhança, a escolha das palavras, a espontaneidade e a possível presença de falas previsíveis (...). O uso de algumas expressões e termos, e uma maior espontaneidade na voz.

[La verosimiglianza, la scelta delle parole, la spontaneità e l'eventuale presenza di battute "telefonate" (...). L'uso di alcune espressioni e termini, e una maggiore spontaneità nella voce.] (inf. 42 , ator)

Note-se que tanto para os "não atores" quanto para os atores a língua e a escolha do que dizer e como são elementos importantes e podem interferir na maneira como a cena em geral é percebida e se o efeito que provoca é mais ou menos natural e verossímil. Além disso, como deixaram claro os próprios avaliadores, esse parâmetro está relacionado a outros componentes da encenação, entre os quais ação e espontaneidade, e, por isso, ainda que ação ou espaço sejam naturais, se a fala apresentasse traços inverossímeis, isso poderia afetar a percepção da naturalidade dos outros componentes e a naturalidade geral do vídeo.

Observar o gráfico que compara as médias dos dois grupos em relação à naturalidade percebida na língua utilizada nos RPs (Gráfico 23) pode oferecer mais dados para a reflexão. 
Gráfico 23 - médias língua - naturalidade "não atores" e atores

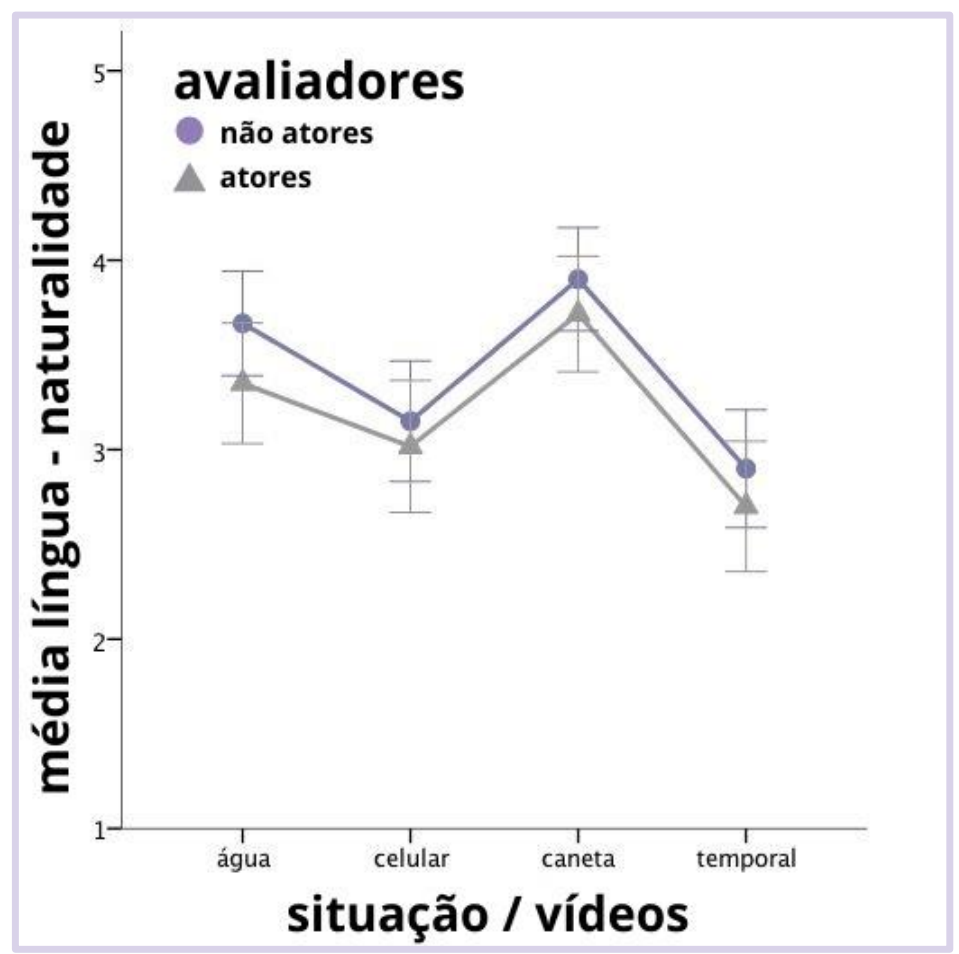

Mais uma vez, é evidente a semelhança com a qual os dois grupos analisam o parâmetro, pois, ainda que os atores apresentem quase sempre médias levemente mais baixas, não há diferença estatisticamente significante entre elas (v. tabela 5). Outra similaridade que se repete na avaliação de "não atores" e atores é a divisão entre situações de alto grau de imposição (“celular" e "temporal"), sendo a língua nesses RPs percebida como menos natural, enquanto a língua utilizada em situações de baixo grau de imposição ("água" e "caneta”) leva a atribuir pontuações mais elevadas. Confirma-se, portanto, a relevância da situação e sua influência no modo como se constitui o RP e na percepção geral de naturalidade.

Nas entrevistas com os falantes que gravaram os RPs, também encontramos afirmações sobre as escolhas linguísticas. Os participantes confirmam a naturalidade e a presença de elementos reais em suas falas. Em estudos como os de Bataller \& Shively (2011) ou de FélixBrasdefer (2018), que compararam dados naturalísticos e dados eliciados por meio de RPs, os resultados, embora também apontem diferenças, não negam a presença de similaridades, que, no entanto, são certamente mais evidentes na nossa pesquisa. De fato, quando perguntados sobre se consideravam sua fala natural, todos os participantes responderam afirmativamente. Vejamos, por exemplo, as respostas de G e P: 
G: $\operatorname{sim}$... sim, é muito real e muito próximo (...) efetivamente, o que eu disse e fiz no vídeo é o que normalmente faço na realidade.

[G: sì... sì, è molto reale e molto vicino (...) in effetti, quello che ho detto e ho fatto nel video è quello che normalmente faccio realmente.]

P: Sim, eu diria que sim, eu faria isso de novo da mesma maneira (...) totalmente natural $\operatorname{sim}($...) sim... são palavras... são palavras que com certeza uso no cotidiano e me parecem também adequadas ao contexto, àquele momento específico, à situação... ao evento (...).

[P: Sì, direi di sì, lo rifarei in questo modo (...) completamente naturale... naturale sì (...) sì... sono parole... sono parole che uso assolutamente nel quotidiano e mi sembrano anche adatte al contesto, a quel momento particolare, alla situazione... all'evento... (...).]

Na última resposta, comentando a naturalidade, $\mathrm{P}$ inclui também referências ao contexto e à adequação das palavras utilizadas à situação proposta. A esse aspecto específico é dedicado o parâmetro que denominamos de adequação da língua, para o qual os dois grupos de julgadores deram a seguinte avaliação (Gráficos 24 e 25):

Gráfico 24 - língua - adequação "não atores”

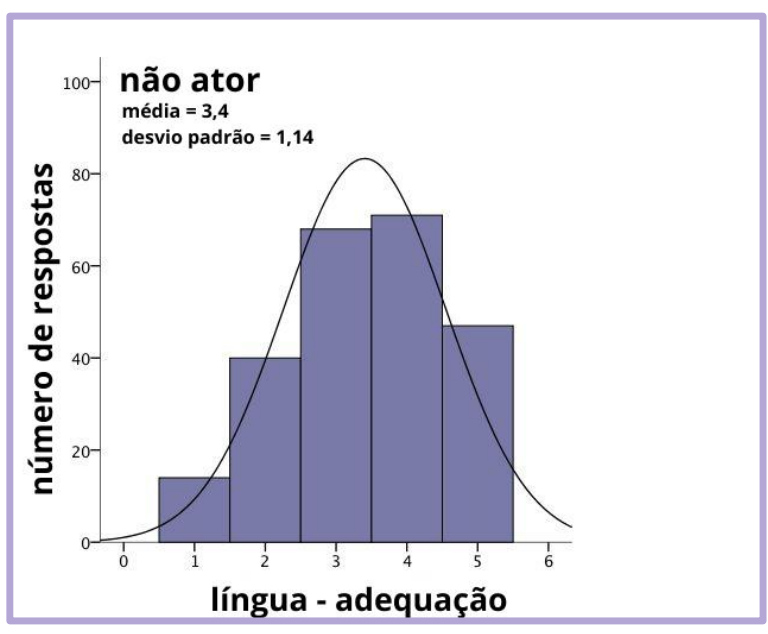

Gráfico 25 - língua - adequação atores

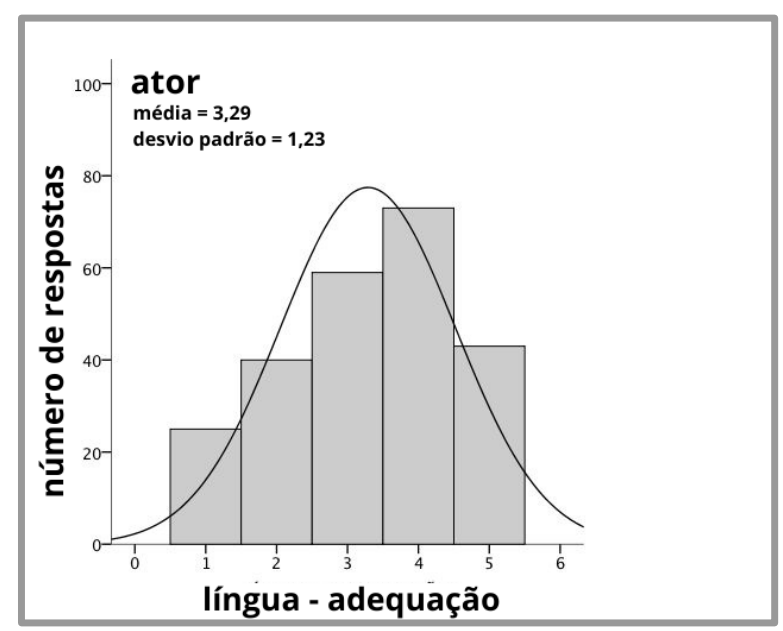

Percebe-se que, também desta vez, os dois grupos concentram a maior frequência de respostas no nível 4 (atores 30,4\%, "não atores" 29,6\%) e no nível 3 (atores 24,6\%, "não atores" $28,3 \%$ ), evidenciando assim que consideraram as escolhas linguísticas adequadas ou muito adequadas ao contexto. Também nesta avaliação, o número de atores que selecionaram a opção 1, por julgarem a fala dos RPs inadequada à situação, supera muito o de "não atores" (atores 10,4\%, "não atores" 5,8\%). Há, portanto, um grau menor de concordância entre os atores do 
que entre os "não atores", que, justificando essas respostas, apontam como critério utilizado não apenas a adequação à situação, mas também a presença do que consideram ser a "língua real", como no exemplo a seguir:

Uso de gírias, gestos e linguagem corporal (...) Maior aderência a uma linguagem real (e talvez também de gírias) nos gestos e palavras utilizadas.

[Uso di espressioni gergali, della gestualità e del linguaggio del corpo (...) Maggiore aderenza ad un linguaggio reale (e magari anche gergale) nei gesti e nelle parole usate.] (inf. 23 "não ator")

Afirmações como essa mostram que o falante "comum" baseia sua percepção da adequação de determinados elementos ao que já viu e/ou viveu em outros contextos, confirmando que todos os indivíduos não são apenas capazes de julgar o que é ou não adequado em uma interação, mas que, de fato, o fazem (HYMES, 1964).

No gráfico 26, que inclui as médias atribuídas a esses parâmetros pelos dois grupos de avaliadores, diferenciando por situação, pode-se observar comparativamente em que medida foram consideradas adequadas as escolhas linguísticas presentes no RPs.

Gráfico 26 - médias língua - adequação "não atores" e atores

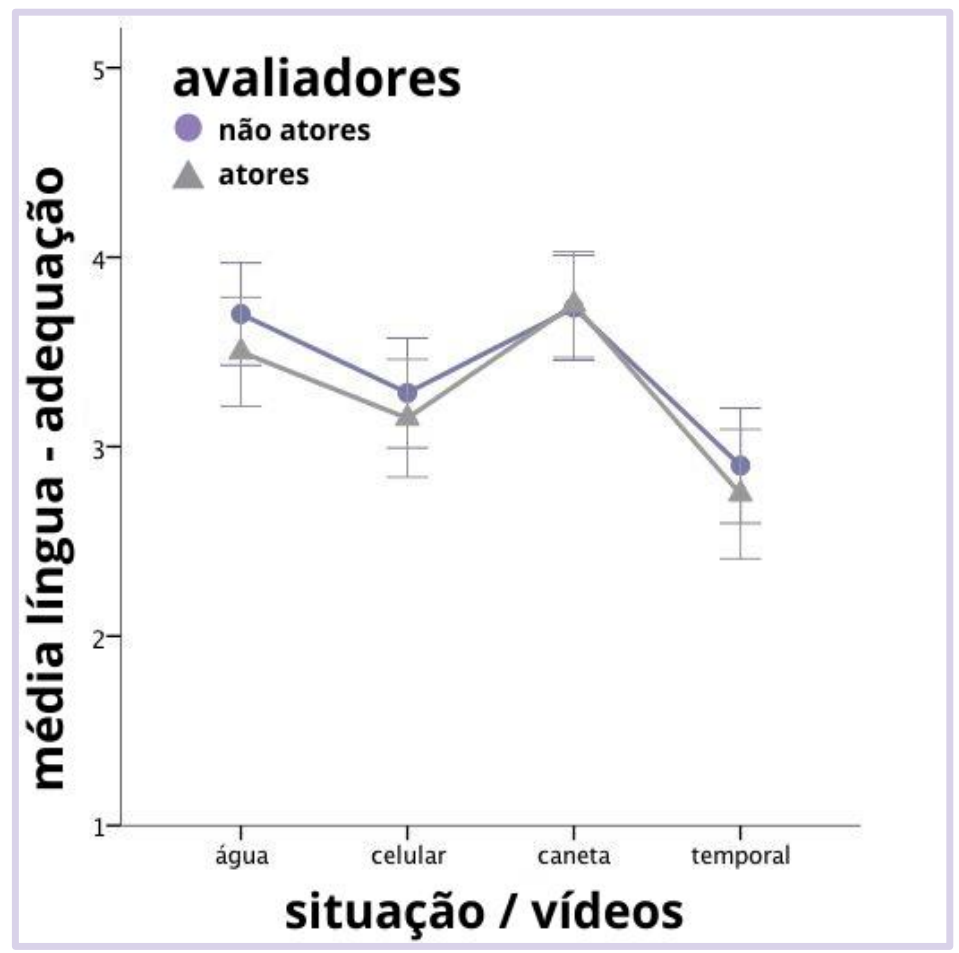

O gráfico evidencia a semelhança entre a percepção da adequação da língua por parte 
de "não atores" e atores em todas as situações, com uma coincidência quase absoluta das médias na situação "caneta" (atores 3,75; "não atores" 3,73), e também que para ambos os grupos a situação "temporal" (GI+) é aquela em que as escolhas linguísticas são julgadas menos adequadas. À língua utilizada nas situações “água” e "caneta” (GI-) é atribuída uma avaliação média geral pouco abaixo de 4 , o que indica que foi considerada muito adequada. De certo modo, isso se contrapõe à percepção da língua na situação "temporal” (GI+) e aponta, mais uma vez, para a importância do tipo de contexto, além de confirmar a força da variável grau de imposição também na avaliação da língua usada nos RPs.

Os relatos dos falantes nativos que "atuaram" no RPs confirmam a avaliação quantitativa e identificam no grau de imposição - isto é, na maior "dificuldade" da situação um fator que influenciou o modo como decidiram fazer o pedido (BROWN \& LEVINSON, 1987).

$\mathrm{N}$ : bom ... eu realmente falei livremente e disse ... realmente usei as palavras que usaria em uma situação semelhante ... a única coisa que me saltou aos olhos, ou melhor, aos ouvidos é que eu não fiz um pedido explícito para que o interlocutor me desse o celular (...) mas no resto as minhas palavras eram muito ... quer dizer .... eram dirigidas ... para mim era importante que o outro entendesse que eu não queria nad- ... ou seja ... que eu estava realmente em uma situação de necessidade, era importante que ele entendesse que eu não era alguém que pedia dinheiro ou queria roubar alguma coisa ... ou algo do tipo, não? Então era muito importante me colocar, tanto como pessoa, como também com palavras... quero dizer ... com um pedido feito de forma gentil, mas também de forma direta, digamos ... sobre o pedido que eu estava fazendo.

[N: mah... io ho parlato veramente a ruota libera e ho detto... ho usato veramente le parole che userei in una situazione simile... l'unica cosa che mi è saltata all'occhio, o meglio all'orecchio è che io non ho fatto una richiesta esplicita di avere il cellulare dell'interlocutore (... ) però per il resto le mie parole sono state molto... cioè.... erano volte... per me era importante che l'altra persona capisse che non volevo nien-...cioè... che ero veramente in una situazione di bisogno, era importante che capisse che non ero una che stava chiedendo soldi o che voleva fregare qualche cosa... o cosa del genere no? Quindi era molto importante pormi, sia come persona, e anche a parole dico... con una richiesta fatta in un modo gentile, peró anche in modo diretto, diciamo... della richiesta che stavo facendo.]

As reflexões deixam clara a consciência de $\mathrm{N}$ quanto à necessidade de adequar o nível de "gentileza" à dificuldade da situação, pensando no que e em como dizer para não dar uma imagem "errada" de si ao interlocutor. Suas considerações mostram, ainda, que esse tipo de consciência, que podemos chamar (meta)pragmática (CAFFI, 2009), foi empregada no RP, mas é algo feito evidentemente também na vida, pois o comportamento e a língua da encenação foram construídos a partir do mesmo tipo de raciocínio que a participante teria na realidade. Mais um ponto que parece contradizer a crítica sustentada por muitos linguistas. 
Além da relação que se estabelece entre língua e situação, a escolha do que dizer depende ainda do interlocutor, outro elemento explicitado na fala dos participantes:

P: (...) eu disse ... com um estranho eu teria ... eu teria me comportado de modo diferente e teria dito coisas diferentes, obviamente.

[P: (...) dicevo... con uno sconosciuto mi sarei... mi sarei comportata diversamente e avrei detto delle cose diverse, ovviamente]

$\mathrm{N}$ : (...) talvez dois dias depois eu teria escolhido duas palavras diferentes ou ... sei lá ... se em vez de um homem tivesse sido uma mulher, não posso excluir que algo teria sido diferente ... mas não... nada fundamental.

[N: (...) magari due giorni dopo avrei scelto due parole diverse o... che ne so... se invece che un uomo fosse stata una donna, non posso escludere che qualche cosa sarebbe stato diverso... ma no... niente di fondamentale.]

As entrevistas confirmam, portanto, a importância de adequar a fala não só à situação, mas também ao interlocutor, assim como indicado na literatura (GOFFMAN, 1975 [1959]; HYMES, 1972), e revelam, em mais um aspecto, que as escolhas pragmáticas são conscientes e que os falantes são capazes de reconhecê-las e de definir por quais elementos são causadas.

A presença desse tipo de consciência e o reconhecimento dos aspectos do contexto que definem o que pode ser adequado ou não a uma situação e a um interlocutor são claros indícios de que é a partir desses elementos que o falante de uma determinada língua e cultura escolhe como agir, também linguisticamente, e avalia, inclusive, os outros.

Tanto a percepção dos dois grupos de falantes nativos sobre a língua utilizada no RPs, quanto as opiniões sobre si mesmos expressas pelos quatro participantes apontam na direção de considerar naturais e adequadas as escolhas linguísticas em análise. Essas avaliações vão na direção oposta do que defende uma parte dos linguistas, considerando a língua eliciada por meio de RPs como um material sem a naturalidade e a verossimilhança necessárias para pesquisas (GOLATO, 2003).

\subsection{Role plays de atores e de "não atores": uma comparação}

Uma das características dos RPs utilizados nesta pesquisa é que foram encenados por atores e "não atores". Nesta última parte da análise, os RPs de "não atores" (PK e NG) foram 
separados daqueles de atores (LM e VE), com o objetivo de verificar se e em quais aspectos se diferenciam e se há características das duplas que emergem na avaliação.

Lembramos que cada dupla participou de dois RPs diferentes, um com uma situação de alto grau de imposição (GI+) e outro com uma situação de baixo grau de imposição (GI-). Essas divisões são recapituladas no quadro a seguir (Quadro 8).

Quadro 8 - "não atores" e atores

\begin{tabular}{|l|l|}
\hline Duplas & Vídeos / Situações \\
\hline PK -"não atores" & V1 água (GI -) / V7 temporal (GI+) \\
\hline VE - atores & V2 água (GI -) / V8 temporal (GI+) \\
\hline NG - "não atores" & V4 caneta (GI -) / V5 celular (GI+) \\
\hline VE - atores & V3 caneta (GI-) / V6 celular (GI+) \\
\hline
\end{tabular}

Vejamos a primeira comparação dos RPs encenados por "não atores" e atores. Os gráficos 27 e 28 ilustram a percepção dos dois grupos de avaliadores ("não atores" e atores) para os dois primeiros parâmetros verificados no questionário: espontaneidade e verossimilhança.

Gráfico 27 - espontaneidade (encenação de "não atores" e de atores)

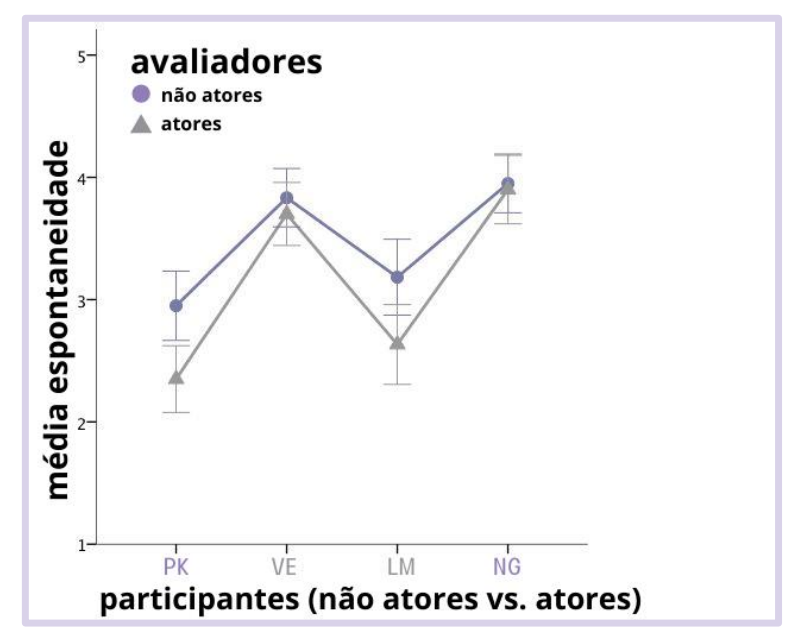

Gráfico 28 - verossimilhança (encenação de "não atores" e de atores)

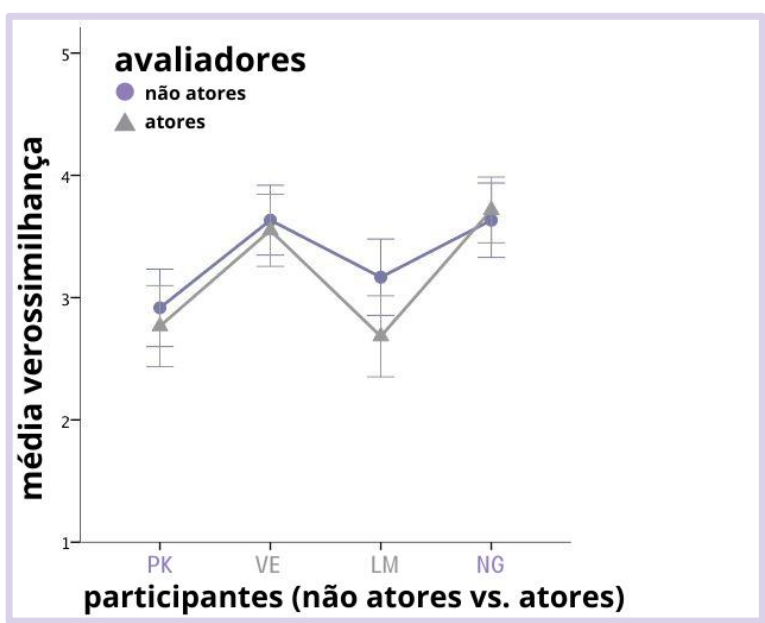

Observando os dois gráficos, a primeira informação evidente é a concordância entre as avaliações dos dois grupos: as duplas VE (atores) e NG ("não atores") são avaliadas de forma quase idêntica nos dois parâmetros e na verossimilhança a coincidência na avaliação diz 
respeito também à dupla PK (“não atrizes”). No critério da espontaneidade, a mesma dupla recebeu uma pontuação diferente pelos avaliadores: enquanto o grupo de avaliadores atores indicou espontaneidade abaixo da média para essa dupla (média: 2,35), os "não atores" indicaram um nível médio de espontaneidade (média: 2,95). Os gráficos mostram diferenças nas avaliações dos dois grupos também para a dupla LM (atores) em ambos os parâmetros: atores consideraram tanto a espontaneidade (média: 2,63) quanto a verossimilhança (média: 2,68) dessa dupla como inferiores à média, enquanto "não atores" atribuíram uma pontuação acima de 3 (médias: 3,18 / 3,17). Com exceção da primeira dupla, todas as outras apresentam média entre 3 e 4, indicando uma avaliação entre intermediária e e elevada nesses parâmetros.

Outra informação mostrada pelos gráficos é que as duplas que recebem avaliações mais altas para espontaneidade e verossimilhança são uma dupla de atores (VE) e uma dupla de "não atores" (NG), sendo a dupla composta por "não atores" a mais bem avaliada nos dois parâmetros. As pontuações confirmariam tanto as ideias de Goffman (1975 [1959]) quanto o que é evidenciado no trabalho de Boal (2015): mesmo não atores são capazes de encenar o cotidiano e de transferir para a gravação de uma situação "encomendada" suas experiências de vida. Além disso, uma vez que a dupla mais bem avaliada é composta por "não atores", ou seja, pessoas que não possuem nenhuma familiaridade com representações profissionais, a verossimilhança e a espontaneidade percebidas em suas encenações se daria pelo fato de estarem representando nos RP o que encenam também na vida real.

Passando agora para a categoria "espaço", temos os seguintes gráficos (Gráficos 29 e $30)$.

Gráfico 29 - espaço - naturalidade (encenação de "não atores" e de atores)

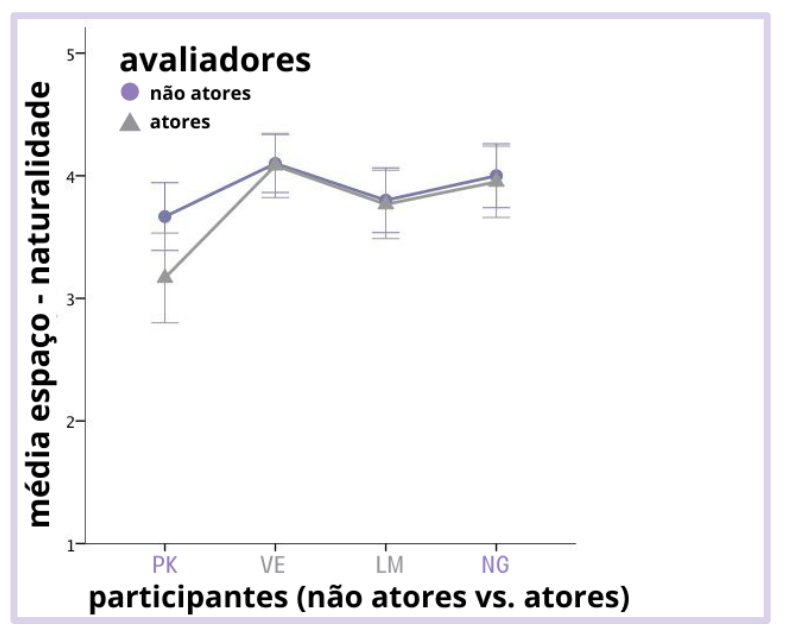

Gráfico 30 - espaço - adequação (encenação de "não atores" e de atores)

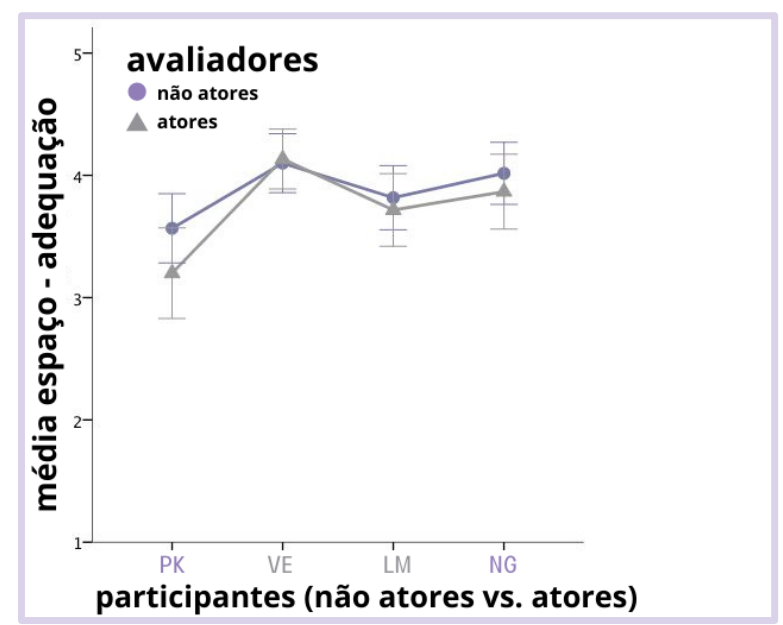

Vê-se que não só não há diferença significante entre a avaliação de "não atores" e atores 
para esses parâmetros, mas também a naturalidade do espaço é percebida de maneira muito similar tanto por atores quanto por "não atores", com exceção daquele em que encenou a primeira dupla (PK). Aliás, embora a primeira dupla tenha recebido uma média mais baixa, tanto do grupo dos "não atores" quanto do grupo dos atores, todas as avaliações são superiores ao valor médio da escala Likert (3).

Tendo em vista que o espaço é algo independente de quem atua (GOFFMAN, 1975 [1959]), era de se esperar que nesses critérios as duplas recebessem avaliações semelhantes. Ao contrário, ações e escolhas linguísticas dependem diretamente dos sujeitos. Portanto, a avaliação dos próximos dois critérios pode fornecer indícios interessantes. Começaremos pela ação nos dois gráficos seguintes (Gráficos 31 e 32).

Gráfico 31 - ação - naturalidade (encenação de "não atores" e de atores)

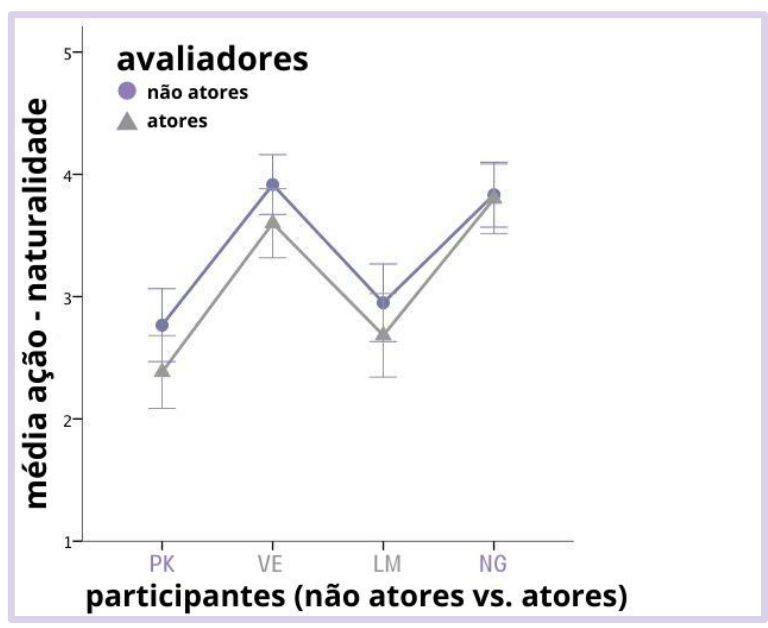

Gráfico 32 - ação - adequação (encenação de "não atores" e de atores)

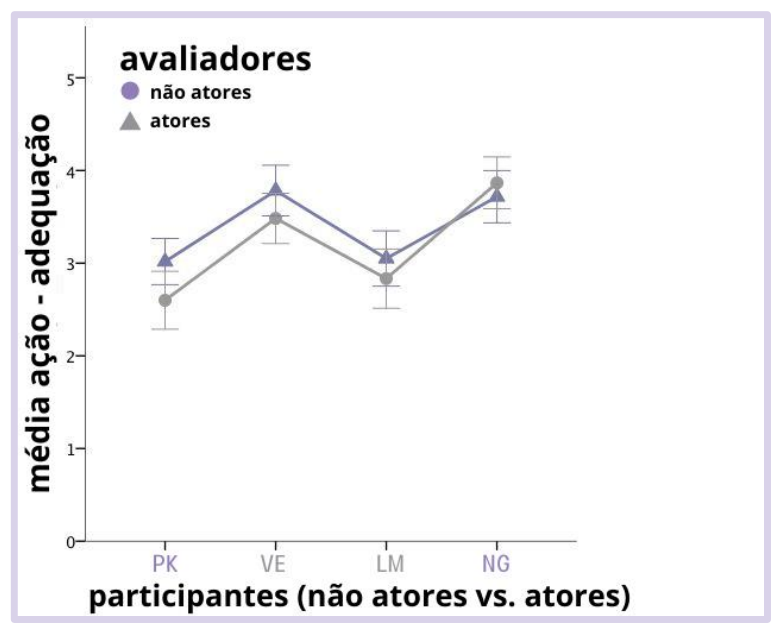

A tendência é parecida àquela que se constatou na pontuação da espontaneidade e da verossimilhança com as ações de duas das duplas, uma composta por "não atores" (NG) e uma composta por atores (VE), que são percebidas como muito naturais (todas as médias ficaram pouco abaixo do nível 4 da escala Likert). Já as ações das outras duas duplas (PK “não atrizes" e LM atores) apresentaram avaliações um pouco abaixo da média, indicando mais uma vez que a percepção da naturalidade nesses RPs não está relacionada ao fato de os participantes serem ou não atores. No que diz respeito à adequação das ações à situação, o gráfico 32 também mostra avaliações em torno da média (nível 3 da escala Likert), nesse caso, com o grupo de atores considerando um pouco abaixo da média a adequação das ações das duplas PK ("não atrizes") e "LM" (atores). Note-se ainda que no que diz respeito às ações da dupla NG ("não atores") as avaliações dos grupos "não atores" e atores se inverte, com os atores concedendo uma média levemente mais alta para essa dupla em relação ao grupo dos "não atores". 
Uma vez que tanto a dupla que recebeu a menor avaliação (PK), quanto a que recebeu a avaliação mais alta (NG) compostas por "não atores", e que ambas encenaram uma situação de alto grau de imposição (“celular” - NG; "temporal” - PK) e outra de baixo grau de imposição (“caneta" - NG; “água” - PK), a percepção da naturalidade por parte dos dois grupos de avaliadores não pode ser considerada relacionada ao grau de imposição.

Por fim, vejamos como foram avaliadas "as palavras e as expressões" escolhidas pelas duplas (Gráficos 33 e 34), tanto do ponto de vista da naturalidade, quanto considerando a adequação à situação.

Gráfico 33 - língua - naturalidade (encenação de "não atores" e de atores)

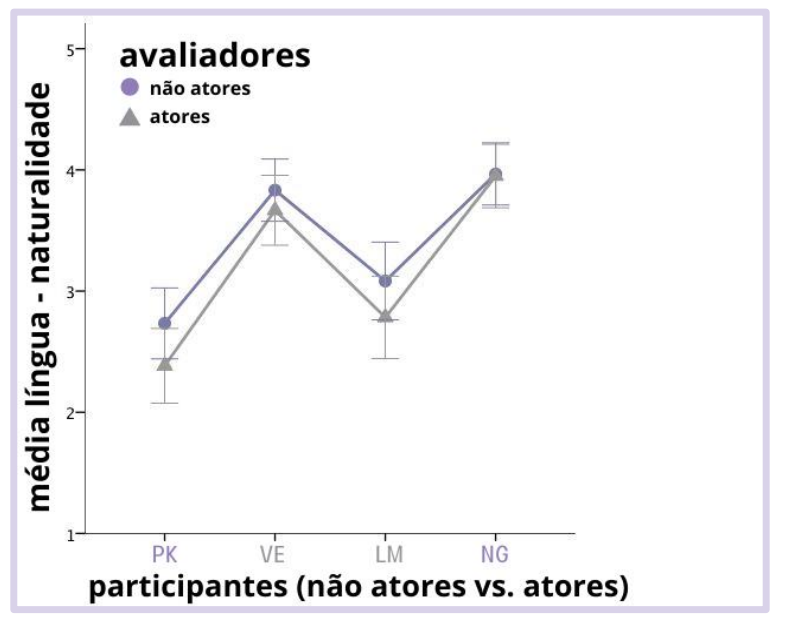

Gráfico 34 - língua - adequação (encenação de "não atores" e de atores)

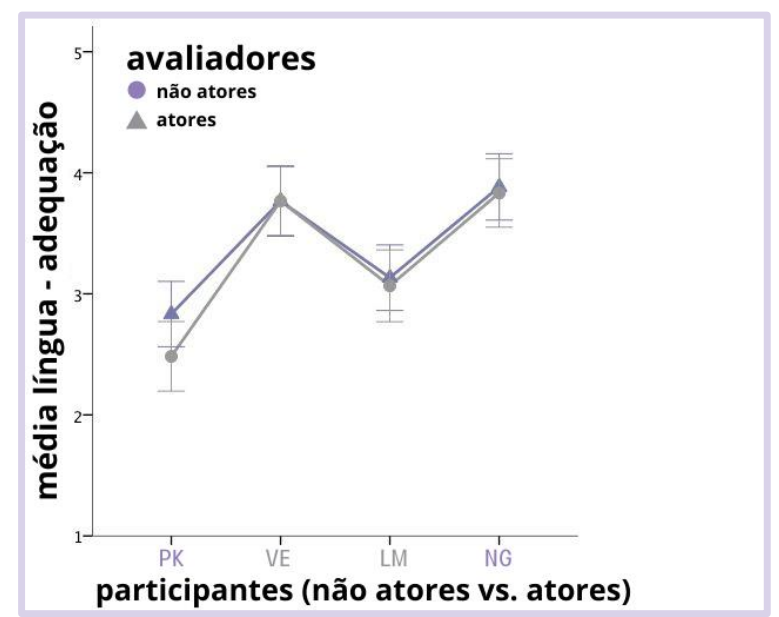

Fica evidente que as avaliações dos dois grupos mantêm também nesse caso o mesmo "andamento", embora em alguns casos as pontuações sejam perfeitamente coincidentes e em outros casos levemente diferentes. De qualquer maneira, também na avaliação das escolhas linguísticas, a dupla de "não atores" NG e a dupla de atores VE são percebidas como mais naturais e também mais adequadas à situação em relação às outras duplas.

Já no que diz respeito às duplas PK ("não atores") e LM (atores), embora não haja diferença estatística significante, os dois grupos de avaliadores ("não atores" e atores) apresentaram um menor nível de concordância em relação à naturalidade da língua produzida, com o grupo de atores atribuindo uma pontuação média abaixo do 3, enquanto o grupo de "não atores" definiu para a naturalidade da língua um nível médio um pouco maior. Na avaliação da adequação da língua à situação, as pontuações dessas duas duplas são muito semelhantes às da naturalidade, embora haja uma maior coincidência na dupla LM.

Em primeiro lugar, o que essas análises mostram é que a língua dos participantes, tanto atores quanto "não atores", apresenta um nível médio/médio-alto de naturalidade e de 
adequação na visão dos falantes nativos. Além disso, é interessante observar que as escolhas linguísticas dos "não atores" nos RPs podem apresentar um alto nível de naturalidade e de adequação à situação, tanto na visão dos dois grupos de falantes nativos ("não atores" e atores) quanto na visão do próprio participante que, segundo Pallotti (2001) e também segundo Goffman (1975 [1959]), seria aquele que possui maior propriedade para falar das escolhas feitas na interação.

Lembrando que os avaliadores não sabiam quais RPs haviam sido gravados por atores e quais por "não atores", concluímos com as observações feitas por dois atores a respeito das diferenças que acreditaram ter encontrado:

Na minha opinião, via-se como as pessoas comuns, mesmo ganhando algo em espontaneidade, não tinham muita consideração do espaço e eram mais "desajeitadas" tanto na atuação quanto na técnica como dicção e articulação das falas.

[A mio parere si vedeva come le persone comuni, pur guadagnando qualcosa in spontaneità non avessero ben contezza dello spazio e fossero più "impacciate" nella recitazione oltre che nella tecnica come dizione e articolazione delle battute.] (inf. 54, ator)

\begin{abstract}
'Pessoas comuns' são mais espontâneas e críveis, mesmo que cometam "erros" como sobrepor sua fala a do outro e desconsiderar a câmera (há uma participante cujo rosto nunca se vê). Elas também têm pressa para terminar, enquanto os atores alongam a cena até mais do que o necessário, como se quisessem ocupar mais espaço do que a cena exige.

[Le "persone comuni" sono più spontanee e credibili anche se commettono "errori" come accavallarsi quando parlano e non considerare la telecamera (c'è una partecipante a cui non si vede mai la faccia). Hanno anche fretta di finire, mentre gli attori allungano la scena anche più del necessario come se volessero occupare più spazio di quello che la scena richiede.] (inf. 46, ator)
\end{abstract}

Com a evidente semelhança entre os RPs de "não atores" e atores mostrada nas análises, podemos reafirmar o que já dissemos, isto é, que também "não atores" são capazes de representar com naturalidade, pois empregam nos RPs traços e comportamentos que são parte de suas ações cotidianas reais. Por essa mesma razão, movimentos teatrais atuais como o do grupo Rimini Protokoll (§ 1.4) conseguem colocar em cena parcelas significativas de realidade, partindo da participação de "não atores".

Pelas avaliações que vimos nessa seção, é evidente que os avaliadores, mesmo quando acreditam distinguir quem é ator de quem não o é, de fato, não reconhecem claras diferenças. Para confirmar isso, incluímos no questionário uma pergunta final, na qual se pedia para 
identificar quais vídeos haviam sido gravados por atores e quais por não atores. A maioria dos informantes dos dois grupos identificou como duplas de atores VE (47 votos), que, de fato, era formada por atores, mas também NG (42 votos), que, ao contrário, era uma dupla de "não atores". Parece mesmo que Boal tinha razão: somos todos espect-atores. 


\section{Considerações finais}

A pesquisa buscou compreender se e em que medida o role play (RP), metodologia amplamente utilizada na coleta de dados para estudos sobre a língua em uso, é eficaz para eliciar amostras que possam mostrar como os falantes se comunicam na "realidade". Utilizamos como exemplo para o nosso estudo e as nossas análises RPs em língua italiana em que eram realizados pedidos, gravados em duplas por falantes nativos (atores e "não atores").

Para esse fim, partiu-se do questionamento levantado por alguns linguistas (cf. GOLATO, 2003), os quais defendem que, sendo uma representação, o RP e o material eliciado por meio dele, seriam distantes da realidade, não podendo ser considerados adequados para a observação de fenômenos linguísticos. Para verificar essa questão, a representação foi observada à luz de um referencial teórico composto por obras provenientes de várias áreas do conhecimento, dentre as quais, as teorias do teatro, a performance, os estudos linguísticos e sociolinguísticos e principalmente a perspectiva sociológica de Goffman (1975 [1959]). Além disso, os RPs gravados com italianos "não atores" e atores foram avaliados por dois grupos de falantes nativos (também “não atores” e atores), a partir de oito parâmetros pré-selecionados com base na literatura de referência e identificados aqui como constituintes de interações humanas que podem ocorrer na vida, no teatro e também nos RPs. Esses parâmetros são: a espontaneidade, a verossimilhança da situação, a naturalidade e a adequação do espaço, a naturalidade e a adequação da ação, a naturalidade da língua e a adequação da língua.

A pontuação das avaliações foi obtida por meio de questionários online (com uma escala Likert, que previa uma pontuação de 1 a 5 , sendo 1 o valor mais baixo e 5 o mais alto) e analisada a partir de testes estatísticos que verificaram, em primeiro lugar, a eficácia do instrumento, ou seja, o próprio questionário. Após identificar que o instrumento era capaz de aferir a percepção da naturalidade de RPs, apresentando uma confiabilidade de 93,8 \%, com o software SPSS foram realizados testes $G L M$, que nos permitiram responder às três perguntas que guiaram o estudo. A primeira pergunta era:

De que forma os falantes nativos de italiano avaliam a naturalidade e a adequação de RPs gravados em áudio e vídeo, em língua italiana, tendo em vista o contexto situacional proposto e utilizando categorias pré-definidas? 
Os resultados das análises indicaram que a maioria dos RPs selecionados para o estudo foram percebidos pelos dois grupos de avaliadores ("não atores" e atores) como naturais e verossímeis ou, em alguns casos, muito naturais e muito verossímeis, com exceção do vídeo 7 (gravado com "não atores") que foi considerado tanto por "não atores" quanto por atores como “pouco verossímil”, obtendo uma pontuação geral abaixo do valor médio 3 indicado na escala Likert.

Já a análise geral de cada parâmetro ou categoria pré-definida, na qual foram considerados todos os vídeos, os valores médios foram sempre superiores ao valor intermediário 3 da nossa escala, indicando que foi percebida uma correspondência entre cada um dos elementos observados no teste e o que os avaliadores consideram parte de sua realidade, atribuindo ao que foi julgado características de espontaneidade, verossimilhança, naturalidade e adequação.

A segunda pergunta que guiou o nosso estudo foi:

Em que medida varia ou converge e quais aspectos evidencia a forma como falantes nativos atores e "não atores" percebem a naturalidade e/ou a adequação de uma seleção de RPs e de elementos que os constituem?

Em resposta a essa pergunta, verificou-se que, apesar de os dois grupos de avaliadores ("não atores" e atores) apresentarem médias diferentes na avaliação de cada um dos parâmetros, e de o grupo de "não atores", em geral, atribuir pontuações mais elevadas que o grupo dos atores, as avaliações apresentaram mais convergências que divergências. Esse fato foi identificado por meio da comparação entre as médias dos dois grupos, observadas por parâmetro e por situação, com resultados que evidenciam que há diferença significante entre as avaliações apenas na espontaneidade da situação que chamamos "temporal" $(p=0,35)$ e na adequação da ação encenada na situação dita "água" ( $p=0,32)$. Os testes mostraram ainda que, tanto na análise geral dos vídeos quanto nas específicas (divididas por parâmetros e situações), os dois grupos se comportaram de maneira semelhante, apresentando concordância em relação à percepção da naturalidade dos RPs.

Buscando fazer convergir a perspectiva ética ou externa, acessada por meio dos questionários e das avaliações quantitativas dos falantes, e a visão dos próprios participantes (perspectiva êmica ou interna), para uma reflexão mais aprofundada do nosso objeto de estudo (KÁDÁR \& HAUGH, 2013), a terceira pergunta que serviu de base para o estudo foi: 
De que maneira os participantes dos RPs percebem e avaliam seu comportamento, ou seja, suas próprias representações, e como descrevem, partindo das mesmas categorias utilizadas para os falantes nativos, a experiência de ter realizado as gravações, comparada, inclusive, com sua vida real?

Para responder a essa pergunta, os RPs dos falantes nativos "não atores" foram submetidos à avaliação dos próprios indivíduos participantes, os quais, por meio de entrevistas retrospectivas, julgaram suas encenações a partir dos mesmos parâmetros propostos nas escalas, ou seja, aqueles que compunham o questionário. Todos os participantes avaliaram as ações e as escolhas linguísticas que fizeram no momento da realização dos RPs como "muito naturais" e "muito adequadas", indicando ainda que em situações reais se comportariam da mesma maneira. Essas considerações vão na direção contrária à crítica de parte dos linguistas, segundo a qual os RPs produziriam amostras linguísticas inverossímeis e artificiais. Também por meio das entrevistas foi possível saber que, de acordo com os participantes, algo que foi feito ou que foi dito na cena poderia ocorrer de maneira diferente, não por causa da situação ou da filmagem, mas principalmente considerando o interlocutor: falar com uma mulher ou com um homem ou falar com uma pessoa mais próxima ou mais distante poderia causar diferenças na realização de um ato de fala como o pedido. É possível afirmar que essas considerações evidenciam, em primeiro lugar, a consciência (meta)pragmática dos entrevistados (CAFFI, 2009). Além disso, as falas dos entrevistados mostram não só que RPs são capazes de eliciar dados que correspondem à realidade do falante, mas também a importância do papel desenvolvido pelo interlocutor nas escolhas feitas pelos indivíduos, no momento de qualquer interação (GOFFMAN, 1975[1959]; HYMES, 1972).

Corroborando a percepção dos participantes e também a convergência entre essas avaliações e o julgamento dos dois grupos ("não atores" e atores), um teste feito comparando os RPs realizados por "não atores" com aqueles realizados por atores confirmou a dificuldade de diferenciar entre as duplas e, portanto, que parece haver características comuns a todos os seres humanos. Confirmou-se que a falta de familiaridade com a câmera e/ou com o cotidiano da atuação não interferiu na naturalidade que os "não atores" empregaram nas representações e que foi percebida também pelos avaliadores. Na avaliação dos vídeos por duplas, considerando todos os parâmetros, a dupla NG ("não atores") foi a mais bem avaliada, seguida, então, da dupla VE (atores). 


\section{- Limitações e dificuldades da pesquisa}

Tendo em vista que o presente estudo é experimental e exploratório, a maior dificuldade encontrada durante o percurso foi a de colocar em diálogo áreas tão amplas e complexas, a fim de seguir a proposta inicial e tentar discutir, a partir de múltiplas perspectivas, um tema que é naturalmente interdisciplinar. Escolher os termos adequados para manter a clareza e, ao mesmo tempo, buscar criar um debate em que houvesse intersecção de ideias e cooperação entre os pontos de vista dos vários autores e áreas foi, sem dúvida, um grande desafio.

Também por ser um estudo experimental, o trabalho apresenta algumas limitações. Uma delas é o número de informantes que, embora suficiente para a realização dos testes estatísticos, ainda é limitado para que se possam generalizar os resultados obtidos ao comportamento ou à percepção da naturalidade e da adequação de RPs por parte da população (nesse caso, a italiana). Outra limitação presente na pesquisa é a quantidade de vídeos analisados que está relacionada e influenciou diretamente o número limitado de respondentes das entrevistas. Como dissemos, apenas os participantes "não atores" foram entrevistados e, portanto, a perspectiva êmica foi obtida por meio de entrevistas com apenas quatro informantes.

Existem, portanto, limitações no estudo, mas, considerando que os testes mostraram um bom resultado na avaliação do questionário e que a combinação de instrumentos (questionários e entrevistas) e de perspectivas oferece uma análise mais ampla dos RPs, o presente trabalho pode colaborar com o debate sobre a naturalidade e a adequação dos dados eliciados por meio dessa metodologia, já utilizada em pesquisas de diversas áreas da Linguística.

Além disso, colocando em prática e em discussão a combinação de perspectivas apontada na literatura (KÁDÁR \& HAUGH, 2013), a pesquisa retoma a essência dos estudos em Pragmática, que visam a uma observação da língua, partindo do ponto de vista de quem, de fato, a utiliza.

\section{- Aplicação dos resultados da pesquisa e perspectivas futuras}

Concluída essa fase da pesquisa, pretende-se ampliar a compreensão dos resultados não só a partir de um maior número de informantes e de RPs, mas também continuando a investigar as maneiras como uma observação interdisciplinar pode contribuir para aprofundar o debate, com uma análise das interações humanas, que leve em conta o que as pessoas dizem e, sobretudo, como dizem o que dizem. 
De qualquer forma, com a investigação realizada até agora, já foi possível perceber que a valorização do material linguístico eliciado por meio de RPs pode trazer contribuições para a própria análise linguística, mas também para outras áreas como o teatro e a performance ou o ensino e a aprendizagem de línguas.

No âmbito das pesquisas linguísticas, ter constatado a presença de indícios claros de que o RP pode ser utilizado para investigar aspectos de interações verbais cotidianas pode colaborar para a compreensão mais aprofundada de sua natureza e para a realização de estudos que não seriam viáveis utilizando, por exemplo, a gravação de conversas espontâneas, porque necessitam do controle de variáveis e/ou de poder ser ampliados e replicados. 


\section{REFERENCIAS}

ANDORNO, C. Che cos'è la pragmatica linguistica. 1. ed ed. Roma: Carocci, 2005.

ANDRADE, C. "TEATRO-JORNAL" DE AUGUSTO BOAL E A DESCOBERTA DO

TEATRO DO OPRIMIDO, 2013. Disponível em: <https://www.ufrgs.br/ppgac/wpcontent/uploads/2013/09/Teatro-jornal-de-Augusto-Boal-e-a-descoberta-do-Teatro-doOprimido.pdf. > Último acesso: 05 de abril 2021.

ARRUDA, R. Realismo e Vanguardas: Uma tensão que faz mover [Rejane Arruda]. Repertório, v. 0, n. 0, p. 214-220, 2016.

AUSTIN, J. L. How to do things with words. London: Oxford University Press, 1962.

BARNI, R. Antecedentes da comédia setecentista: a Commedia dell'arte. In: R. S. JUNQUEIRA; M. G. C. MAZZI (Orgs). O teatro no século XVIII: presença de Antônio José da Silva, o Judeu. 2008. São Paulo: Perspectiva.

BATALLER, R. \& SHIVELY, R. L. Roleplays and naturalistic data in interlanguage pragmatics research: Service encounters during study abroad. Journal of Linguistics and Language Teaching, v. 2, n.1, p. 15-p. 15 - 50, 2011. Disponível em: <https://sites.google.com/site/linguisticsandlanguageteaching/home-1>.

BAZZANELLA, C. Linguistica e pragmatica del linguaggio: un'introduzione. Nuova ed. ampliata ed. Roma [etc.]: GLF editori Laterza, 2008.

BERTHOLD, M.; ZURAWSKI, M. P.; GUINSBURG, J.; COELHO, S. História mundial do teatro. São Paulo: Perspectiva, 2001.

BLUM-KULKA, S.; HOUSE, J. J.; KASPER, G.; ROEVER, C. Cross-Cultural Pragmatics: Requests and Apologies. Norwood, New Jersey: Alex Publishing Corporation, 1989.

BOAL, A. Jogos para atores e não atores. São Paulo: SESC SP e COSAC \& NAIFY, 2015. BROWN, P.; LEVINSON, S. Politeness: Some Universals in Language Use. Cambridge University Press, 1987.

CAFFI, C. Pragmatica: sei lezioni. Roma: Carocci, 2009.

CARLSON, M. A.; DINIZ, T. F. N.; PEREIRA, M. A. Performance: uma introdução crítica. Belo Horizonte: Editora UFMG, 2010.

CAVAGNA, A. DA S.; RUSCH, R. DE J. Sistema Stanislavski: a Relação entre a Psicologia, o Teatro e os Processos Psíquicos Envolvidos no Trabalho do Ator Criador, 
2019. Disponível em: 〈https://psicologado.com.br/atuacao/psicologia-social/sistemastanislavski-a-relacao-entre-a-psicologia-o-teatro-e-os-processos-psiquicos-envolvidos-notrabalho-do-ator-criador>. Acesso em: 13/8/2020.

CROOKALL, D.; OXFORD, R. L.; SAUNDERS, D. Towards a reconceptualization of simulation: From representation to reality. Simulation/Games for Learning, v.17, p. 147171, 1987.

CROOKALL, D.; SAUNDERS, D. (ORGS.). Communication and simulation: from two fields to one theme. Clevedon, Avon, England; Philadelphia: Multilingual Matters Ltd, 1989.

CRYSTAL, D. The Cambridge encyclopedia of language. 2nd ed. Cambridge; New York: Cambridge University Press, 1997.

EDMONDSON, W.; HOUSE, J.; KASPER, G.; STEMMER, B. Learning the Pragmatics of Discourse: A Project Report. Applied Linguistics, v. 5, n. 2, p. 113-127, 1984.

EISENSTEIN, M.; BODMAN, J. Expressing Gratitude in American English. In: G. Kasper e S. Blum-Kulka, (Orgs.); Interlanguage Pragmatics, p. 64-81, 1993. Oxford University Press, Cary.

FÉLIX-BRASDEFER, J. C. 12. Role plays. Methods in Pragmatics, 2018. De Gruyter Mouton. Disponível em:

<https://www.degruyter.com/view/book/9783110424928/10.1515/9783110424928-012.xml〉. Acesso em: 10/8/2020.

FÉLIX-BRASDEFER, J. C. Declining an invitation: A cross-cultural study of pragmatic strategies in American English and Latin American Spanish. Multilingua - Journal of Cross-Cultural and Interlanguage Communication, v. 22, n. 3, p. 225-255, 2003.

FÉLIX-BRASDEFER, J. C. Natural speech vs. elicited data: A comparison of natural and role play requests in Mexican Spanish. Spanish in Context, v. 4, n. 2, p. 159-185, 2007.

FIELD, A. Discovering Statistics Using IBM SPSS Statistics: And Sex and Drugs and Rock "N" Roll. 4th Edition, Sage, Los Angeles, London, New Delhi, 2013.

GARDE, U.; MUMFORD, M. Theatre of real people: diverse encounters at Berlin's Hebbel am Ufer and beyond. 2016.

GOFFMAN, E. A representação do eu na vida cotidiana. Petrópolis: Vozes, 2004.

GOFFMAN, E. Forms of talk. Philadelphia: University of Pennsylvania Press, 1981.

GOFFMAN, E. On Face-Work. Psychiatry, v. 18, n. 3, p. 213-231, 1955. 
GOFFMAN, E. Ritual de interação: ensaios sobre o comportamento face a face. Tradução de Fábio Rodrigues Ribeiro da Silva. Petrópolis, RJ: Vozes, 2011 [1967]. (Coleção Sociologia).

GOLATO, A. Naturally Ocurring Data. In: A. Barron; Y. Gu; G. Steen (Orgs.); The Routledge Handbook of Pragmatics. $1^{\circ}$ ed, p.21-26, 2017. New York, Abingdon: Routledge. Disponível em: <https://www.taylorfrancis.com/books/9781317362579>. Acesso em: $6 / 2 / 2020$.

GOLATO, A. Studying Compliment Responses: A Comparison of DCTs and Recordings of Naturally Occurring Talk. Applied Linguistics, v. 24, n. 1, p. 90-121, 2003.

GUINSBURG, J. Stanislávski e o teatro de arte de Moscou: do realismo externo ao tchekhovismo. Sao Paulo: Perspectiva, 1985.

HYMES, D. "Introduction: Toward Ethnographies of Communication.". American Anthropologist, v. 66, n. 6, p. 1-34, 1964.

HYMES, D. Foundations in sociolinguistics: an ethnographic approach. Philadelphia, Pa: Univ. of Pennsylvania Pr, 1974.

HYMES, D. Foundations in sociolinguistics: An ethnographic approach. 1974a.

Philadelphia, PA: The University of Pennsylvania Press. Hymes, D.

HYMES, D. On Communicative Competence. In J. Pride, \& J. Holmes (Orgs.); Sociolinguistics. p. 269-285, 1972. Harmondsworth: Penguin Books.

HYMES, D. The ethnography of speaking. In: B. G. Blount (Org.). Language, Culture and Society: A book of readings. p. 189 - 223, 1974 b. Cambridge, Ma: Winthrop Publishers Inc.

JUCKER, A. H. 1. Data in pragmatic research. In: A. H. Jucker; K. P. Schneider; W. Bublitz (Orgs.); Methods in Pragmatics. p.3-36, 2018. Berlin, Boston: De Gruyter. Disponível em: <http://www.degruyter.com/view/books/9783110424928/9783110424928001/9783110424928-001.xml>. Acesso em: 14/8/2020.

KÁDÁR, D. Z.; HAUGH, M. Understanding politeness. Cambridge: Cambridge University Press, 2013.

KASPER, G. Data collection in pragmatics research. In: H. Spencer-Oatey (Org). Culturally Speaking. Managing Rapport Through Talk Across Cultures. P. 316-341, 2000. London: Continuum.

KASPER, G., \& Dahl, M. Research methods in interlanguage pragmatics. Studies in Second Language Acquisition, v. 13, p. 215-247, 1991.

KASPER, G.; YOUN, S. J. Transforming instruction to activity: Roleplay in language 
assessment. Applied Linguistics Review, v. 9, n. 4, p. 589-616, 2018.

KRESS, G. Multimodality. 0 ed. Routledge, 2009.

LABAKI, A.; VÁSSINA, E. Stanislávski-Vida, Obra e Sistema. Rio de Janeiro: Funarte, 2015.

LABOV, W. The study of language in its social context. Studium Generale, v. 23, p. 30-87, 1970.

LOMBARDI VALLAURI, E. La struttura informativa: forma e funzione negli enunciati linguistici. 1a ed ed. Roma: Carocci, 2009.

MACKEY, A.; GASS, S. M. Second Language Research: Methodology and Design. $1^{\text {a }}$ edição ed. New York: Routledge, 2005.

MENDES, J. G. Teatros do real, teatros do outro: os atores do cotidiano em cena contemporânea, 31. out. 2017. Doutorado em Teoria e Prática do Teatro, São Paulo: Universidade de São Paulo. Disponível em:

$<$ http://www.teses.usp.br/teses/disponiveis/27/27156/tde-31102017-145052/>. Acesso em: $5 / 4 / 2021$.

NALIN, V. A. Os atos diretivos nas peças psicológicas de Nelson Rodrigues, 12. dez. 2016. Mestrado em Semiótica e Lingüística Geral, São Paulo: Universidade de São Paulo. Disponível em: <http://www.teses.usp.br/teses/disponiveis/8/8139/tde-12122016-122058/>. Acesso em: 5/4/2021.

NASCIMENTO SPADOTTO, L.; SANTORO, E. Ordens e pedidos em língua italiana: um estudo da percepção de falantes nativos e aprendizes brasileiros. Letrônica, v. 12, n. 4, p. 34170, 2019.

NICKELS, E. L. Interlanguage pragmatics and the effects of setting. In: K. Bardovi-Harlig; J. César Félix-Brasdefer; A. S. Omar (Orgs), Pragmatics language learning. p. 253-280, 2006. Honolulu, HI: University of Hawai'i Press.

OCHS, E. Transcription as Theory. In: E. Ochs; B. Schieffelin (Orgs.); Developmental Pragmatics. p.43-72, 1979. New York, NY: Academic Press.

PALLOTTI, G. L'ecologia del linguaggio: contestualizzazione dei dati e costruzione di teorie. In F. Albano Leoni, E. Stenta Krosbakken, R. Sornicola, C. Stromboli (Orgs.); Dati empirici e teorie linguistiche, atti del XXXIII Congresso internazionale di studi della Società di Linguistica Italiana. p. 37-57, 2001. Roma: Bulzoni.

PAVIS, P.; GUINSBURG, J.; PEREIRA, M. L. Dicionário de teatro. São Paulo: Perspectiva, 2001.

PIRANDELLO, L. L’umorismo, 2018 [1908]. 
https://www.liberliber.it/mediateca/libri/p/pirandello/l_umorismo/pdf/pirandello_1_umorismo. pdf

RINTELL, M., \& MITCHELL, C.J. Studying requests and apologies: An inquiry into method. In: BLUM-KULKA, S.; HOUSE, J. J.; KASPER, G.; ROEVER, C. (Orgs.) CrossCultural Pragmatics: Requests and Apologies. Norwood, New Jersey: Alex Publishing Corporation, p. 248-271, 1989.

RODRÍGUEZ, C.; ESTEBAN, A. De la pragmática lingüística a la pragmática teatral, 2015. Disponível em: 〈http://repositorio.uchile.cl/handle/2250/135086>. Acesso em: $5 / 4 / 2021$.

SANTORO, E. A constituição de um corpus de italiano falado para o estudo de pedidos e pedidos de desculpas: considerações sobre a validade interna e externa dos dados. In: H. Mello; M. Pettorino; T. Raso (Orgs.); Proceedings of the VII GSCP International Conference: Speech and Corpora. p.103-107, 2012. Firenze: Firenze University press.

SANTORO, E. Lo sviluppo della competenza pragmatica in italiano L2: Un esperimento a partire da un corso online. In: I. Vedder; M. Rückl; E. Santoro (Orgs.); Contesti di apprendimento di italiano L2: tra teoria e pratica didattica. Firenze: Franco Cesati, p. 2742, 2013.

SANTORO, E.; PORCELLATO, A. M. Língua, cultura e cognição: um estudo do ato de fala do pedido em italiano, português brasileiro, espanhol argentino e alemão. PERcursos Linguísticos, v. 10, n. 26, p. 49-71, 2020.

SCHECHNER, R.; BRADY, S. Performance studies: an introduction. 3. ed ed. London: Routledge, 2013.

SCHNEIDER, K. P. 2. Methods and ethics of data collection. In: A. H. Jucker; K. P. Schneider; W. Bublitz (Orgs.); Methods in Pragmatics. p.37-94, 2018. De Gruyter. Disponível em: <https://www.degruyter.com/document/doi/10.1515/9783110424928$\underline{002 / \mathrm{html}>}$. Acesso em: 5/4/2021.

SCHÜTZE, C. T.; SPROUSE, J. Judgment data. In: R. J. Podesva; D. Sharma (Orgs.); Research Methods in Linguistics. $1^{\circ}$ ed, p.27-50, 2014. Cambridge University Press. Disponível em: <https://www.cambridge.org/highereducation/books/research-methods-inlinguistics/C786E6A515E3CBF697D7309441A19EE8?chapterId=CBO9781139013734A013 \#contents>. Acesso em: 5/4/2021.

SHAKESPEARE, W.; RAFFAELLI, R. Do jeito que você gosta = As you like it. Florianópolis: Editora da UFSC, 2011.

SIMONOV, V. P. Il Metodo Stanislavskij e la fisiologia delle emozioni (título original: Metod K.S. Stanislavskogo i fisiologija emocij), Moscou, 1962. Disponível em: https://www.teatrodinessuno.it/doc/stanislavskij/fisiologia-emozioni. Último acesso: 05 de abril 2021. 
SKINNER, V. J.; LEKKAS, D.; WINNING, T. A.; TOWNSEND, G. C. Designing Relevant and Authentic Scenarios for Learning Clinical Communication in Dentistry Using the Calgary-Cambridge Approach. Creative Education, v. 03, n. 06, p. 890-895, 2012.

STANISLAVSKY, K. A preparação do ator. Rio de Janeiro (RJ): Civilização Brasileira, 2008.

VEDDER, I.; RÜCKL, M.; SANTORO, E. Contesti di apprendimento di italiano L2: tra teoria e pratica didattica. Firenze: Franco Cesati, 2013.

VERSCHUEREN, J. Contrastive Pragmatics. In: J.-O. Östman; J. Verschueren (Orgs.); Handbook of Pragmatics, 2016. Amsterdam: John Benjamins. Disponível em:

<https://benjamins.com/\#onlineresources $>$.

WHARTON, T. Pragmatics and Non-Verbal Communication. Cambridge: Cambridge University Press, 2009.

WILDNER-BASSETT, M. E. 'Coexisting discourse worlds and the study of pragmatic aspect of learners' interlanguage'. In: W. Olesky (Org): Contrastive Pragmatics. p. 251 - 275, 1989. Amsterdam: John Benjamins.

YUAN, Y. An inquiry into empirical pragmatics data-gathering methods: Written DCTs, oral DCTs, field notes, and natural conversations. Journal of Pragmatics, v. 33, n. 2, p. 271-292, 2001. 
ANEXOS 


\title{
ANEXO I - TRANSCRIÇÃO DOS ROLE PLAYS UTILIZADOS NO QUESTIONÁRIO
}

\author{
Vídeo 1 (V1) "água" - dupla PK ("não atrizes") \\ P: senti... è un'oretta che corro come una... un'affannata perché... ho voluto fare anche la \\ spesa prima di venire qui... due telefonate... avresti mica un bicchiere d'acqua? perché \\ sono... sono morta di sete.... \\ $K$ : e si... sì... si... ce l'ho sempre l'acqua lo sai... aspetta che... \\ $P$ : tu che vai in giro con le bottigliette... \\ $K: \grave{e}$... infatti \\ $P$ : ... nella borsa... \\ $K$ : ... ma te la do in un bicchiere... \\ P: si... si... va bene, grazie... \\ $K$ : invece che nella bottiglietta dove ci ho bevuto già io... \\ $P:$ oh... \\ $K:$ tieni... \\ P: berrei anche dalla bottiglia... grazie...
}

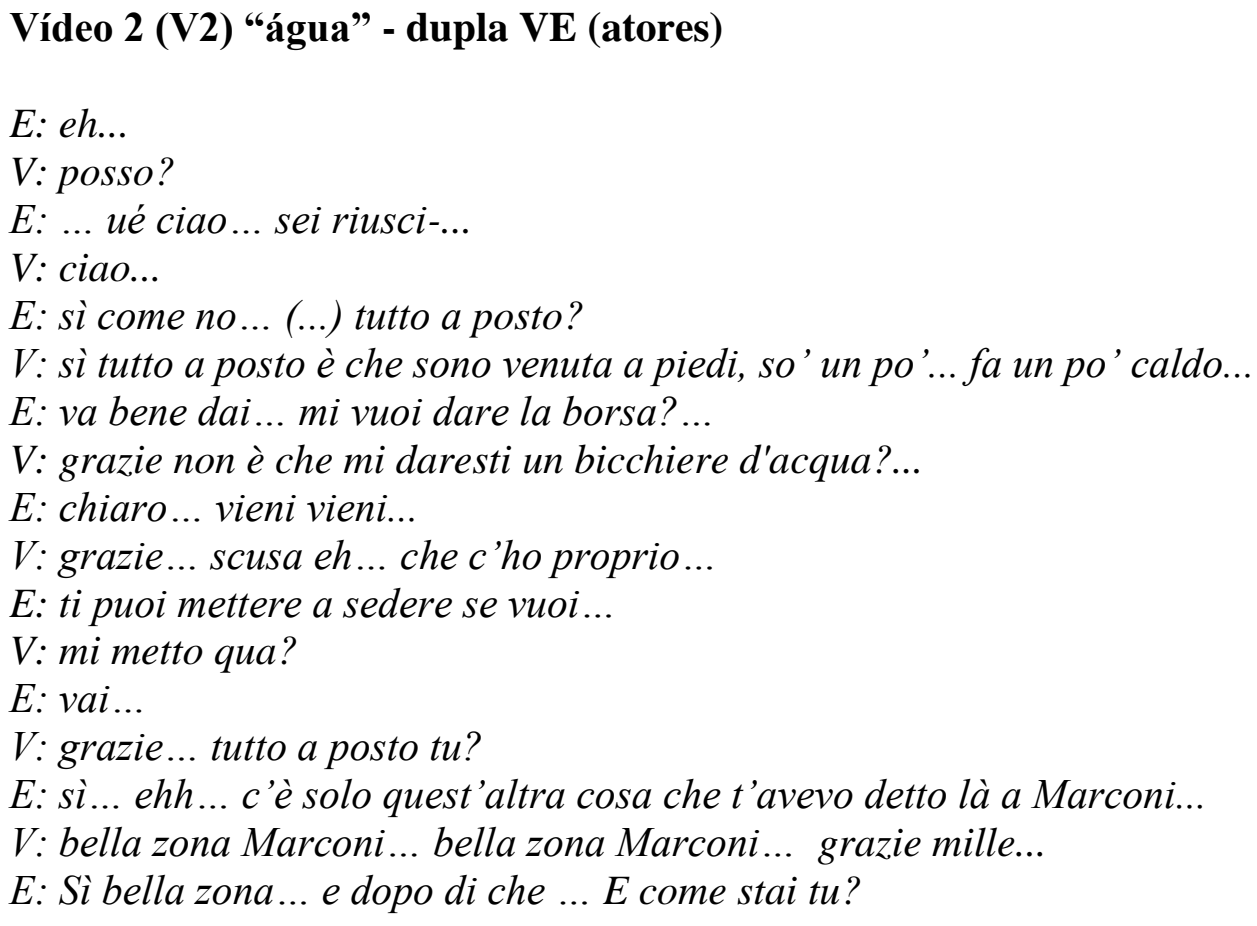

\section{Vídeo 3 (V3) "celular" - dupla LM (atores)}

L: che hai fatto oggi?

M: niente sono stato in giro e poi mi ha trovato un amico che sta tornando di un viaggio... L: ah bello...

M: sì, infatti, è stato parecchio... anzi, fammi vedere che ore sono... 
L: ti devi sbrigare?

M: si... si... mi sai dire l'ora?

L: si... un secondo...

M: che...

L: sono le due e mezza...

M: ... è tardissimo, mo' è arrivato... aspetta... non funziona ...

L: all'aeroporto...

M: sì, sì.. è arrivato è arrivato in aeroporto poco fa e lo devo chiamare lo devo chiamare... non mi funziona il telefono... sent-... posso.. posso fare una chiamata al volo...

L: certo...

M: grazie, grazie ... reggimi un attimo solo grazie... ok allora...

L: calma...

M: ok....

L: tranquillo... ti accompagno io se serve sono in macchina... tranquillo

M: ok

L: tranquillo... ma ti sei proprio dimenticato?

M: sì...

L: annamo bene...

\section{Vídeo 4 (V4) "celular" - dupla NG ("não atores")}

N: mi scusi...

G: prego...

$N$ : le devo chiedere un favore grosso però...

G: dica...

$N$ : nel senso che ho un'urgenza e non mi prende il cellulare perché... perché non lo so... forse qui è... c'è la TIM che non funziona...

$G:$ (rumore)

$N$ : è... ho un amico che mi sta arrivando... dall'aeroporto e ho bisogno di dirgli una cosa urgentemente...

G: va bene...

$N$ : se mi fa questo grossissimo favore... le pago caso mai la...

G: si figuri

$N$ : la telefonata ... grazie mille...

G: prego...

N: grazie...

\section{Vídeo 5 (V5) "caneta" - dupla NG ("não atores")}

$N$ : mi scusi, non avrebbe per caso una penna che devo segnarmi un numero che ho appena visto?...

G: è... no... mi dispiace...

$N$ : vabbé... pazienza ... grazie mille lo stesso... arrivederci 
E: se ti... io c'ho una cosa di sinusite, appena prendo un goccio d'acqua ... mi devi scusa'... però... se posso fa' tipo una piccola doccetta, una sciacquata ... calda $V$ : certo....

E: grazie alla grande... grazie

$V$ : certo... vuoi che ti prendo qualcosa...?

E: sec'è....

$V$ : sta tutto li...

E: insomma... sì sì lo trovo lo trovo insomma sta tutto più o meno...

$V$ : si si si... insomma... se vuoi che ti prendo qualche cosa ... un'asciugamano... qualche...

E: eh, si c'è un asciugamano sì... magari... giusto per... non lo so, ma guarda... solo che è proprio una cosa una cosa che c'ho bisogno... se no...

$V$ : dai vieni 


\section{ANEXO 2 - TRANSCRIÇÃO DAS ENTREVISTAS RETROSPECTIVAS ENTREVISTA PARTICIPANTE G}

S: Buongiorno... mi senti?

G: Pronto...

S: Tutto bene ? ecco... mi senti?

G: Sento molto poco...

S: Ah sì... adesso mi senti?

G: Pronto...

S: Pronto... adesso... mi senti?

G: Sì, adesso sì... dimmi...

S: Ecco... Allora... hai guardato già il video?

G: Sì, tutti e due...

S: Ecco... allora, io ho qua alcune domande, sono otto domande... no... nove domande, ok?

G: Va bene...

S: La prima è... considerando che sapevi delle registrazioni, quanto spontaneo è stato per te lo svolgimento delle azioni proposte?

G: Mah... diciamo... normale... insomma ecco...

S: Ah... ok... e qual è stata la cosa più facile da fare?

G: Dare il cellulare a quella signora che me l'ha chiesto...

S: Hummm, ok. E la cosa più difficile?

G: Beh, veramente, di difficile non ho trovato niente.

S: Niente? Ah ok.

G: Si.

S: Allora, se facciamo attenzione alla situazione del video... avevi già visto o vissuto una situazione così?... Simile a quella a cui hai dovuto partecipare?

G: No, in effetti non ho mai vissuto una situazione del genere...

S: Sia del cellulare che della penna?

G: Sì, esatto... No della penna sì, qualche volta mi è stata chiesta una penna... il cellulare mai.

S: Ah ok. Allora, cosa ti ricordi di quello che ti è stato proposto di fare?

$G$ : Beh, cioè... veramente io non mi ricordavo più niente a essere onesto...

S: Ah ok... allora, se osserviamo lo spazio in cui è avvenuta la situazione... secondo te quanto naturale o vicino a spazi reali è questo spazio del video?

G: Eh... non ho capito la domanda, scusa.

S: Allora, visto che era una via... era una cosa vera, quanto naturale per te è stato questo spazio se pensiamo alla situazione?

G: Mah... abbastanza naturale diciamo...

S: Ok e questo spazio ti è sembrato adeguato alla situazione? Sia alla penna che al cellulare?

G: Sì... può capitare che qualcuno per strada ti chieda qualcosa, principalmente una penna, il cellulare è molto più difficile che qualcuno ti chieda l'uso del tuo cellulare...

$S:$ Ok, è... questo spazio ... è... fare il video in questo spazio ti ha aiutato a svolgere le azioni?

G: No, qualsiasi spazio sarebbe andato bene lo stesso, diciamo...

S: Ah ok, perfetto... Allora, per quanto riguarda il modo in cui hai sentito la richiesta e come ti muovevi, come hai fatto le azioni... questi aspetti ti sembrano naturali o vicini a come agisci nella vita reale?

G: Sì... sì, è molto reale e molto vicino.

$S$ : E c'è qualcosa che hai fatto nel video che non faresti mai o che faresti in modo diverso nella vita reale?

G: No, in effetti, quello che ho detto e ho fatto nel video è quello che normalmente faccio realmente.

$S$ : Ah ok, perfetto, allora... ci sono ancora tre domande va bene?

G: Va bene, dimmi.

S: Ehhh... quanto adatte alla situazione proposta ti sembrano le azioni svolte da te nel video?

$G$ : Ė... non ho capito, puoi ripetere? 
S: Quanto adatte alla situazione proposta... sia alla situazione della penna che del cellulare, $t i$ sembrano le azioni svolte da te nel video? Sono azioni adatte a quel tipo di richiesta?

G: Sì... sì...sì, penso di sì, sì...

S: Ok, grazie... allora, prova a rivolgere l'attenzione a quello che viene detto, ovvero, alle parole e alle espressioni che hai scelto per ottenere quello di cui avevi bisogno... o per ottenere no... per rispondere a quella richiesta... quanto naturale ti sembrano queste scelte linguistiche?

G: Sono cose che usualmente... uso... nella vita reale, nella vita quotidiana...

S: Perfetto, perfetto... ehhh questi elementi ti sembrano adatti alla situazione? tipo... le tue scelte linguistiche ti sembrano adatte?

G: Sì.. sì sicuramente sì.

S: Ok... hai altre osservazioni da aggiungere sulla naturalezza del video?

G: No... no... va tutto bene così.

S: Ti sembra molto naturale... quindi? O poco naturale?

G: Sì... molto naturale.

S: Ah ok, grazie, grazie... beh era questo...

\section{ENTREVISTA PARTICIPANTE K}

S: Allora, quello che volevo fare è un'intervista su quei video... ti ricordi... quelli che avete fatto per E?

K: Sì sì mi ricordo vagamente perché... una vita fa... cioè ... ne abbiamo fatti diversi... questo mi ricordo... no ma non è non so più quale adesso poi me lo... quando me lo fai vedere mi ricordo...

S: Sì vabbè sì sì va bene sì va bene... io adesso ti invio il video....

K: Uhum...

S: Sono due... ti invio prima... sono qua... aspetta... è... ecco... guardiamo e poi... sono nove domande... tutte e nove te le farò per ciascuno dei video ok?

K: Uhum... va bene... tra l'altro il mio Skype mi dice che tu stai registrando... giusto per... quella che sta spiando... (risate) allora provo a fare il video io quindi

S: Sì... sì... per favore

$K$ : Ah sì aspetta... infatti adesso mi sta facendo vedere... "registrazione di prima"...

S: Ah dopo... dopo le registrazioni di prima c'è il link...

$K$ : Esatto ecco infatti devo guardare quella un attimo che non mi torna alla chat dove sta la chat no questo volevo fare... dove sta la chat adesso... ah eccola qua... sì... Adesso sì adesso mi hai dato su youtube giusto quello ah ok vedo ( $K$ guarda il video)... Ok è solo questo?

S: Sì sì questo è il primo adesso faccio le domande

$K: \grave{E} \ldots$....) non c'entra niente

$S:$ Va bene allora quando sei pronta...

K: Sì...

S: Sì ah ecco è la prima domanda... considerando che sapevi delle registrazioni quanto è...

spontaneo.... quanto spontaneo è stato per te lo svolgimento delle azioni proposte?

$K$ : Eh... su una scala di quanto? Cioè... o devo rispondere liberamente?

S: Puoi rispondere o su una scala di 1 a 5 o puoi rispondere anche liberamente

K: Allora per quello che mi ricordo.... visto che... credo che le registrazioni sono di 8, 9 anni fa... sì è direi che è stato comunque abbastanza spontaneo, anzi mi sono meravigliata che si riuscisse a farlo così spontaneamente anche se tutti sapevamo che era... che c'era la registrazione

S: Bello....

K: Quindi direi 4...

S: 4... quindi non è... non è stato difficile... oppure qual è stata la cosa più facile da fare?

K: Allora diciamo che non è stato difficile perché era con tutti amici, forse sarebbe stato più difficile con persone che non conosci... ah non lo so... io mi ricordo che non l'avevo... all'inizio pensavo che sarebbe stato strano ma poi alla fine no

$S$ : Ah perfetto ... però c'è qualcosa che è stato difficile? 
K: Non non mi ricordo...

S: E facile la cosa più facile? Ti ricordi?

$K$ : La cosa più facile... la cosa più facile forse... appunto, reagire a... agli altri... forse... io ero nel ruolo che dovevo reagire... l'altro prima mi diceva qualcosa io dovevo semplicemente rispondere e quindi quello è stato più facile, forse sarebbe stato più difficile dovermi inventare io l'altra parte di dialogo non so... più o meno questo

S: Ah.... allora e osserva... osserviamo con attenzione la situazione presente nel video... avevi già visto o vissuto una situazione simile a quella che hai dovuto partecipare... a cui hai dovuto partecipare?

K: Sì... cioè... che qualcuno ti chieda un bicchiere d'acqua?... di sicuro...

S: È una cosa comune e nella lingua italiana? Ecco... e cioè... è che sembra molto ovvio però a volte non è ovvio sai?...è proprio quello che vogliamo cercare... e cosa ti ricordi... anche se è stato molto tempo fa.... cosa ti ricordi di quello che ti è stato proposto di fare?

K: Cosa mi ricordo...

S: Sì...

K: Come istruzione tu vuoi dire?

S: Sì sia la istruzione scritta che quello che E ti ha detto...

$K$ : Mi ricordo che, appunto... che lei ci ha spiegato che servivano delle registrazioni perché doveva fare una ricerca sul modo di chiedere un favore in italiano e che aveva provato a farne di più spontanee ma era stato molto difficile sia per via della tecnica, cioè... nel senso che poi non si sentiva o non si vedeva bene... se lo fai in una situazione no, di vita normale... e non hanno studiato dove sei che sei in un posto dove tutti stanno fermi e solo le due persone interagiscono, quindi mi ricordo che ci ha spiegato questo e così ha chiesto naturalmente di... di essere più spontanei possibile e poi c'erano le istruzioni però non mi ricordo neanche più esattamente quanto prima ce le dava... o cosa... S: Ah ok ah... vediamo la prossima... osserviamo adesso lo spazio in cui è avvenuta la situazione... secondo te... quanto naturale o vicino a spazi reali in cui questa situazione potrebbe avvenire è lo spazio dove hai fatto il video?

$K$ : Beh quello era molto naturale era comunque una casa... era la casa di $B$ e $R$, naturalmente... $e$ quindi quello che abbiamo appena visto è molto realistico perché tu puoi essere a casa e aver invitato un'amica che arriva accaldata... assetata e ti chiede di bere...

S: Esatto... quindi e in che misura questo spazio ti sembra adeguato alla situazione che ti è stata proposta?

K: Molto adeguato...

S: Molto adeguato... ah ok... e questo spazio ti ha aiutato a svolgere le azioni? il fatto che era una casa che... ha aiutato?

K: a penso di sì... adesso non ho il confronto non so come sarebbe stato in uno studio di registrazione per dire... o in una classe all'università o altro, però, sicuramente... per quella situazione aiutava... non mi ricordo... c'erano anche situazioni forse in treno o altro. Ecco li... magari non ti aiuta, il fatto di essere in una casa... ti richiede più immaginazione ma per questo video che abbiamo appena visto andava benissimo.

S: va bene... ah grazie...allora...osserviamo il modo in cui rispondi la richiesta, come ti muovi come... gli atteggiamenti che hai e tutti questi modi... queste azioni... questi aspetti ti sembrano naturali vicino vicini a come agisci nella vita reale?

K: Mi sembra di sì... adesso l'ho visto solo una volta ma mi pareva di sì...

$S$ : C'è qualcosa che hai fatto nel video che non faresti o che faresti in modo diverso se fosse una situazione reale?

$K: N o$

S: No ... è più o meno come agisci normalmente?

$K: S i$

S: Ok... grazie... e quanto alla situazione proposta come ti sembrano le azioni svolte da te nel video?

$K$ : Mi sembra... sembravano adatte... molto adatte

S: Grazie... e adesso proviamo a rivolgere l'attenzione a quello che viene detto... ossia alle parole ed espressioni... quanto naturali ti sembrano queste scelte?

$K$ : Anche naturali... molto naturali...

S: Sì... e anche adatte? Perché... sembra naturale per la situazione e sembra anche adatte alla situazione? 
K: Sì sì

S: Sì... c'è qualcosa che hai detto che non diresti nella vita reale?

$K:$ No

S: No... ti sembra... eh l'ultima domanda... questa è l'ultima domanda del video ok? Hai altre osservazioni da aggiungere sulla naturalezza delle azioni nel video... in questo video?

K: Uh mi complimento con me con Paola per la naturalezza che siamo riuscite ad avere... (risos)

S: Brava... quindi ti è sembrato molto naturale... più naturale di quello che immaginavi?

K: Sì

S: Allora questo è stato un video... vediamo il prossimo... aspetta vediamo qua... dov'è... eccolo...te lo invio su Skype di nuovo... eccolo...

$K:($ risos $)$

S: È strano guardare i video? (risos) Ecco, fatto quando finisci me lo dici...

K: Fatto...

S: Allora quando sei pronta posso iniziare il test... allora... com'è guardare il video... così...?

$K$ : Ah, molto divertente...

S: Ok... saranno le stesse domande va bene? E quindi... la prima... considerando che sapevi delle registrazioni quanto spontaneo è stato per te lo svolgimento di queste azioni?

$K$ : Beh è riferito solo al... perché ho guardato... erano quattro adesso sì?

S: No, due... io ho usato due video... quindi questo e quell'altro del bicchiere d'acqua e.

$K$ : Ah ok perché ho visto anche altri video... di N... di R... tutto... sono continuati

S: Ahok

K: E invece no.. per questo ridevo un sacco... perché li vedevo tutti...

$S:$ Ahhh... no in realtà sono solo i tuoi, come... avevo mandato solo il tuo... ahhh è che c'è una lista su youtube

K: Ahhh...alla fine c'era quello dell'acqua... all'inizio c'era quello della doccia, dell'asciugamano ecc... e poi ne sono seguiti altri, alla fine c'era di nuovo quello che ho... che abbiamo visto... il primo che abbiamo visto...

S: Ah.. no no... adesso solo quello dell'asciugamano...

$K$ : Aspetta allora lo riguardo un attimo adesso perché ne ho visti così tanti

S: Sì sì

K: Così mi ricordo meglio tanto guardo solo il primo che era quello...

S: Sì..

K: Ok... aspetta che...ok

S: Fatto

K: Ecco, sì, sì... adesso ho fermato dopo questo... così mi concentro meglio solo su quello...

S: Ecco brava, brava... proprio questo... allora... sapendo delle... delle registrazioni quanto per te... quanto spontaneo è stato per te lo svolgimento delle azioni di questo video ?

K: Di nuovo molto spontaneo

S: Spontaneo... e qui... di nuovo... qual è stata la cosa più facile è la cosa più difficile ?

K: La cosa più facile... reagire a quello che diceva l'altra persona... la più difficile credo che sia prima quando si dice "chissà come sarà ... magari non... non mi... non mi sentirò spontanea" però in realtà...

S: Ahhh... tipo prima....

K: Prima... sì... prima che squilla il campanello... campanello... che devo prima aprire la porta

S: Ah... a questo non avevo pensato ancora ... ecco

K: Ero nel momento.... nel momento no... nel il momento è stato facile... cioè le cose da dire o da fare mi venivano così...

S: Ah, ecco, brava... allora... la situazione presente nel video... avevi già visto vissuto una situazione simile a quella a cui hai dovuto partecipare?

K: Sto pensando... probabilmente sì nel... nel corso del tempo che... che presti qualcosa a qualcuno perché, appunto, ne ha bisogno per qualsiasi ragione...

S: Ma pure... l'asciugamano per fare la doccia... sì? Questo pure?

K: Si...

S: Sì ok eh... eh qua cosa ti ricordi che ti è stato proposto da fare... di fare? 
K: Ehi non mi ricordo... cioè... le stesse cose di prima ... cioè, appunto, che e dovevamo fare le registrazioni che c'erano i foglietti però non mi ricordo più esattamente che cosa c'era scritto sul foglietto,.. cioè non lo so se io dovevo... se mi diceva... "propone di fare la doccia" oppure "reagisce un amico che arriva ed è zuppo" non mi ricordo più...

S. Tipo non ti ricordi un po' delle... di quello che E diceva o il modo in cui lei ha chiesto?

K: No, non mi ricordo... cioè, mi ricordo solo quello che ho detto prima... cioè che lei ci aveva spiegato perché le servivano queste registrazioni e di cercare di agire spontaneamente, però non mi ricordo più il... cioè, istruzioni più precise di queste non me le ricordo..

$S:$ Ok... eh lo spazio qua, secondo te quanto naturale è questo spazio per questa situazione

$K$ : Anche qua molto...

S: Anche qua

K: Sì... anche qua molto naturale,

S: Molto naturale, ok... e qua lo spazio ti ha aiutato?

K: Sì anche, di sicuro ...

S: ̇̀ anche adeguato?

K: Sì... è anche adeguato sì sì

S: Credi che... ad esempio arrivare a casa di un amico bagnato fradicio e chiedere un asciugamano...

K: Può capitare quindi sì, sì... da queste parti... sì ma credo anche lì può capitare no? Anche a San

Paolo piove..

S: Vero è vero... ah no, è perché questa situazione proprio... è una delle... delle situazioni in cui abbiamo dei dubbi, tipo se uno arriva a casa di un altro... e chiede di fare la doccia? Sai?

$K$ : Se questo va be.... chiaramente non lo so forse lì è culturale e non so se ci possono essere differenze, io non... non avrei problemi quindi, ripeto... la situazione era comunque con amici cioè, Paola è una delle mie migliori amiche per cui non avrei avuto nessun problema, è una delle mie migliori amiche nella vita vera non solo nella situazione fittizia...

$S$ : Sì.. quindi questo rapporto ha aiutato...

K: Penso di sì

$S: O k$

K: Però non mi... non mi creerebbe problemi la situazione di per sé perché se una persona che arriva... poveraccia... bagnata fradicia sorpresa da un acquazzone cerchi di aiutarla... A me è capitato di arrivare così, adesso mi ricordo... sono arrivata una volta a casa di A così perché aveva cominciato a piovere talmente forte e eravamo fradici, solo il pezzetto dall'autobus all'appartamento era una cosa pazzesca... infatti mi sa che non so se ci siamo fatti la doccia però Amalia di sicuro e mi aveva asciugata...

S: No... carino questo... ecco... allora osserva il modo in cui hai fatto questa risposta alla richiesta e come ti muovi, che atteggiamenti hai assunto e il tono della voce che avevi... questi aspetti sembrano naturali o vicini a come agisci nella vita reale?

$K$ : Mi sembrano molto vicini

S: Molto vicini

K: E naturali...

S: Naturali... sì? ... c'è qualcosa che hai fatto che non faresti nella vita reale? O faresti in un modo diverso?

K: No...no... farei cosi

S: Proprio così

K: Sì...

S: Ok.. eh... quanto ha adatte alla situazione proposta ti sembrano le azioni svolte da te nel video?

K: Mi sembrano adatte

S: Ok... allora

K: Forse l'unica cosa che cambierei nella vita reale se fosse una persona veramente bagnata fradicia direi magari... "togliti le scarpe prima di andare in bagno" però non so se questo possa essere utile per la tua ricerca (risos)

S: (risos) Tutto è utile... brava... mi servono tutte le informazioni possibili... brava...allora... prova a rivolgere l'attenzione a quello che viene detto, alle parole e alle espressioni usate... usate da te, quanto naturali ti sembrano queste scelte linguistiche?

K: Molto naturali 
S: Sì? non cambieresti niente?

$K:$ No

S: No ... ok... e questi elementi e ti sembrano anche adatti... il modo in cui hai risposto alla richiesta ti sembra adatta a questa richiesta... adatto a questa richiesta?

K: Ai

S: Sì... ok allora... adesso abbiamo l'ultima domanda... se hai altre osservazioni da aggiungere sulla naturalezza... c'è qualcosa?

$K$ : No... ripeto... mi sembra che siamo riusciti ad agire... riusciti ad agire in modo... in modo molto naturale era... sarà stato un po' tutto e che, appunto, tutti ci conoscevamo noi conoscevamo B che era quella che ci chiedeva di fare queste cose e in più ci conoscevamo fra di noi, conoscevamo non so più se era $R$, probabilmente, che filmava... conoscevamo anche lui... per cui.... e questo sicuramente ha tutto aiutato

S: Ah ecco

K: Era una situazione particolare perché era fra amici, se fosse adesso non so in una situazione di ricerca in cui io non conosco chi la fa, non conosco le persone con cui interagisco e non conosco l'ambiente, magari, mi sarei sentita meno in grado di fare le cose in modo naturale non lo so, non posso dirlo perché non è capitato però diciamo che, sicuramente, quello ha aiutato... conoscere già gli ambienti conoscere già tutte le persone, anche altri che c'erano non so come stavano gli altri mentre facevamo... non mi ricordo più come facevamo perché non era grande la casa di B non so se gli altri stavano lì vicino in silenzio non mi ricordo però comunque conoscevamo tutti... ci conoscevamo tutti...

S: Eppure credi che il fatto che sia una situazione e quotidiana aiuta?

$K: S i$

S: Questo... pure questo... ecco grazie mille... abbiamo finito... era questo...

K: Prego, prego...

\section{ENTREVISTA PARTICIPANTE N}

S: Ciao... tutto bene?

N: Ciao... mi ero dimenticata di questi video...

S: Nooo... sì ma adesso che hai guardato... come ti pare?

N: Allora... come mi pare? Mi pare passato un secolo...

$S:$ Aspetta... non ti sento...

N: Ho detto... mi sembra che sia passato un secolo...

$S: A h \ldots$

N: Abbiamo fatto questa cosa... duemilaquindici?

S: Forse... duemilaquindici? Sì?

$N$ : È.. più o meno.. più o meno... vabbè... dunque... è come mi sembra... vuoi che io ti dica la mia impressione o vuoi farmi delle domande?

S: No... in realtà io ho... aspetta... nove domande qua... che devo fare... sono nove domande uguali per tutti e due i video, ok?

N: Sì...

S: Fammi solo... ah eccola... la prima è così... considerando che sapevi delle registrazioni...

$N:$ Si...

S: Quanto spontaneo è stato per te lo svolgimento delle azioni proposte?

N: Quanto... scusami.. .quanto che cosa?

S: Quanto spontaneo...

$N$ : Ah... è stato lo svolgimento...?

$S: S i$

N: Hum. ho una scala da uno a dieci oppure devo dirti molto o poco?

$S:$ Anche da 1 a 5 oppure dire se è stato spontaneo o...

$N$ : Ok... molto spontaneo... mi è venuto... ho parlato liberamente, non mi sono sentita artificiosa...

$S:$ Ah ok... è tipo... molto spontaneo... 
N: Sì...

S: Sì... ok... E qual è stata la cosa più facile... per te... da fare...?

$N$ : La cosa più facile è stata immedesimarmi nella situazione...

S: Hum... ok... e la cosa più difficile?

$N$ : Ah... cosa più... la cosa più difficile... ahhh... (inaudivel) ci devo pensare.... cos'è stato difficile? $\grave{E}$ stato difficile... cercare di parlare fluentemente senza... senza interrompermi... forse...

$S:$ Ah ok...

N: Pure... cercare... cercando (inaudível) di essere spontanea e di non creare una... una... uh mi si è spenta la luce, aspetta che me ne accendo un'altra... non fare un effetto artificioso...

S: Quindi questo... c'era... ce l'avevi un po' in mente questo quando facevi i video?

$N$ : ¿̇ insomma, sapevo che venivo... che venivo ripresa...

$S: O k \ldots$

N: E quindi anche se non sapevo esattamente i motivi, cioè, che tipo di ricerca doveva fare eccetera... ovviamente... sei un pochino più... così...

$S: O k$

N: Eri presa perché sapevi di essere ripresa da...

S: Ecco, vero... allora, la domanda due... è... osserva con attenzione la situazione presente nel video... oppure... l'abbiamo già osservata... avevi già visto o vissuto una situazione simile a quella a cui hai dovuto partecipare?

$N:$ No...

S: No? Della penna?

N: No... beh.... diciamo.... non per strada...

S: Ah ok, non per strada ... è... cosa ti ricor...-

N: Però... certo... vabbè, in un altro contesto sì, certo!

S: Sì... Di qualcuno che ti ha chiesto la penna o tu che hai chiesto la penna a un altro... questo è possibile?

$N$ : Ah guarda un momento... aspetta un momento perché... il video che mi hai mandato... non è quello sul cellulare?

S: Ah sì... forse ti ho mandato, quindi... prima il video del cellulare... quindi, parliamo del cellulare adesso...

N: Si, quello, esatto...

S: Perché ce ne sono due... il primo era il cellulare, mi sa e il secondo era la penna... è questo...

$N$ : Va bene...

S: Mi sono un po' confusa...

$N$ : Quindi... no... ritorno sul mio no... nel senso che non mi ricordo mai di aver dovuto chiedere in prestito un cellulare per una situazione d'emergenza...

$S:$ Ah, ok, ok... però... sembra una situazione possibile nella lingua italiana?

N: Ormai, quasi non più perché tutti hanno un cellulare, però può essere una situazione d'emergenza, certo, sì.

S: Ok. E cosa ti ricordi di quello che ti è stato proposto di fare? Ti ricordi di qualcosa?

$N$ : Mah sono passati quattro anni... (risos) (inaudivel) ... mi ricordo... allora, mi ricordo che le struzioni che mi ha datto B erano abbastanza vaghe...

$S: O k \ldots$

$N$ : Quindi che non... sì, mi era stato detto più o meno che cosa doveva rappresentare il filmato, però non mi era stato detto che parole utilizzare... quindi

$S:$ Ah, ok... in nessun momento?

N: Mi pare di no...

$S: O k$

$N$ : Mi pare di no...

S: Bene, bene...e ... hummm ... un'altra domanda è... se osserviamo lo spazio in cui è avvenuta la situazione...

N: Aham

S: Secondo te... quanto naturale o vicino a spazi reali... questo... scusa... vicino a spazi reali in cui questa situazione potrebbe avvenire è lo spazio dova hai fatto il video? 
N: Cioè, mi stai chiedendo se, dal punto di vista dello spazio, era una situazione plausibile?... era una situazione...

S: Più... più... se lo spazio era uno spazio che ti sembrava reale... e adatto alla situazione

N: Sì.

S: Si.

N: Sì, e perché no?! Sono per strada o...

S: Aspetta non ti sento...

$N$ : Adatto... ah ok scusa ... dicevo... ripeto, ripeto... dico... sono per strada, ho un problema... vedo una persona e penso che potrebbe essere la soluzione...

S: Ecco...

N: Quindi sì...

S: Brava... e però... questo spazio, essendo una strada vera... una via vera... questo ti ha aiutato a svolgere le azioni, in qualche modo? O ha... disturbato...

$N$ : Rispetto a quale altro tipo di spazio?

S: Tipo uno spazio creato... tipo... facciamo finta che questo è una via...

$N$ : Quella era una via... era una strada

S: Esatto... infatti, era uno spazio reale... girare questo video che ti chiedeva di pensare che eri per strada, in una strada vera, ti ha aiutato a fare il video, o no...

$N$ : Scusami, però, l'alternativa quale sarebbe stata, tipo farlo in un set...

S: Sì...

N: Cinematografico...

S: Esatto... un'aula all'università... una cosa così, che non è uno spazio vero...

$N$ : Allora un'aula all'università è uno spazio vero secondo me, in un 'aula all'università si sarebbe potuta creare quella situazione...

S: Si, però pensiamo che... nelle istruzioni veniva scritto... "sei per strada"

$N:$ Ah... ok...

S: Quindi...

N: Quindi tu mi stavi chiedendo se l'istruzione "sei per strada" mi ha aiutato?

S: Sì rispetto allo spazio... ops... non ti sento di nuovo...

N: Adesso... adesso ci sei?

S: Sì... sì... adesso sì...

N: Adesso sì... ok... è... se mi ha aiutato a essere più naturale intendi?

S: Sì... sì...

N: Cioè... se questo... se lo spazio reale, cioè, se sapere... se il fatto di sapere... in anticipo con l'istruzione che avrei fa-... chiesto in uno spazio mi ha aiutato... questo mi stai chiedendo?

S: No, in realtà è... se fare l'azione nella via, visto che l'istruzione ti diceva che eri proprio in una via... vera... se fare in uno spazio che non devi immaginare com'è questo spazio però avere questo spazio vero ti ha aiutato...

$N:$ No

S: Tipo...

N: No...

S: $O k$

$N$ : (inaudivel) No (risos)

S: No... bene

$N$ : Nel senso che (11'51'" non si capisce) dal punto di vista della resa del video è sicuramente più naturale avere una situazione del genere... ma per me che ho dovuto... che ho fatto questa cosa non mi ha aiutato, nel senso che avrei potuto immaginarmi la stessa situazione anche in un... in un contesto.. in uno spazio diverso.

S: Ok... capito...

$N: O k$

S: E quindi... però... questo spazio era adatto alla situazione, secondo te?

N: Sì... sì...

S: Si... ok... aspetta... un'altra... ah... osserviamo adesso il modo in cui hai fatto la richiesta... ossia... come ti muovi... che atteggiamenti hai assunto... che tono della voce avevi... questi aspetti ti sembrano naturali rispetto a come agisci nella vita reale? 
$N$ : Assolutamente sì...

S: Si?

N: Sì...

S: Ecco... c'è qualcosa che hai fatto nel video che non faresti mai o che faresti in modo diverso se fosse una situazione reale?

$N: N o \ldots$

S: No?

N: No... magari ciò̀... magari due giorni dopo avrei scelto due parole diverse o... che ne so... se invece che un uomo fosse stata una donna, non posso escludere che qualche cosa sarebbe stato diverso... ma no niente di fondamentale...

S: Ecco... quindi l'interlocutore può magari farci agire in un modo diverso però...

N: Sì... assolutamente sì...

S: Però il modo in cui hai fatto è il tuo modo reale?

N: Sì...

S: Ops... sì?

N: Sì... bisognerebbe capire che cosa intendi per modo... se per modo intendi la gestualità, il tono della voce... o la scelta delle parole... sono tante cose in realtà...

$S:$ No... in realtà la scelta delle parole è la prossima domanda...

N: Ok... allora sulla gestualità e sul tono della voce e su come mi sono posta io... fisicamente...

diciamo ... no... mi sono sentita... diciamo... mi sono sentita completamente naturale... è come... è come sono io...

S: Ecco... perfetto. Quando adatte alla situazione proposta... ti sembrano le azioni svolte da te nel video?

$N$ : Sì... le azioni....

S: Le azioni...

N: Allora, non lo so se è una risposta alla tua domanda... però ti dico lo stesso...

S: Sì.. sì...

N: Ho guardato due volte il video... allora... e quello che ho notato è che... e questo non mi ricordavo se era una struzione che mi ha dato B oppure no...

S: $O k \ldots$

N: Io non nomino mai il telefono...

S: Ah... ok...

N: Cioè... non dico mai... è quasi un sottinteso... nel senso che io non dico mai scusi mi può prestare il cellulare...

S: Sì... questo è interessante...

$N$ : Vedo che ho questo problema...

S: Ah sì...

$N$ : Sì... in realtà, evidentemente... ecco, questa è l'unica cosa...

S: Uhum...

$N$ : Che se come di... di immediata comprensione per una persona che vede questo video ...

S: Sì...

N: E deve capire che cosa sto chiedendo perché io non dico mai che cosa voglio, in realtà lo faccio capire dal contesto...

S: Ah ok capito... e dai gesti pure...

N: Dai gesti e poi dico... dico... "dovrei... ho urgenza di contattare un amico..." non so che cosa e quindi è chiaro che ho bisogno del telefono e poi dico forse in questa zona non prende bene...

S: Ah ok... forse... può darsi che... per... perché chiedere in cellulare a qualcuno è una cosa difficile da fare... o no... secondo te...?

$N:$ No... no... no... no...

S:: Ok... ah va bene...

$N$ : (inaudivel) questa scena... direi... "scusi, avrei bisogno..." cioè... in qualche modo nominerei la cosa di cui ho bisogno... cioè... mi verrebbe da dire "scusi mi potrebbe prestare un attimo il cellulare perché ho questo problema?"

S: Ecco... 
$N$ : Invece in questo caso l'ho... l'ho completamente eliminata questa cosa, sono partita dicendo qual era il mio problema e...

S: Sì... questo é molto interessante

N: Pensando che pure l'interlocutore avrebbe capito di che cosa avevo bisogno...

S: Sì... questo è molto interessante anche perché ... e ci sono varie cose che dicono che... a cui dobbiamo fare attenzione ... ecco... dobbiamo fare attenzione a non riprodurre quello che viene scritto... e... a fare le azioni in modo più libero... non so se l'hai fatto da sola o se questa è stata una richiesta però interessante notare questo...

$N$ : infatti... non mi ricordo se B mi aveva detto di non.. cioè... non nominare... non dire esattamente ciò di cui avevo bisogno, questo non me lo ricordo...

S: Poi faccio un'intervista anche con lei... eh... un'altra domanda... adesso sì rispetto alle... alle parole

N: Sì...

S: Vediamo... adesso possiamo rivolgere la nostra attenzione a quello che viene detto... ovvero, alle parole ed espressioni scelte da te per ottenere quello che hai bisogno... quello di cui avevi bisogno... quanto naturali o... è ... quanto naturali ti sembrano queste scelte?

$N$ : Mah... io ho parlato veramente a ruota libera e ho detto... ho usato veramente le parole che userei in una situazione simile... l'unica cosa che mi è saltata all'occhio o meglio all'orecchio...

S: Sì...

$N$ : È che io non ho fatto una richiesta esplicita di avere il cellulare dell'interlocutore

S: Ecco...

N: Però per il resto le mie parole sono state molto... ciò̀.... erano volte... per me era importante che l'altra persona capisse che non volevo nien-...cioè... che ero veramente in una situazione di bisogno era importante che capisse che non ero una che stava chiedendo soldi o che voleva fregare qualche cosa... o cosa del genere no? Quindi era molto importante pormi, sia come persona e anche a parole dico... con una richiesta fatta in un modo gentile, però anche in modo diretto, diciamo... della richiesta che stavo facendo...

S: Capito, quindi le parole e le espressioni erano quotidiane per te? Sì?

N: Sì... sì assolutamente.

S: Oltre che quotidiane... erano adatte, secondo te, a questo tipo di richiesta?

N: Si.

S: $S i$ ?

N: Sì però, scusami... perché... allora... io sono quella che ha fatto l'inter... cioè... la scena... perchè tu chiedi a me se ho usato delle parole che mi sembrano adatte? Perché non lo chiedi a uno che... cioè... è chiaro che ho usato delle parole che mi sembrano adatte... mi sembra logico no?

S: Sì.. sì...

N: Ma perché pensi che io potrei... "no, ho usato delle parole non adatte"

S: No... in realtà... perché.. quando facciamo questo tipo di ricerca, una delle cose che facciamo sempre è chiedere ... non so... agli italiani, per esempio... se questo sembra adatto, se questo sembra reale, peró, per me, è interessante anche sapere il punto di vista interno... di chi l'ha fatto... perché una volta... perché ci sono studiosi che dicono che... a volte le persone che devono fare i video possono inventare delle cose o fare delle cose non così naturali perché sanno che sono registrate... mi senti... ecco... tornata...

N: Poco... scusami

S: Tornata...

N: Sì... sì.. scusami

S: Ah è che mi ha...

N: Intendi... intendi dire che...

S: ̇̀ che voglio tutti e due i punti di vista.. ho è che si è bloccato il cellulare... intendo... io voglio tutti e due i punti di vista.. quello esterno...

$N: O k$

S: E quello interno... per poter sapere se... una cosa che sembra adatta... una cosa che sembra reale a tutti quelli che la vedono è reale anche per chi l'ha fatta sai? È una cosa vicina alla realtà di chi ha girato il video...

N: Ok... d'accordo.... sì... sì... 
S: Tipo...

N: Ok... era solo una curiosità...

S: Sì sì... anche... se vuoi altre... altre domande... me le puoi anche fare... perché, in realtà, questa cosa della... della lingua, ad esempio... io devo dire... devo chiedere... se c'è qualcosa che hai detto nel video che non diresti oppure che diresti in modo diverso oggi...

$N$ : Dovrei rivederlo ancora una volta... non mi sembra...

S: Una parola...

N: Non mi sembra... cioè... l'unica cosa... l'unica parola è proprio l'oggetto di cui avevo bisogno che non lo dico mai...

S: Ecco...

N: Non dico mai la parola telefono o cellulare...

S: Sì però questo...

N: Penso che lo capista l'interlocutore ma io non lo dico mai, quindi, forse quello.

S: Però non hai messo lì nessuna parola che non è normale per te?

$N$ : Assolutamente no...

S: Ecco... l'ultima domanda di questo video è...

N: Sì...

S: Hai altre osservazioni da... da aggiungere sulla naturalezza delle azioni che hai svolto nel video?

$N$ : Ė... devo parlare sempre solo per me stessa, cioè, non per l'interlocutore... non dell'altra persona?

S: Anche dell'altra persona puoi parlare

N: Ok... ok... allora, secondo me una cosa poco naturale è il fatto che l'altra persona non abbia detto praticamente niente fino alla fine...

S: Sì...

N: Cioè... in realtà era un po' il suo compito se ben mi ricordo... cioè... lui doveva semplicemente rimanere lì abbastanza passivo...

S: Uhum....

$N$ : Ascoltare quello che io dicevo... e alla fine dire "sì, va bene" o qualcosa del genere...

S: Sì...

N: Però diciamo che in una situazione reale, probabilmente, ci sarebbe stata un 'interruzione da parte dell'interlocutore che mi avrebbe fatto magari qualche domanda... o mi avrebbe detto "ahhh, sì però sono di fretta..." oppure "ahh, no..." qualche... qualche cosa in più da parte sua...

$S: O k \ldots$

N: Non una cosa così neutra fino alla fine...

S: Capito... quindi, la naturalezza dell'altro sembra un po'...

N: Si lui era un po' timido...

S: Ok... allora facciamo l'altro video?

$N: O k \ldots$

S: Le domande sono più o meno... sono le stesse domande, quindi, le cose che hai già... che sono uguali le possiamo anche saltare

N: Va bene...

S: Va bene?

N: Sì d'accordo...

S: Allora...

N: Torno fra due minuti...

S: Sì ecco... ciao...

(dopo due minuti ... il tempo di guardare l'altro video)

S: Eccomi

$N$ : Eccoci qua...

S: Ecco... guadato?

$N: O k \ldots$

S: Di questo ti ricordi altre cose?

$N$ : Ė... vabbe... sì... adesso quando sì è vero ne avevamo fatti due... però... niente di che...

S: Allora... va bene... la prima domanda, di solito, sempre... è... considerando lo spazio... no scusa... considerando che sapevi... eh... mi senti? Ops... tornata? ... ecco... tornata... tornata.... è... 
considerando che sapevi delle registrazioni, quanto spontaneo, in questo video è stato lo svolgimento delle azioni?

N: Molto...

S: Molto spontaneo....

N: Molto

S: $O k \ldots$

N: Sì...

S: E la cosa più facile di questo video, qual è stata?

$N$ : È stata... fare la mia richiesta nel modo più diretto e più semplice possibile, mi è anche venuta fuori proprio bene la... la domanda ...

S: Ecco... e quella più difficile? C'è qualcosa di difficile o no?

$N: N o$

S: No? Facile questa...

N: Sì...

S: Piú facile del cellulare?

N: Sì... più facile perchè dovevo parlare di meno.. era più veloce ... e poi forse è anche una situazione più... più facile... nel senso che è più facile chiedere una penna... che chiedere di fare una telefonata col cellulare di un'altra persona... non necessariamente perché è più facile che una persona abbia una penna in mano piuttosto che un cellulare, ma perché è una richiesta molto... molto...

S: Molto...

N: Povera... che nessuno se ha... se ha con sé una penna te la rifiuta... nessuno..

S: Ecco...

N: No? Quindi è una domanda che fai senza grossi problemi, non è una cosa...

S: Ecco, proprio...

N: Mentre, magari un cellulare uno può avere qualche problema in più a prestarlo, no?

S: Uhum

N: Questo...

S: Quindi la situazione, la situazione è... questa è anche al seconda domanda... è... avevi già visto o vissuto una situazione simile a questa?

N: Si.

S: Sì...

N: Sì...

S: Secondo te è quotidiana nella lingua italiana?

N: Sì... sì...

$S: O k$

$N$ : Ripeto, adesso sempre di meno perché il fatto che tutti noi abbiamo in tasca un cellulare e quindi ci possiamo prendere delle... degli appunti direttamente sul cellulare... quindi la penna non è più così determinante, diciamo.

S: Sì... però è una cosa normale, ancora? Sì?

$N: S i$

S: Ecco... è sembra-... è che queste sono cose che sembrano ovvie, però quando facciamo le ricerche dobbiamo sempre vedere... "no ma è così o non è così..."

N: Ho capito... capisco...

S: Allora, cosa ti ricordi di quello che ti è stato proposto di fare? Qualcosa di speciale o no?

$N$ : Mi ricordo che B mi ha (inaudivel)... una... un contesto abbastanza generico...

$S: O k \ldots$

N: E mi aveva detto che cosa dovevo chiedere io a questa persona...

S: Ahok...

N: Ma non mi aveva dato delle indicazioni su come chiederlo, se dare del Lei, se dare del tu ... hummm... se fare la richiesta molto articolata... hummm... tutte queste cose le ho poi decise io in base a quello che mi sembrava giusto in quel contesto...

S: Ecco, grazie... humm... vediamo la prossima... è... qui è lo stesso... lo spazio è lo stesso... è ... per la situazione... la penna... questo spazio è naturale? 
$N$ : ̇̀ qui torniamo, secondo me, alla... alla prima cosa che ti ho detto, cioè... adesso è diventato un po' meno naturale perché, secondo me, meno persone vanno in giro con una penna in tasca o nella borsa...

S: Si... capito... capito... quindi...

N: Dieci anni fa, cinque anni fa era più naturale, adesso lo è meno e secondo me, più passa il tempo e meno sarà naturale perché questo oggetto diventerà un... non più una cosa indispensabile

S: Sì...

N: Quindi non tutti ce l'avranno a portata di mano...

S: Oppure... oppure per strada perché... per strada...adesso... sembrava più facile, adesso sembra più difficile, al posto che andare... non so...

N: Soprattutto se fai una richiesta a un uomo...

S: Ahhh

N: Una donna... con il fatto che ha una borsa, molto spesso ha una penna in ... ancora in borsa

S: E un иomo...

$N$ : Un uomo molto meno...

S: Ah, ho capito... a questo non avevo pensato... vero... vero.. uhmmm... allora, lo spazio se è naturale... e se è adatto... anche... un po' adatto... o no? Sì?

N: Sì.. sì... sì... certo...

S: Uhm adesso, il modo in cui hai fatto... è... le tue azioni... in cui hai fatto la richiesta... è... questi aspetti, anche in questo video, ti sembrano naturali o vicini a come agisci? Continua a...

N: Sì...

S: Continua...

N: Sì...

S: Ok... e c'è qualcosa che hai fatto che non faresti?

$N: N o \ldots$

$S: N o$ ?

N: No...

S: Ok... ahhh, allora... vediamo qua... i gesti anche i gesti sono adatti a questa situazione? Il modo in cui hai fatto la richiesta?

$N$ : Sì... sì perché sono... fanno parte di me, quindi erano molto... erano naturali e poi vabbè, se uno gesticola tanto, gesticola tanto, se uno gesticola poco, gesticola poco... cioè, non mi sono trattenuta, non ho fatto niente di innaturale... il gesto per me evidenzia sempre o sottolinea qualche cosa no? In questo caso mi sono sembrati naturali, sì... normali...

S: Ecco.. uhm, la prossima domanda è sulla... sulle parole e scelte linguistiche che hai fatto... queste scelte sono... anche... naturali o sono cose che avevi detto già in altre situazioni.. in cose reali?

N: Sì... in una situazione... sì , sì. Io dico... "non è che avrebbe... non è che avrebbe un... una penna?". Che è un modo un po' particolare, se non si è italiani...

S: Sì..

N: Non è facile dire... "non è che avrebbe una penna?"

$S: O k \ldots$

N: Però... per un... per un madrelingua è un modo sufficientemente formale... ma anche molto gentile di chiedere qualche cosa... perchè questo "non è che avrebbe" implica... "non è che, per caso... scusi... per caso" ah ecco, diciamo che "non è che avrebbe significa "scusi, lei, per caso, ha una penna?"

S: Sì...

N: Quindi... un modo...

S: Però, questo lo usi normalmente?

N: Uguale...

S: Ah... sì?

N: Sì...

S: Tipo... è una cosa quotidiana per te?

$N: S i$

S: Questo modo di trattamento...

$N$ : Assolutamente sì, sì... 
S: Uhm... e anche... secondo te... è adeguato?... questa forma... questo modo di dire... a questa situazione? Secondo te... sì?

N: Si.

S: Ecco... allora, ah.. l'ultima domanda è... se hai altre osservazioni sulla naturalezza di queste azioni...

N: No.. direi che... sai che... in questo caso il... la risposta dell'interlocutore e il fatto che

l'interlocutore sia stato così zito, fino alla fine...

S: Sì...

N: Non era così... non saltava così tanto all'occhio come nella prima situazione perché era più appropriato.. la mia richiesta era molto breve...

S: Sì...

N: Molto chiara e molto diretta.

$S: O k \ldots$

$N$ : Quindi è normale che lui non mi abbia detto niente fino alla fine... e che mi ha risposto con un semplicissimo e gentile "no, mi dispiace".

$S: A h, o k$.

N: Quindi, a quel punto non mi aspettavo niente altro, l'ho ringraziato dicendo "grazie lo stesso".. "non importa"... una cosa del genere. Quindi è una situazione assolutamente... cioè, la seconda situazione, il secondo video, lo trovo assolutamente... assolutamente naturale...

S: Naturale... ok

N: Sì.. sì... non vi (inaudivel)

S: Quindi, è una cosa proprio... comune... proprio

N: (inaudivel)

S: Proprio... possibile...

N: Sì... sì direi...

$S:$ Ahok...

N: Sì...

S: Ecco... quindi... abbiamo finito... se hai qualche dubbio....

$N$ : No... fammi vedere il risultato di tutto... io voglio vedere tutto il risultato di queste cose...

S: Si!!!!

\section{ENTREVISTA PARTICIPANTE P}

S: Fatto? Sì... Allora... quanto spontaneo è stato per te lo svolgimento delle azioni proposte?

P: Ridimmi...

S: Considerando che sapevi delle registrazioni quanto spontaneo è stato per te lo svolgimento delle azioni proposte?

P: Sì spontaneo...

S: Spontaneo... ok... e qual è stata la cosa più facile da fare?

$P:$ Allora, in che senso...

S: In questo video per te qual è stata la cosa più facile?

$P$ : In questo video... la cosa più facile... tutto nel senso... era... era facile...

S: Era facile...

$P$ : Ė... sì, la situazione era facile....

S: Ah, la situazione era facile.... ok .... e qual è stata la cosa più difficile?

$P$ : Non mi ricordo... non mi sento.... provo a ricordarmi, a andare indietro... a ritroso... e forse quella di essere chiara, di parlare chiaramente sapendo di essere registrata

$S$ : Ah ok, di essere chiara, di parlare chiaro sapendo di essere registrata ... questo... oh è che... è che il suono è un po' tagliato qua ... ok

$P:$ Si.

S: La seconda domanda... osserviamo con attenzione la situazione presente nel video, avevi già visto o vissuto una situazione simile a quelle a cui hai dovuto partecipare? 
$P:$ No, di registrazione no

S: No, non di registrazioni, però la situazione... quella che hai fatto

P: Ah la situazione sì.. la situazione di chiedere un bicchiere d'acqua, certo sì... sì...

S: Hai già visto o vissuto qualcosa così?

P: Certo, sì certo...

S: E cosa ti ricordi di quello che ti è stato proposto di fare? Ti ricordi qualcosa o no? O il modo in cui ti è stato proposto...

P: E no... cioè come... se mi ricordo qualcosa... nulla di particolare, come volevo... come volevo l'acqua ma no... cioè... nulla che mi è rimasto... come dire... nulla di particolare... una cosa strana che ti chiedono... o te lo propongono in modo strano...

$S:$ Ok ... però del...

$P$ : Non mi ricordo nulla di...

S: Però del processo ti ricordi... del processo... di come ti è stato chiesto? Qualsiasi cosa...

P: Sì sì ricordo... vabbè... come mi è stato chiesto l'ho sentito ora

S: $O k$

P: Forse non capisco la tua...

S: È... sì... è più o meno se ti ricordi del processo di grav-... di girare questo video... se lì c'era qualcosa ad esempio... se questo processo... come è stato proposto a te di fare questo video...

$P$ : No questo non lo ricordo... cioè... sì... diciamo mi ricordo di far... di simulare, simulare una situazione e nel modo... una situazione molto abitudinaria... comunque... che succede molto spesso in un modo eh... molto naturale... quindi ricreare quella situazione lì in modo naturale sapendo di essere registrata, questo mi ricordo...

S: Ah ok, perfetto... perfetto... allora... è... vediamo lo spazio... lo spazio fisico in cui è avvenuta la situazione... secondo te, quanto naturale o vicino a spazi reali in cui questa situazione potrebbe avvenire è lo spazio dove hai fatto il video?

P: Può essere benissimo... a parte che ero registrata, eravamo registrate... ma può essere una situazione molto reale, cioè, tu arrivi a casa di qualcuno e magari fa caldo sei di corsa... sei in ritardo e chiedi un bicchiere d'acqua quindi molto reale

S: Lo spazio proprio, la casa, era molto reale...

P: Sì... sì, certo.. sì

S: Ok. E in che misura questo spazio ti sembra adeguato alla situazione?

P: Adeguato... sì... per me, come ti dicevo, per me è stato girato, era uno spazio, cioè, non finto no?

Poteva essere in un bar, ma poteva essere benissimo al ristorante ovviamente... cioè uno spazio reale

S: Ecco, grazie... allora... questo spazio ti ha aiutato a svolgere le azioni? Essendo la casa di un amico... questo ti ha aiutato a svolgere le azioni?

P: Beh... l'azione era molto semplice no?... quindi quella di chiedere un bicchiere d'acqua... quindi, direi che... non è che mi ha aiutato quello spazio preciso, io avrei agito così in qualsiasi altro contesto... fuori... non era particolarmente... niente di speciale che mi ha aiutato nella situazione...

S: Ok... osserva ora e il modo in cui hai fatto la richiesta... ossia... come ti muovevi, che atteggiamenti hai assunto, che tono della voce avevi... questi aspetti ci sembrano naturali o vicini a come agisci nella vita reale?

$P: S i$

S: $S i$ ?

P: Sì dai... sì... sì...

S: Ok... e c'è qualcosa che hai fatto nel video che non faresti o che faresti in modo diverso se fosse una situazione reale?

P: Non credo... no credo di no...

S: Ok perfetto... quanto adatte alla situazione proposta ti sembrano le azioni svolte da te nel video?

$P$ : Oddio... io non faccio niente, mi giro, mi tocco i capelli, aspetto che mi portino un bicchiere... beh... quanto adatte o non adatte... beh sì dai niente di... sono lì in... sono in attesa, ho fatto così...

S: Sì sì... anche la richiesta stessa... e il modo in cui hai fatto la richiesta ti sembra adatto?

P: Sì direi di sì, lo rifarei in questo modo...

S: Ok perfetto... un attimo... ecco... prova adesso a rivolgere l'attenzione a quello che viene detto o alle parole ed espressioni che hai scelto per ottenere quello di cui avevi bisogno... Quanto naturali ti sembrano queste scelte? 
P: Beh, penso abbastanza naturali, ma sapendo che stavo... che eravamo... che c'era qualcuno che ci stava registrando forse ho messo un'attenzione in più a una parola piuttosto che un'altra

S: Perfetto

P: La situazione, diciamo, la situazione era molto banale, molto semplice... credo che comunque abbastanza naturale, ma con un po' di... come dire... anche di influenza che viene dal fatto che sei.. che c'è qualcuno che ti registra...

S: Ok e... questi elementi che ti sembrano... questi elementi che hai scelto... proprio... tipo le parole le espressioni, anche quest'attenzione... questi elementi ti sembrano adatti alla situazioni ?

$P$ : Sì...

S: Sì... tipo... tipo sono parole che usi nella vita quotidiana?

P: Certo...

S: O hai... o c'è qualcosa che non diresti...

P: No... non ho usato... cioè... non è che mi sono trasformata e ho parlato in modo... magari ho usato di più delle forme di cortesia... ripeto... sapendo di ... comunque... sapevo di essere registrata ... quindi forse su qualche cosa magari ho fatto più attenzione, ma ... comunque naturale ...

S: Ma senza creare una cosa nuova... senza mettere una parola che per te non va bene...

$P$ : No no, completamente naturale... naturale sì...

S: Perfetto... l'ultima domanda su questo video è... hai altre osservazioni da aggiungere sulla naturalezza delle azioni da te svolte nel video?

P: No forse mi sentivo comunque osservata e allora magari anche il gesto di toccarsi i capelli è stato dovuto, non so... l'attesa del bicchiere d'acqua ma anche al fatto... se qualcuno ti stava guardando dall'esterno e allora magari...

S: Ok... era tipo una rappresentazione?

$P$ : E sì ma poco... mi sono rivista molto naturale cioè ... come mi vedo io è che non è...

S: E K? Cosa pensi delle azioni di K? Cosa pensi?

$P$ : Anche lei naturale

S: Sì? da quello che conosci...

P: Ho fatto più attenzione forse a me e non a lei ma sì... io direi naturale sia nel modo di parlare che nel modo di muoversi... naturalissima...

S: Perfetto ... proprio quella è la K che conosci ...?

P: Sì... sì... in una situazione molto naturale...

S: Perfetto... allora queste sono state le domande del primo video... adesso ti faccio vedere il secondo video ok?

P: Uhum

S: Secondo e ultimo video...

P: Vai... vediamo

S: Questo è un po' più lungo... molto poco...

$P:$ Adesso...

$S:$ Te lo invio adesso

$P$ : Vediamo se...

S: Poi farò le stesse domande... questo qua è il secondo video ...

P: Vediamo...

S: Fatto?

P: Allora, asciugamano...

S: Sei riuscita a guardare?

P: Sì, sì...

S: Ok, tutto... vuoi riguardarlo o no? Va bene così?

P: Posso guardare magari, visto che mi fai domande sulla....

S: Su tutto... sullo spazio...

P: Aspetta... si dai... riguardo, aspetta un attimo... vediamo un po'... vediamo un moment-... (não consegue rever) va bene così ma l'ho guardato bene

S: Va bene, la prima domanda... la solita... considerando che sapevi delle registrazioni quanto spontaneo è stato per te lo svolgimento delle azioni in questo video?

$P:$ Sì beh... anche in questo caso, spontaneo beh mi immagino che anche in una situazione senza essere registrata... richiesta ad hoc l'avrei fatta così.. avrei... cioè... è una situazione molto... molto naturale 
S: Perfetto e qual è stata la cosa più facile da fare qua?

$P$ : Eh la cosa più facile... non so... la cosa più facile... la cosa più facile... entrare ed esprimere quello che volevo

S: Questo...

P: Sì... tutto... la situazione è facile... come prima... una situazione comunque facile...

S: E quella più difficile? C'è qualcosa di difficile?

$P: N o$

S: No... ok...

$P: N o$

S: Va bene... allora osserviamo con attenzione la situazione proprio... questa situazione... hai già visto o vissuto una situazione simile a quella a cui hai dovuto partecipare?

P: Sì... mi è già capitato magari entrando... o a casa... oppure in un... in un altro luogo chiuso dopo essermi presa un acquazzone. Sicuramente mi è già capitato tantissime volte...

S: Però quella di... quella di dover chiedere a un amico di fare la doccia o un asciugamano anche questo?

P: No... di dover chiedere a un amico magari di fare una doccia ... oddio sai che non me lo ricordo ?!

S: Però è una cosa quotidiana o una cosa che è possibile che succeda...

P: Una cosa quotidiana no ma una situazione che... in cui sono bagnata e mi sono rifugiata a chiedere aiuto a qualcuno sicuramente... chiedere riparo è già successo... se ho già chiesto... in quell'occasione ho chiesto di cambiarmi.... sì... ma sì... se così magari non di far la doccia ma di cambiarmi si... di avere un vestito, un pezzo di sopra, magari delle calze che ne so...

S: Ok questo quindi è una cosa possibile nella lingua e nella cultura italiana?

P: Assolutamente

S: $O$ O

P: Cioè... è una situazione possibile indipendentemente dalla lingua è una situazione reale

S: Ok brava... allora qui ti ricordi come ti è stato proposto di fare? Come ti è stato proposto di fare... Ti hanno proposto di fare... ti ricordi qualcosa o no? della ... proprio della... della registrazione? Della registrazione...

P: Della registrazione...

S: Sì...

P: No... cosa mi è stato proposto... no non mi ricordo

S: Va bene...la prossima domanda.... adesso quella sullo spazio.

$P$ : È la memoria... troppi anni, non mi ricordo più

S: Allora... lo spazio in cui è avvenuta la situazione... seondo te... quanto naturale o vicino a spazi reali in cui questa situazione potrebbe avvenire è lo spazio dove hai fatto il video?

P: Sì è una situazione reale come ti dicevo può capitare a prescindere che lì era registrato... era la situazione richiesta... si è una situazione che può avvenire tranquillamente in qualsiasi momento

$S:$ Ok ... e essere a casa di un amico e chiedere un asciugamano o chiedere di...

$P$ : ̇̀ una situazione molto normale...

S: Molto naturale ok... e in che misura questo spazio ha... questo spazio è adeguato... per te o è una cosa che proprio possibile che accada?

$P$ : Sì sì sì come ti dicevo è una situazione.. è stata una situazione sì registrata richiesta... però è una situazione comunque reale o che è... possibile assolutamente e anche ripetibile... quindi...

S: E questo spazio ti ha aiutato a svolgere le azioni? Tipo... essendo la casa di un amico ti ha aiutato o no?

P: Sì... mi ha aiutato a sentirmi a mio agio sicuramente... se magari ero fradicia, bagnata, entrando in un negozio di uno sconosciuto magari mi sentivo un po ' più impacciata... invece così a casa di un amico ovviamente... arrivo... lo saluto, anzi non lo saluto neanche... gli dico "scusa, mi fai andare in bagno?"

S: Perfetto...

$P:$ Sì...

S: Sì.. E per te questo questo, questo modo di agire è giusto? In questa situazione e in questo spazio?

$P$ : Sì giusto si ...

S: Adeguato...

P: Sì... naturale... è una situazione in quel contesto... naturale e tra persone che si conoscono bene...

S: Eh... Se osserviamo il modo in cui hai...scusa.. 
P: Dicevo... con uno sconosciuto mi sarei... mi sarei comportata diversamente e avrei detto delle cose diverse, ovviamente...

S: Ok sì sì vero... bene... allora il modo in cui hai fatto la richiesta il modo in cui ti muovi nel video e gli atteggiamenti che hai assunto, il tono della voce... tutto questo, questi aspetti per questo video ti sembrano naturali o vicino... vicini a come agisci nella vita reale?

$P:$ Si...

S: O c'è qualcosa di diverso...?

P: Sì.. sì... no... direi piuttosto... molto naturale... molto naturali... è un comportamento quotidiano mio spontaneo...

S: Ok... perfetto...

P: Rivedendo... sì...

S: Sì... e c'è qualcosa che faresti in modo diverso?

P: Direi di no

S: No... ok ... e le azioni che hai svolto... queste azioni ti sembrano adatte alla situazione?

$P$ : Sì andare direttamente in bagno di un amica... si

S: Si... brava si ok

P: Di uno sconosciuto no.... ripeto....

S: Sì... in questa situazione... in questa situazione andare direttamente in bagno è una cosa possibile e adatta anche...

P: Non c'è nulla di strano nel senso in quel contesto a casa di qualcuno che conosci bene no... non c'è problema, se io entrassi in un ristorante a chiedere riparo o in un bar... cioè.. dovrei, insomma, dire almeno ... fare una premessa diversa da quella che con $K$.

S: Vero... allora... pensiamo adesso a quello che viene detto, alle parole e alle espressioni che hai scelto... quanto naturali queste parole, queste scelte linguistiche ti sembrano?

P. Si, naturali... c'è ancora il punto vista... naturale.... delle parole e anche della mimica... di gesticolare così... naturali... che farei sì

S: Si

$P:$ Sì sì

S: Non c'è niente che diresti in modo diverso?

$P$ : No che... non so... non mi è saltato nulla agli occhi che mi fa... rivedendomi... mi fa sembrare una cosa... un'altra persona, no...

$S: O k$

P: Quindi ti direi... sì tranquillamente....

S: Allora... le due ultime domande... questi elementi... quello che hai detto... in che misura sono parole ed espressioni che usi nella vita quotidiana?

P: Quanto sono parole che uso...

S: Sì... quanto sono adatte alla situazioni e quanto sono parole che usi veramente nella vita quotidiana? P: Sì... sono parole... sono parole che uso assolutamente nel quotidiano e mi sembrano anche adatte al contesto... a quel momento particolare, alla situazione... all'evento...

S: Ok... allora... l'ultima domanda è se hai altre osservazioni da aggiungere sulla naturalezza di questo video... c'è qualcosa da dire... secondo te.... è molto naturale, un video.... non lo so... vicino alla realtà... $P$ : Sì è vicino e piuttosto aderente alla realtà secondo me molto simile a una situazione non registrata... io credo che noi ci saremmo comportate...

S: Molto simile

P: Sia io che K... sarebbe stato molto simile...

S: Pure K pure K è... sarebbe la stessa?

P: Sì... io credo di sì...

S: Ok.. ecco era questo... 


\section{Anexo 3 - Perguntas e respostas da parte aberta do questionário final}

\section{9 - Riesci a dire quali elementi ti hanno guidato al momento di attribuire il tuo punteggio? Hai ancora altre osservazioni da aggiungere sulla "naturalezza" dei video che hai visto?}

[Você consegue dizer quais elementos te guiaram no momento de atribuir a pontuação? Tem ainda alguma observação que gostaria de acrescentar sobre a "naturalidade" dos vídeos a que assistiu?]

\section{0 - Alcuni dei video che hai visto sono stati registrati da attori professionisti. Riusciresti a dire quali?}

[Alguns dos vídeos aos quais você assistiu foram gravados por atores profissionais. Você saberia dizer quais?]

\section{1 - Quali aspetti ti hanno fatto decidere quali sono $i$ video registrati da attori professioni e quali da "persone comuni"?}

[Quais aspectos te levaram a decidir quais são os vídeos gravados por atores profissionais e quais por "pessoas comuns"?]

\begin{tabular}{|c|c|c|c|c|}
\hline \multirow{2}{*}{ Info. } & \multirow{2}{*}{ Grupo } & \multicolumn{3}{|c|}{ Questionário (parte aberta) } \\
\cline { 3 - 6 } & & pergunta & pergunta & pergunta \\
\hline 1 & 1 & 2 & $\begin{array}{c}\text { I due ragazzi di un video sanno recitare } \\
\text { bene, tutti gli altri sono inguardabili }\end{array}$ \\
\hline 2 & 1 & $\begin{array}{c}\text { ho usato il mio personale "approccio" } \\
\text { all'italiana per valutare la naturalezza } \\
\text { delle situazioni. Una scala di }\end{array}$ & 2,3 & $\begin{array}{c}\text { la posizione rispetto al punto di ripresa. } \\
\text { la voce. forse potrei essere stato } \\
\text { forviato dall'età e dunque dall'approccio } \\
\text { di questi di fronte ad una videoripresa }\end{array}$ \\
\hline 3 & 1 & $\begin{array}{c}\text { Spontaneità e scelta dei dialoghi } \\
\text { l'elemento che mi ha guidato è piu }\end{array}$ & 2,4 & $\begin{array}{c}\text { scelta dei dialoghi, movenze del corpo, } \\
\text { naturalezza }\end{array}$ \\
\hline 4 & 1 & Linguaggio del corpo & 2,4 & La naturalezza nei dialoghi \\
\hline 5 & 1 & La gestualità dei personaggi & 2,4 & Come erano rilassati di fronte alla \\
telecamera
\end{tabular}




\begin{tabular}{|c|c|c|c|c|}
\hline 8 & 1 & Atteggiamento & 2,4 & La spontaneità \\
\hline 9 & 1 & Le mie esperienze & 2,4 & $\begin{array}{l}\text { La naturalezza e scioltezza con la quale } \\
\text { parlano }\end{array}$ \\
\hline 10 & 1 & $\begin{array}{l}\text { La scelta delle parole, il tono e } \\
\text { successivamente la gestualitá }\end{array}$ & 2,4 & $\begin{array}{l}\text { La naturalezza ed il realismo dei } \\
\text { dialoghi }\end{array}$ \\
\hline 11 & 1 & I gesti e le parole & 2,4 & La spontaneità \\
\hline 12 & 1 & $\begin{array}{l}\text { Lo spazio non è mai un problema: } \\
\text { adeguato sempre. La naturalezza delle } \\
\text { situazioni non è "normale". }\end{array}$ & $2,3,4$ & $\begin{array}{c}\text { La dizione, la spontaneità, la capacità di } \\
\text { fare richieste "assurde" in modo } \\
\text { naturale. }\end{array}$ \\
\hline 13 & 1 & $\begin{array}{l}\text { Linguaggio comune, maggior } \\
\text { naturalezza nelle risposte }\end{array}$ & 3,4 & $\begin{array}{l}\text { L'impostazione della voce e la postura } \\
\text { in camera }\end{array}$ \\
\hline 14 & 1 & $\begin{array}{l}\text { Come sono vestiti, come si muovono e } \\
\text { come parlano }\end{array}$ & 2,4 & Il modo di parlare e muoversi \\
\hline 15 & 1 & $\begin{array}{l}\text { La naturalezza dei gesti e del } \\
\text { linguaggio degli attori }\end{array}$ & 2,4 & Il modo di esporre \\
\hline 16 & 1 & $\begin{array}{c}\text { La comunicazione non verbale } \\
\text { sicuramente, ma anche elementi } \\
\text { parafernali come il tono e il ritmo della } \\
\text { voce. }\end{array}$ & 2,4 & $\begin{array}{l}\text { La naturalezza e spontaneità di } \\
\text { entrambi i personaggi e la loro } \\
\text { "credibilità". Se non avessi saputo che } \\
\text { sapevano già cosa dire e fare, avrei } \\
\text { pensato fosse un video autentico. }\end{array}$ \\
\hline 17 & 1 & la verosimilità della situazione & 2,4 & $\begin{array}{l}\text { la credibilità del colloquio soprattutto } \\
\text { nell'interazione più naturale possibile }\end{array}$ \\
\hline 18 & 1 & $\begin{array}{l}\text { disinvoltura, movimenti, modulazione e } \\
\text { tono della voce }\end{array}$ & 2,4 & $\begin{array}{c}\text { Nel n } 2 \text { il ragazzo sembra essere } \\
\text { l'attore, è molto naturale e disinvolto. } \\
\text { Nel n.4 la ragazza, anche lei naturale e } \\
\text { non impostata "come se dovesse } \\
\text { recitare" }\end{array}$ \\
\hline 19 & 1 & $\begin{array}{l}\text { Ho cercato di capire il grado di } \\
\text { familiarità che intercorre fra i due } \\
\text { interlocutori (se sono amici, se sono } \\
\text { conoscenti, oppure se sono perfetti } \\
\text { sconosciuti). Questo determina tutto (o } \\
\text { quasi tutto) secondo me: ciò che fra due } \\
\text { amici può essere normale, fra vicini di } \\
\text { casa può essere sfacciataggine e fra } \\
\text { sconosciuti può essere scortesia e } \\
\text { maleducazione. }\end{array}$ & 1,4 & $\begin{array}{l}\text { Un'apparente maggiore disinvoltura } \\
\text { nell'eloquio e nel tono di voce, più forte } \\
\text { e chiaro - per lo stesso motivo, però, il } \\
\text { personaggio interpretato dalla signora } \\
\text { mora mi risulta esageratamente diretto, } \\
\text { scortese, sfacciato, sbrigativo e, in } \\
\text { definitiva, antipatico (similmente direi } \\
\text { per il ragazzo "romano" in casa, coi } \\
\text { capelli lunghi, che anticipa dei } \\
\text { movimenti prima ancora di aver } \\
\text { ricevuto l'assenso da parte } \\
\text { dell'interlocutrice). Complessivamente, } \\
\text { in una situazione reale si } \\
\text { utilizzerebbero molto delle formule di }\end{array}$ \\
\hline
\end{tabular}




\begin{tabular}{|c|c|c|c|c|}
\hline & & & & $\begin{array}{l}\text { cortesia (soprattutto nel Centro Italia), } \\
\text { veicolate da congiuntivi e condizionali. }\end{array}$ \\
\hline 20 & 1 & $\begin{array}{l}\text { Il fatto che quanto vedevo e sentivo } \\
\text { fosse vicino ad una situazione reale }\end{array}$ & 4 & Li ho percepiti più fluidi \\
\hline 21 & 1 & Spontaneità & 4 & La serenità \\
\hline 22 & 1 & $\begin{array}{l}\text { 1) il tono della voce } 2 \text { ) le parole } \\
\text { utilizzate } 3 \text { ) la credibilità delle richieste, } \\
\text { cioè quanto potrebbero essere } \\
\text { realistiche 4) l'arredamento e gli spazi }\end{array}$ & 4 & il timbro della voce e la gestualità \\
\hline 23 & 1 & $\begin{array}{l}\text { Uso di espressioni gergali,della } \\
\text { gestualità e del linguaggio del corpo }\end{array}$ & 2,4 & $\begin{array}{l}\text { Maggiore aderenza ad un linguaggio } \\
\text { reale (e magari anche gergale)nei gesti } \\
\text { e nelle parole usare }\end{array}$ \\
\hline 24 & 1 & $\begin{array}{l}\text { La spontaneità dei dialoghi mi ha } \\
\text { guidato ad assegnare i punteggi }\end{array}$ & 2 & $\begin{array}{l}\text { La naturalezza dei dialoghi e delle } \\
\text { battute }\end{array}$ \\
\hline 25 & 1 & Le parole usate e la mimica & 4 & $\begin{array}{l}\text { La mimica adeguata alla richiesta. La } \\
\text { "spontaneità" }\end{array}$ \\
\hline 26 & 1 & $\begin{array}{l}\text { La qualità audio ha influito sul giudizio } \\
\text { (credo) }\end{array}$ & 2,4 & $\begin{array}{l}\text { Maggiore immedesimazione con i } \\
\text { personaggi }\end{array}$ \\
\hline 27 & 1 & La naturalezza & 3 & La realtà delle vicende \\
\hline 28 & 1 & Movimenti tono della voce & 2,4 & Spontaneità \\
\hline 29 & 1 & $\begin{array}{l}\text { La spontaneità nella recitazione e la } \\
\text { gestualità (molto naturale) degli attori }\end{array}$ & $1,2,3$ & La spontaneità nella recitazione. \\
\hline 30 & 1 & $\begin{array}{c}\text { L'aderenza a situazioni simili già } \\
\text { vissute }\end{array}$ & 1,4 & $\begin{array}{l}\text { Il tono "naturale" che in realtà non lo è, } \\
\text { nella realtà si è impacciati e confusi }\end{array}$ \\
\hline 31 & 2 & $\begin{array}{l}\text { La scelta del dialetto, la coerenza di ciò } \\
\text { che viene detto rispetto alla situazione }\end{array}$ & 2 & Quelli a cui ho creduto di più \\
\hline 32 & 2 & $\begin{array}{l}\text { "Naturalezza dei gesti e Intonazione } \\
\text { della voce. Prossemica" }\end{array}$ & $2,3,4$ & $\begin{array}{l}\text { Scelta dei tempi di reazione, anche se } \\
\text { nel video } 3 \text { quelli del ragazzo non sono } \\
\text { buoni. Ritmo. Naturalezza rispetto alla } \\
\text { telecamera. Gestualità semplice ma } \\
\text { efficace. Assenza di tensioni inutili. }\end{array}$ \\
\hline 33 & 2 & $\begin{array}{l}\text { Mi ha guidato nel giudizio la } \\
\text { prossemica: spesso accade che gli attori } \\
\text { si "tradiscano", ovvero dicano col corpo } \\
\text { qualcosa che non corrisponde a quello } \\
\text { che dicono verbalmente. E in alcuni }\end{array}$ & 2,3 & $\begin{array}{l}\text { Il rapporto con la camera (spesso i } \\
\text { movimenti di alcuni attori non erano in } \\
\text { favore della stessa); la disinvoltura con } \\
\text { la recitazione, anche se alle volte non è } \\
\text { un fedele indicatore; la lunghezza dei }\end{array}$ \\
\hline
\end{tabular}




\begin{tabular}{|c|c|c|c|c|}
\hline & & $\begin{array}{l}\text { video ho potuto constatare questa } \\
\text { disconnessione tra parola e gesto. }\end{array}$ & & $\begin{array}{l}\text { video, più facile da sostenere da attori } \\
\text { professionisti. }\end{array}$ \\
\hline 34 & 2 & $\begin{array}{l}\text { Ho deciso di non tener conto della } \\
\text { qualità del video o delle riprese e di } \\
\text { cercare di eliminare quel filtro per } \\
\text { concentrarmi sull'attore (professionista } \\
\text { o non). }\end{array}$ & 1,3 & $\begin{array}{l}\text { la ricerca di una gestualità stereotipata, } \\
\text { la postura innaturale }\end{array}$ \\
\hline 35 & 2 & $\begin{array}{l}\text { Spesso la naturalezza è avvantaggiata } \\
\text { (o svantaggiata) dalla scrittura più che } \\
\text { dalla recitazione. }\end{array}$ & 4 & Gestione del corpo e spontaneità \\
\hline 36 & 2 & $\begin{array}{l}\text { Tutto molto costruito a parte alcuni } \\
\text { momenti isolabili in alcuni video. }\end{array}$ & 2 & Più relazione fra le persone \\
\hline 37 & 2 & $\begin{array}{l}\text { un ritmo e un tempo si percepisce } \\
\text { spontaneo se non è pre-costruito. }\end{array}$ & 2,4 & $\begin{array}{l}\text { non ho notato nel } 2 \text { e nel } 4 \text { anticipazioni } \\
\text { nella situazione. }\end{array}$ \\
\hline 38 & 2 & $\begin{array}{l}\text { In generale tutte le situazioni, eccetto } \\
\text { una, mi sono sembrate abbastanza } \\
\text { plausibili. L'elemento più importante } \\
\text { per definire la naturalezza é stato il } \\
\text { linguaggio del corpo in forme che } \\
\text { ritengo "quotidiane" e la capacità di } \\
\text { ascolto e reazione degli attori rispetto ai } \\
\text { comportamenti del partner }\end{array}$ & 2,4 & $\begin{array}{l}\text { Per individuare gli attori professionisti } \\
\text { ho osservato la ricercatezza delle } \\
\text { azioni, l'attenzione per la macchina da } \\
\text { presa, variazioni ritmiche nel parlato; } \\
\text { per le persone comuni, la frontalità alla } \\
\text { macchina da presa, la monotonia nel } \\
\text { parlato, il tempo morto di attesa delle } \\
\text { "battute" del partner }\end{array}$ \\
\hline 39 & 2 & $\begin{array}{l}\text { più la scena pare finta (paradossalmente } \\
\text { "recitata") e più il mio punteggio è } \\
\text { basso }\end{array}$ & 2,4 & $\begin{array}{l}\text { quelli che non mi sembrano essere } \\
\text { attori professionisti non sembravano } \\
\text { esprimersi e muoversi in modo naturale }\end{array}$ \\
\hline 40 & 2 & $\begin{array}{l}\text { Credibilità tra movimento, parola, } \\
\text { azione e soprattutto situazione. Uno } \\
\text { fradicio: a) deve essere fradicio, e poi } \\
\text { non si muove per la casa di un ospite } \\
\text { liberamente. }\end{array}$ & 4 & $\begin{array}{l}\text { La capacità di saper rendere credibile } \\
\text { l'incredibile:una situazione ricostruita, } \\
\text { con microfono non è naturale, l'arte } \\
\text { dell'attore la rende tale. }\end{array}$ \\
\hline 41 & 2 & $\begin{array}{l}\text { Ho cercato di distinguere il livello di } \\
\text { espressività attoriale dal livello di } \\
\text { realismo generale }\end{array}$ & 2 & $\begin{array}{l}\text { ho percepito un'impostazione diversa } \\
\text { nella ricerca del linguaggio }\end{array}$ \\
\hline 42 & 2 & $\begin{array}{l}\text { La verosimiglianza, la scelta delle } \\
\text { parole, la spontaneità e l'eventuale } \\
\text { presenza di battute "telefonate" }\end{array}$ & 2,4 & $\begin{array}{l}\text { L'uso di alcune espressioni e termini, e } \\
\text { una maggiore spontaneità nella voce }\end{array}$ \\
\hline 43 & 2 & $\begin{array}{c}\text { naturalezza personaggi, vicinanza a } \\
\text { vissuto. la naturalezza del parlato } \\
\text { spesso non corrispondeva a naturalezza } \\
\text { del corpo. }\end{array}$ & 2,3 & $\begin{array}{l}\text { in realtà pensavo ci fosse un attore e } \\
\text { una persona non professionista in ogni } \\
\text { video. la mia scelta precedente quindi è } \\
\text { stata basata su } 2 \text { personaggi che mi } \\
\text { sembravano attori per maggiore } \\
\text { organicità }\end{array}$ \\
\hline
\end{tabular}




\begin{tabular}{|c|c|c|c|c|}
\hline 44 & 2 & $\begin{array}{l}\text { Le azioni e le scelte delle parole. Non } \\
\text { ho trovato naturale la richiesta di fare } \\
\text { una doccia appena entrati in casa un po' } \\
\text { per la cosa in sé un po' perché non } \\
\text { sembrava un'amicizia così stretta da } \\
\text { rendere l'azione naturale fra le due } \\
\text { coppie di persone. }\end{array}$ & 2,4 & $\begin{array}{l}\text { Hanno una maggiore scioltezza, il } \\
\text { disagio/sentimento del personaggio è } \\
\text { reale e non forzato. }\end{array}$ \\
\hline 45 & 2 & $\begin{array}{l}\text { Attori sono troppo naturali rispetto a } \\
\text { situazioni strane tipo piombare in casa } \\
\text { di qualcuno bagnati e chiedere di farsi } \\
\text { una doccia }\end{array}$ & 4 & La signora ha parlato in dizione \\
\hline 46 & 2 & $\begin{array}{l}\text { Cercare di isolare gli elementi } \\
\text { azione/parola/spazio invece di rimanere } \\
\text { ancorata ad una percezione d'insieme }\end{array}$ & 2,3 & $\begin{array}{l}\text { Le "persone comuni" sono più } \\
\text { spontanee e credibili anche se } \\
\text { commettono "errori" come accavallarsi } \\
\text { quando parlano e non considerare la } \\
\text { telecamera (c'è una partecipante a cui } \\
\text { non si vede mai la faccia). Hanno anche } \\
\text { fretta di finire, mentre gli attori } \\
\text { allungano la scena anche più del } \\
\text { necessario come se volessero occupare } \\
\text { più spazio di quello che la scena } \\
\text { richiede. }\end{array}$ \\
\hline 47 & 2 & $\begin{array}{l}\text { La quantità di gesti non naturali dati } \\
\text { dall'imbarazzo di dover "recitare", il } \\
\text { tono enfatizzato della voce, l'uso di } \\
\text { stereotipi e la scarsa attenzione ai } \\
\text { dettagli mi hanno fatto dare punteggi } \\
\text { bassi }\end{array}$ & 2 & $\begin{array}{l}\text { I professionisti bravi hanno attenzione } \\
\text { ai dettagli di ciò che accadrebbe in } \\
\text { realtà, nella coppia } 4 \text { la recitazione } \\
\text { traspare soprattutto nella donna, mentre } \\
\text { i non professionisti si appoggiano a } \\
\text { immagini molto vaghe ed esasperano } \\
\text { gesti e toni della voce }\end{array}$ \\
\hline 48 & 2 & Le espressioni usate & 2,3 & $\begin{array}{l}\text { Era visibile la recitazione degli attori } \\
\text { professionisti }\end{array}$ \\
\hline 49 & 2 & La credibilità, naturalezza dei parlanti. & 2,4 & $\begin{array}{l}\text { Ho scelto le coppie che mi sono } \\
\text { sembrate più naturali e meno artificiali } \\
\text { (a volte però sono gli attori i più finti). }\end{array}$ \\
\hline 50 & 2 & $\begin{array}{l}\text { Reazioni e ascolto dell'altro. } \\
\text { Naturalezza dei gesti e delle situazioni. }\end{array}$ & 2,4 & $\begin{array}{l}\text { L'attore è in grado di ricreare la } \\
\text { naturalezza di una determinata } \\
\text { situazione nonostante la macchina da } \\
\text { presa. Questa naturalezza "costruita" è } \\
\text { data da una moltitudine di elementi, tra } \\
\text { cui: ascolto/ricezione, fluidità del } \\
\text { movimento, spontaneità, } \\
\text { immedesimazione... Nei video che } \\
\text { avete proposto, i non professionisti si } \\
\text { riconoscono soprattutto per la } \\
\text { mancanza di "ascolto" fra i personaggi, } \\
\text { che viene chiamata "fase di ricezione" } \\
\text { (in particolare nel video in cui il } \\
\text { ragazzo riccio si accorge di dover }\end{array}$ \\
\hline
\end{tabular}




\begin{tabular}{|c|c|c|c|c|}
\hline & & & & $\begin{array}{l}\text { andare subito a prendere il suo amico). } \\
\text { Complimenti per il vostro lavoro! }\end{array}$ \\
\hline 51 & 2 & $\begin{array}{l}\text { Molti avevano delle gestualità } \\
\text { veramente meccaniche. }\end{array}$ & 2,4 & Naturalezza e voce \\
\hline 52 & 2 & $\begin{array}{l}\text { Ho cercato di attenermi strettamente ai } \\
\text { parametri richiesti dalle domande. Ho } \\
\text { scisso l'aspetto di credibilità "recitativa" } \\
\text { dalla plausibilità della situazione. La } \\
\text { naturalezza viene data quando il } \\
\text { linguaggio del corpo e quello verbale } \\
\text { vanno nella stessa direzione e } \\
\text { non fanno cose differenti ( a meno che } \\
\text { non sia voluto, per esempio è un } \\
\text { atteggiamento inconscio che si assume } \\
\text { quando si mente). }\end{array}$ & 2,4 & $\begin{array}{l}\text { A mio avviso, nei video che ho } \\
\text { segnalato i protagonisti erano "veri" } \\
\text { cioè concreti..E vero che un attore } \\
\text { riproduce la realtà e riproducendo fa sì } \\
\text { che produca un effetto di credibilità. } \\
\text { Differente cosa è l' imitazione. } \\
\text { Qualsiasi imitazione, per quanto fatta } \\
\text { bene, non risulterà originale. In questo } \\
\text { caso diremmo naturale. }\end{array}$ \\
\hline 53 & 2 & $\begin{array}{l}\text { Sicuramente la coppia più naturale } \\
\text { è quella della giovane coppia di amici } \\
\text { che girano in casa. }\end{array}$ & 2,4 & $\begin{array}{l}\text { I non professionisti davanti alla } \\
\text { telecamera "sentono" di dover dare } \\
\text { qualcosa in più alla loro } \\
\text { interpretazione. }\end{array}$ \\
\hline 54 & 2 & $\begin{array}{l}\text { La naturalezza del testo e delle azioni } \\
\text { svolte dagli attori. }\end{array}$ & 2,4 & $\begin{array}{l}\text { A mio parere si vedeva come le persone } \\
\text { comuni pur guadagnando qualcosa in } \\
\text { spontaneità non avessero ben contezza } \\
\text { dello spazio e fossero più "impacciate" } \\
\text { nella recitazione oltre che nella tecnica } \\
\text { come dizione e articolazione delle } \\
\text { battute. }\end{array}$ \\
\hline 55 & 2 & Alcune registrazioni erano poco chiare & 2 & I movimenti \\
\hline 56 & 2 & Doti attoriali & 2,4 & $\begin{array}{l}\text { In positivo, una naturalezza controllata } \\
\text { e supportata da strumenti che si } \\
\text { acquisiscono con lo studio della } \\
\text { recitazione; in negativo, il cosiddetto } \\
\text { "overacting" }\end{array}$ \\
\hline 57 & 2 & $\begin{array}{l}\text { Principalmente ho controllato i } \\
\text { movimenti del corpo, in relazione con } \\
\text { oggetti, spazio e persone. }\end{array}$ & 2,4 & $\begin{array}{l}\text { Il controllo dello spazio in relazione } \\
\text { all'inquadratura e lo sviluppo di } \\
\text { interazione l'altra persona. L'opzione } \\
\text { n4 è probabilmente eseguita da attori } \\
\text { non professionisti eppure superano di } \\
\text { gran lunga le formazioni amatoriali (o } \\
\text { meno) delle altre opzioni. } \\
\text { P.s. qualcuno dica all'attrice } \\
\text { dell'opzione n2 che gli asciugamani } \\
\text { non si tengono in cucina! }\end{array}$ \\
\hline 58 & 2 & $\begin{array}{l}\text { Come si muovevano in relazione l'uno } \\
\text { con l'altro, il modo in cui veniva posta } \\
\text { la domanda. }\end{array}$ & 2 & $\begin{array}{l}\text { La spontaneità e l'organicità nelle } \\
\text { parole e nei movimenti }\end{array}$ \\
\hline
\end{tabular}




\begin{tabular}{|c|c|c|c|c|}
\hline 59 & 2 & $\begin{array}{c}\text { La verosimilita' e la credibilità"dei } \\
\text { protagonisti }\end{array}$ & 2,4 & $\begin{array}{c}\text { Non saprei in effetti se sono attori } \\
\text { professionisti. Nei video indicati trovo } \\
\text { persone piu' credibili. Nei video non } \\
\text { indicati trovo i protagonisti poco } \\
\text { credibili }\end{array}$ \\
\hline 60 & 2 & i gesti e le parole. niente da aggiungere & 1,2 & il parlato \\
\hline
\end{tabular}

